\title{
Tweedeling in perspectief
}

Sdu Uitgevers, Den Haag, 1996 
ISBN Nr. 9039912742 
Wetenschappelijke Raad voor het Regeringsbeleid
Aan de Minister-President

Minister van Algemene Zaken

De heer W. Kok

Postbus 20001

2500 EA 's-Gravenhage

Uw brief

Onderwerp

rapport nr. 50

Tweedeling in perspectief
Ons kenmerk 960430/FB/MN
Kantooradres: Plein 1813, nr. 2

Postbus 20004

2500 EA 's-Gravenhoge

Telefoon 070 - 3564600

Telefax $070-3564685$

18 december 1996

Doorkiesnummer

070-3564471

Hierbij zenden wij u het rapport 'Tweedeling in perspectief'. Dit rapport wordt door de raad op eigen initiatief uitgebracht en heeft het karakter van een sociaal-culturele toekomstverkenning.

In het rapport wordt nagegaan in hoeverre sprake is van 'tweedeling' in onze samenleving en wat op dit punt de vooruitzichten zijn tot circa 2015. Dit gebeurt aan de hand van de ontwikkelingen op een drietal vendelingsdimensies - arbeid, opleiding en inkomen - die het kader vormen waarbinnen de sociale samenhang vorm krijgt. De raad komt tot de bevinding dat, anders dan vaak wordt gedacht, de kansen op een harmonieuze sociaal-culturele ontwikkeling voor de middellange termijn in de jaren negentig zijn toegenomen. De hoofdopgave voor het beleid is nu de vooruitgang die de bevolking als geheel boekt, ook ten goede te laten komen aan laaggeschoolden die de aansluiting op de arbeidsmarkt missen. Het tot stand brengen van meer eenvoudige werkgelegenheid is, gezien het verder toenemend belang van arbeid als integratiekader, de beste manier om tweedeling in een zich verder individualiserende samenleving tegen te gaan.

Volgens de procedure die in de Instellingswet WRR is vastgelegd, ziet de raad graag het bericht van kennisneming door en de bevindingen van de Raad van Ministers tegemoet.

De voorzitter,

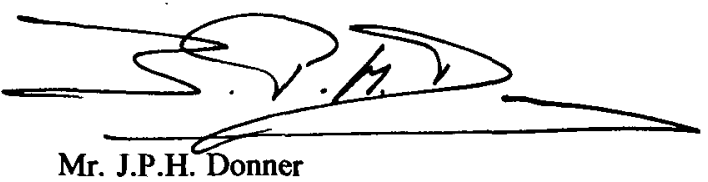

Mr. J.P.H. Donner
De secretaris,

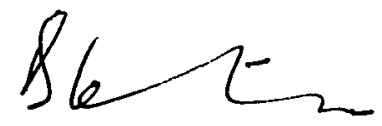

Mr. J.C.F. Bletz 



\section{Inhoudsopgave}

Samenvatting

Ten geleide

I. Tweedeling in Nederland 13

I.I Opvattingen en feiten 13

I.2 Het publieke debat 15

I.3 Wetenschappelijke discussie over verdelingsvraagstukken 19

I.4 Differentiatie en segmentatie: een conceptuele exercitie 23

1.4.I Sociaal relevante onderscheidingen 23

$\begin{array}{ll}\text { I.4.2 Patronen van sociale differentiatie } & 24\end{array}$

\begin{tabular}{lll} 
I.4.3 Sociale segmentatie & 24 \\
\hline & & 24
\end{tabular}

I.4.4 Segmentatie en cohesie 24

I.5 Tweedeling in perspectief 25

2. Veranderingen op drie verdelingsdimensies 29

2.1 Inleiding 29

$\begin{array}{lll}2.2 & \text { Beroep } & 30\end{array}$

2.2.1 Aard en betekenis 30

2.2.2 Toegankelijkheid 33

2.2.3 Scheefheid van de verdeling $\quad 42$

2.2.4 Openheid en mobiliteit 47

2.2.5 Beroep en segmentatie: voorlopige conclusie $\quad 49$

2.3 Onderwijs en opleiding 50

2.3.1 Inleiding 50

2.3.2 Aard en betekenis 51

2.3.3 Toegankelijkheid 56

2.3.4 Scheefheid van de verdeling 59

2.3.5 Openheid en mobiliteit 61

2.3.6 Onderwijs en segmentatie: voorlopige conclusie 64

$2.4 \quad$ Inkomensverdeling 65

2.4.1 Inleiding 65

2.4.2 Aard en betekenis 66

2.4.3 Toegankelijkheid 67

2.4.4 Scheefheid van de verdeling $\quad 69$

$\begin{array}{lll}2.4 .5 & \text { Mobiliteit } & 72 \\ 2.5\end{array}$

2.5 Samenvatting en conclusie 76

3. Over categorale emancipatie $\quad 79$

3.1 Denken in categorieën $\quad 79$

$\begin{array}{lll}3.2 & \text { Vrouwen } & 81\end{array}$

$\begin{array}{lll}3.2 .1 & \text { Arbeidsmarkt } & 81\end{array}$

$\begin{array}{ll}3.2 .2 & \text { Onderwijs } \\ 3.2 .2 .1 & 84\end{array}$

3.2.2.1 Deelname en opleidingsniveau $\quad 84$

$\begin{array}{ll}\text { 3.2.2.2 Opleidingsrichting } & 85\end{array}$

3.2.3 Niet betaalde (zorg-)arbeid 86

$\begin{array}{lll}\mathbf{3} .2 .4 & \text { Inkomen } & 87\end{array}$

3.2.5 De positie van vrouwen tot $2015 \quad 88$

$\begin{array}{lll}3.3 & \text { Allochtonen } & 89\end{array}$

$\begin{array}{lll}\text { 3.3.1 Inleiding } & 89\end{array}$

$\begin{array}{lll}\text { 3.3.2 } & \text { Arbeidsmarkt } & 90\end{array}$

3.3.3 Onderwijs 93

3.3.4 Inkomen 95

$\begin{array}{lll}3.3 .5 & \text { Wonen } & 95\end{array}$ 
3.3.6 De positie van allochtonen tot $2015 \quad 99$

$\begin{array}{lll}3.4 & \text { Ouderen } & 102\end{array}$

$\begin{array}{lll}3.4 .1 & 102\end{array}$

$\begin{array}{lll}3.4 .2 & \text { Arbeidsmarke } & 103\end{array}$

$\begin{array}{ll}3.4 .3 & 104\end{array}$

$\begin{array}{lll}3.4 .4 & 106\end{array}$

$\begin{array}{lll}3.4 .5 & \text { Maatschappelijke participatie } & 106\end{array}$

$\begin{array}{lll}3.4 .6 & \text { De positie van ouderen tot } 2015 & 108\end{array}$

$\begin{array}{lll}3.5 & \text { De positie van de grote steden } & 108\end{array}$

$\begin{array}{lll}3.6 & \text { De gemeenschappelijke factor: laaggeschooldheid } & \text { II2 }\end{array}$

4. Om de kwaliteit van de toekomst $\quad 115$

4.I Over dimensies en groepen; een eerste balans 115

4.2 De 'Seinsverbundenheit des Wissens' 118

$\begin{array}{ll}\text { 4.2.1 De exclusieve en de inclusieve calculus } & 120\end{array}$

$\begin{array}{ll}\text { 4.2.2 De toekomst als sensitizing concept } & 123\end{array}$

$\begin{array}{ll}\text { 4.2.3 Conclusie } & 124\end{array}$

$\begin{array}{lr}4.3 & 125\end{array}$

$\begin{array}{ll}\text { 4.3.I Het beschermingsparadigma } & 125\end{array}$

$\begin{array}{lll}\text { 4.3.2 Van vervreemding naar ontplooiing } & 126\end{array}$

$\begin{array}{lll}\text { 4.3.3 Het participatieparadigma } & 128\end{array}$

$\begin{array}{ll}\text { 4.3.4 Naar een inclusieve arbeidsmarkt en een inclusieve sociale zekerheid } & 129\end{array}$

$\begin{array}{lll}4.3 .5 & \text { Conclusie } & 133\end{array}$

$\begin{array}{ll}4.4 & \text { De emancipatie van talent }\end{array}$

$\begin{array}{ll}\text { 4.4.1 Gelijkwaardigheid en onderwijs } & 134\end{array}$

$\begin{array}{ll}\text { 4.4.2 De emancipatie van de laaggeschoolde } & 138\end{array}$

$\begin{array}{lll}4.4 .3 & \text { Conclusie } & 138\end{array}$

4.5 De sociale samenhang van een geïndividualiseerde samenleving 139

$\begin{array}{lll}\text { 4.5.1 Individualisering en solidariteit } & 140\end{array}$

4.5.2 Individualisering en de ont-categorisering van de samenleving $\quad 142$

4.5.3 Individualisering, de rol van de overheid en de maatschappelijke organisaties $\quad 145$

4.6 Een slotbalans: kansen, gevaren en beleid $\quad 148$

$\begin{array}{lll}\text { 4.6. I Het dieptepunt van de jaren zeventig en tachtig } & 148\end{array}$

$\begin{array}{lll}\text { 4.6.2 Het sociaal-economische dieptepunt voorbij } & 148\end{array}$

$\begin{array}{lll}\text { 4.6.3 Het sociaal-economisch perspectief voor de toekomst: } & \\ & \text { kansen en gevaren voor cohesie } & 149\end{array}$ 


\section{Samenvatting}

Dit rapport gaat over kansen en bedreigingen voor de sociale samenhang in Nederland gedurende de komende twintig jaar. Aanleiding hiertoe vormt de aandacht die begrippen als 'tweedeling' en de eventuele maatschappelijke consequenties hiervan de laatste jaren hebben gekregen in de publieke discussie, het beleid en in wetenschappelijke kring. De uitkomst van dit rapport, dat als een sociaal-culturele toekomstverkenning kan worden beschouwd, is samen te vatten als volgt:

- in de jaren zeventig en tachtig is de samenhang van onze samenleving zwaar op de proef gesteld. Dit kwam doordat het sociaal-economisch kader onvoldoende ruimte bood voor het opvangen van diepgaande sociaal-culturele veranderingen. Thans zijn, anders dan soms wordt gedacht, de kansen op een harmonieuze sociaal-culturele ontwikkeling voor de middellange termijn toegenomen. Dit is vooral te danken aan de te verwachten gunstiger ontwikkeling van het sociaal-economisch kader, met name van de arbeidsmarkt, mede onder invloed van voortzetting van het hierop gerichte regeringsbeleid;

- het vorenstaande sluit echter op zichzelf een toename van maatschappelijke tweedeling niet uit. Met name zou de vooruitgang op gemiddelden ertoe kunnen leiden dat achterblijvers aan de onderkant buiten beschouwing blijven. In zoverre als sprake is van een dergelijk achterblijven, heeft dit veel te maken met het vasthouden aan regelingen en instituties in de verzorgingsstaat die ooit een adequate bescherming boden aan zwakkeren in de maatschappij, maar die bij de huidige maatschappelijke ontwikkelingen averechts zijn gaan werken;

om dit tegen te gaan is een voortgaande aanpassing van beleid nodig aan de nieuwe omstandigheden. Hierbij gaat het vooral om twee voor de onmiddellijke toekomst belangrijke noties, namelijk die van de 'emancipatie van arbeid' en de 'emancipatie van talent', dat wil zeggen het scheppen van meer mogelijkheden voor weinig geschoolde maar maatschappelijk zinvolle arbeid, alsmede het erkennen van menselijke gelijkwaardigheid op verschillende niveaus van het arbeidsbestel;

naar de mate dat met deze emancipaties vooruitgang wordt geboekt, zal blijken dat ook in een zich individualiserende samenleving een hoge mate van sociale samenhang kan blijven bestaan.

De hiervoor weergegeven gedachtengang is in dit rapport uitgewerkt als volgt. In hoofdstuk 1 wordt het begrip 'tweedeling' nader bezien, teneinde een precisering aan te brengen in wetenschappelijke zin. De centrale probleemstelling die hieruit wordt afgeleid, houdt in dat de feiten omtrent tweedeling niet los kunnen worden gezien van de opvattingen hierover. Er bestaat een interactie tussen wat in feite gebeurt en wat hierover wordt gedacht. Een beter zicht op deze interactie is vereist om de notie van tweedeling in perspectief te plaatsen.

In hoofdstuk 2 wordt nagegaan hoe het dan feitelijk met tweedeling in Nederland is gesteld. Dit gebeurt door de ontwikkelingen te analyseren op drie verdelingsdimensies - beroep, opleiding en inkomen. Deze dimensies zijn gekozen omdat zij tezamen het kader vormen waarbinnen de sociale cohesie vorm krijgt. De gedachte hierachter is dat een voorspoedige ontwikkeling op deze dimensies in beginsel ruimte biedt voor een ontwikkeling in de richting van grotere maatschappelijke samenhang. Een minder voorspoedige ontwikkeling zou kunnen betekenen dat maatschappelijke verbanden toenemend op de proef zullen worden gesteld. Voor iedere verdelingsdimensie zijn in hoofdstuk 2 de veranderingen in relevantie, scheefheid, toegankelijkheid en openheid aan de orde gesteld. 
De hoofdconclusie van de desbetreffende analyses is dat de relatief gunstige ontwikkeling die zich op het ogenblik voordoet, na de aanvankelijke achteruitgang van het kader voor een sociaal-cohesieve ontwikkeling in de jaren zeventig en tachtig, nog niet inhoudt dat de kansen op maatschappelijke integratie hiermee over de hele lijn zijn gewaarborgd.

In hoofdstuk 3 wordt deze hoofdconclusie vervolgens geprojecteerd op een drietal groepen die vanouds bekend staan als 'emancipatiecategorieën', namelijk vrouwen, allochtonen en ouderen. Het resultaat van de analyses leidt tot een tweede hoofdconclusie, namelijk dat deze groepen als groep minder relevant zijn geworden voor het beleid. De verschillen binnen al deze groepen zijn inmiddels te groot om ze nog in hun geheel als relevante beleidscategorieën te kunnen beschouwen. Tevens wordt hier (opnieuw) duidelijk dat het, los van geslacht, etniciteit, leeftijd of andere achtergronden, vooral de combinatie is van laaggeschooldheid en uitsluiting van de arbeidsmarkt die de gemeenschappelijke achterstandsfactor vormt. De betekenis van deze bevinding voor het beleid is dat inspanningen die zich richten op de moeilijke positie van laaggeschoold aanbod op de arbeidsmarkt relevanter zijn - en, wat een voordeel is, ook minder discriminatoir behoeven te zijn - dan specifiek categoraal beleid.

In hoofdstuk 4 wordt deze bevinding op een toekomstgerichte wijze verder uitgewerkt. Bij deze uitwerking wordt steeds de vraag gesteld hoe de ontwikkeling van 'feiten' van invloed zal zijn op de 'opvattingen' en hoe veranderde opvattingen tot de ontdekking leiden van andere feiten.

De eerste paragraaf is gewijd aan de contextgebondenheid van begrippen. De discussie over tweedeling en eventueel hieruit resulterende maatschappelijke ontwrichting kan daardoor worden genuanceerd. Gewezen wordt op de problemen die ontstaan in de beoordeling van de werkelijkheid als begrippen die op zichzelf ooit adequaat waren, buiten hun context worden gebruikt. De uiteenlopende beoordeling van eenzelfde werkelijkheid, afhankelijk van de vraag welke feiten in de berekening worden meegenomen, spreekt in dit verband voor zichzelf. Feiten zijn vaak niet eenduidig; of bepaalde feiten en groepen wel of niet in de berekeningen worden meegenomen (de 'inclusieve' dan wel 'exclusieve' calculus) bepaalt mede het begrippenapparaat waarmee de werkelijkheid tegemoet wordt getreden.

Vervolgens wordt onder de noemer 'emancipatie van de arbeid' aangegeven hoe de historische beweging van kwaliteitsverbetering van de arbeid in de toekomst een vervolg kan krijgen, mits allerlei tijdgebonden regelingen die ooit aan deze emancipatie hebben bijgedragen, worden vervangen door nieuwe, die beter aan de veranderde omstandigheden zijn aangepast. Hierbij gaat de aandacht uit naar het wegnemen van belemmeringen voor het verrichten van zinvolle arbeid aan de onderkant van de scholingsladder. De herijking van het sociale stelsel en met name de introductie van het arbeidsparticipatiemotief in de waarborgfunctie van de sociale zekerheid zijn in dit kader van groot belang.

Het wegnemen van dergelijke belemmeringen betekent tevens dat ook de gedachte van 'emancipatie van talent' een plaats in het beleid moet krijgen. Als intellectuele competentie de plaats gaat innemen van afkomst en vermogen als maatschappelijk verdelingsinstrument, kan dit de positie van de laaggeschoolden verder afbreuk doen. Een ongeclausuleerde meritocratie zou derhalve niet bijdragen aan de maatschappelijke samenhang. 'Emancipatie van talent' betekent dat alle talent, ook het kleine, aanspraak kan maken op een plaats in de belangrijkste verdelingsmechanismen van de samenleving. Uitsluiting van de arbeidsmarkt past daar niet bij. Insluiting zou juist betekenen dat op termijn de fundamentele gelijkwaardigheid van mensen wordt erkend, ongeacht criteria als sociale afkomst of intellectuele competentie. 
Overigens zou het doorbreken van een mogelijke identificatie van intellectuele competentie met menselijke waardigheid ook weer meer ruimte creëren voor onderwijs op maat.

Ten slotte wordt de vaststelling dat vormen van categorale emancipatie en solidariteit in een zich verder individualiserende samenleving steeds minder aangrijpingspunten bieden voor beleid, van een toekomstgerichte uitwerking voorzien. Na de ontzuiling in de jaren zeventig en tachtig, kondigen de jaren negentig en de decennia na de eeuwwisseling zich aan als het tijdperk van de ontlaging. Het verdwijnen van traditionele vormen van solidariteit en sociale cohesie behoeft echter geenszins te betekenen dat ook de solidariteit zelf is verdwenen. Naar de mening van de Raad worden weliswaar oude 'voorgegeven' vormen van solidariteit door de individualisering ontkracht, maar dit neemt niet weg dat tegelijkertijd nieuwe vormen van geïndividualiseerde solidariteit worden aangegaan. Terzake wordt op historische voorbeelden hiervan gewezen. In dit kader past bovendien de geleidelijke verschuiving die optreedt in de rol en vormgeving van overheid, markt en maatschappelijk middenveld. Het besef dat individualisering van de solidariteit geen contradictio in terminis is, vormt naar het oordeel van de Raad een belangrijke voorwaarde voor een adequaat sociaal-cultureel beleid in de komende twintig jaar. 


\section{Ten geleide}

Dit rapport is voorbereid door een interne projectgroep van de WRR onder voorzitterschap van prof.dr. H.P.M. Adriaansens, lid van de raad. Van de projectgroep maakten bij de afronding van het project verder deel uit prof.dr. R. Rabbinge, lid van de raad, dr. A.P.N. Nauta, oud-secretaris van de raad, alsmede de stafmedewerkers dr. P. den Hoed, drs. H.C. van Latesteijn, prof.dr. C.W.A.M. van Paridon (projectcoördinator) en drs. D. Scheele.

Het rapport berust mede op een studie van een groep onderzoekers van de Universiteit Utrecht en de Katholieke Universiteit Nijmegen, onder leiding van prof.dr. H.B.G. Ganzeboom en prof.dr. W.C. Ultee. Deze studie verschijnt tegelijkertijd met dit rapport als WRR-voorstudie V96, onder de titel De sociale segmentatie van Nederland in 2015. 


\section{Tweedeling in Nederland}

\section{I.I Opvattingen en feiten}

Over de toekomst van onze samenleving wordt vaak op bezorgde toon gesproken. De vrees blijkt wijd verbreid dat reeds aanwezige vormen van sociale ongelijkheid zullen toenemen, zodat een tweedeling zal ontstaan op tal van maatschappelijke terreinen, van gezondheidszorg tot arbeidsmarkt. Hierbij wordt gewezen op een groeiende kloof tussen de haves en de have-nots 1. Tweedeling, uitsluiting, duale samenleving, outsiders en underclass zijn termen waarmee voor zulke ontwikkelingen wordt gewaarschuwd 2 .

Een onwetende buitenstaander - de spreekwoordelijke 'man van Mars' - zou zich er over verbazen dat in een geavanceerde verzorgingsmaatschappij als de Nederlandse wordt gediscussieerd over tweedeling en mogelijk hieruit voortkomende ontwrichting van de samenleving. Zo wordt in één van de gezondste samenlevingen ter wereld gesproken over een op handen zijnde tweedeling in de gezondheidszorg 3 ; in een qua inkomensverdeling zeer egalitair land wordt gewaarschuwd voor vergroting van de kloof tussen arm en rijk 4; in een land met het meest succesvolle naoorlogse volkshuisvestingsbeleid worden verkrotting en verpaupering van de binnensteden als dreiging gezien 5; in een land met een relatief goed systeem van sociale voorzieningen wordt een samenhang geconstateerd tussen een 'culture of crime' en een 'culture of poverty' 6; het zijn de 'blijvers in de bijstand' die ondanks de groeiende economie de discussie over de sociale zekerheid bepalen ${ }^{7}$; de alarmklok wordt geluid over de hoge werkloosheid, ook al is de arbeidsparticipatie groter dan ooit voorheen 8 .

Zijn dergelijke discussies dan ongerechtvaardigd? Zeker niet. Ook al geven de feiten aan dat soms de proporties uit het oog worden verloren, dan nog ligt er wel een probleem. De kern hiervan ligt echter vooral in de discrepantie tussen de gewenste en de feitelijke ontwikkeling op de genoemde terreinen. De idealen van een humane samenleving, de behoefte aan een rechtvaardiger bestaansminimum zijn nu eenmaal niet steeds verenigbaar met de feiten - zeker niet op individueel niveau. Erkenning van deze onvermijdelijke kloof tussen gewenste en feitelijke ontwikkelingen vormt het uitgangspunt van waaruit in

'] OESO, The OECD Jobs strategy; technology, productivity and job creation; vol. I, OESO, Parijs, 1996; OESO, The jobs study. Evidence and Explanotions; OESO, Parijs, 1994.

2] De ondere kant van Nederland; Tweede Kamer 1995//996, 245/5, nrs. 1-2; en A.J.F Köbben en J.J. Godschalk, Een tweedeling van de samenleving?; OSA Voorstudie nr. 10, 's-Gravenhage, 1985.

3] Titel van een symposium op II oktober 1995 in de Willem Arntsz Stichting, waarvan het Verslag op 6 maart 1996 officieel is aangeboden aan de minister Borst van WWS.

4] G. Engbersen, R. van der Veen, met een voorwoord van C.J.M. Schuyt, Moderne Armoede: overleven op een sociool minimum: een onderzoek onder 120 Rotterdamse huishoudens; Leiden, Stenfert Kroese, 1987.

5] P.T.M. Tesser e.a., Ropportoge minderheden; concentrotie en segregotie; Rijswijk, SCP, 1995; J. Burgers en G. Engbersen, 'De wrok van Spangen: opkomst en neergang van een arbeidersbuurt'; Psychologie en Mootschappij, jrg. 18, nr. 4. blz. 292-303; W. Albeda e.a, in: Rotterdam ongedeeld noor 2006, een sociaaleconomische opgove; Rotterdam, 1993.

6] R.W. Jongman, F. Weerman en L. Kroes, 'Maatschappelijke tweedeling en criminaliteit'; Tijdschrift voor Criminologie, 33e jrg. nr. I, blz. 29-4I; C.J.M. Schuyt, Tegendroodse werkingen. Sociologische opstellen over onvoorziene gevolgen van verzorging en verzekering. Om de redding van de verzorgingsstaot; Amsterdam, Amsterdam University Press, 1995, hfst. 10: 'De omweg van onverschilligheid: de jeugderiminaliteit nader verklaard'.

] M. van der Aalst en M. Peters, Harde kern in de bijstond; Ministerie van Sociale Zaken en Werkgelegenheid, 's-Gravenhage, Vuga, 1991.

8] Sociale Noto; Tweede Kamer 1996/1997, 25002. 
dit rapport tweedeling, met name in de toekomst, wordt onderzocht. Natuurlijk kent ook deze benadering haar beperkingen, waarover straks meer.

Dit rapport beoogt de maatschappelijke zorg over tweedeling en eventueel hieruit resulterende ontwrichting niet te ontkennen, maar deze wel in perspectief te plaatsen. Het doet dit door zowel de feitelijke veranderingen weer te geven die zich op een aantal essentiële dimensies van verdeling en sociale samenhang hebben afgespeeld, als ook de veranderende opvattingen over

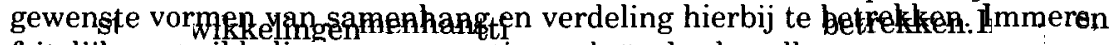
feitelijke ontwikkelingen en opvattingen beïnvloeden elkaar over en weer, en zijn beide, afzonderlijk èn in onderlinge relatie, bok aan voertdurende verandering onderhevig. Een oordeel over de vraag of maatschappelijke tweedeling de sociale samenhang in Nederland in de toekomst onder grotere druk zal zetten, mag hier niet aan voorbij gaan en kan zich derhalve niet beperken tot de extrapolatie van korte-nettotermijnontwikkelingen in het licht van de probleemdefinities van vandaag. Of en hoe die probleemdefinities aan verandering onderhevig zijn en wat het effect hiervan weer zal zijn op de eerder gemeten trends en ontwikkelingen, moet evenzeer worden bekeken. De ervaring leert dat juist op het terrein van sociaal-culturele veranderingen feitelijke ontwikkelingen hand in hand gaan met ontwikkelingen in opvattingen, met andere probleemdefinities en met nieuwe ideologie. Sociale arrangementen die thans als bedreiging worden gezien, vormden eens de basis voor het functioneren van de samenleving. Dezelfde arrangementen die in de jaren vijftig vrouwen 'beschermden' tegen arbeid en hen vrijstelden voor zorg en opvoeding, werden vanaf de jaren zeventig gehekeld als vrouwendiscriminatie. Door een belangrijk deel van onze bevolking werd een verwerpelijk systeem als de 'apartheid' nog tot het midden van deze eeuw beschouwd als passende vorm van christelijke naastenliefde en 'bespreekbare' vorm van voogdijschap 9. In 1978 was het de liberale fractieleider in de Tweede Kamer die meende dat een stijging van de werkloosheid tot boven de $\mathbf{1 5 0 . 0 0 0 ~ h e t ~ e i n d e ~}$ zou betekenen van de sociale cohesie in Nederland. Zulke uiteenlopende factoren - veranderende attitudes, definities en ideologie - mogen in een sociaalculturele toekomstverkenning niet buiten beschouwing worden gelaten.

Rekening houden met voornoemde interactie van opvattingen en feitelijke ontwikkelingen maakt de verkenning uiteraard niet eenvoudiger. Zij krijgt iets van kleiduivenschieten vanuit een roller coaster: over de baan van de kleiduif valt iets verstandigs te zeggen, de bewegingen van de roller coaster zijn al een stuk moeilijker te voorzien, en over hun onderlinge relatie bestaat helemaal weinig houvast. In het geval van deze sociaal-culturele toekomstverkenning kan er over de ontwikkelingen op de belangrijkste verdelingsdimensies gedegen materiaal worden aangedragen; over de ontwikkeling van wensen, opvattingen en uitgangspunten die aan de basis van probleemdefinities liggen, zijn al weer veel minder gegevens beschikbaar, terwijl er over de interactie van beide nauwelijks wetenschappelijke houvast bestaat. Toch zal een beschouwingsperspectief voor de langere termijn, wil het voor toekomstig handelen relevant zijn, hier antwoorden moeten zoeken en kan niet worden volstaan met simplificaties als 'wel of geen tweedeling', 'wel of geen ontwrichting'.

In dit rapport worden antwoorden gezocht door trends en ontwikkelingen op de drie belangrijkste maatschappelijke verdelingsdimensies - beroep, onderwijs, inkomen - in kaart te brengen op basis van 'best available knowledge' en de voorziene ontwikkelingen in een theoretisch-interpretatief kader te plaatsen teneinde zo discrepanties tussen feitelijke en wenselijke ontwikkelingen 
aan het licht te brengen. Hierbij gaat het erom ontwikkelingen die ook bij relatief gunstige economische omstandigheden voor maatschappelijke spanningen kunnen zorgen, te confronteren met veranderende probleemdefinities en met zich voorzichtig aftekenende wijzigingen in opvattingen en ideologie. Op deze manier hoopt de Raad bij te dragen tot kennisvermeerdering op twee punten: in de eerste plaats met welke randvoorwaarden voor de sociale samenhang van de toekomst in ieder geval rekening moet worden gehouden; in de tweede plaats waar, wanneer en in welke mate welke gevaren de maatschappelijke samenhang zouden kunnen bedreigen.

In het vervolg van dit hoofdstuk wordt eerst het belang van de thematiek gedocumenteerd (par. 1.2); dan wordt aangegeven hoe vanuit verschillende disciplines die thematiek op uiteenlopende wijzen wordt benaderd (par. 1.3); vervolgens wordt de thematiek van tweedeling en maatschappelijke ontwrichting in conceptuele zin verduidelijkt (par. 1.4). Het hoofdstuk wordt afgesloten met een probleemstelling en een leeswijzer voor het rapport.

\section{I.2 Het publieke debat}

In de notitie Bouwstenen voor het Kennisdebat (1996) van het Ministerie van Onderwijs, Cultuur en Wetenschappen staat onder het hoofdje 'Tweedeling in de maatschappij' het volgende:

Dit onderwerp is spontaan en vrijwel direct door alle groepen genoemd als een van de grootste veranderingen die men verwacht voor 2010. Er wordt opgemerkt dat die tweedeling zich weliswaar nu al begint af te tekenen in de samenleving, maar dat de afstand, de kloof tussen een 'bovenlaag' en 'onderlaag' alleen maar zal toenemen. Een van de redenen hiervoor is dat beide groepen elkaar steeds minder kennen, elkaar minder ontmoeten en daardoor steeds minder op de hoogte zijn van en begrip hebben voor elkaars situatie. Ook geografisch verwacht men meer gettovorming: aparte woonwijken met concentraties van de 'onderlaag'. Men verwacht ook dat de onderlaag een grotere omvang zal hebben dan nu het geval is. ${ }^{10}$

De consensus die uit dit citaat spreekt over de onvermijdelijkheid van een maatschappelijke tweedeling - in de toekomst meer nog dan thans - vormt een belangrijk sociaal feit. Deze consensus is geleidelijk ontstaan. De stagnerende economische ontwikkeling na 1973, de steeds verder oplopende werkloosheid en de waarneming dat de verzorgingsstaat niet bij machte bleek de veronderstelde bescherming te bieden, kunnen als aandrijvers worden beschouwd voor de verandering van vooruitgangsoptimisme in cultuurpessimisme en van een breed, haast vanzelfsprekend crisisbesef ${ }^{11}$.

Het besef van sociale en culturele verwording, van het dreigend verlies aan maatschappelijke samenhang is door verantwoordelijke politici in de afgelopen twintig jaar krachtig naar voren gebracht. In 1975 beet vice-premier Van Agt het spits af met zijn oproep tot een 'ethisch reveil'. Aanvankelijk beperkte die oproep zich tot gedrag op het gebied van seksualiteit, maar in 1976 verbreedde Van Agt dit tot een geestelijk reveil.

Er is zo een verschraling van intermenselijke solidariteit. Het kan wel waar zijn dat men dat kan afdoen met de opmerking: dit is het zoveelste bewijs van nostalgie. Waar zijn de grote groepen mensen gebleven die bereid waren en er zoveel goeds mee deden, zonder professionalisering zich in te zetten voor gezondheidszorg,

10] Zie Ministerie van Onderwijs, Cultuur en Wetenschappen, Bouwstenen voor het Kennisdebat; Zoetermeer, 1996.

'] J.A.A. van Doorn en C.J.M. Schuyt, De stognerende verzorgingsstoot; jaarboek 1978 van Beleid en Maatschappij. Meppel/Amsterdam, Boom, 1978. 
kinderbescherming en reclassering? Dit is een symptoom van wat aan de hand is met onze maatschappij. ${ }^{12}$

Het is een thema dat in de daaropvolgende jaren regelmatig terugkeerde en de morele tekorten van de burgers in de verzorgingsstaat accentueerde.

De kritiek op de moderne maatschappij die in Nederland gehoord werd, stond niet op zichzelf. Ze maakte deel uit van een stroom van maatschappijkritiek, die met name in de Anglo-Amerikaanse wereld een brede bedding vond. Ze werd daar uitgedragen door spraakmakende (neo-)conservatieve politici, intellectuelen, en instellingen zoals de Heritage Foundation (1973) en de Moral Majority (1979) ${ }^{13}$. Drie factoren van het kwaad werden in die stroom van kritiek aangewezen. Het waren:

- $\quad$ een te grote overheidsbureaucratie, die een te zware last legde op het bedrijfsleven;

- een onderklasse bestaande uit mensen die langdurig afhankelijk waren van uitkeringen en mede daardoor ook het werken waren ontwend; en

een legitimiteitscrisis met als symptomen stadsoproeren, etnische conflicten, belastingfraude en misbruik van sociale regelingen ${ }^{14}$.

Deze drie boosdoeners stonden ook in het Nederlandse publieke debat centraal. Bureaucratiekritiek vormde de leidraad in bekende artikelen en rapporten over regelverdichting, marges van overheidsbeleid, 'overvraging van beleid' en 'illusie van de democratische staat' 15 . Volgens sommigen was de langdurige werkloosheid de voorbode van het ontstaan van een - vooral stedelijke - onderklasse; volgens anderen kon men dat zo niet zeggen ${ }^{16}$. En ten slotte toonde de regering zich bezorgd over de mogelijke toename van etnische conflicten, 'probleemcumulatiegebieden', misbruik van sociale wetten en 'afnemende sociale controle' 17.

Het duurde wellicht langer dan in andere landen voordat in Nederland een besef van crisis ontstond. Zo was de 'Dutch disease' in de Anglo-Amerikaanse media een geliefkoosde term voor een patiënt die ziek is maar dat zelf niet in de gaten heeft, omdat zijn thermometer niet klopt; belangrijke signalen van ziekte werden niet waargenomen omdat zij buiten het officiële denkkader en sociaal-economische model vielen ${ }^{18}$. Maar toen dat besef eenmaal was doorgebroken, ging het ook snel en sprak oud-premier Lubbers van een - aanmerkelijk somberder - nieuwe consensus. Die somberheid betrof meer nog dan het heden, de verwachtingen voor de toekomst.

12] In een lezing voor de reformatorische studentenvereniging SSR in Leiden. Citaat afkomstig uit: Jan Tromp en Paul Witteman, Voor de duvel niet bang; mr. Dries van Agt, van weerzin tot wellust: Haarlem, De Haan, vijfde druk, 1980, blz. 24-27. 'Geestelijk reveil' dateert uit zijn inleiding bij een presentatie in 1976 van de gecombineerde lijst van KVP, ARP en CHU voor de verkiezingen van 1977.

13] Peter Steinfels, The neoconservatives, the men who are changing America's politics; New York, Simon and Schuster, 1979.

14] David M. Ricci, The tronsformation of American politics, the new Washington and the rise of think thanks; New Haven/London, Yale University Press. 1993, blz. 155-160.

15] Slechts enkele voorbeelden uit vele: Brief van de Minister-President van 31 januari 1983 over regeldichtheid en instelling van dereguleringscommissies; Tweede Kamer 1982/1983, 17555, nr. 5I; J.A.A. Van Doorn, 'De overvraging van beleid'; Beleid en Maotschappij, februari 1980, blz. 39-49; L.A. Geelhoed, 'De plaats van de overheid'; Planning en beleid; WRR, Voorstudies en achtergronden nr. 43, 's-Gravenhage, Staatsuitgeverij, 1984; P. Kalma, De illusie van de democratische staat; Deventer, WBS, 1982.

16] H. Kroft e.a., Een tijd zonder werk, een onderzoek naar de belevingswereld van langdurig werklozen; 's-Gravenhage, Sdu Uitgeverij, 1989.

17] Vgl. Regeerakkoord Kabinet-Lubbers in 1982 en de oprichting van de Commissie Kleine Criminaliteit (commissie-Roethof) in 1983.

18] Maatstaven voor het meten van succes en falen van het economisch beleid zouden verkeerd zijn gekozen. Zie o.m hierover W. Driehuis, en A. van der Zwan, De voorbereiding van het economisch beleid kritisch bezien; Leiden, Stenfert Kroese, 1978. 
'Nederland veranderde in de acht jaren tussen 1976 en 1984 van een betrekkelijk welvarend land tot een land met grote zorgen voor de toekomst', zo vat de Winkler Prins Encyclopedie deze ontwikkelingen samen ${ }^{19}$. De economie stagneerde. Al naar gelang een deel van de WAO-ers en van hen die 'slechts' deeltijdwerk zochten, wel of niet werd meegeteld, varieerde het geschatte aantal werklozen tussen 400.000 en 800.000 20. Het kon dan ook niet uitblijven dat gewezen werd op gevaren van maatschappelijke tweedeling. In 1984, ten tijde van het eerste kabinet-Lubbers, was het PvdA-fractieleider Den Uyl die bij de Algemene Beschouwingen in de Tweede Kamer de sociale verhoudingen besprak in termen van tweedeling. De volgende zinnen hebben veel aandacht getrokken:

Steeds diepere kloven tekenen zich af, tussen werkenden en hen die van het arbeidsproces zijn uitgesloten. Tussen hen, die uitzicht hebben op inkomensverbetering en hen die in koopkracht achteruit gaan. Tussen degenen, die kansen hebben om deel te nemen aan nieuwe ontwikkelingen in techniek en economie en hen voor wie de poort naar de toekomst gesloten lijkt. ${ }^{21}$

De typering van de Nederlandse samenleving in termen van tweedeling riep in die dagen het nodige verzet op, evenals de introductie van een term als armoede, waar men in de jaren zeventig gewoon was te spreken over de problemen van minima en 'echte minima'. De kritiek kwam niet slechts van intellectuele zijde, ook minister-president Lubbers kapittelde Den Uyl in de Tweede Kamer voor het gebruik van het woord tweedeling. In zijn verdediging in het parlement, verwees Den Uyl naar een kort daarvoor gepubliceerde nota van de minister van Sociale Zaken en Werkgelegenheid, waarin onomwonden werd gesproken over een maatschappelijke tweedeling ${ }^{22}$. Het taboe op de nieuwe aanduiding was, zo zei hij, al door het kabinet zelf doorbroken en de tweedeling zou in de komende jaren ook niet meer kunnen worden ontkend ${ }^{23}$.

Dat dit inderdaad zo was, bleek daarna wel uit lezingen van Lubbers zelf over de Nederlandse verzorgingsconstellatie. Het centrale thema daarvan was maatschappelijke desintegratie en atomisering, maar ook de tweedelingsnotie kwam erin tot uiting. Zo stelde de premier in een lezing over sociale vernieuwing dat een andere manier van denken over de verzorgingsstaat nodig was geworden omdat de samenleving op een aantal punten was geatomiseerd. De openingsalinea eindigt aldus:

\footnotetext{
Allerlei verbanden zijn minder van betekenis geworden en ook dat veroorzaakt problemen. De sterken redden zich wel, maar de wat zwakker geplaatsten, degenen in achterstandsposities, worden in een grotere achterstand gedwongen. En er is geen vanzelfsprekend verband meer om dat op te vangen. Tot er een grens is bereikt die ons verplicht solidair en met elkaar bezig te zijn. ${ }^{24}$
}

19] J.C. Mulder, in hoofdstuk 'Nederland'; in: Winkler Prins Encyclopedisch Supplement 1984; Amsterdam, Elsevier, 1984, blz. 307.

$\left.{ }^{20}\right]$ De officiële Arbeidskrachtentelling (AKT) sloor twee groepen vit van telling: zij die niet waren ingeschreven bij een Arbeidsbureau en zij die 'slechts' een baan zochten voor minder dan 20 uur p.w. Zie K. Vijlbrief, 'Werkloosheidscijfers'; Beleid en Maatschappij, 1986, nov-dec, blz. 326-328; voorts F.A.J. van den Bosch en C. Petersen, Aspecten van ziekte en arbeidsongeschiktheid in het stelsel van sociale zekerheid; proefschrift Erasmus Universiteit, 1983.

21] J.M. den Uyl, 'Na de Tweedeling'; in: J.M. den Uyl, de toekomst onder ogen, beschouwingen over socidisme, economie en economi sche politiek; Amsterdam, Bert Bakker, 1986, blz. 165.

22] O.a. door W.A. Arts, J.A.A. Van Doorn, en J. Toirkens; vgl. W.A. Arts, 'Van oude en nieuwe armoede, sociale ongelijkheid in een stagnerende verzorgingsmaatschappij'; ESB, jrg. 69, 7-11-1984.

23] J.M. den Uyl, op. cit., blz. 165.

24] 'Sociale vernieuwing als paraplu', rede gehouden op congres van VNG, 22 maart, 1990; in: Samen onderweg; over democratie, christendom en somenleving, economie en internationale vraagstukken; door A. Joustra en $E$. van Venetië (red.), Utrecht. Het Spectrum, 1991, blz. 91. 
Zowel de rede die bekend is geworden onder de naam 'De overbelaste democratie' als de lezing 'Rechtsstaat en samenleving: opnieuw een sociale kwestie', in de pers bekend geworden onder de naam Nederland is ziek, zorgden eertijds voor veel opschudding ${ }^{25}$. Over maatschappelijke desintegratie merkte de toenmalige premier in laatstgenoemde lezing op:

dat onze welvaartsstaat tal van regelingen en voorzieningen kent, maar er onvoldoende in slaagt te voorkomen dat mensen die op deze regelingen aangewezen raken er in feite als het ware in opgesloten worden, respectievelijk onvoldoende geïntegreerd worden in de samenleving.

En aan het slot van dezelfde lezing vatte hij de problematiek aldus samen:

We hebben te maken met de paradoxale situatie dat in de afgelopen twintig à dertig jaar anomie (het negeren van gedragsnormen) en 'Normenflut' zijn gegroeid. Het ene verschijnsel staat niet los van het andere: juist de erosie van processen in de samenleving, waardoor mensen aan gedragsnormen werden herinnerd, en het wegvallen van sociale verbanden, vergrootten het beroep op de overheid om met normen het gat te vullen of zelfs meer te presteren dan die voorheen informele normering had opgeleverd. 26

Zoals bekend, stond dit thema ook centraal in lezingen van de minister van Justitie Hirsch Ballin. Een bekende rede over het publieke ongenoegen en in het bijzonder 'verloedering van het publiek domein' begon aldus:

Het gaat niet goed met Nederland, met de landen in de Westerse wereld. Criminaliteitscijfers stemmen weinig vreugdevol. Het minderhedenvraagstuk begint scherpere trekken te vertonen. De overheid rent rekenend achter de calculerende burger aan. De moeite die de Duitse overheid heeft om de verwende Westeuropeanen wat welvaart te laten leveren voor hun verwante buren, die plotseling aan dezelfde tafel zitten, spreekt - ook in onze richting - boekdelen. Voeg daarbij de offers die ook het milieubeleid nog van ons zal gaan vergen, en er is alle reden tot zorg. ${ }^{27}$

Andere ministers, onder wie de minister voor Ontwikkelingssamenwerking Pronk en de minister van Onderwijs en Wetenschappen Ritzen, vroegen in dezelfde periode eveneens aandacht voor vraagstukken van solidariteit en voor wat laatstgenoemde aanduidde als het wegvallen van zingeving van het bestaan als gevolg van maatschappelijk desintegratie' 28 .

Ten slotte heeft ook minister-president Kok het beeld van een dreigende maatschappelijke tweedeling naar voren gehaald. In de 'marathon'-aanloop naar de verkiezingen van 1994 kwam dit goed tot uitdrukking in zijn Tilburgse rede 'Werkloosheid is geen natuurgegeven' en daarvoor in zijn reactie op het rapport Niemand aan de kant van de commissie-Wolfson, die in opdracht van de PvdA de toekomst van de verzorgingsstaat had onderzocht 29. Dit was ten tijde van zijn vice-premierschap. Maar ook tijdens zijn termijn als premier is de thematiek van maatschappelijke tweedeling en ontwrichting als rechtvaardiging voor voorgenomen of nagelaten beleid aan de orde gekomen.

25] Rede Lubbers, voorjaar 1978, in Joustra en Van Venetië, op. cit. blz. 64-74.

26] Ibid.

27] E.M.H. Hirsch Ballin, 'Het publieke ongenoegen'; rede gehouden op 18 september 1992 in de Balie te Amsterdam, opgenomen in: E.M.H. Hirsch Bailin, In Ernst, oriëntaties voor beleid; 's-Gravenhage, Sdu Uitgeverij, 1994, blz. 52. Zie voor 'verloedering publiek domein' tevens de rede 'De relativering voorbij', februari 1992, blz. 57.

28] 'Waar is de moraal in het klaslokaal?'; interview met minister Ritzen, Trouw, 4 april 1992.

${ }^{29}$ ] 'Als het nu niet lukt is niets meer veilig'; interview met W. Kok, n.a.v. van het verschijnen van het PvdA-rapport 'Niemand aan de kant' (rapport-Wolfson); De Volkskront, 18 januari 1992. 
Een bekend voorbeeld vormt de Den Uyl-lezing Wij laten niemand los ${ }^{30}$. In een toespraak in 1995 te Brussel verwoordde de premier de sociale thema's voor de landen van Europa aldus:

Economische en sociale ongelijkheid leiden tot tweedelingen, tot tegenstellingen die steeds schrijnender worden. Het is een grote uitdaging om de dreigende uitsluiting van mensen van hun rechtvaardig aandeel in welvaart, sociale zekerheid, werk en ontplooiing te voorkomen. Uitsluiting van kansen op eigen inkomen en werkelijk burgerschap bedreigt de stabiliteit en de kwaliteit van de samenleving, zowel in het noorden als het zuiden, in afzonderlijke landen en in grote steden. ${ }^{31}$

Kortom: het valt niet te ontkennen dat tweedeling, in betrekkelijk korte tijd, een vanzelfsprekend thema op de politieke agenda is geworden. Nadat het onderwerp aanvankelijk op grote weerstanden stuitte, is het in een periode van ruim tien jaar deel gaan uitmaken van het officiële vocabulaire. De aanduidingen van de sociale problemen bleken veelal ook op instemming te kunnen rekenen. Telkens werden echter ook relativerende opmerkingen bij de constateringen geplaatst, zoals na de bekende rede van de Koningin onder de titel 'Is de maatschappij in ontbinding', gehouden op 5 mei $1995{ }^{32}$.

Wat verder opvalt in de genoemde beschouwingen, is dat zowel bedreigingen voor het maatschappelijk verband van binnenuit als van buitenaf worden ontwaard. 'Endogeen' zijn het vooral de toekomstdreigingen die in de vorm van voortgaande secularisering, individualisering en atomisering worden waargenomen. Hierdoor zou de solidariteit tussen en binnen bevolkingsgroepen afnemen, zou een mentaliteit van 'ieder voor zich' ontstaan, die bovendien weer aanleiding geeft tot hedonisme, vertrossing en culturele vervlakking in het algemeen. Dit zou niet alleen het weefsel van de maatschappelijke verhoudingen aantasten, maar er bovendien toe bijdragen dat er steeds minder maatschappelijk verweer bestaat tegen de opkomst van extreme ideologie.

Hiernaast kent het debat ook vele 'exogene' toekomstdreigingen. Het gaat dan om ontwikkelingen die vooral economisch en demografisch van aard zijn: globalisering van de economie en de veranderende rol van de nationale overheid, de 'overwinning' van de 'neo-liberale' markteconomie op de 'sociaal-democratische' planeconomie, de technologische ontwikkeling en kennisintensivering, en ten slotte de vergrijzing, de ontgroening en de toenemende immigratie. In het politieke debat overheerst de gedachte dat deze exogene ontwikkelingen de situatie van maatschappelijke ontwrichting en tweedeling zullen verergeren. Soms wel gehoorde defensieve 'beleidssuggesties', variërend van het economisch protectionisme voor het fort Europa via actieve bevolkingspolitiek tot aansporingen met betrekking tot de restrictieve opname van buitenlanders, knopen hierbij aan.

\section{I.3 Wetenschappelijke discussie over verdelingsvraagstukken}

Verdelingsvraagstukken behoren tot de kern van menige sociaal-wetenschappelijke discipline. Het is dus geen wonder dat de maatschappijwetenschappen zich de laatste jaren hebben geroerd op het terrein van tweedeling en maatschappelijke ontwrichting. De studie van sociale gelijkheid en ongelijkheid, van de determinanten van de maatschappelijke orde en organisatie, vormt vanouds het kerngebied van de sociologie. Dit kerngebied was langdurig ingebed in een nu geleidelijk achterhaalde strijd tussen functionalisten en marxisten.

30] W. Kok, Den Uyl-lezing, Amsterdam, De Balie, II december 1995.

31] Lezing L.g.v. 100-jarig bestaan van het Algemeen Nederlands Verbond in Brussel, 5 april 1995.

32] Over de vraag: 'Is de maatschappij in ontbinding?' publiceerde NRC-Handelsblad commentaren van A.C. Zijderveld, Siep Stuurman, en N. Wilterdink; zie NRC-Handelsblad, Opiniepagina, 10 mei 1995. 
De functionalisten legden de oorsprong van sociale ongelijkheid en maatschappelijke orde in 'culturele' opvattingen (waarden, normen, ideeën), de marxisten in 'materiële' productieverhoudingen. Over de interactie van cultureel en materieel hadden beide stromingen hun eigen opvattingen. Het moderne sociale stratificatie- en mobiliteitsonderzoek gaat grotendeels aan deze tegenstelling voorbij. Het biedt inmiddels een goed zicht op tal van determinanten van sociale ongelijkheid, hun onderlinge verschuivingen en ook is er - hoe voorlopig ook - enige indicatie op het vlak van internationale vergelijking en langetermijnprocessen. In het afgelopen decennium is er bovendien een Nederlandse variant van de overwegend van Amerikaanse bodem stammende 'underclass'-studies opgekomen. Door dergelijk sociologisch en cultureel antropologisch onderzoek is veel bekend geworden over de leefwereld van langdurig werklozen en van de zogeheten 'blijvers in de bijstand'. Ook is toenemend aandacht geschonken aan de dynamiek van het informele circuit (de informaliteit) en is, bijvoorbeeld dankzij studies naar de positie van illegalen, meer zicht ontstaan op dat gedeelte van de samenleving dat lange tijd in hoge mate 'ongekend' was gebleven. Kenmerkend voor het sociologisch onderzoek is dat de teneur van onderzoekingen en conclusies nogal uiteenloopt. Het longitudinale, op uitgebreide datasets geënte onderzoek van een aantal belangrijke verdelingsdimensies laat over het algemeen een historische beweging zien naar grotere gelijkheid in opleiding, inkomen, arbeids- en woonsituatie ${ }^{33}$, terwijl de meer antropologisch getinte in-depth studies vrijwel steeds een waarschuwende toon aanslaan 34 . Opnieuw zegt dit minder over de mate waarin één van beide soorten studies het bij het rechte eind heeft, dan over het gegeven dat in de eerste soort studies vooral de 'feitelijke' ontwikkelingen worden geaccentueerd en in de tweede soort juist veel ruimte bestaat voor de confrontatie van die ontwikkelingen met veranderende wensen, perspectieven, opvattingen en ideologieën.

In de economie kan op goede gronden eenzelfde onderscheid worden gemaakt. Ook daar bestaan beide typen van studies. In de ene soort worden feitelijke ontwikkelingen van de inkomensverdeling over een groot aantal jaren nagelopen. Klassiek voorbeeld hiervan is de aandacht die is geschonken aan de ontwikkelingen op het vlak van de inkomensverdeling. Bekend zijn de studies van Pen en Tinbergen ${ }^{35}$, waarin op basis van een twintigtal indicatoren werd geconcludeerd dat de inkomensverdeling in Nederland tussen 1938 en 1972 minder scheef is geworden ${ }^{36}$. Het sociaal-economisch beleid vanaf de jaren vijftig geldt als de belangrijkste factor achter de herverdeling ${ }^{37}$.

Naast deze onderzoekingen waarin ontwikkelingen in de inkomensverdeling over vele jaren worden behandeld en grote datasets worden gebruikt ${ }^{38}$, zijn

33] De sociale segmentatie van Nederland in 2015; door H.B.G. Ganzeboom en W.C. Ultee (red.). WRR, Voorstudies en achtergronden nr. 96, 's-Gravenhage, Sdu Uitgevers, 1997.

34] Zie o.m. Arm Nederland. Het eerste jaarrapport armoede en sociale vitsluiting; door G. Engbersen, J.C. Vrooman en E. Snel (red.), 's-Gravenhage, Vuga, 1996; Th.J Roelandt, Verscheidenheid in ongelijkheid. Een studie noor etnische stratificatie en onderklassevorming in de Nederlandse somenleving, Amsterdam, Thesis publishers, 1994; en J.A. Koopal, Een onderzoek noar ervaringen van werknemers in de Amsterdamse bonenpool; Amsterdam, Ondernemingsraad Maatwerk Banenpool en Vakgroep Sociologie UVA, 1995.

35] J. Pen en J. Tinbergen, Noar een rechtvaardiger inkomensverdeling; Amsterdam, 1977; 'Hoeveel bedraagt de inkomensegalisatie sinds 1938?', ESB, 1976, jrg. 6I, blz. 880-884.

36] Voor een aanvulling op het eerder genoemde materiaal: J.P. de Kleijn en H. van de Stadt, 'Ontwikkelingen in de inkomensverdeling sinds 1970'; ESB, 1985, 1004-1009; voorts J. Pen, 'Economische ongelijkheid'; in: Sociale ongelijkheid; door J. Berting e.a., Siswo, Muiderberg, Coutinho, 1986.

${ }^{37]} \mathrm{Vgl}$. M.P van der Hoek, Inkomensverdeling en economische orde; Arnhem, Goude Quint, 1996.

38] Dit geldt ook voor de dwarsdoorsnedes van relatieve deprivatie door Van Praag en Hagenaars. Zie: Bernard M.S. van Praag e.a., Armoede in Nederland; een verkennend onderzoek naar aspecten van armoede en armoedebeleving in Nederland; Onderzoek in opdracht van het ministerie van Sociale Zaken en Werkgelegenheid, Den Haag, Vuga, 1993; A.J.M. Hagenaars. The perception of poverty, Alblasserdam, 1985. 
er studies die meer gericht zijn op de politiek-economische actualiteit en die meer in de diepte ingaan op de Nederlandse politieke en besluitvormingscultuur, op noodzaak van beleidsverandering en institutionele belemmeringen. Zo zijn er bijdragen waarin gewezen wordt op de noodzaak van aanpassingen van het sociaal-economisch bestel, 'opdat de sociale cohesie in ons land niet in gevaar komt' 39 . Er is sprake van afwentelingsmechanismen, bijvoorbeeld die van 'een onverantwoorde arbeidskostenontwikkeling via groeiende werkloosheid op een tamelijk royaal uitgevoerd socialezekerheidsstelsel' 40 . Als eenzijdigheden van de Nederlandse economie worden voorts genoemd de hoge collectieve uitgavenquôte en rigiditeiten op de arbeidsmarkt, die mede worden veroorzaakt door corporatistische arrangementen ${ }^{41}$. Zo zijn in deze visie de loonafspraken in CAO's, die vervolgens ook nog algemeen verbindend worden verklaard, verantwoordelijk voor de uitsluiting van mensen van de arbeidsmarkt ${ }^{42}$. Ook zijn er studies waarin wordt benadrukt dat er niet meer nieuwkomers tot de arbeidsmarkt kunnen worden toegelaten als tegelijkertijd de bescherming van degenen die reeds een baan hebben, op peil wordt gehouden; er moet dus worden gekozen ${ }^{43}$. De genoemde studies stellen het ontbreken van voorwaarden voor dynamiek aan de kaak en monden vaak uit in aanbevelingen voor meer liberalisering, deregulering en privatisering 44 .

Wat voor de een de oplossing is, is echter voor een ander het probleem: er zijn dus ook studies waarin wordt gewezen op de keerzijden van aantasting van bestaande rechten en op de risico's van liberalisering, deregulering en privatisering. Zo wordt het ontstaan gesignaleerd van een tegenstelling tussen bijvoorbeeld een rijke bovenlaag die niet aan nationale staten gebonden ('footloose') is en een relatief arme 'onderlaag' die dat wel is, met daartussenin een fluïde nieuwe klasse van mensen die nu eens wel dan weer niet deelnemen aan het arbeidsproces ${ }^{45}$. Ook wordt het gevaar benadrukt van dualisering van de arbeidsmarkt tussen mensen met flexibele arbeidsrelaties aan de ene kant en mensen met een vaste baan aan de andere kant 46 . Voorts worden de onverwachte gevaren van privatisering en deregulering onderzocht, zoals het onverzekerbaar raken van een deel van de bevolking, instabiliteit op de particuliere verzekeringsmarkt en processen van negatieve selectie ${ }^{47}$. En ten slotte wordt gewezen op de gevaren van een relatieve afname van de kwaliteit van het bestaan onder invloed van een verminderend 'egalitarisme' en een opkomende 'libertijnse' tijdgeest ${ }^{48}$.

Zoals gezegd gaat het niet om de vraag wie gelijk heeft, maar om de constatering dat er een verschil is tussen studies die de langetermijnontwikkelingen

39] L.A. Geelhoed, '1995: conjunctuurherstel of economisch herstel'; ESB, jrg. 80, 4-I-1995, blz. 4-7.

40] L.A. Geelhoed, 'Uitdagingen voor het sociaal-economisch bestel'; ESB, jrg. 79, 5-1-1994, blz. 5.

41] Bijv. OESO (1994), op. cit;; Eduard Bomhoff, Een Haagse lente?; Schoonhoven, Academic Press, 1994

${ }^{42}$ ] Zie voor een alternatieve visie B.M.S. van Praag en J.P. Hop; 'De matigende invloed van de Nederlandse vakbeweging'; ESB, jrg. 80. 8-11-1995; en reacties en discussie in ESB, jrg. 81, 10-I-1996, blz. 34 e.v.

43] Coen Teulings, 'Solidariteit en uitsluiting. De keerzijden van een en dezelfde medaille', in: Godfried Engbersen en René Gabriëls, Sferen van integratie. Naar een gedifferentieerd allochtonenbeleid; Amsterdam, Boom, 1995; A. van der Zwan, in themanummer 'Sociale ongelijkheid'; ESB, jrg. 72, 25-2-1987, blz. 118; en in: Mootschappelijke gelijkheid: de overheid een zorg; Utrecht/Antwerpen, Uitgeverij Veen, 1987.

44] C.G. Koedijk en J.J.M. Kremers, 'Regulering en groei in Nederland en Europa'; ESB, jrg. 81, 16-10-1996, blz. 848-852; en P.A.G. Bergeijk en R.G.G. Haffner, 'Op zoek naar dynamiek'; ESB, jrg. 78, 20-1-1993, blz. 52-56.

45] A. van der Zwan, Regressie en voortijdige rijpheid - ontbindingsverschijnselen van de verzorgingsstaot, Stichting Willem Dreeslezing, 1993; en van dezelfde auteur, 'Bestaat er voor het socialisme nog een herkansing?'; 5 en D, 1996, nr. 5., blz. 257-273.

46] Commissie Economische Deskundigen van de SER, Arbeidsmarkt, informatietechnologie en internationalisering, 's-Gravenhage, 1996.

47] A.J. Vermaat, 'Overzekerbaarheid: een groeiend probleem'; ESB, jrg. 80, 22-2-1995, blz. 169-182; en H.A.A. Verbon, 'De onverwachte effecten van maatregelen in de sociale zekerheid'; Stootscourant, 28 juni 1994, blz. 5.

48] J.W. de Beus, Economische gelijkheid en het goede leven; Amsterdam, Contact, 1993. 
benadrukken en studies die meer gericht zijn op de politiek-economische actualiteit en ingaan op economische wenselijkheden en op institutionele belemmeringen die de realisatie van die wenselijkheden in de weg staan.

Ook op andere fronten heeft de wetenschap zich de laatste jaren ten zeerste bekommerd om vraagstukken van ongelijkheid. Zo wijst de Overlegcommissie Verkenningen sociale cohesie aan als speerpunt van haar programma van 'maatschappelijk gestuurd sociaal-wetenschappelijk onderzoek'. In de toelichting bij dit onderwerp wijst zij erop dat sociale cohesie aan het einde van de negentiende eeuw bovenaan de maatschappelijke agenda kwam te staan en dat de retoriek over erodering van gezin, godsdienst en woongemeenschap door modernisering en rationalisatie tot op de dag van vandaag wordt gehoord. De commissie voegt daaraan toe dat 'nu de retoriek opmerkelijk constant is gebleven dit er niet toe mag leiden de socialecohesieproblematiek af te doen als een schijnprobleem. Eerder kan men eruit concluderen dat er telkens nieuwe bedreigingen voor dit aspect van het collectieve welzijn opduiken en dat de samenleving telkens nieuwe instituties moet genereren om daaraan het hoofd te bieden' ${ }^{49}$.

Ook heeft de zogeheten sociale problematiek een prominente plaats gekregen in het meerjarenprogramma voor de maatschappij- en gedragswetenschappen van de Nederlandse Organisatie voor Wetenschappelijk Onderzoek, NWO. Zo is in dat kader onlangs een uitgebreid onderzoekprogramma gestart naar de multiculturele samenleving met als oogmerken onder meer het verkrijgen van inzicht in 'de processen die maatschappelijke en culturele in- en uitsluiting bepalen en het in kaart brengen van de variatie in- en uitsluiting vanuit historisch en vergelijkend perspectief 50 .

Ten slotte heeft het ministerie van Sociale Zaken en Werkgelegenheid de thematiek van sociale uitsluiting en sociale cohesie als 'nieuw' thema in zijn programma van werkzaamheden opgenomen. In dat kader heeft dit ministerie aan het eind van 1996 zijn eerste jaarrapport over armoede en sociale uitsluiting' uitgebracht, met de bedoeling om in ieder geval voor de komende vier jaar elk jaar zo'n rapport uit te brengen ${ }^{51}$. Uit dit jaarrapport komt naar voren dat er weliswaar minder werkelijke armoede is dan gedacht, maar dat die armoede wel schrijnender is dan vermoed. Zo blijken 22.000 huishoudens soms te weinig te eten te hebben en kunnen 43.000 huishoudens door geldgebrek niet dagelijks een warme maaltijd nuttigen. Uit het jaarrapport komt voorts naar voren dat van de 657.000 tot 915.000 huishoudens die onder of op het sociaal minimum leven, het vooral werklozen, bijstandsontvangers en laag opgeleiden zijn die risico lopen op armoede ${ }^{52}$.

Ontegenzeglijk worden wetenschap en beleid op het terrein van tweedeling en ontwrichting nadrukkelijk in elkaars verlengde geplaatst. De subsidiestroom voor onderzoek op dit gebied is aanzienlijk. Dit heeft naast grote voordelen ook gevaren. Voor de (sociale en/of economische) wetenschap bestaat het gevaar dat het wetenschappelijk onderzoek soms wat al te gemakkelijk in het beleidsvertoog wordt opgenomen, waardoor de afstand tot de in dat vertoog gebezigde concepten niet altijd groot genoeg is. De erkenning dat ook de categorieën waarvan deze wetenschappen zich bedienen, een rol spelen in, c.q. de neerslag vormen van, een bepaalde politieke moraal blijft wel eens te zeer achterwege, zoals in het volgende hoofdstuk nader zal blijken. Andersom - en

49] Overlegcommissie Verkenningen, Een strategie voor de sociale wetenschoppen; Amsterdam, 1996, blz. 24.

50] NWO, Meerjarenplon 1997-200I; Kennis Verrijkt in uitvoering, Den Haag, 1996.

5'] Dit rapport is samengesteld door de Onderzoekschool Arbeid, Welzijn en Sociaal-Economisch Bestuur (AWSB) te Utrecht en het Sociaal en Cultureel Planbureau (SCP). Zie Engbersen, Vrooman en Snel (red.), op. cit.

52] Engbersen, Vrooman en Snel (red.), op. cit. 
ook dat zal in het volgende hoofdstuk duidelijk worden - kan het ondoordachte gebruik van als wetenschappelijk te boek staande data tot fouten leiden in de interpretatie en beoordeling van maatschappelijke processen. Bewustwording van de gevaren en beperkingen die met zulk onderzoek gepaard gaan, is dan ook van groot belang.

\section{I.4 Differentiatie en segmentatie: een conceptuele exercitie}

Van elke samenleving kunnen de leden worden onderscheiden op basis van een groot aantal kenmerken. Sommige van deze kenmerken zijn sociaal relevant, dat wil zeggen dat zij een belangrijke rol spelen bij het structureren en organiseren van de samenleving en ook in de perceptie van individuele personen. Sociaal relevante onderscheidingen zorgen empirisch gezien op macroniveau voor dynamiek en op microniveau voor motivatie; zij vormen daarmee de motor van het samenleven ${ }^{53}$.

In de meeste samenlevingen zijn er doorgaans tal van sociaal relevante onderscheidingscriteria. Doordat die onderscheidingscriteria op vele manieren door elkaar lopen, zorgen ze voor 'verband' in de desbetreffende samenleving. In sociaal-wetenschappelijk jargon heet het dan dat elke samenleving is gedifferentieerd, hetgeen niet anders wil zeggen dan dat heterogeniteit het cement vormt van een moderne samenleving. De 'klassieke' socioloog Emile Durkheim sprak in dit verband van organische solidariteit: een maatschappelijk verband dat door complementaire functies bijeen wordt gehouden. Sociale differentiatie en pluralisme vormen aldus de meest wezenlijke aspecten van een moderne samenleving.

\subsection{Sociaal relevante onderscheidingen}

Sociaal relevant zijn die onderscheidingen die bepalend zijn voor de inrichting, organisatie en geleding van een samenleving. In dit verband wordt al vlug gedacht aan zaken als arbeid, inkomen, huisvesting, opleiding, afkomst, godsdienst, geslacht, leeftijd enzovoort. Overigens vormen de sociaal relevante onderscheidingen een kleine minderheid uit het totaal van mogelijke onderscheidingen. Er zijn immers maar weinig samenlevingen ingericht op basis van criteria als lengte, gewicht of haarkleur.

De sociale relevantie van onderscheidingen is historisch specifiek: ze neemt in kracht toe of af. De rol van een voorname afkomst of een bepaalde religieuze denominatie is ooit uiterst sociaal relevant geweest. In de huidige Nederlandse samenleving is de organisatiekracht van die criteria sterk afgenomen. Andere, meer prestatieve, criteria zijn hiervoor in de plaats gekomen. Opleiding is er één van, maar ook beroep en inkomen zijn een steeds belangrijker rol gaan spelen als organisatiedimensies van de moderne samenleving. Omdat wij zijn gaan vinden dat dergelijke prestatiecriteria een belangrijker rol moeten spelen dan 'aangeboren' criteria, is in de afgelopen decennia veel verzet gerezen tegen ooit 'vanzelfsprekende' criteria van geslacht, ras, huidskleur en leeftijd ${ }^{54}$. Waar een samenleving nog te zeer langs dergelijke lijnen is georganiseerd, wordt gauw van 'discriminatie' gesproken.

53] Met maatschappelijke dynamiek wordt het brede gebied van gedragsreacties bedoeld tussen aan het ene uiteinde passiviteit en ledigheid, zoals het louter toekijken naar succes en falen van anderen (vgl. priverubrieken), en aan het andere uiteinde opstand en revolutie, zoals de revolution of rising expectations die soms als verklaring is aangevoerd voor het feit dat er in ontwikkelingslanden in de jaren zestig revoluties uitbraken, juist toen de welvaart in die landen toenam; vgl. Nripesh Podder, 'Relative deprivation, Envy and Economic Inequality'; Kyklos. Vol. 49, 1969, nr. 3, blz. 353-376.

54] Over bijv. ras als criterium, vgl. W.J de Bruijn, 'De verdrongen rasfactor' en R. Wentholt, 'Ras en wetenschap'; in: De linkse sociologie?; Utrecht, Bijleveld, 1968, resp. blz. 41-7l en 73-96. Beide auteurs laten zien hoe ras in Nederland enige tijd een vanzelfsprekend onderdeel heeft uitgemaakt van het intellectuele en wetenschappelijke discours van voor de Tweede Wereldoorlog. 
De sociale relevantie van onderscheidingen is bovendien cultuur-specifiek: dezelfde onderscheidingscriteria spelen in verschillende culturen een verschillende rol (vgl. afkomst, godsdienst, gender), terwijl uiteenlopende onderscheidingscriteria in verschillende samenlevingen juist eenzelfde rol vervullen (vgl. leeftijd en opleiding als graadmeter van deskundigheid of de discussie over de culturele specificiteit van universele mensenrechten).

\subsubsection{Patronen van sociale differentiatie}

Sociale differentiatie geschiedt doorgaans langs twee lijnen; er is differentiatie langs verticale lijnen en er is differentiatie langs horizontale lijnen. De eerste is geënt op opvattingen (bijv. m.b.t. geloof, etniciteit, huidskleur), de tweede is geënt op materiële levenskansen (bijv. arbeid vs. kapitaal, adel vs. 'commons'). In extreme vorm leidt de eerste tot een plurale of verzuilde samenleving, de tweede tot een standen-en/of klassensamenleving. In de sociale differentiatie van moderne samenlevingen zijn doorgaans beide lijnen van belang en is er niet één enkele factor waaraan de organisatie van de samenleving is opgehangen; men spreekt dan van een pluralistische samenleving. De discussie over de vraag of een moderne samenleving tendeert in de richting van een klassensamenleving of in de richting van verzuiling gaat, is dus altijd relatief. Ten opzichte van een imaginair evenwicht worden dan ontwikkelingen waargenomen die in de ene of de andere richting gaan.

\subsubsection{Sociale segmentatie}

Er is sprake van een proces van sociale segmentatie indien aan twee voorwaarden wordt voldaan. De sociaal relevante onderscheidingen van een samenleving gaan zich exclusiever op één der beide lijnen bevinden, waardoor kruisverbanden tussen bevolkingsgroepen schaarser worden. Tegelijkertijd worden de grenzen tussen de onderscheiden groepen moeilijker doordringbaar. Gevolg van het eerste is dat de sociaal relevante onderscheidingscriteria zich bijvoorbeeld alle rondom de godsdienst gaan concentreren. Alle andere onderscheidingscriteria worden hieraan ondergeschikt en verliezen derhalve aan zelfstandige onderscheidings- en organisatiekracht. Op die manier kan een 'zuil' tot stand komen, die als het ware een geheel eigen microkosmos vormt: een eigen politieke partij, eigen scholen, een eigen voetbalcompetitie, enzovoort. Uiteindelijk raakt een samenleving georganiseerd op basis van dat ene criterium. Bovendien is er heel wat voor nodig, wil een individu zich uit zijn zuil begeven en aan onderdelen van een andere microkosmos deel hebben: 'gemengde huwelijken' zijn uit den boze, voetballers die toch op zondag willen spelen, worden met de nek aangekeken. Overigens is een 'zuivere' vorm van sociale segmentatie een contradictio in terminis, omdat de desbetreffende samenleving dan ophoudt te bestaan. Bosnië bood hiervan gedurende de afgelopen jaren een schrijnend voorbeeld; een scherpe vorm van segmentatie op basis van de taal, zoals in België en Zwitserland het geval is, lijkt wel nog steeds voldoende verbindingsmogelijkheden te bieden voor het bestaan van één samenleving.

\subsubsection{Segmentatie en cohesie}

Sociale segmentatie is over het algemeen aanleiding tot cohesie, solidariteit en organisatie-opbouw binnen het segment en tot concurrentie, conflict en emancipatiestrijd tussen de segmenten. Overigens kan het conflict tussen de segmenten op tal van manieren zijn geïnstitutionaliseerd, georganiseerd of gepacificeerd. Het conflict wordt dan vaak niet meer als zodanig herkend en wordt als normale manier van samenleven beschouwd. In het geval van een verzuilde samenleving bijvoorbeeld via 'pacificatie aan de top', in het geval van een klassensamenleving door het geïnstitutionaliseerd overleg der 'sociale partners' en in het geval van de gendersamenleving door de vanzelfsprekend- 
heid van kostwinnersvergoedingen, ongelijke betaling en alleenverdienersregelingen. De aanwezigheid van dergelijke vormen van geïnstitutionaliseerd conflict is een teken dat van een zuivere vorm van sociale segmentatie nog geen sprake of geen sprake meer is.

Hoe zuiverder de vorm van sociale segmentatie, des te splijtender of ontbindender is haar werking in een samenleving; zij maakt uiteindelijk en per definitie een einde aan het samenleven. Tussen de segmenten bestaan er dan steeds minder vormen van institutionalisering van conflict, van overkoepelende wetgeving, enzovoort. In zo'n situatie is er meer dat verdeelt dan verenigt. Dat samenlevingen aan segmentatie te gronde gaan, komt overigens zelden voor. Schuyt had dan ook gelijk toen hij onlangs schreef:

Een samenleving valt niet zo snel uit elkaar. Ze is geen gammele oude stoel, geen ding, geen lichaam dat in ontbinding kan raken. De sociale orde gaat door, normen en waarden vervallen niet, want voor het oude komt iets anders in de plaats. Een absoluut sociaal nulpunt komt zelden in zicht. Ook in tijden van cholera blijft liefde opbloeien. ${ }^{55}$

\section{I.5 Tweedeling in perspectief}

In het licht van het bovenstaande is de huidige discussie over tweedeling, 'underclass' en andere vormen van segmentatie een discussie over tendenties, niet over absolute grootheden. Men kan het zich als volgt voorstellen: waar tegenwoordig over segmentatie of tweedeling wordt gesproken, gaat het om een doorbreking van een situatie of ontwikkeling die, al of niet terecht, als betrekkelijk evenwichtig wordt ervaren. De krachten die tot een dergelijke doorbreking leiden, kunnen zowel endogeen als exogeen zijn. Hierbij wordt steeds de veronderstelling gehanteerd dat de bewuste doorbraak, indien niet op enigerlei wijze tegengehouden door expliciet beleid, verstoring van de bestaande maatschappelijke verhoudingen tot gevolg zal hebben. De betrekkelijk evenwichtig ervaren toestand en ontwikkeling wordt in het publiek debat veelal gerepresenteerd door de verzorgingsstaat en de 'vervolmaking' van het stelsel van sociale zekerheid tussen 1950 en 1975. In hetzelfde debat worden individualisering en calculerend gedrag van burgers veelal beschouwd als bedreigende endogene ontwikkelingen en globalisering en technologische veranderingen als bedreigende exogene factoren.

Het kan geen kwaad er nogmaals op te wijzen, dat tweedeling niet automatisch inhoudt dat een samenleving uit elkaar valt. Al eerder is vastgesteld dat grote ongelijkheden en geringe toegankelijkheid en openheid niet hebben kunnen verhinderen dat samenlevingen gedurende lange tijd als uitermate coherent en cohesief door het leven zijn gegaan. Blijkbaar is de mate waarin in een bepaald tijdvak ongelijkheden als 'normaal' of 'abnormaal' worden ervaren, een even zo grote factor in de perceptie van maatschappelijke ontwrichting of tweedeling als de feitelijke ongelijkheden zelf. Zo impliceert de verwachting van een 'gunstiger' toekomst niet dat ook het heden er aantrekkelijk uitziet. Integendeel, uit de analyse zal blijken dat juist de periode van de jaren tachtig kan gelden als een sociaal en cultureel dieptepunt. Voor velen is bijvoorbeeld de sociale zekerheid van vangnet tot fuik geworden en is nietdeelname aan arbeid ook gaan betekenen dat zij kansen tot ontplooiing mislopen. Deze feitelijkheid beïnvloedt de definitie van de situatie van dit moment, waarvan visies op dreigende tweedeling en ontwrichting in de toekomst uitgaan.

55] Kees Schuyt, 'De samenleving is geen oude stoel'; column Volkskront, juni 1996. 
Voor de onderhavige studie betekent dit dat niet alleen gelet moet worden op ontwikkelingen op feitelijk niveau, maar ook op veranderingen in de sfeer van benaderingen van de sociale werkelijkheid, van opvattingen en van ideologieën. Daarom onderzoekt de Raad niet slechts ontwikkelingen op een aantal sociaal relevante onderscheidingscriteria, maar kijkt hij ook naar ontwikkelingen in de sociale relevantie zelf van die onderscheidingscriteria. Het eerste wordt door empirisch en longitudinaal materiaal ondersteund, voor het tweede is aanmerkelijk minder empirisch materiaal beschikbaar en is er overeenkomstig meer ruimte voor interpretatie.

In de discussie over tweedeling en maatschappelijke ontwrichting grijpen heden en toekomst zodanig in elkaar dat het niet altijd eenvoudig is feiten en opvattingen uit elkaar te houden of op de juiste wijze in elkaars verlengde te plaatsen. Anders gezegd: feitelijke ontwikkelingen zouden zeer wel in de 'goede' richting kunnen gaan, maar doordat de acceleratie van maatschappelijke wensen sneller verloopt, kan de kloof tussen wens en werkelijkheid, en daarmee ook de zorg over het achterblijven van een gewenste ontwikkeling, toch toenemen. Dit verklaart waarom de zorg over een ontwikkeling vaak toeneemt als die ontwikkeling juist een positieve richting begint in te slaan. Naarmate de normaliteit of de vanzelfsprekendheid van de bestaande ongelijkheden beginnen te verrafelen (meestal door veranderde externe omstandigheden), en er dus feitelijk 'verbetering' begint op te treden, worden de nog bestaande ongelijkheden als disruptief herkend. Dit leidt tot de paradoxale vaststelling dat de discussie over en de vrees voor maatschappelijke ontwrichting kan ontstaan op het moment dat de feitelijke ontwikkelingen de 'goede' kant beginnen op te gaan. Zo kan de constatering van armoede en uitsluiting zich tegelijk voordoen met de constatering van sociale veranderingen ten goede. De ene constatering wordt niet onwaar omdat de andere waar blijkt te zijn ${ }^{56}$. Zoals gezegd zijn aan het einde van de jaren tachtig en begin van de jaren negentig grote groepen buiten het arbeidsproces komen te staan, terwijl het economisch juist beter begon te gaan. Dit kan niet alleen leiden tot meer vragen bij de vanzelfsprekendheid van die bestaande toestand, maar ook tot meer 'ongeduld' over de voortduring ervan.

Om in dit ingewikkelde complex van feiten en opvattingen, heden en toekomst een weg te banen, is dit rapport als volgt opgebouwd. In hoofdstuk 2 wordt eerst ingegaan op de empirische en met name longitudinale gegevens omtrent de feitelijke ontwikkelingen op een drietal belangrijke maatschappelijke verdelingsdimensies. De drie dimensies - beroep, onderwijs en inkomen - zijn gekozen, omdat zij het kader vormen waarbinnen de sociaal-culturele ontwikkeling 'ruimte' krijgt. Naar de mate dat dit kader zich in positieve zin ontwikkelt, wordt de kans op een harmonieuze sociaal-culturele ontwikkeling navenant groter. Dit wil nog niet zeggen dat die positieve ontwikkeling zich ook feitelijk zal voordoen, maar in ieder geval is er dan de ruimte waarbinnen deze kan plaatsvinden. Ontwikkelt het kader zich evenwel in negatieve richting, dan is de kans groot dat sociaal-culturele verschillen hoger worden opgespeeld. De te benutten ruimte wordt kleiner en de kans dat groepen elkaar over en weer van de slechte uitkomsten dan wel slechte vooruitzichten de schuld geven, eveneens navenant groter. De bevindingen van hoofdstuk 2 omtrent de ontwikkelingen op voornoemde drie verdelingsdimensies zeggen nog weinig over de kans dat de onderkant van die drie afzonderlijke verdelingen in onevenredige mate wordt bezet door bepaalde herkenbare groepen. Vandaar dat in hoofdstuk 3 de schijnwerper wordt gericht op de toekomstige positie van 'marginale' groepen, om na te gaan of die groepen als zodanig meer dan thans de kans lopen van maatschappelijke participatie te worden uitge-

56] Zie het verschil in toon tussen de 'aanklacht' van bisschop Muskens van Breda over de verwaarlozing van het armoedevraagstuk door de politiek (VPRO-televisie, 2 oktober 1996) en de Troonrede uitgesproken op 17 september 1996. 
sloten. Ten slotte worden in hoofdstuk 4 de lijnen en resultaten van de analyses bijeengebracht in een beeld over de toekomstige sociaal-culturele ontwikkeling, met name van de kansen en bedreigingen voor de sociale cohesie. 


\section{Veranderingen op drie verdelingsdimensies}

\section{I Inleiding}

Doel van dit hoofdstuk is in kaart te brengen hoe de verdeling van sociaal relevante goederen zich in de afgelopen decennia heeft ontwikkeld en hoe deze verdeling zich verder kan ontwikkelen tot 2015 . Het gaat hierbij om de drie in hoofdstuk 1 genoemde verdelingsdimensies, beroep, onderwijs en inkomen, die het kader vormen waarbinnen maatschappelijke samenhang tot stand komt. In dit hoofdstuk wordt, op basis van de best beschikbare kennis en rekening houdend met nu reeds voorzienbare trends en ontwikkelingen, de toekomst van deze dimensies bezien volgens eenzelfde patroon. Per onderscheiden dimensie komen steeds vier vragen aan de orde:

1. valt er voor de middellange termijn (tot 2015) iets te zeggen over de aard en betekenis, de 'sociale relevantie' van het maatschappelijk goed, alsmede over veranderingen hierin;

2. welke ontwikkelingen spelen zich af op het punt van de toegankelijkheid van het te verdelen goed;

3. in hoeverre is sprake van 'scheefheid' van de betrokken verdeling;

4. zijn er ook ontwikkelingen waarneembaar op het punt van de openheid van of mobiliteit op de desbetreffende verdelingsdimensie?

In het wetenschappelijk onderzoek naar de verdeling van sociaal relevante goederen treden vooral de twee laatste aspecten op de voorgrond. Voor de mogelijke verschuivingen in de aard en betekenis van het te verdelen goed, alsmede voor de vraag naar de toegankelijkheid van de verdelingsdimensie, bestaat doorgaans minder aandacht. Toch zijn ook die van groot belang voor een sociaal-culturele toekomstverkenning. Met name moet de mogelijkheid onder ogen worden gezien dat het te verdelen goed (beroep, onderwijs, inkomen) niet alleen anders wordt en zal worden verdeeld, maar ook zelf wezenlijk van karakter en maatschappelijke betekenis kan veranderen. De sociale relevantie van een onderscheidingscriterium kan toe- of afnemen ten opzichte van andere onderscheidingscriteria.

Dit is het gemakkelijkst uit te leggen aan de hand van de dimensie 'beroep'. Allereerst is met de ontwikkeling van de economie omtrent een steeds groter deel van functies die op de arbeidsmarkt worden vervuld, moeilijk te zeggen om welk 'beroep' het nu eigenlijk gaat. De traditionele ambachtslieden (rijwielhersteller, melkbezorger) hebben plaats gemaakt voor veel gedifferentieerder bedrijfjes en bedrijven, het aantal beroepen is sterk toegenomen, niet in het minst door de opkomst van vele soorten beleidsmedewerkers bij de overheid en in de bedrijvenwereld. Hiernaast kan ook het belang van het hebben van een beroep of functie in de loop van de tijd groter of kleiner zijn geworden. De aanwezigheid van een stelsel van sociale zekerheid kan in dit opzicht verschil maken, evenals een ontwikkeling van individualisering, waardoor een groter deel van de bevolking naar economische onafhankelijkheid streeft en dus een plaats op deze verdelingsdimensie ambieert. Dit alles moet in een historische èn toekomstgerichte vergelijking worden meegenomen.

Iets dergelijks geldt ook voor de toegankelijkheid van de verdelingsdimensies. De toestroom van vrouwen naar de arbeidsmarkt heeft er bijvoorbeeld voor gezorgd dat een categorie mensen die tot dan toe (vanwege welke oorzaak dan ook) feitelijk geen toegang had tot de verdelingsdimensies beroep en inkomen, dit 'ineens' wel kreeg. Dit heeft uiteraard consequenties gehad voor de wijze 
waarop het betreffende sociaal relevante goed wordt verdeeld. Met betrekking tot inkomen valt bijvoorbeeld vast te stellen dat het aantal inkomensverdieners in een tijdsbestek van enkele decennia is gestegen van 40 tot 65 procent van de potentiële beroepsbevolking. Dat die nieuwe instroom zich aanvankelijk vooral aan de onderkant van de verdeling ophoudt, ligt voor de hand. Te concluderen dat de verdeling hiermee schever of onevenwichtiger is geworden, is op zichzelf correct. Niet correct is het echter om hieraan automatisch een negatief moreel oordeel over de ontwikkeling van de verdeling te verbinden. Men ziet dan immers over het hoofd dat de betrokkenen - nieuw toetredende vrouwen - in de voorafgaande periode in het geheel geen inkomen hadden. De statistische presentatie gaat op deze manier voorbij aan een markante ontwikkeling en suggereert er een die niet heeft plaatsgevonden of die in elk geval niet kan blijken uit deze macrocijfers. Het ware derhalve beter om naast de gebruikelijke presentatie ook een statistische presentatie te bieden waarin 'nul-inkomens' en 'nul-beroepen' worden meegeteld. In het vervolg van dit hoofdstuk zal een dergelijk onderscheid worden gemaakt tussen de traditionele 'exclusieve' presentatie van de betreffende verdelingsdimensie en een meer 'inclusieve' presentatie, een onderscheid dat van groot belang zal blijken voor de beoordeling van de relevante maatschappelijke processen ${ }^{1}$.

Voor de 'best beschikbare kennis' over de relevante verdelingsdimensies heeft de Raad kennis genomen van een groot aantal studies die in de afgelopen jaren zijn verschenen. Hierbij moeten met name studies van het Centraal Planbureau (CPB) ${ }^{2}$ en het Sociaal en Cultureel Planbureau (SCP) ${ }^{3}$ worden gememoreerd. Voor dit rapport is voorts in belangrijke mate gebruik gemaakt van een studie naar sociale segmentatie, die in opdracht van de Raad door een groep onderzoekers van de universiteiten van Utrecht en Nijmegen is verricht ${ }^{4}$.

\subsection{Beroep}

Het beroep dat iemand uitoefent, is vanouds in hoge mate bepalend voor de plaats op de sociale ladder. De aard en het niveau van iemands beroep hangen op verschillende manieren samen met het genoten onderwijs en zijn zelf weer van invloed op het te verwerven inkomen. Hier gaat het echter niet in eerste instantie om de causale keten, waarin beroep en functie als schaars maatschappelijk kapitaal zijn opgenomen, maar om de ontwikkelingen op de verdelingsdimensie zelf. Aard, niveau, aantal en richting van beroepen, alsmede de verschuivingen daarbinnen, vormen dan het eerste aandachtspunt. Dit brengt ons vervolgens vanzelf op de verwevenheid met andere dimensies van maatschappelijke verdeling.

\subsubsection{Aard en betekenis}

De eerste vraag die moet worden gesteld, betreft de verschuivingen in de aard en betekenis van het beroep die relevant zijn voor de verdeling van dit schaarse kapitaalgoed. Hier hebben in de afgelopen decennia welhaast revolutionaire veranderingen plaatsgevonden. Zo heeft de economische ontwikkeling een grote verschuiving teweeggebracht in de verdeling van het werkgelegenheidsaandeel over de verschillende sectoren. Het aandeel van de primaire

'] Vgl. Hans P.M. Adriaansens, 'De calculus van de vergeten poedel'; in: Beleidswetenschap en praktijk l; door G. Alberts (red.), Nijmegen, 1996, blz. 105-114.

2] Centraal Planbureau, Nederiand in Drievoud. Een scenariostudie van de Nederlandse economie, 1990-2015; 's-Gravenhage, Sdu Uitgeverij, 1992.

3] Sociaal en Cultureel Planbureau, Sociaal en Cultureel Rapport 1994; Rijswijk, 1994.

4] De sociale segmentatie van Nederland in 2015; door H.B.G. Ganzeboom en W.C. Ultee (red.), WRR, Voorstudie en achtergronden nr. 96, 's-Gravenhage, Sdu Uitgevers, 1997. 
of landbouwsector kromp van ongeveer 20 procent in 1930 tot slechts 4 procent nu. Omvatte de secundaire of industriesector in 1960 nog één derde van de werkgelegenheid, inmiddels is deze gekrompen tot niet meer dan één vijfde. Hiertegenover staat de enorme werkgelegenheidsgroei van zowel de tertiaire (zakelijke) als de quartaire (niet-commerciële) dienstverlening. Het werkgelegenheidsaandeel van deze sectoren samen groeide van minder dan de helft in 1960 tot driekwart nu.

Het gaat hier om een verschuiving met belangrijke gevolgen voor de kwaliteit van de beroepsarbeid. Dit kan ook worden geïllustreerd aan de hand van het aandeel van informatiearbeid in de werkgelegenheid. Onlangs zijn voor Nederland de gegevens over de historische beroepensamenstelling van de bevolking bewerkt en ingedeeld volgens de bedrijfsindeling van $1920{ }^{5}$. Een indeling naar klassen van bedrijvigheid sluit weliswaar niet aan bij een indeling van de beroepsbevolking in informatiearbeiders en handarbeiders, maar door het aandeel van de beroepsbevolking in op informatie gerichte bedrijfsklassen te volgen, kan een aardige indruk worden verkregen van de omvang van de verschuiving. Bedrijfsklassen waarin informatie bij uitstek een rol speelt, zijn het krediet- en bankwezen, het verzekeringswezen, het algemeen bestuur, de vrije beroepen en het onderwijs. Het aandeel van de beroepsbevolking in deze bedrijfsklassen is, zoals tabel 2.1 laat zien, in de afgelopen 150 jaar sterk toegenomen.

Tabel 2.1 Aandeel van de beroepsbevolking in op informatie gerichte

bedrijfsklassen (percentages)

\begin{tabular}{lllllllll}
\hline 1849 & 1859 & 1889 & 1899 & 1909 & 1920 & 1930 & 1960 & 1990 \\
2,8 & 2,7 & 4,2 & 4,3 & 5,0 & 7,4 & 7,4 & 11,8 & 23,8 \\
\hline
\end{tabular}

Bron: $\quad$ WRR op basis van C.A. Oomens en G.P. den Bakker, De beroepsbevolking in Nederland 1849-1990; Centraal Bureau voor de Statistiek, Supplement bij de Sociaal-economische Maandstatistiek, jaargang 1994-2.

Wetenschap en techniek hebben hun greep op de economische productie voortdurend verstevigd en het aanzien van de beroepsarbeid sterk gewijzigd. (Te) algemeen getypeerd gaat het om een verschuiving van arbeid gebaseerd op spierkracht naar arbeid gebaseerd op denkvermogen: de 'dematerialisering' of 'kennisintensivering' van de productie ${ }^{6}$. Een dergelijke ontwikkeling heeft de laatste jaren een extra impuls gekregen door de voortschrijdende informatisering of digitalisering van productieprocessen. Bekendheid met geautomatiseerde informatieverwerking is intussen voor een toenemend aantal beroepen of functies een must geworden. Door diezelfde ontwikkeling is ook de mate waarin beroepen van elkaar kunnen worden afgebakend, sterk afgenomen.

De betekenis van een dergelijke verschuiving moet niet worden onderschat: in kwalitatief opzicht is er zelfs aanleiding te spreken van 'emancipatie van de arbeid' 7. Voor een toenemend aantal mensen heeft arbeid zich gedurende de afgelopen eeuw ontwikkeld van iets dat nadrukkelijk buiten het individuele welzijn stond en waartegen mensen moesten worden beschermd (het extrinsieke of vervreemdende arbeidsconcept uit het 'industriële' tijdperk), tot iets dat steeds meer deel van de individuele welzijnservaring is geworden en waartegen bescherming geleidelijk overbodig en contraproductief begint te

5] C.A. Oomens en G.P. den Bakker, De beroepsbevolking in Nederlond 1849-1990; Centraal Bureau voor de Statistiek, Supplement bij de Sociaal-economische Maandstatistiek, 1994, nr. 2.

6] WRR, Een werkend perspectief; Arbeidsparticipatie in de jaren '90; Rapporten aan de Regering nr. 38, 's-Gravenhage, Sdu Uitgeverij, 1990, blz. 36.

] Vgl. hfdst. 4 van dit rapport. 
worden (het intrinsieke arbeidsconcept van de 'diensten'economie). Wanneer nu steeds meer beroepsbeoefenaren worden aangesproken op kennis, creativiteit, eigen verantwoordelijkheid en zorgzaamheid, dan tekent zich een ontwikkeling af die het traditionele concept van arbeid als 'labeur' naar de achtergrond dringt. De voorzichtigheid gebiedt te zeggen dat deze ontwikkeling zeer geleidelijk verloopt en dat er nog tal van taken en functies zijn die aan hun vervullers weinig bevrediging schenken. Dat zijn dan zeker niet alleen de meer traditionele functies; ook functies die wel degelijk door de moderne informatietechnologie zijn aangeraakt, kunnen vervelend en vervreemdend zijn. In dit verband is erop gewezen dat de automatisering in menige industriële sector de autonomie van de operator eerder heeft verminderd dan verruimd ${ }^{8}$. Maar voor het leeuwendeel van de moderne kennisintensieve en zorgintensieve beroepsarbeid geldt dat het geleidelijk meer in de buurt van een zinvolle levensvervulling is komen te liggen. Hierdoor wordt ook de hang naar het verwerven van een plaats op deze verdelingsdimensie groter. Dit stelt vervolgens weer hoge eisen aan de omvang van de werkgelegenheid.

Het toekomstige belang van de beroepsarbeid is een van de meest omstreden aangelegenheden in het debat over de maatschappelijke ontwikkeling en eventuele tweedelingsperspectieven. In de laatste decennia vallen hierbij twee opvattingen op te merken. In de jaren zeventig is een opvatting gegroeid die niet alleen een geleidelijk einde aan de beroepsarbeid voorzag, maar dit bovendien niet erg vond. Dat deze opvatting kon groeien, had te maken met het proces van de-industrialisatie, de economische (olie)crisis en het relatieve succes van de door de verzorgingsstaat geboden inkomensgaranties. De samenleving zou zo minder afhankelijk worden van de traditioneel als negatief ervaren kanten van de economische productie, zij zou een ontspannen karakter krijgen en het belangrijkste probleem was te voorzien in adequate vormen van vrijetijdsactiviteit. Hoezeer deze opvatting tot de praktijk van de laatste decennia is doorgedrongen, kan worden afgelezen aan de relatieve berusting waarmee lange tijd op de groeiende werkloosheid is gereageerd, alsmede wellicht ook aan de coulance die in de uitvoering van de sociale zekerheid is opgetreden.

De andere opvatting begint vooral in de jaren negentig een rol van betekenis te spelen. Hierin geldt arbeid als de hoofdroute naar maatschappelijke participatie. In deze opvatting wordt erop gewezen dat de maatschappelijke participatie die niet in het verlengde ligt van arbeidsdeelname, steeds moeilijker van de grond komt. Sociale uitsluiting vindt haar wortels in het niet verwerven van toegang van de arbeidsmarkt. Voor een adequaat sociaal beleid zijn ondernemingszin en economische groei elementaire voorwaarden. De praktijk van dit denken uit zich momenteel in een herijking van de sociale zekerheid, in de herdefiniëring van rechten en plichten, in de stimulering van de vraagzijde van de arbeidsmarkt en niet in de laatste plaats in het credo van het 'paarse' kabinet: 'werk, werk, werk!'

De mate waarin de arbeidsparticipatie-opvatting zal doorzetten, zal naar verwachting vooral afhangen van de mate waarin voor ieder die dit wil, een perspectief kan worden geopend op werk in de vorm van betaalde activiteit. Dit vergt, afgezien van een gunstige economische ontwikkeling, een vasthoudend beleid van omzetting van de traditionele vormen van sociale zekerheid naar vormen van sociale zekerheid die individuele verantwoordelijkheid, activiteit en ondernemingszin willen activeren. Dit zal ongetwijfeld met problemen gepaard blijven gaan, waardoor ook de 'vrijetijdsopvatting' van arbeid èn de daarbij horende praktijken de komende decennia nog regelmatig van zich zul-

8] Bram Steijn en Marco de Witte, 'Chaotische patronen in de regradatie van de arbeid'; Tijdschrift voor Arbeidsvraagstukken, 1996 , jrg. 12, nr. 2, blz. 108-123. 
len doen horen. Niettemin wordt er hieronder van uitgegaan dat de hernieuwde aandacht voor werk en voor arbeidsdeelname voor de middellange termijn bij uitstek de vertaling zal (blijven) vormen van de behoefte aan individuele verantwoordelijkheid en zelfstandigheid.

\subsubsection{Toegankelijkheid}

Een tweede 'revolutie' die in de naoorlogse periode op de verdelingsdimensie 'beroep' heeft plaatsgevonden, betreft het arbeidsaanbod. De voortschrijdende individualisering heeft zich mede vertaald in een sterke toename van het aantal huishoudens. Sinds 1960 is dit aantal verdubbeld, van 3,2 miljoen naar 6,4 miljoen. Het aantal eenpersoonshuishoudens nam nog veel sterker toe, van 0,4 miljoen naar 2 miljoen mensen ${ }^{9}$. De toename van het aantal huishoudens heeft geleid tot een groter beroep op de arbeidsmarkt, omdat velen via beroepsarbeid economische zelfstandigheid trachten te verwerven. Maar ook binnen de meerpersoonshuishoudens zijn belangrijke veranderingen in het arbeidsaanbod opgetreden. Van de huishoudens waarin twee volwassenen een (echt)paar vormen, doet een nog steeds groeiend aantal een dubbel beroep op de arbeidsmarkt. Dat is gepaard gegaan met zowel een forse stijging van het aantal werkzame personen als met een toename van het verschijnsel deeltijdarbeid. Sinds 1960 is het aantal werkzame personen met meer dan 50 procent toegenomen ${ }^{10}$, terwijl de werkgelegenheid in die periode - in arbeidsjaren gemeten - met slechts 29 procent is gegroeid en in arbeidsuren met slechts 5 procent.

Het kan dus niet anders of het aantal deeltijdwerkers moet fors zijn gestegen. Dat blijkt ook uit de cijfers: tussen 1979 en 1995 steeg het aantal in deeltijd werkende personen van 17 naar 37 procent ${ }^{11}$. Met deze omvangrijke arbeid in deeltijd is Nederland in Europa een uitzondering. Of het ook koploper is, in de zin dat deze trend ook in andere landen zal optreden, is niet zeker maar wel waarschijnlijk. Opmerkelijk is in ieder geval dat bijvoorbeeld in de Bondsrepubliek een soortgelijke ontwikkeling van regeringswege wordt gestimuleerd. Ook bij de vakbeweging begint voor dit perspectief begrip te ontstaan. Even belangrijk is het feit dat in Nederland bij de werkenden zelf een groeiende adhesie voor deeltijdarbeid valt waar te nemen, dat ook de ontwikkeling van de economische productie een groeiende behoefte aan flexibele contracten te zien geeft en dat bovendien de voortdurende schaarste aan werkgelegenheid het verdelings- en arbeidstijdverkortingsmotief nog wel enige tijd overeind zal houden.

Tabel 2.2 laat zien hoe de arbeidsparticipatie zich ontwikkeld heeft voor de verschillende huishoudens. Opvallend is de sterke toename van het aantal tweeverdieners, zowel bij de huishoudens met en zonder kinderen. Ook bij de eenpersoonshuishoudens is sprake van een stijgende arbeidsparticipatie, al is die toename geringer. Daarbij moet wel rekening gehouden worden met het gegeven dat veel alleenstaanden ouder dan 65 zijn en daarom niet meer actief op de arbeidsmarkt.

9] Zie Centraal Bureau voor de Statistiek, Vijfennegentig jaar stotistiek in tijdreekser; 's-Gravenhage, Sdu Uitgeverij, 1994.

10] Sociaal en Cultureel Planbureau, Sociaal en Cultureel Rapport 1994; Rijswijk, 1994, blz. 111.

i1] Zie OESO, Employment Outlook; juli 1996, Parijs, tabel E. 
1981

1993

\begin{tabular}{lrrrrrrrr} 
personen werkzaam & & $\mathbf{0}$ & $\mathbf{I}$ & $\mathbf{2}$ & & $\mathbf{0}$ & $\mathbf{2}$ & $\mathbf{2}$ \\
\hline Particuliere huishoudens waarvan: & 5035 & & & & 6368 & & \\
eenpersoons & 1101 & 65,8 & 34,2 & & 1968 & 62,3 & 37,7 & \\
meerpersoons met twee of meer volwassenen & 1899 & 34,9 & 31,4 & 33,7 & 2604 & 34,6 & 24,9 & 40,4 \\
eenoudergezin & 144 & 56,3 & 43,7 & & 179 & 57,8 & 42,2 & \\
paar met kinderen & 1891 & 5,6 & 67,4 & 27,0 & 1617 & 6,5 & 53,8 & 39,8 \\
\hline
\end{tabular}

Bron: M.P. Eijkhout, 'Huishoudens en hun arbeidsparticipatie 1981-1993'; Centraal Bureau voor de Statistiek, Sociaal-Economische Maandstatistiek; 1995/2.

Hoewel de formele inactiviteit (het percentage van de potentiële beroepsbevolking zonder betaald werk) inmiddels terugloopt en een niveau heeft bereikt waarbij in de jaren zestig nog van volledige werkgelegenheid kon worden gesproken, is het werkloosheidsprobleem daarmee nog niet opgelost. Naar nader zal blijken in hoofdstuk 3 , blijven specifieke bevolkingsgroepen voor langere perioden van betaald werk verstoken; er is zelfs een 'cultuur van werkloosheid' 12 gegroeid. Naar de mate dat mensen langer in een situatie van onvrijwillige werkloosheid verkeren, worden de barrières voor toegang tot de arbeidsmarkt voor hen hoger. Desbetreffend onderzoek, gebaseerd op gegevens van de periode 1980-1992, bevestigt het bestaan van een fors aantal blijvers in de bijstand', zij het dat dit aantal wel is teruggelopen van meer dan een derde naar ongeveer een kwart van de instroom na vijf jaar (zie tabel 2.3). Ook voor de RWW is de tendens dalende; bovendien liggen de cijfers daar lager. Helaas zijn op dezelfde basis geen recentere cijfers gepubliceerd. Wel zijn min of meer vergelijkbare cijfers opgenomen in Engbersen e.a. 13. Daaruit komt naar voren dat voor 1994 en 1995 de duur weer is opgelopen. Onduidelijk is wat de invloed van de conjuncturele teruggang in de jaren 1992-1994 is geweest.

Naast deze ontwikkeling van de formele beroepsarbeid is er ook een beduidend aantal arbeidsjaren in het informele circuit. Aan te nemen valt dat de omvang van het 'leger' formeel inactieven stimulerend heeft gewerkt op de opkomst en bestendiging van een circuit van informele activiteit. Vrijwilligerswerk was vanouds al een vorm van informele activiteit die een grote rol heeft gespeeld in de periode dat formele inactiviteit van vrouwen sociaal en cultureel geaccepteerd was. Met de groei van de werkloosheid is dit circuit ook voor mannen toenemend interessant geworden. Hierbij moet echter ook worden aangetekend dat veel van het vrijwilligerswerk wordt gedaan door mensen met een baan, iets wat ook geldt voor die andere vorm van informele activiteit: het zwarte en grijze werk. Al met al komen schattingen over verrichte arbeid door particulieren voor particulieren en bedrijven neer op 300 à 400 duizend mensjaren in het informele circuit en 200 à 300 duizend in het zwarte circuit ${ }^{14}$. Naar verwachting zal de toekomstige verhouding van formeel en informeel in sterke mate afhangen van de economische ontwikkeling èn van de mogelijkheden om sociale arrangementen aan die ontwikkeling parallel te laten lopen.

Wat de formele arbeidsmarkt betreft, is het beeld in Nederland op het ogenblik tweeslachtig. Aan de ene kant is de werkgelegenheid de afgelopen jaren

[2] H. Kroft, G. Engbersen, K. Schuyt en F. van Waarden, Een tijd zonder werk; Leiden/Antwerpen, Stenfert Kroese, 1989.

13] Arm Nederland. Het eerste jaorrapport armoede en sociale uitsluiting, door G. Engbersen, J.C. Vrooman en E. Snel (red.), 's-Gravenhage, VUGA, 1996, bijlage 3.

14] C.C. Koopmans, Informele arbeid; proefschrift Universiteit van Amsterdam, 1989. 
Tabel 2.3 Verblijf in de bijstand naar jaar van instroom voor ABW en voor RWW

\begin{tabular}{|c|c|c|c|c|c|c|c|c|c|c|c|c|c|c|}
\hline \multirow{2}{*}{$\begin{array}{l}\text { ABW-scc } \\
\text { jaar van } \\
\text { instroom }\end{array}$} & \multirow[b]{2}{*}{ instroom } & \multicolumn{13}{|c|}{ jaar van waarneming } \\
\hline & & 1980 & 1981 & 1982 & 1983 & 1984 & 1985 & 1986 & 1987 & 1988 & 1989 & 1990 & 1991 & 1992 \\
\hline 1980 & 29791 & $100 \%$ & $76 \%$ & $59 \%$ & $49 \%$ & $41 \%$ & $35 \%$ & $27 \%$ & $23 \%$ & $21 \%$ & $18 \%$ & $15 \%$ & $13 \%$ & $11 \%$ \\
\hline 1981 & 33192 & & $100 \%$ & $77 \%$ & $59 \%$ & $48 \%$ & $40 \%$ & $31 \%$ & $26 \%$ & $23 \%$ & $20 \%$ & $17 \%$ & $14 \%$ & $13 \%$ \\
\hline 1982 & 36552 & & & $100 \%$ & $80 \%$ & $61 \%$ & $51 \%$ & $39 \%$ & $32 \%$ & $28 \%$ & $24 \%$ & $20 \%$ & $17 \%$ & $15 \%$ \\
\hline 1983 & 40875 & & & & $100 \%$ & $75 \%$ & $58 \%$ & $42 \%$ & $34 \%$ & $30 \%$ & $25 \%$ & $21 \%$ & $18 \%$ & $15 \%$ \\
\hline 1984 & 44104 & & & & & $100 \%$ & $71 \%$ & $48 \%$ & $39 \%$ & $33 \%$ & $27 \%$ & $23 \%$ & $19 \%$ & $16 \%$ \\
\hline 1985 & 39995 & & & & & & $100 \%$ & $64 \%$ & $47 \%$ & $39 \%$ & $32 \%$ & $27 \%$ & $22 \%$ & $19 \%$ \\
\hline 1986 & 44173 & & & & & & & $100 \%$ & $68 \%$ & $48 \%$ & $40 \%$ & $32 \%$ & $27 \%$ & $22 \%$ \\
\hline 1987 & 37077 & & & & & & & & $100 \%$ & $69 \%$ & $53 \%$ & $41 \%$ & $34 \%$ & $28 \%$ \\
\hline 1988 & 37884 & & & & & & & & & $100 \%$ & $69 \%$ & $52 \%$ & $42 \%$ & $34 \%$ \\
\hline 1989 & 37343 & & & & & & & & & & $100 \%$ & $68 \%$ & $52 \%$ & $42 \%$ \\
\hline 1990 & 34395 & & & & & & & & & & & $100 \%$ & $70 \%$ & $53 \%$ \\
\hline 1991 & 35372 & & & & & & & & & & & & $100 \%$ & $71 \%$ \\
\hline \multirow{3}{*}{$\begin{array}{l}\text { RWW } \\
\text { jaar van } \\
\text { instroom }\end{array}$} & \multicolumn{14}{|c|}{ jaar van waarneming } \\
\hline & & & & & & & & & & & & & & \\
\hline & instroom & 1980 & $198 \mid$ & 1982 & 1983 & 1984 & 1985 & 1986 & 1987 & 1988 & 1989 & 1990 & 1991 & 1992 \\
\hline 1980 & 58265 & $100 \%$ & $50 \%$ & $34 \%$ & $26 \%$ & $21 \%$ & $17 \%$ & $14 \%$ & $12 \%$ & $10 \%$ & $8 \%$ & $7 \%$ & $6 \%$ & $5 \%$ \\
\hline 1981 & 62402 & & $100 \%$ & $63 \%$ & $44 \%$ & $35 \%$ & $28 \%$ & $23 \%$ & $19 \%$ & $16 \%$ & $13 \%$ & $11 \%$ & $9 \%$ & $7 \%$ \\
\hline 1982 & 104174 & & & $100 \%$ & $64 \%$ & $45 \%$ & $34 \%$ & $27 \%$ & $21 \%$ & $17 \%$ & $14 \%$ & $11 \%$ & $9 \%$ & $7 \%$ \\
\hline 1983 & 173993 & & & & $100 \%$ & $61 \%$ & $41 \%$ & $30 \%$ & $23 \%$ & $18 \%$ & $14 \%$ & $11 \%$ & $9 \%$ & $7 \%$ \\
\hline 1984 & $16378 \mid$ & & & & & $100 \%$ & $59 \%$ & $39 \%$ & $28 \%$ & $22 \%$ & $17 \%$ & $13 \%$ & $10 \%$ & $8 \%$ \\
\hline 1985 & 151729 & & & & & & $100 \%$ & $59 \%$ & $38 \%$ & $28 \%$ & $20 \%$ & $15 \%$ & $11 \%$ & $9 \%$ \\
\hline 1986 & 125027 & & & & & & & $100 \%$ & $56 \%$ & $36 \%$ & $25 \%$ & $18 \%$ & $13 \%$ & $10 \%$ \\
\hline 1987 & 119657 & & & & & & & & $100 \%$ & $56 \%$ & $35 \%$ & $24 \%$ & $17 \%$ & $12 \%$ \\
\hline 1988 & 125576 & & & & & & & & & $100 \%$ & $53 \%$ & $32 \%$ & $21 \%$ & $14 \%$ \\
\hline 1989 & 110640 & & & & & & & & & & $100 \%$ & $50 \%$ & $30 \%$ & $20 \%$ \\
\hline 1990 & 94343 & & & & & & & & & & & $100 \%$ & $52 \%$ & $31 \%$ \\
\hline 1991 & 91234 & & & & & & & & & & & & $100 \%$ & $53 \%$ \\
\hline
\end{tabular}

Bron: Ministerie van SZW, 1995

sterker gegroeid dan in de meeste andere OESO-landen. Ook de werkloosheidsontwikkeling was, vooral in vergelijking met de continentaal-Europese landen, niet ongunstig. Tegelijkertijd moet worden benadrukt dat deze verbetering zich heeft voltrokken vanuit een bijzonder ongunstige uitgangspositie 15. In internationaal perspectief was de arbeidsparticipatie in Nederland bijzonder laag en het aantal uitkeringsgerechtigden bijzonder hoog. Niet voor niets rekende de OESO voor dat het officiële werkloosheidspercentage van 7 relatief gunstig lag, maar dat de werkloosheid op basis van een bredere definitie uitkwam op 25 procent 16 . De op zichzelf bemoedigende groei van de werkgelegenheid doet derhalve niet af aan het feit dat de arbeidsmarkt nog steeds ernstige problemen kent.

15] Deze kritische situatie heeft de WRR belicht in haar rapport over de scerk achterblijvende arbeidsparticipatie. Zie WRR (1990), op. cir.

16] OESO, Economic Survey The Netherlands 1996; Parijs, 1996, blz. 40-4l. 
Figuur 2.1 Jaarlijkse groei van de bevolking, de bevolking tussen 15 en 65 jaar, de beroepsbevolking en de werkgelegenheid, 1968-1996, op basis van 8-jaars gemiddelden

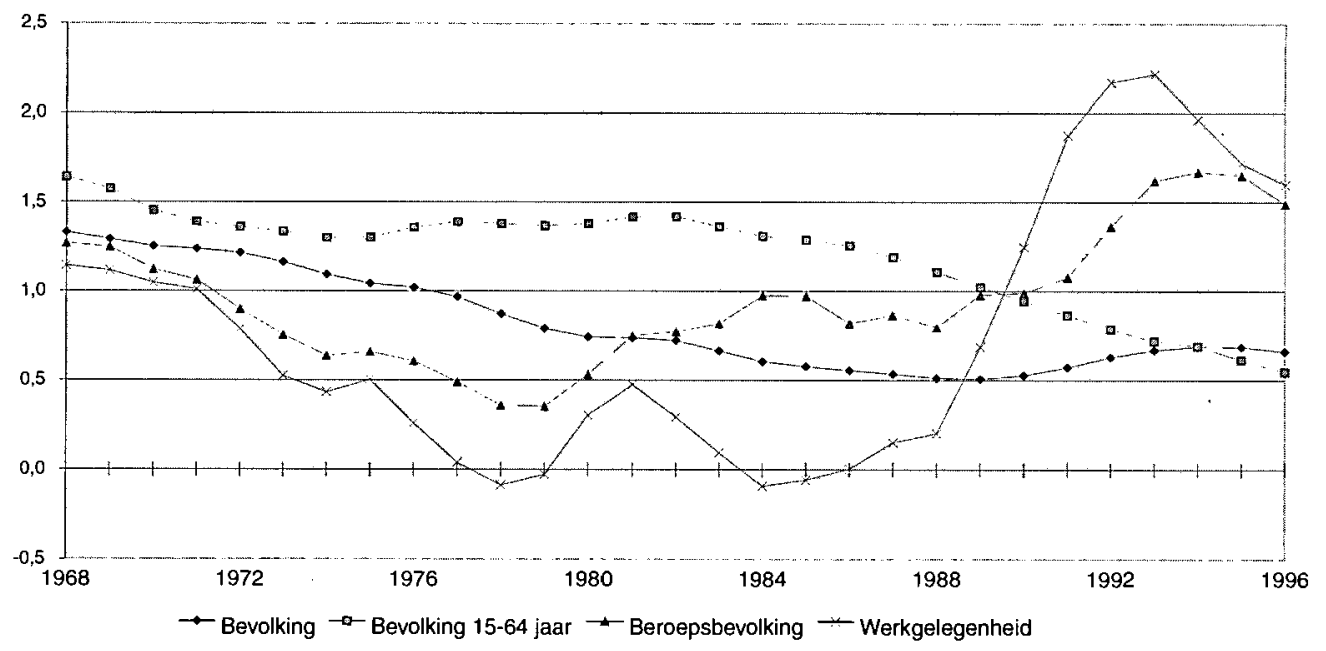

Bron: Eigen berekeningen WRR, op basis van OECD, Economic Outlook nr. 59; juni 1996.

Sinds het einde van de jaren tachtig is er sprake van een omslag op de arbeidsmarkt. Figuur 2.1 laat deze omslag duidelijk uitkomen, aan de hand van de groeipercentages voor de totale bevolking, de bevolking tussen 15 en 65 jaar, de beroepsbevolking en de werkgelegenheid, tussen 1968 en 199617. Om de structurele patronen scherp te krijgen en de conjuncturele invloeden zoveel mogelijk te beperken, worden in de figuur 8-jaars gemiddelden gepresenteerd ${ }^{18}$. Allereerst valt op dat in nagenoeg de hele periode - pas na 1994 komt hierin verandering - de bevolkingsgroep tussen 15 en 65 jaar sneller groeit dan de totale bevolking, een rechtstreeks gevolg van de baby-boom, die Nederland na 1945 heeft gekend. Tot 1990 is de toename van de beroepsbevolking voortdurend hierbij achtergebleven. Dit geldt in nog sterkere mate voor groei van de werkgelegenheid, die rond 1978 en 1983 zelfs negatieve waarden bereikte. Sinds 1985 is er echter weer sprake van groei en op dit moment bedraagt het gemiddelde groeicijfer ruim 1,5 procent, in internationaal perspectief een opvallend hoog percentage.

Ten aanzien van de absolute ontwikkeling van de werkgelegenheid laat figuur 2.2 zien dat de werkgelegenheid in de periode 1970-1985 nauwelijks is veranderd, maar dat sindsdien sprake is van een sterke toename. Die stijging is groter wanneer de werkgelegenheid wordt uitgedrukt in personen dan wanneer die wordt uitgedrukt in arbeidsjaren. De sterke groei van deeltijdarbeid ligt hieraan ten grondslag. In de beschouwde periode is het aantal werkzame mannen nauwelijks toegenomen, terwijl het aantal mannen tussen 15 en 65 jaar tussen 1970 en 1995 met ongeveer 1,2 miljoen steeg. Deze divergentie wordt deels veroorzaakt door de toegenomen deelname aan onderwijsactiviteiten. Daarnaast speelt dat vooral de werknemers boven de 55 jaar in toenemende mate gebruik hebben gemaakt van allerlei uittredingsregelingen, zoals de WW en vooral de WAO en VUT. De werkgelegenheid voor mannen bleef in absolute aantallen dus ongeveer constant. De groei van de totale werkgelegenheid wordt dan nagenoeg volledig gerealiseerd via een hogere arbeidsdeelname van vrouwen ${ }^{19}$. Deze situatie, nauwelijks meer werkzame mannen

17] OESO, Economic Outlook no. 59; juni 1996, gegevens op diskette.

18] Dat komt overeen met de gemiddelde duur van de middellange termijn conjunctuurcyclus.

19] De netto-arbeidsparticipatie van mannen is sterk gedaald, terwijl die bij de vrouwen juist sterk is toegenomen. 
en veel meer werkzame vrouwen, betekent dat het aandeel van mannen in de totale werkgelegenheid gestaag is gedaald.

Figuur 2.2 Omvang werkgelegenheid in personen en arbeidsjaren (x 1000, op linker y-as), alsmede aandeel van mannen in werkgelegenheid in personen (\%, op rechter $Y$-as), 1970-1995

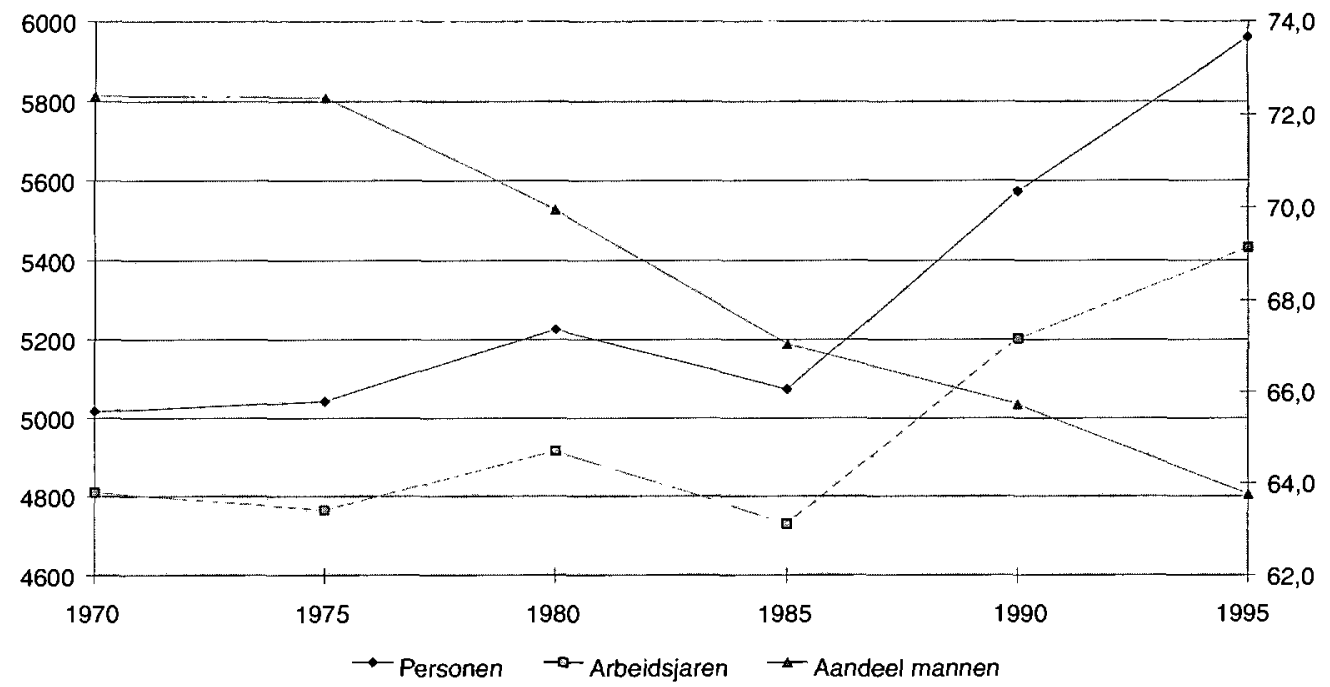

Bron: Eigen berekeningen WRR.

De combinatie van een relatief snel stijgende bevolking en een hierbij achterblijvende groei van de werkgelegenheid leidt tot een dalende ontwikkeling van de arbeidsparticipatie. Dit is weergegeven in figuur 2.3. Zowel de brutoarbeidsparticipatie (de verhouding tussen de beroepsbevolking en de bevolking tussen 15 en 65 jaar) als de netto-arbeidsparticipatie (de werkgelegenheid ${ }^{20}$ ten opzichte van de bevolking tussen 15 en 65 jaar) laten tussen 1968 en 1990 een forse daling zien, waarbij het verschil tussen beide toeneemt. Dit toegenomen verschil weerspiegelt de toegenomen werkloosheid. Pas na 1990 treedt er een herstel op èn wordt het verschil tussen de participatieratio's kleiner. Momenteel ligt de bruto-arbeidsparticipatie op bijna 60 procent, de nettoarbeidsparticipatie op 56 procent en de werkloosheid op 8 procent.

Dit herstel van de werkgelegenheidsgroei, en in een later stadium van de arbeidsparticipatie, is voor een belangrijk deel het gevolg van een langdurig en strak volgehouden loonmatigingsbeleid. Daarnaast lijken ook de herzieningen in de sociale zekerheid zoals die vooral na 1990 in gang zijn gezet en tal van dereguleringsactiviteiten hun vruchten af te werpen. Mede hierdoor heeft de Nederlandse economie de laatste jaren in internationaal perspectief een gunstige ontwikkeling doorgemaakt, met behoorlijke groeicijfers, een intoming van de overheidsuitgaven en een opmerkelijke groei van de werkgelegenheid. Voor de nabije toekomst lijken de vooruitzichten gunstig te blijven; zo verwacht het CPB komend jaar een toename van de werkgelegenheid met meer dan 100.000 banen, dat is met ruim 1,7 procent ${ }^{21}$. Tegelijkertijd blijft gelden dat de Nederlandse economie de afgelopen jaren door een diep dal is

20] Bij de werkgelegenheid worden alleen die banen meegeteld van 12 uur of meer. Daarnaast is er nog een aanzienlijk aantal banen korter dan 12 uur, die echter niet meegerekend worden, maar die voor deze mensen toch arbeidsparticipatie mogelijk maakt. Zouden die in bovenstaande grafiek zijn meegenomen, dan zou de participatie momenteel hoger uitkomen dan eind jaren zestig.

21] Centraal Planbureau, Mocro-Economische Verkenning 1997; 's-Gravenhage, Sdu Uitgeverij, 1996. 


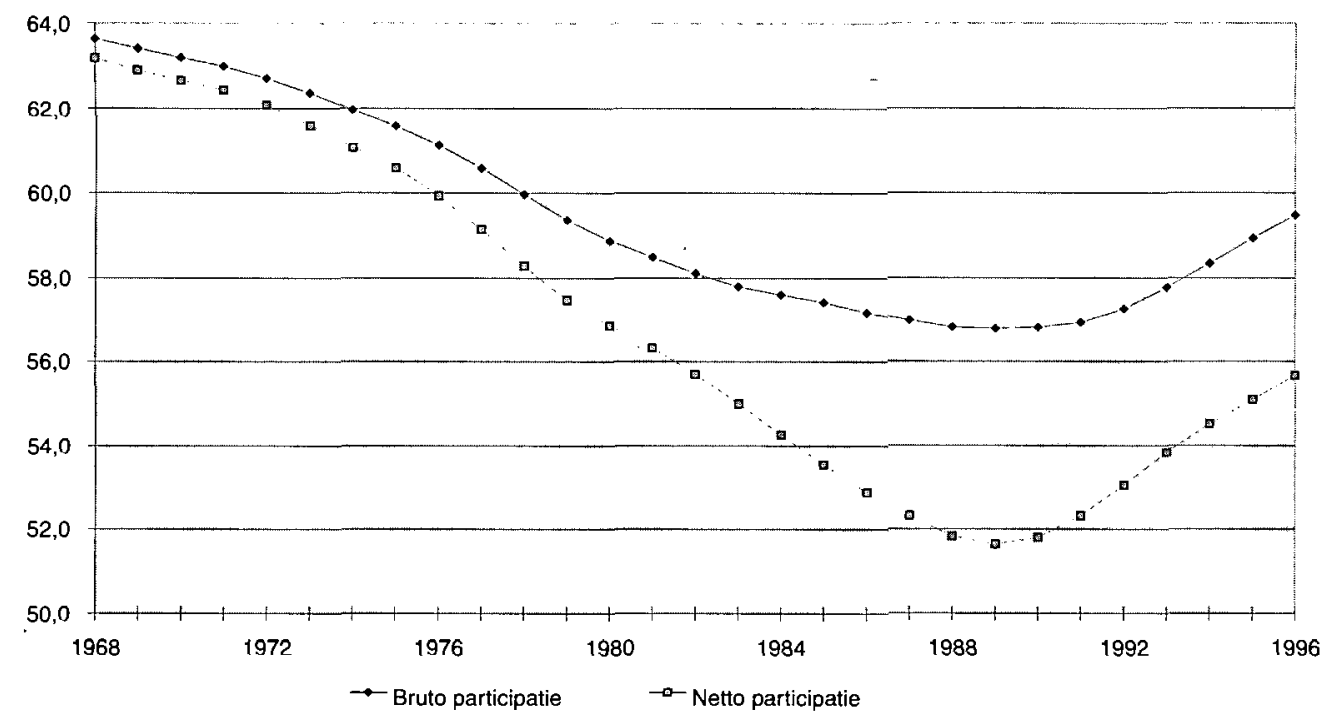

Bron: Eigen berekeningen WRR.

gegaan en dat de verslechtering van de werkgelegenheid zich gedurende wel 20 jaar heeft voltrokken. De negatieve gevolgen daarvan zijn ook zichtbaar in de sociale zekerheid, waar, onder de druk van de omvang van het aantal uitkeringsgerechtigden, de hoogte van de uitkering moest worden aangepakt.

Wat valt nu te zeggen over de kwantitatieve vooruitzichten voor de arbeidsmarkt tot 2015 en de kansen van individuen op deelname aan arbeid? Wat betreft de vraagkant - het aanbod van banen dus - kunnen de drie scenario's van het CPB uit Nederland in Drievoud als referentiepunt worden genomen. In deze scenario's (uit 1991) lopen de voorspellingen voor de werkgelegenheidsgroei (in personen) uiteen van jaarlijks 0,6 tot 1,1 procent. De recente cijfers zijn echter beduidend gunstiger en ook recente berekeningen voor de periode tot 2000 wijzen op een betrekkelijk gunstige ontwikkeling, zelfs op basis van het behoudende scenario 22 . Hierbij wordt aangenomen dat het beleid van loonmatiging voorlopig niet wordt verlaten (pleidooien om dit wel te doen, hebben tot nu toe weinig weerklank gevonden). Meer dreiging zou vanuit de arbeidsmarkt zelf kunnen komen. Naarmate de werkgelegenheidsgroei langer aanhoudt, groeit de kans dat op bepaalde deelmarkten kraptes gaan ontstaan. Hierdoor zou de druk op het hele loongebouw kunnen toenemen. Deze loondruk zou overigens weer kunnen worden weggenomen als in een dergelijke situatie een meer gedifferentieerde loonontwikkeling mogelijk wordt, waardoor tekorten op specifieke arbeidsmarkten kunnen worden weggewerkt.

Op basis van een aantal varianten met betrekking tot de groei van de werkgelegenheid die uiteenlopen van 1,5 procent tot 0,5 procent groei per jaar ${ }^{23}$, is voor dit rapport de werkgelegenheid tot het jaar 2015 berekend. Tabel 2.4 geeft de uitkomsten weer.

22] Centraal Planbureau, Centrool Economisch Plon 1996; 's-Gravenhage, Sdu Uitgeverij, 1996.

23] Zoals eerder al werd aangegeven, bedroeg het gemiddelde groeipercentage van de werkgelegenheid I,7 procent, zelfs met de recessie van de afgelopen jaren daarin opgenomen. 


\begin{tabular}{cccc}
\hline Groei werkgelegenheid & 1995 & 2005 & 2015 \\
\hline 1,5 procent & 6.063 & 7.036 & 8.166 \\
1,25 procent & 6.063 & 6.865 & 7.773 \\
1.0 procent & 6.063 & 6.697 & 7.398 \\
0,5 procent & 6.063 & 6.373 & 6.699 \\
\hline
\end{tabular}

Bron: Eigen berekeningen WRR

De groeipercentages van 1,5 dan wel 1 procent komen overeen met de uitkomsten van de twee middellangetermijnscenario's, gunstig dan wel behoudend, die het CPB tot 2000 heeft doorgerekend ${ }^{24}$. Op basis van 1,5 procent werkgelegenheidsgroei zal de werkgelegenheid oplopen tot ruim 7 miljoen banen in 2005 en tot ongeveer 8,2 miljoen banen in 2015. Bedraagt de jaarlijkse werkgelegenheidsgroei 1 procent, dan resulteert dit in 6,7 respectievelijk 7,4 miljoen banen.

Gegeven de recente ervaringen met werkgelegenheidsgroei, met het sociaaleconomisch beleid en met de toegenomen dynamiek en flexibiliteit in Nederland, lijkt het niet te gewaagd uit te gaan van een groei van 1,25 procent. Deze aanname resulteert in bijna 6,9 miljoen banen in 2005 en 7,8 miljoen in 2015. Tot slot is ook nog een ongunstiger variant doorgerekend, met een werkgelegenheidsgroei van slechts 0,5 procent. Bij deze aanname neemt de werkgelegenheid slechts marginaal toe, tot bijna 6,4 miljoen banen in 2005 en 6,7 miljoen in 2015 .

Voor de ontwikkeling van de aanbodskant zijn de bevolkingsgroei en de arbeidsdeelname per leeftijdsgroep en per geslacht van belang. Voor de bevolkingsontwikkeling is aangesloten bij de Middenvariant van de meest recente CBS-bevolkingsprognose ${ }^{25}$. Voor de arbeidsdeelname zijn twee varianten uitgewerkt. In het eerste geval (hier de MIN-variant genoemd) wordt verondersteld dat het arbeidsaanbod per leeftijdsgroep nauwelijks meer zal veranderen, met dien verstande dat het arbeidsaanbod van vrouwen vanwege het cohorteffect zeker in het begin nog wel zal toenemen. Verondersteld wordt dat het arbeidsaanbod van oudere mannen niet zal veranderen. Het beroep van deze groep op een pensioen- dan wel socialezekerheidsvoorziening zal dus onverminderd hoog blijven. In de PLUS-variant wordt er daarentegen van uitgegaan dat het arbeidsaanbod van deze groep mannen weer opgetrokken zal kunnen worden naar niveaus die vóór 1980 nog gerealiseerd werden. Bij het arbeidsaanbod van vrouwen wordt verondersteld dat de huidige ontwikkelingen doorgaan ${ }^{26}$. Uitgangspunt voor de berekeningen voor tabel 2.5 vormen de participatiecijfers naar leeftijd en geslacht, zoals vermeld in de EBB-1995 ${ }^{27}$.

24] De daarin opgenomen groeicifers voor de werkgelegenheid bedragen 1.5 procent voor het gunstige en I procent voor het behoudende scenario. Zie: Centraal Planbureau (1992), op. cit., tabel V.6.I.

25] Centraal Bureau voor de Statistiek, Bevolkings- en Huishoudensprognose 1995; Maandstatistiek van de Bevolking, 1996, jrg. 44, nr. I, blz. 6-9.

26] Ten opzichte van de arbeidsparticipatiegegevens voor 2005 en 2015 komen de uitkomsten van de PLUS-variant redelijk met die van de BG- en EUR-scenario's van het CPB overeen. Afwijkend zijn de percentages voor de leeftijdsgroep tussen 45 en 55 jaar, die bij het CPB lager liggen. De WRR veronderstelt dat het cohorteffect zodanig zal zijn, dat de arbeidsparticipatie van deze groep de komende jaren sterk zal toenemen. Zie: Centraal Planbureau (1992), op. cit., blz. 150.

${ }^{27}$ Centraal Bureau voor de Statistiek, op. cit., tabel 2. 
Tabel 2.5 Ontwikkeling van het arbeidsaanbod (bruto-arbeidsparticipatie) voor mannen en vrouwen, 1987-2015

\begin{tabular}{ccccccccc}
\hline Leeftijd & \multicolumn{3}{c}{ MIN-Variant } & & & \multicolumn{2}{c}{ PLUS-variant } \\
\hline Mannen & 1987 & 1995 & 2005 & 2015 & 1987 & 1995 & 2005 & 2015 \\
\hline $15-24$ & 49 & 46 & 42 & 38 & 49 & 46 & 44 & 44 \\
$25-34$ & 92 & 93 & 93 & 93 & 92 & 93 & 94 & 95 \\
$35-44$ & 93 & 95 & 94 & 94 & 93 & 95 & 95 & 96 \\
$45-54$ & 84 & 89 & 90 & 90 & 84 & 89 & 92 & 94 \\
$55-64$ & 45 & 40 & 40 & 40 & 45 & 40 & 46 & 54 \\
\hline Vrouwen & 1987 & 1995 & 2005 & 2015 & 1987 & 1995 & 2005 & 2015 \\
\hline $15-24$ & 46 & 43 & 40 & 37 & 46 & 43 & 42 & 42 \\
$25-34$ & 52 & 68 & 72 & 75 & 52 & 68 & 85 & 92 \\
$35-44$ & 44 & 58 & 65 & 68 & 44 & 58 & 72 & 8 \\
$45-54$ & 33 & 47 & 60 & 66 & 33 & 47 & 65 & 75 \\
$55-64$ & 11 & 14 & 14 & 14 & 11 & 14 & 18 & 22 \\
\hline
\end{tabular}

Bron: Eigen berekeningen WRR

Zoals uit tabel 2.5 valt af te lezen, zijn bij de mannen de veranderingen èn de verschillen tussen de twee varianten gering. In de PLUS-variant daalt het arbeidsaanbod bij de leeftijdsgroep tot 25 jaar niet verder, en is de toename bij de oudere werknemers groter. Bij de overige leeftijdsgroepen zijn de verschillen beperkt. Bij de vrouwen lopen de twee varianten wel sterker uiteen. Terwijl in de MIN-variant de toename van het arbeidsaanbod al snel stabiliseert, wordt er in de PLUS-variant van uitgegaan dat het arbeidsaanbod ook de komende jaren zal blijven toenemen, niet alleen vanwege de nog steeds toenemende onderwijsdeelname van vrouwen, maar ook vanwege het voortgaande cohorteffect. Met dit laatste wordt gedoeld op het gegeven dat de jaargangen vrouwen die na 1970 op de arbeidsmarkt kwamen, nu ook in de oudere leeftijdsgroepen beginnen voor te komen, hetgeen duidelijke gevolgen heeft voor het arbeidsaanbod. In de PLUS-variant nemen de verschillen tussen mannen en vrouwen hierdoor af. De arbeidsparticipatie in 2015 volgens het PLUS-scenario komt overeen met de situatie zoals die nu al bestaat in landen die een hoge arbeidsparticipatie van vrouwen kennen. Vooruitlopend op het volgende hoofdstuk, waar nader stilgestaan wordt bij de opleidings- en arbeidsmarktparticipatie van vrouwen, kan worden gesteld dat de PLUSvariant waarschijnlijker is dan de MIN-variant.

Op basis van deze informatie is vervolgens een globale berekening gemaakt van de werkgelegenheidssituatie tot 2015 en de daarbij behorende werkloosheid en non-participatie. Uitgangspunt is de CBS-midden bevolkingsprognose en een ontwikkeling van de arbeidsdeelname volgens de PLUS-variant. Vervolgens is de werkgelegenheid volgens de vier mogelijkheden - een jaarlijkse groei van 1,5, 1,25, 1,0 en 0,5 procent - doorgerekend. De uitkomsten voor de werkloosheid zijn weergegeven in figuur 2.4 .

$\mathrm{Bij}$ een werkgelegenheidsgroei van 1,25 procent zal de werkloosheid tot 2000 licht stijgen, maar in de daarop volgende jaren dalen tot onder de 6 procent na 2010 . Komt de groei van de werkgelegenheid uit boven 1,25 procent, dan zal de werkloosheid al direct gaan dalen. Bij een werkgelegenheidsgroei van 1 procent zal de werkloosheid in eerste instantie forser stijgen, maar ook dan zal na 2000 toch een daling intreden. Zou de werkgelegenheidsgroei nog lager liggen, op 0,5 procent, dan loopt de werkloosheid op tot 15 procent. 


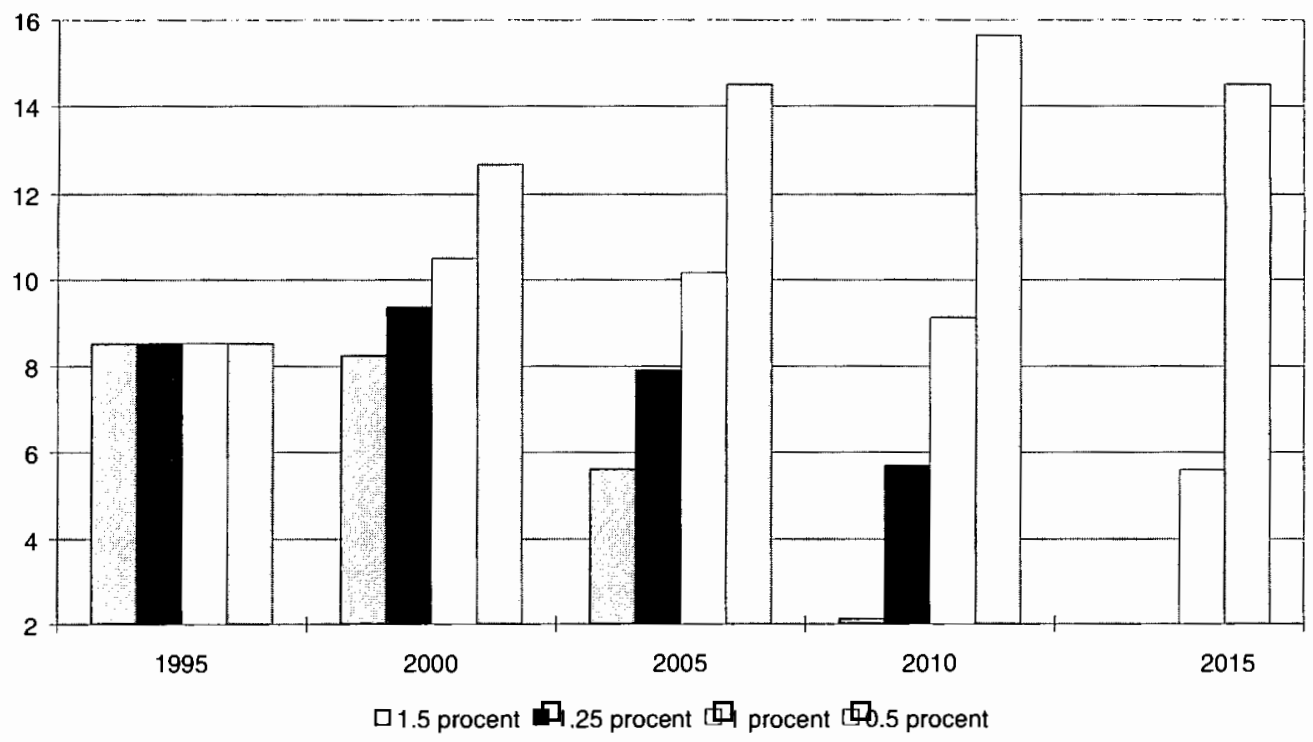

Bron: Eigen berekeningen WRR.

De toegankelijkheid van de arbeidsmarkt zal bij een werkgelegenheidsgroei van 1,25 procent belangrijk toenemen (zie fig. 2.5). Dit geldt, maar in mindere mate, ook nog wanneer de werkgelegenheid groeit met 1 procent. Zou de werkgelegenheidsgroei hoger uitkomen, dan wordt het perspectief gunstiger. Blijft de groei van de werkgelegenheid echter steken op jaarlijks 0,5 procent, dan verandert de non-participatie de komende jaren niet of nauwelijks. Juist deze laatste bevinding maakt eens te meer duidelijk dat ook in de overzienbare toekomst alle inspanningen ter verbetering van de arbeidsmarkt voortgezet moeten worden.

Figuur 2.5 Mate van non-participatie bij verschillende groeipercentages van de werkgelegenheid, 1995-2015

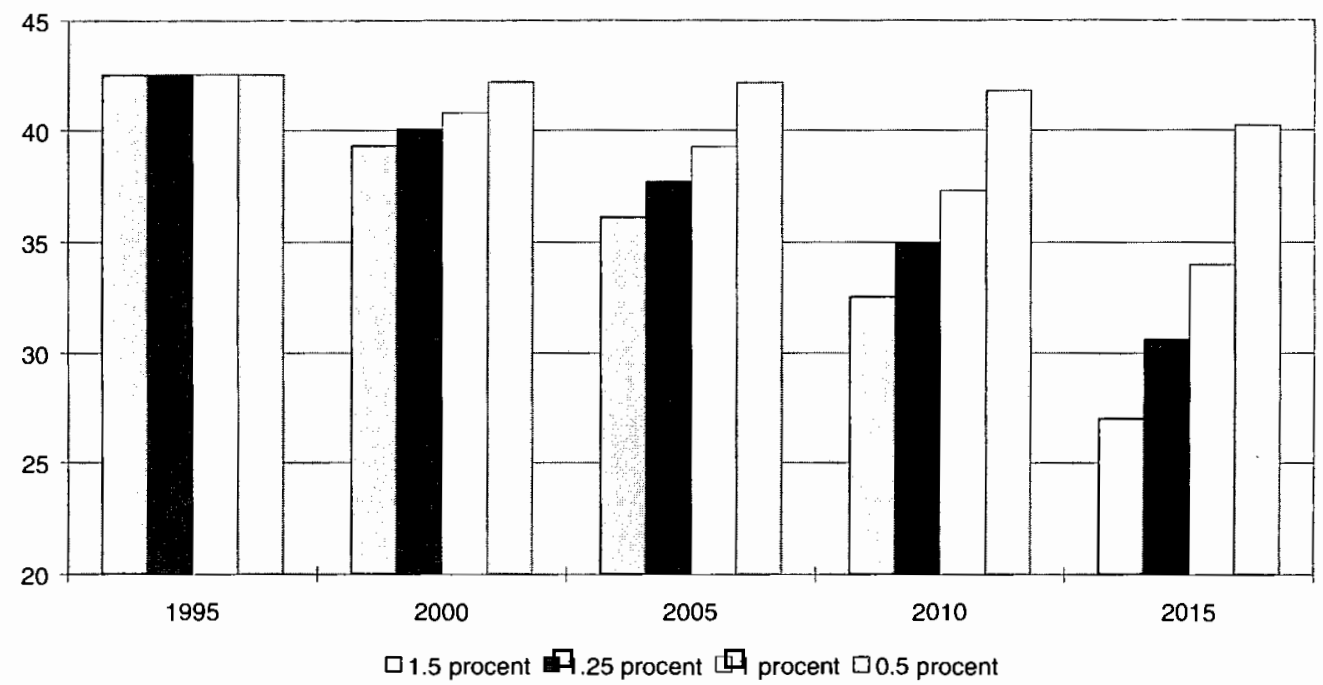

Bron: Eigen berekeningen WRR. 
Wanneer het arbeidsaanbod zich overeenkomstig de MIN-variant zou ontwikkelen, zijn de verwachtingen voor de werkloosheid in alle gevallen gunstiger. In dit geval zou het beleid wellicht minder nadruk op de groei van de werkgelegenheid willen leggen. Dit zou er echter aan voorbijgaan dat de arbeidsparticipatie relatief laag blijft, en dus de non-participatie en het beroep op de sociale zekerheid hoog. Aangezien er juist naar wordt gestreefd de non-participatie terug te dringen, is deze ontwikkeling minder wenselijk. Zou de bevolkingsgroei hoger uitkomen, dan worden ook de werkloosheid en de non-participatie hoger. Ook hier treedt echter na 2005 een daling op. Zou in dat geval de jaarlijkse werkgelegenheidsgroei opgekrikt kunnen worden naar 1,5 procent, dan levert dit een relatief gunstig ontwikkelingspatroon op, met meer werkgelegenheid, een lage werkloosheid en een lage non-participatie.

Duidelijk zal zijn dat het bij de voornoemde ontwikkelingen om een langdurig proces gaat. De aantasting van de arbeidsmarkt en het uit de hand lopen van de sociale zekerheid hebben jaren geduurd; het herstel zal ook veel tijd vergen. In dit perspectief kan worden geconcludeerd dat een forse groei van de werkgelegenheid noodzakelijk maar ook mogelijk is. Noodzakelijk om voldoende nieuwe banen te scheppen voor de groeiende bevolking, noodzakelijk ook vanwege de maatschappelijke betekenis van arbeidsparticipatie, de toenemende pensioenlasten en om de sociale zekerheid te kunnen blijven financieren. Mogelijk is het als het huidige beleid, van loonmatiging, aanpassing van de sociale zekerheid, deregulering en flexibilisering, wordt voortgezet. Tegelijk kan niet worden ontkend dat zelfs in het geval dat de arbeidsparticipatie fors kan worden verhoogd en de werkloosheid en de non-participatie sterk verlaagd, de laaggeschoolden nog steeds in een zwakke positie op de arbeidsmarkt zullen verkeren.

\subsubsection{Scheefheid van de verdeling}

Naast verschuivingen in de betekenis van en de toegang tot het te verdelen goed 'beroep' zijn er ook verschuivingen waar te nemen met betrekking tot de kwaliteiten van de beroepsbeoefenaren. Dat de eisen in de loop van de tijd anders komen te liggen, laat zich raden. Of deze eisen gemiddeld ook hoger zijn geworden, is echter de vraag. Vaak wordt gesuggereerd dat de ontwikkeling van economie en technologie tot een algemene opwaardering of regradatie van functie-inhoud leidt. Een dergelijke suggestie zou passen bij de waarneming dat laaggeschoolden het moeilijker krijgen om een plaats op deze verdelingsdimensie te bemachtigen. Dit wekt de indruk dat de beroepenverdeling relatief steeds meer complexe, moeilijke, zelfstandigheid eisende functies gaat omvatten en steeds minder eenvoudig en routineus werk. Daarmee zou in toenemende mate sprake zijn van scheefheid van de beroepenverdeling.

In de literatuur worden drie mogelijke tendenties onderscheiden bij de niveau-ontwikkeling van de arbeid. De eerste betreft een toename van zowel de kwalitatief hoogwaardige als de kwalitatief laagwaardige banen. Dit gaat ten koste van de middencategorie van banen, zodat een polarisatie resulteert. De tweede tendentie betreft een algemene opwaardering van functies op alle niveaus, een regradatie. Functies van een laag niveau verdwijnen en functies op een hoog niveau nemen toe. De derde mogelijkheid betreft een algemene afwaardering van het functieniveau, een degradatie. Het zal niet verbazen dat in de waargenomen ontwikkeling van de functieniveaustructuur van de werkzame beroepsbevolking soms op hetzelfde moment tegengestelde tendenties kunnen worden onderkend. Uiteindelijk is er vaak sprake van een pluriforme ontwikkeling. Steijn en De Witte concluderen naar aanleiding van een door hen uitgevoerd onderzoek dat, onder invloed van automatisering, wel kan worden gesproken van een zekere regradatie van functie-inhoud als het gaat om hoofdarbeiders, maar zeker niet waar het handarbeiders betreft. Binnen 
een algemeen beeld van lichte regradatie zijn het juist de handarbeiders die zich een zekere mate van degradatie moeten laten welgevallen ${ }^{28}$.

In de Nederlandse functieniveaustructuur zijn in de loop der tijd opmerkelijke verschuivingen waar te nemen. In tabel 2.6 is de ontwikkeling in het werkgelegenheidsaandeel naar functieniveau volgens de indeling van Huijgen gegeven. Ongeschoolde beroepen behoren tot klasse 1 , half geschoolde en geoefende beroepen tot klasse 2, geschoolde beroepen tot klasse 3 en 4 en gespecialiseerde beroepen behoren tot de klassen 5, 6 en 7 .

Tabel 2.6 Werkgelegenheid naar functieniveau (percentages)

\begin{tabular}{lccccc}
\hline Functieniveau & 1960 & 1971 & 1977 & 1985 & 1991 \\
\hline 1 & 8 & 11 & 8 & 9 & 8 \\
2 & 19 & 21 & 28 & 20 & 15 \\
3 & 26 & 22 & 20 & 22 & 21 \\
4 & 30 & 21 & 19 & 20 & 20 \\
5 & 6 & 13 & 12 & 14 & 13 \\
6 & 8 & 10 & 9 & 10 & 16 \\
7 & 1 & 3 & 4 & 6 & 6 \\
\hline
\end{tabular}

Bron: Sociaal en Cultureel Planbureau, Sociale en Culturele Verkenningen 1995; Rijswijk, 1995.

F. Huijgen, De kwalitatieve structuur van de werkgelegenheid in Nederland Deel III; OSA Voorstudie V33, 's-Gravenhage, 1989.

G.J.M. Conen, F. Huijgen en B.J.P. Riesewijk, 'De kwalitatieve structuur van de werkgelegenheid in 1960, 1971, en 1977'; Economisch Statistische Berichten, jrg. 68, 27 april 1983.

Van 1960 tot 1971 treedt polarisatie op. Het aandeel van de twee laagste en de drie hoogste functieniveaus neemt toe; dat van de tussenliggende functieniveaus neemt af. Van 1971 tot 1977 is er alleen nog sprake van degradatie: het aandeel van de twee laagste functieniveaus neemt toe. Na 1977 doet zich regradatie voor: het aandeel van de laagste twee functieniveaus neemt af en het aandeel van de hogere functieniveaus neemt toe. Een kanttekening die moet worden gemaakt, is dat de beroepenclassificatie waarop de functieniveau-indeling gebaseerd is, voor de latere jaren is verouderd.

De regradatie in de afgelopen periode komt ook naar voren in de nieuwe beroepsniveau-indeling van het CBS (tabel 2.7).

Tabel 2.7 Beroepsbevolking naar beroepsniveau (procenten)

\begin{tabular}{cccccc}
\hline & elementair & lager & middelbaar & hoger & wetenschappelijk \\
\hline 1985 & 7 & 34 & 39 & 15 & 5 \\
1994 & 6 & 27 & 41 & 19 & 7 \\
\hline
\end{tabular}

Bron: CBS, Enquête Beroepsbevolking.

Uit een nadere analyse blijkt dat veranderingen in de functieniveaustructuur van de beroepsbevolking hoofdzakelijk zijn terug te voeren op veranderingen in de sectorstructuur en veranderingen in de beroepenstructuur, waarbij de laatste het grootste gewicht hebben. Veranderingen in de beroepenstructuur kunnen worden nagelopen aan de hand van vijf brede categorieën: kennis- 
arbeid, leidinggevende arbeid, administratieve arbeid, dienstenarbeid en productie-arbeid. Het aandeel van kennisarbeid is in veel sectoren toegenomen, het aandeel van administratieve arbeid is in de sector bank- en verzekeringswezen en zakelijke dienstverlening duidelijk afgenomen en het aandeel van productie-arbeid is met name in de industriesectoren gedaald. Voor de overige twee categorieën is het beeld diffuus. $\mathrm{Nu}$ is in het algemeen gesproken administratieve arbeid vatbaar voor kantoorautomatisering en productie-arbeid voor industriële automatisering. De conclusie ligt dus voor de hand dat technologische en organisatorische ontwikkelingen de functieniveaustructuur hebben beïnvloed.

Uit onderzoek in de Verenigde Staten, waar een vergelijkbare regradatietendens in de functieniveaustructuur is waar te nemen, blijkt dat meer dan 40 procent van de variatie in de loonsomverhouding tussen de verschillende functiecategorieën is toe te schrijven aan investeringen in computers 29 . Nederlands onderzoek wijst uit dat technologische vooruitgang in brede zin heeft geleid tot vermindering van de vraag naar laaggeschoolde arbeid ten opzichte van de vraag naar hooggeschoolde arbeid; dit in zowel de exposed sector als de sheltered sector ${ }^{30}$. Tegelijk blijkt de productiviteitsstijging van hooggeschoolde werknemers in beide sectoren groter te zijn dan die van laaggeschoolde werknemers. De hoge productiviteitsstijging van hooggeschoolde werknemers leidt in eerste instantie tot een geringe vraag naar deze werknemers. Tegenover dit effect staat echter dat de prijs van hooggeschoolde arbeid, gecorrigeerd voor de productiviteit, daalt. Dit leidt ertoe dat laaggeschoolde arbeid door hooggeschoolde wordt vervangen. Het effect van deze vervanging op de vraag naar hooggeschoolde werknemers overtreft het effect dat de productiviteitsstijging van deze werknemers in eerste instantie op de vraag heeft. Voor laaggeschoolde arbeid geldt de omgekeerde redenering. De vraag naar dit type arbeid neemt af als gevolg van de technische ontwikkeling. Weliswaar is de productiviteitsstijging van deze werknemers relatief gering, maar hier staat tegenover dat de voor productiviteitsmutaties gecorrigeerde prijsstijging van laaggeschoolde arbeid relatief hoog is; laaggeschoolde werknemers worden dan door hooggeschoolde vervangen.

Ander Nederlands onderzoek, dat specifiek ingaat op de gevolgen van automatisering voor de functieniveaustructuur, relativeert het determinisme in deze relatie ${ }^{31}$. Er wordt gesteld dat de kans op regradatie groter is naarmate de automatisering complexer en langduriger is, en naarmate er meer inbreng is geweest van gebruikers of externe deskundigen. Een meer recent onderzoek laat een verband zien tussen automatisering en functie-inhoud bij onderscheiden categorieën van arbeid 32 . Als uitgangspunt is gehanteerd dat het niveau van de functie-inhoud in grote mate wordt bepaald door de grootheden complexiteit en autonomie. Geconstateerd wordt dat automatisering zowel bij kennisarbeid als bij administratieve arbeid door de bank genomen de complexiteit of de autonomie doet toenemen en daarmee tot regradatie leidt. Bij handarbeid (productie-arbeid en dienstenarbeid) geldt een ander patroon. Daar leidt automatisering eerder tot een toename van de complexiteit en een afname van de autonomie. Dit valt niet als regradatie te duiden. Deze tegengestelde bewegingen worden door de onderzoekers 'interne differentiatie' genoemd. Voor leidinggevende hoofdarbeid worden geen significante verban-

${ }^{29}$ ] E. Bergman, J. Bound, Z. Griliches, 'Changes in the Demand for Skilled Labor within U.S. Manufacturing: Evidence from the Annual Survey of Manufactures'; The Quarerty journal of Economics, May 1994, blz. 365-397.

30] N. Draper, T. Manders, Structural changes in the demand for labor, Centraal Planbureau, Research Memorandum no. 128 , 's-Gravenhage, 1996.

31] R.S. Batenburg, Automotisering in bedrijf, Amsterdam, Thesis Publishers, 1991.

32] Steijn en De Witte, op. cit. 
den gevonden; leidinggevende handarbeid blijkt net als de overige handarbeid aan het proces van interne differentiatie onderworpen te zijn.

De vraag blijft echter of de lichte regradatie van functies en beroepen niet ook een artefact is van de uitstoot van relatief eenvoudig 'ongeschoold' werk, waarvoor, gegeven de huidige regelingen, de loonkosten niet meer in de pas lopen met de geleverde arbeidsprestatie. Hiermee zou regradatie eerder verwijzen naar het 'informaliseren' van laagwaardige arbeid dan naar een opwaardering in niet 'geïformaliseerde' functies en beroepen. Vooralsnog lijkt het verstandig om met het mogelijk kosmetische karakter van de regradatiesuggestie rekening te houden. Want het is onmiskenbaar dat onder de onderkant van de huidige verdeling van functies en beroepen nog een verdeling van informele functies en activiteiten bestaat, waarvoor meestal met een lage scholingsgraad kan worden volstaan. Met name in de horeca en in de gezondheidszorg is het werkgelegenheidsaandeel in Nederland opmerkelijk lager dan in de landen met een hogere algemene arbeidsparticipatie, zoals de Verenigde Staten en Zweden 33. Dit zou erop kunnen wijzen dat de lager gekwalificeerde arbeid binnen die sectoren in Nederland in belangrijke mate is weggerationaliseerd en in een aantal gevallen in het informele circuit is terechtgekomen.

De confrontatie van de in deze paragraaf gemaakte opmerkingen over veranderingen in functieniveau met de arbeidsmarktprojecties van de vorige paragraaf noopt tot een nadere nuancering. De projecties van de werkloosheid in paragraaf 2.2.2 leverden geen somber beeld op. Vraag en aanbod van arbeid werden er echter als homogene grootheden gezien. Nu kan ook het beroepsniveau in de vraag naar arbeid betrokken worden en kan de aansluiting bij het scholingsniveau van het arbeidsaanbod worden nagegaan. In tegenstelling tot de vorige paragraaf wordt hier niet de bruto- maar de netto-arbeidsparticipatie belicht. Aan de orde is de vraag welke ontwikkelingen er in de nettoarbeidsparticipatie per opleidingsniveau te verwachten zijn. Terloops komen ook te verwachten veranderingen in de aandelen van de verschillende arbeidscategorieën ter sprake. Momenteel concentreert veel van de werkloosheidsproblematiek zich aan de onderkant van de arbeidsmarkt. Het is de vraag of dat zich in de toekomst zal oplossen.

De hier gepresenteerde projectie is enerzijds gebaseerd op een voortgaande toename van de onderwijsparticipatie, zoals neergelegd in de Referentieramingen van het Ministerie van Onderwijs, Cultuur en Wetenschappen. Anderzijds is de projectie gebaseerd op een ontwikkeling van de vraag naar arbeid die voortkomt uit een trendmatig verloop van economische kencijfers als arbeidsproductiviteiten, P/A-ratio's en contractuele arbeidsduur, en uit een trendmatige verschuiving in het consumptiepatroon en in de sectorale beroepsniveaustructuur. Op basis van deze economische structuurelementen is de arbeidsvraag doorgerekend in een rekenschema waarin zeven sectoren zijn onderscheiden. De mate waarin vraag en aanbod aansluiten op de arbeidsmarkt, is op de lange termijn vooral afhankelijk van de mate van economische groei die gerealiseerd wordt. In het rekenschema wordt die economische groei beperkt door de ruimte die een trendmatige loonstijging voor investeringen in de verschillende sectoren overlaat.

Over de mate van aansluiting van het arbeidsaanbod bij de arbeidsvraag kunnen, zelfs op het hoge aggregatieniveau dat hier gehanteerd wordt, meerdere opvattingen naast elkaar bestaan. In menige functieclassificatie is het feitelijk gevolgde onderwijs mede bepalend voor het functieniveau. Hiermee is de aansluiting van scholingsniveau op functieniveau in feite onbepaald. In de 
nieuwe beroepenclassificatie van het CBS is gepoogd die definitorische afhankelijkheid te vermijden. Voor alle beroepen is door arbeidsdeskundigen het meest geëigende onderwijsniveau bepaald. Verondersteld wordt dat het oordeel van deze deskundigen los staat van de feitelijke arbeidsmarktsituatie. Volgens deze methodiek is dan te berekenen of de arbeidsvraag op een bepaald beroepsniveau aansluit bij het aanbod van het meest geëigende onderwijsniveau, in termen van een nettoparticipatiegraad. Er kan ook nog sprake zijn van verdringing op de arbeidsmarkt of van het tegenovergestelde, namelijk dat arbeidsplaatsen door in onvoldoende mate geschoolden worden vervuld. Van dit feit wordt bij deze berekening geabstraheerd.

De projectie laat aan de vraagzijde zien dat de werkgelegenheid stagneert op de elementaire en lagere beroepsniveaus en groeit op de middelbare, hogere en wetenschappelijke beroepsniveaus: Aan de aanbodzijde daalt, door de intensivering van de onderwijsparticipatie en door cohorteffecten, de bevolking buiten voltijdonderwijs (BBVO) zonder diploma's. Maar door de toegenomen onderwijsparticipatie stijgt de BBVO met uitgebreid lager onderwijs.

Tabel 2.8 Samenstelling van de arbeidsvraag naar beroepsniveau

(x 1000 personen)

\begin{tabular}{lccccc}
\hline & elementair & laag & middelbaar & hoog & wetenschappelijk \\
\hline 1995 & 415 & 1683 & 2595 & 1256 & 502 \\
2000 & 448 & 1665 & 3009 & 1606 & 643 \\
2005 & 451 & 1597 & 3365 & 1993 & 804 \\
2010 & 458 & 1433 & 3415 & 2124 & 829 \\
\hline
\end{tabular}

Bron: Eigen berekeningen WRR.

Tabel 2.9 Bevolking buiten voltijd onderwijs 15-65 jaar (x 1000 personen)

\begin{tabular}{lrrrr}
\hline & 1995 & 2000 & 2005 & 2010 \\
\hline Basis & 1368 & 1221 & 1117 & 1043 \\
Uitgebreid lager algemeen & 885 & 962 & 1023 & 1080 \\
Uitgebreid lager beroeps & 1861 & 1881 & 1875 & 1871 \\
Middelbaar algemeen & 443 & 485 & 521 & 554 \\
Middelbaar beroeps & 3130 & 3202 & 3236 & 3222 \\
Semi hoger & 1273 & 1392 & 1490 & 1563 \\
Hoger & 537 & 629 & 712 & 782 \\
\hline
\end{tabular}

Bron: Ministerie van Onderwijs en Wetenschappen, Referentieraming 1994.

De vraag naar beroepsniveau en het aanbod naar meest geëigend onderwijsniveau sluiten als volgt op elkaar aan ${ }^{34}$. Voor het elementaire beroepsniveau is het lager onderwijs het meest geëigend, en voor het lagere beroepsniveau lager onderwijs met enige werkervaring of voortgezet onderwijs in de lagere trap. Bij het middelbare beroepsniveau past voortgezet onderwijs in de lagere trap met werkervaring of voortgezet onderwijs in de hogere trap. Voor het hogere beroepsniveau is voortgezet onderwijs in de hogere trap met werkervaring het meest toepasselijk of hoger onderwijs in de eerste fase, terwijl het wetenschappelijke beroepsniveau hoger onderwijs in de eerste fase met werkervaring vraagt, of hoger onderwijs in de tweede fase. De twee laagste onderwijscategorieën zijn dus grosso modo het meest geëigend voor de twee laagste

${ }^{34}$ ] B.F.M. Bakker, 'De CB5 Standaard Beroepenclassificatie 1992'; Tijdschrift voor Arbeidsvraogstukken, 1994, jrg. 10, nr. 4. 
beroepsniveaus. Helaas is de nettoparticipatie van de laagste twee onderwijscategorieën momenteel laag. In de projectie blijft dit ook zo. De vraag naar hogere beroepsniveaus en het aanbod van hogere onderwijsniveaus stijgen beide. Met de economische groei - in deze projectie gesteld op gemiddeld 2,5\% stijgt de nettoparticipatie van al deze hogere onderwijsniveaus.

Tabel 2.10 Samenstelling van de arbeidsvraag naar arbeidscategorieën (x 1000 personen)

\begin{tabular}{cccccc}
\hline & kennisarbeid & leidinggevend & administratief & dienstenarbeid & productie-arbeid \\
\hline 1995 & 1384 & 646 & 1121 & 1763 & 1535 \\
2000 & 1760 & 723 & 1316 & 2005 & 1603 \\
2005 & 2178 & 801 & 1442 & 2161 & 1667 \\
2010 & 2303 & 814 & 1394 & 2137 & 1646 \\
\hline
\end{tabular}

Bron: Eigen berekeningen WRR.

Het is ten slotte mogelijk een indruk te geven van de mate waarin de toenemende arbeidsvraag in de verschillende categorieën van arbeid zal neerslaan. Tabel 2.10 laat zien dat met name de kennisarbeid naar verwachting fors zal stijgen. De lager opgeleiden zullen voornamelijk emplooi vinden in de categorieën dienstenarbeid en productie-arbeid.

Deze bevindingen nuanceren het gunstige beeld voor de werkgelegenheidsontwikkeling, zoals dit in de subparagraaf hiervoor was geschetst. Het herstel van de werkgelegenheid komt niet gelijkmatig ten goede aan het arbeidsaanbod. Vooralsnog profiteren vooral de beter geschoolden ervan en blijft de arbeidsmarktpositie van de lager opgeleiden zwak. Ondanks de positieve economische en arbeidsmarktontwikkeling, blijft de werkloosheid onder laaggeschoolden dan ook hoog 35 .

\subsubsection{Openheid en mobiliteit}

Inter- en intrasectorale verschuivingen op de arbeidsmarkt zullen naar verwachting ook in de nabije toekomst voortgaan. Deze dynamiek stelt eisen aan het aanpassingsvermogen van werknemers en doet het belang toenemen van functionele mobiliteit gedurende de beroepsloopbaan. Maar hoe dynamisch is arbeid?

De groei van de werkgelegenheid met gemiddeld 1,7 procent gedurende de afgelopen tien jaar geeft een indicatie van dynamiek. De werkelijke omvang van deze dynamiek komt echter vooral naar voren in de onderliggende in- en uitstroom op de arbeidsmarkt. Uit een onderzoek op basis van het arbeidsvraagpanel van de Organisatie voor Strategisch Arbeidsmarktonderzoek (OSA) blijkt bijvoorbeeld dat de instroom en uitstroom van werknemers in bedrijven ruim tienmaal zo groot is als de nettowerkgelegenheidsverandering ${ }^{36}$. Dit is weergegeven in tabel 2.11 .

35] Zie: P. de Beer, Het onderste kwart. Werk en werkloosheid oan de onderkant van de arbeidsmarkt; Rijswijk, SCP, 1996, hfdst. 4. 36] W. Hassink en J. van Ours, Werkgelegenheid in verandering; OSA-Werkdocument WI22, 's-Gravenhage, 1994. 


\begin{tabular}{lccc}
\hline & $\begin{array}{l}\text { Negatieve component } \\
\text { (Uit) }\end{array}$ & $\begin{array}{l}\text { Positieve component } \\
\text { (In) }\end{array}$ & Totaal \\
\hline Werkgelegenheidsverandering & & & 1,8 \\
Bruto reallocatie van werkgelegenheid & 2,2 & 4 & 6,2 \\
Baanstromen & 2,6 & 4,4 & 7 \\
Werknemersstromen & 10,1 & 11,9 & 22 \\
\hline
\end{tabular}

Bron: W. Hassink en J.C. van Ours, Werkgelegenheid in verandering; OSA-Werkdocument W122, Den Haag, 1994.

In tabel 2.11 wordt een onderscheid gemaakt tussen de verandering van het aantal banen en het aantal mensen dat van baan verandert. Het totale verlies van werkgelegenheid in bedrijven $(2,2 \%)$ wijkt maar weinig af van de totale banenvernietiging $(2,6 \%)$. Hetzelfde geldt voor de totale winst aan werkgelegenheid en de schepping van banen. Dit betekent dat het weinig voorkomt dat in bedrijven gelijktijdig banen worden geschapen èn vernietigd. Uit deze tabel blijkt ook dat de arbeidsmobiliteit een stuk hoger ligt dan het tempo waarin banen worden geschapen of vernietigd. In de onderzochte periode 1988-1990 ging het bij circa tweederde van de uitstroom om vrijwillig vertrek. Met het verslechteren van de conjunctuur is het aandeel van vrijwillig vertrek overigens gedaald tot circa 50 procent in 1994.

Van de banen die in 1994 door uitstroom vrij kwamen, werd een derde deel intern en een derde deel extern opgevuld, terwijl het resterende deel kwam te vervallen ${ }^{37}$. De interne mobiliteit lag in 1994 gemiddeld op 3,1 procent van het personeelsbestand. In bedrijven met een hoge gemiddelde leeftijd van de werknemers lag die interne mobiliteit overigens beduidend lager. De helft van de externe instroom in dat jaar kwam van een andere baan, een vijfde kwam van school, een vijfde was werkloos en het resterende gedeelte participeerde voordien niet op de arbeidsmarkt. Factoren die van invloed zijn op de mobiliteit van werknemers, zijn het opleidingsniveau van de werknemer en het technologisch gehalte van het bedrijf. Niet alleen is de baanmobiliteit groter in sterk geautomatiseerde bedrijven, ook blijkt de informatisering een positieve invloed te hebben op de opwaartse baanmobiliteit. Het blijkt dat personen in sterker geïnformatiseerde segmenten een zeer sterke positie hebben op de arbeidsmarkt. In lijn hiermee wordt ook gevonden dat personen die in die beroepssegmenten werkzaam zijn, een relatief gering risico kennen om werkloos te worden ${ }^{38}$.

Er is dus een grote mate van arbeidsmobiliteit op de Nederlandse arbeidsmarkt en het opleidingsniveau speelt hierbij een rol. Zal nu als gevolg van de gestegen onderwijsparticipatie ook de baanmobiliteit toenemen? De gegevens die ter beschikking staan over baanveranderingen beslaan nog een te korte periode om hierover enig uitsluitsel te kunnen geven. Wel blijkt dat de baanmobiliteit zeer conjunctuurgevoelig is ${ }^{39}$. Er kan echter aangevoerd worden dat onderwijs bijdraagt aan het adaptieve vermogen van werknemers. Het is ook een van de doelstellingen van het onderwijs om naast het overbrengen van kennis het zelflerend vermogen te ontwikkelen.

37] W.C.M. Praat, H.R.M. Smulders en J.M. van Werkhooven, Trendropport vroog noor orbeid 1996; OSA-rapport nr. 22 , 's Gravenhage, 1996.

38] P.M. de Graaf. E.J.C. Josten, P.T. van den Berg en R. Luijkx, 'Informatietechnologie en kansen op de arbeidsmarkt'; Tijdschrift voor Arbeidsvroagstukken, 1995, jrg. I1, nr. I, blz. 7-20.

39] R. Kunnen e.a., Trendropport oonbod von orbeid 1995; OSA-rapport nr. 21, 's-Gravenhage, 1995. 
In de bespreking van de toekomstige ontwikkelingen op de verdelingsdimensie 'beroep' is de belangrijkste vraag wat er zal gebeuren met de huidige discrepantie tussen de omvang van de werkgelegenheid en de aanspraken op werk? Om maatschappelijke ontwrichting tegen te gaan, is het immers van groot belang die kloof te dichten.

De voorlopige conclusie die op dit punt uit het voorgaande kan worden getrokken, is dat de Nederlandse samenleving het dieptepunt inmiddels achter zich heeft gelaten. De kloof tussen werkgelegenheid en arbeidsaanbod zal in de periode tot 2015 niet alleen kleiner worden, maar zelfs in 'gunstige' zin omslaan. Aanvankelijk zal dit waarschijnlijk nog niet zo'n vaart lopen; tot 2000 zal er weinig veranderen in het werkloosheidsniveau - dit natuurlijk afhankelijk van het niveau van de economische groei. Daarna, en vooral in de tien jaar tussen 2005 en 2015, kan de positieve ontwikkeling zich doorzetten en uiteindelijk zelfs tot arbeidsmarktkrapte leiden. De achtergrond van deze ontwikkeling betreft eerst en vooral een gelukkig samengaan van structurele factoren, dat wil zeggen factoren die niet of slechts in beperkte mate door regeringsbeleid zijn te beïnvloeden. Het gaat hier om achtereenvolgens de internationale economische situatie en de werkgelegenheidsgroei die daarvan in Nederland het resultaat is, de sociaal-culturele ontwikkeling van een geleidelijk groeiend arbeidsaanbod, inclusief de normalisering van deeltijdwerk, en de demografische ontwikkeling van de potentiële beroepsbevolking.

Maar deze positieve structurele ontwikkelingen zijn niet toereikend om de problemen aan de onderkant van de arbeidsmarkt volledig op te lossen. De hierboven uitgevoerde analyses laten zien dat er, afgezien van een zekere mate van 'ontdringing' die het gevolg zal zijn van een grotere arbeidsvraag in de hogere regionen, aan de onderkant van de arbeidsmarkt minder vraag wordt gegenereerd dan het arbeidsaanbod zou behoeven om toegang te krijgen.

Dit betekent dat de structurele ontwikkelingen door gericht beleid moeten worden ondersteund en gefaciliteerd. De Raad denkt hierbij in de eerste plaats aan de verruiming van de arbeidsvraag voor lager opgeleiden. Tal van maatschappelijk nuttige activiteiten in de sectoren van zorg en dienstverlening worden thans niet vervuld, terwijl in de komende twee decennia, als gevolg van veroudering en vergrijzing, de niet officieel op de arbeidsmarkt geregistreerde vraag hiernaar juist zal toenemen. Alles moet in het werk worden gesteld om een belangrijk deel van deze zorgtaken te 'formaliseren'. Dit kan alleen dan 'marktconform' geschieden als het stelsel van sociale zekerheid inclusief het minimumloon daarop wordt toegesneden. Het blijft van het grootste belang dat manieren worden gevonden, waardoor de sociale zekerheid 'employability' ondersteunt zonder het niveau van de zekerheid uit te hollen (vgl. hfdst. 4). De wijze waarop het stelsel van sociale zekerheid thans interfereert met mogelijkheden de op de arbeidsmarkt te verdelen werkgelegenheid te verruimen, heeft vooral aan de onderkant van de arbeidsmarkt negatieve effecten. In de tweede plaats kan direct worden aangehaakt bij de vraagkant van de arbeidsmarkt door de groei en ontwikkeling van ondernemerschap te stimuleren, bijvoorbeeld door verdere fiscale stimulansen te geven aan bedrijfsinvesteringen, bij voorkeur gericht op sectoren die tegemoet komen aan zowel de groeiende vraag naar zorg als aan het omvangrijke aanbod van laaggeschoolden.

Op basis van bovenstaande overwegingen en exercities acht de Raad het in ieder geval onverstandig om de kloof tussen werkgelegenheid en arbeidsaanbod aan de kant van het arbeidsaanbod te gaan dichten. Wie, gelegitimeerd door welke ideologie dan ook, mensen ervan wil overtuigen dat werk niet zo 
belangrijk is en dat er maatschappelijk moet worden afgerekend met de fixatie op werk, productiviteit en economische groei, bevordert een situatie die al vroeg in de eenentwintigste eeuw aanleiding kan geven tot grote maatschappelijke spanningen. Gelukkig is de behoefte aan individuele verantwoordelijkheid, aan zinvolle activiteit en autonomie de laatste decennia even sterk gegroeid als de nieuwe mogelijkheden die arbeid voor mens en samenleving biedt. Misschien is het zelfs wel zo dat voor steeds meer mensen de geëmancipeerde vormen van (betaalde) arbeid juist dichter bij het utopische beeld van de jaren zeventig zijn komen te staan. Voor hen is het verschil tussen de utopie van de jaren zeventig en de groeiende realiteit van de jaren negentig geleidelijk aan het verdwijnen. De arbeidsmarkt heeft daar in de nabije toekomst slechts profijt van.

\subsection{Onderwijs en opleiding}

\subsection{Inleiding}

Onderwijs behoort tot de belangrijkste schaarse maatschappelijke goederen. De richting en het soort onderwijs en de mate waarin iemand dat onderwijs heeft genoten, bieden een goede indicatie over zijn of haar plaats op de maatschappelijke ladder en over de relatieve voordelen die daarmee gepaard gaan. Of men ongelijkheid nu bestudeert aan de hand van voor een individu weinig beïnvloedbare uitkomsten van de arbeidsmarkt als inkomen of werkloosheid, vrijwillige gedragskeuzen als het patroon van deelname aan vrijetijdsactiviteiten of opvattingen over moraliteit en politiek, dan wel het patroon van sociale contacten en netwerken dat men onderhoudt, steeds blijkt het contrast tussen hoger en lager opgeleiden een belangrijke, zo niet overheersende vorm van segmentatie in onze samenleving te zijn. Maatschappelijke verdelingsprocessen van uiteenlopende aard blijken voor hoger opgeleiden in veel gevallen gunstiger te verlopen dan voor lager opgeleiden. Ook wanneer het niet gaat om de verdeling van schaarse goederen, maar om differentiaties van niet-economische aard, is er telkens een groot onderscheid tussen hoger en lager opgeleiden 40 .

Onderwijs biedt dus een toegangsbewijs voor een goede maatschappelijke positie. Dit toegangsbewijs heeft in de afgelopen decennia aan belang gewonnen, hetgeen niet verwonderlijk is als men bedenkt dat maatschappij en economie kennisintensiever en complexer zijn geworden. Hierdoor hebben meer traditionele entreebewijzen zoals sociale herkomst of ervaring, aan belang en effectiviteit ingeboet. Zeker in een cultuur die gelijke kansen hoog in het vaandel heeft staan, is onderwijs bij uitstek het instrument waarmee die gelijke kansen moeten worden gerealiseerd. Maar daarmee zijn de traditionele onderscheidingscriteria natuurlijk nog niet uit het zicht verdwenen.

De betekenis van sociale herkomst als factor in maatschappelijke allocatie verloopt nu minder direct en wordt in toenemende mate gemedieerd door het onderwijs. Ook de discussie over gelijkheid en gelijke kansen is verplaatst naar de toegankelijkheid van de onderwijsmarkt. Anders gezegd, de vraag werd actueel of kinderen uit de 'betere' sociale milieus niet ook een betere kans hebben op toegang tot de interessantere onderwijssoorten, en of aan deze vorm van ongelijkheid niet iets zou moeten worden gedaan. Sinds het midden van de jaren zestig is de discussie over het onderwijs vooral door deze vraag geïnspireerd. Er moest voor worden gezorgd dat talent uit alle lagen van de bevolking werd gerecruteerd, niet alleen uit de hogere. Het 'talentenproject' van Van Heek ${ }^{41}$ werd in de loop van de jaren zestig dan ook de start van een

40] Aldus Harry B.G. Ganzeboom, 'Onderwijsexpansie en onderwijskansen'; in: Ganzeboom en Ultee (red.), op. cit.

41] F. van Heek e.a., Het verborgen talent: Milieu, schoolkeuze en schoolgeschiktheid; Amsterdam, Noord-Hollandsche Uitgeversmaatschappij, 1968. 
belangrijke traditie in de Nederlandse sociologie van onderwijs en sociale stratificatie. Ook in de politiek heeft deze vraagstelling tot tal van acties geleid, al of niet geënt op de resultaten van wetenschappelijk onderzoek. Vele beleidsmaatregelen op onderwijsterrein hadden (en hebben) als achterliggende doelstelling het optimaliseren van de toegankelijkheid van het onderwijs. Saillant zijn in dit verband de doorstroomregelingen die met de Mammoetwet van 1962 werden doorgevoerd, het compensatie-onderwijs van de jaren zeventig en de wet op de studiefinanciering van de jaren tachtig.

Het optimisme over de effectiviteit van dergelijke maatregelen is inmiddels danig bekoeld. Dat het onderwijs als vehikel voor maatschappijhervorming dienst kan doen, mag voor de langere termijn dan waar zijn, voor de korte termijn bleek ook het onderwijs niet gemakkelijk los te wrikken uit zijn maatschappelijke context. Sociale en culturele arrangementen bleven niet alleen een aselecte toegang tot het onderwijs in de weg staan, ook werd duidelijk dat ze een grote invloed bleven houden op de slaagkans van degenen die tot de desbetreffende onderwijssoort waren toegelaten. Ook viel niet weg te poetsen dat cognitieve en intellectuele vermogens ongelijk over de bevolking zijn verdeeld. Hoe die drie verschillende zaken uit elkaar gehouden moesten worden en welke van die drie nu wel of niet onder de noemer van gelijke kansen, laat staan sociale gelijkheid, moesten worden geschaard, werd een politiek issue van de eerste orde ${ }^{42}$. Het gaat niet te ver om nu - in retrospect - te constateren dat het probleem niet steeds adequaat is opgelost.

\subsubsection{Aard en betekenis}

Onderwijs en opleiding zijn in de loop van de tijd dus een steeds belangrijker allocatiemechanisme geworden. Hoe hoger de opleiding, des te groter ook het aandeel in andere schaarse maatschappelijke goederen, zoals inkomen, beroep of huisvesting. Er bestaan twee groepen van verklaringen voor de geprivilegeerde positie van hoger opgeleiden. Deze beide typen van verklaringen sluiten elkaar overigens niet uit.

De technisch-functionele verklaring ziet de geprivilegeerde positie als de beloning van een inspanning; een inspanning die bestaat zowel in het volgen van een studie als in het afzien van inkomen. Inkomensverschillen die uiteindelijk uit opleiding voortkomen, zijn in die opvatting tegelijkertijd de economische prikkels die ervoor zorgen dat de juiste mens op de juiste plaats komt. Dit soort verklaringen stuit echter op verschillende problemen. Er wordt op gewezen dat de relatie tussen de vraag naar geschoolde arbeid en de expansie van het onderwijs niet duidelijk is, en dat ook de relatie tussen scholing en productiviteit omstreden is. Ook maakt de technisch-functionele theorie niet duidelijk waarom de gevolgde opleiding ook onderscheidend werkt op levensgebieden die niets met de op school geleerde vaardigheden van doen hebben.

Een andere groep van verklaringen haakt daarom aan bij culturele distincties tussen opleidingsgroepen en ziet de hoger opgeleiden eerder als een traditionele stand, die steeds probeert zich van anderen af te scheiden en de eigen maatschappelijke machtspositie te behouden. Verschillen in talent en in cognitieve vermogens zijn in deze opvatting niet meer dan het beginpunt van een verdeling van opleidingsgroepen. Ook andere elementen, zoals kenmerkende gedragspatronen, netwerken, familie en werk, bevorderen de selectieve of onderscheidende kracht van het opleidingscriterium. Deze beide typen verklaringen sluiten elkaar overigens niet uit.

42] Van Kemenade onderkende reeds in 1970 dat de geleidelijke vervanging van het sociale herkomst-criterium door het onderwijscriterium niets afdoet aan het bestaan van sociale ongelijkheid als hij vaststelt 'dat het streven naar gelijke kansen op deze wijze in feite neerkomt op het streven naar sociale ongelijkheid op grond van cognitieve en technische bekwaamheden en prestaties in plaats van afkomst'. Zie J.A. van Kemenade, 'Onderwijs en Sociale Ongelijkheid'; Sociologische Gids 17-6, 1970, blz. 479. 
De vergrote maatschappelijke betekenis van onderwijs concentreert zich vooral op de wereld van beroep, arbeidsmarkt en economische productie. Dit lijkt een gemeenplaats, maar is het niet. Nog niet zo lang geleden werden belangrijke delen van het onderwijs toegesneden op bevolkingscategorieën die naar verwachting buiten de formele arbeidsmarkt zouden blijven. De 'huishoudschool' was hiervan een voorbeeld, maar ook de mms - middelbare meisjesschool - gold als een prima opleiding voor diegenen die zich buiten de arbeidsmarkt - in huwelijk en gezin - op redelijk niveau moesten zien te handhaven. Bovendien gold toen duidelijker dan thans dat het onderscheid tussen opleidingen die zich expliciet op algemene vorming richtten en opleidingen die in een meer utilitaristische context waren ingebed, tegelijkertijd ook morele connotaties had. Daarin lag bijvoorbeeld het verschil tussen de 'klassieke' opleiding van het gymnasium en het wereldser en praktischer onderwijs van ulo en hbs.

Hoewel er zeker nog resten van dergelijk denken traceerbaar zijn, is de traditionele institutionele scheiding tussen algemene vorming en beroepsopleiding geleidelijk verrafeld. Hoewel het op zichzelf beter past bij de ontwikkeling van een kennisintensieve samenleving, probleemloos is dat proces niet verlopen. Het lijkt er wel eens op dat met de erosie van de institutionele scheiding ook het op zichzelf belangrijke onderscheid tussen beide onderwijsaspecten onder druk kwam te staan. Gevolg was weer dat alleen dat onderwijs als relevant werd beschouwd dat in directe zin voorbereidt op beroepsuitoefening. Vrijwel elke onderwijsinstelling wordt ook thans nog geconfronteerd met de door ouders, leerlingen en studenten gesteunde gedachte dat de oriëntatie op een beroep niet snel genoeg kan plaatsvinden. In een (te) ruime arbeidsmarkt is het immers de kunst om je plaats zo vroeg mogelijk veilig te stellen; wanneer te veel tijd met algemene vorming zou worden verdaan, dan zouden de beroepskansen navenant kleiner worden - althans, dat is de gedachte. Het heeft ertoe geleid dat zowel het algemeen vormend onderwijs als het beroepsonderwijs aan eigenheid inboette, dat kinderen die daar nog lang niet aan toe waren zich op een beroep of studierichting moesten vastleggen en dat van overscholing en diploma-inflatie werd gesproken, zodra er voor die specifiek opgeleiden niet even specifieke banen voorhanden waren. Voorzover onderwijsinstellingen zich meenden aan te passen aan de arbeidsmarkt, hanteerden ze daarvan een erg mechanisch en traditioneel beeld. Immers, terwijl de afbakenbaarheid en specificiteit van beroepen onder invloed van de 'post-industrialisering' afnam en er in de dienstverlening vele functies ontstonden, die wel algemene vorming, maar weinig specifieke beroepsvoorbereiding vereisten, groeide de specificiteit van de in het onderwijs aangeboden opleidingen zienderogen. Het duidelijkst manifesteerde dit zich in het hoger onderwijs, waar zowel in hbo als wo het aantal studierichtingen opliep tot boven de driehonderd ${ }^{43}$.

De 'studierichting' of 'opleiding' is bovendien in de jaren tachtig steeds smaller geworden, omdat vanwege bezuinigingen de bijvakken uit de curricula verdwenen. Ook op het voortgezet onderwijs heeft dit effect gehad. De 'pakketten' of 'profielen' die in die fase van algemeen vormend onderwijs door leerlingen moeten worden gekozen, kwamen steeds meer in het licht van de latere beroepskeuze te staan. Dat van een serieuze beroepskeuze op die leeftijd leerlingen zijn dan 15, 16 jaar - nog nauwelijks sprake kan zijn, wordt weliswaar algemeen erkend, maar in de praktijk wordt aan die erkenning weinig gevolg gegeven. De fricties die zich tussen onderwijs en arbeidsmarkt voordoen - overscholing, diploma-inflatie en slechte aansluiting van tal van studierichtingen op de arbeidsmarkt - zijn daarvan het gevolg. Het is niet verwonderlijk dat die slechte aansluiting op de arbeidsmarkt vooral de arbeidsmarkt van de hoger opgeleiden betreft. Voor hen geldt immers, meer

43] Zie: WRR, Hoger Onderwijs in Fasen; Rapporten aan de Regering nr. 47, 's-Gravenhage, Sdu Uitgeverij, 1995. 
dan voor bijvoorbeeld het mbo-niveau, dat de specificiteit van hun functies niet alleen is afgenomen, maar ook aan snelle verandering onderhevig is.

Voor deze toekomstverkenning is het van belang te onderzoeken hoe de betekenis van onderwijs voor beroep en arbeidsmarkt zich zal gaan ontwikkelen. Cruciaal hierbij is de vraag of de betekenis van diploma's in de nabije toekomst gehandhaafd blijft of dat hierin verandering zal optreden. Het antwoord op deze vraag heeft alles te maken met de ontwikkeling van de werkgelegenheid, waarop in de vorige paragraaf is ingegaan. Bij een ruime arbeidsmarkt ligt het voor de hand dat verdringingsverschijnselen zich zullen blijven voordoen en dat bijgevolg van diploma-inflatie sprake zal blijven. Dit wordt nog eens bevorderd door de omstandigheid dat meer jongeren dan gedwongen worden om, ter vermijding van werkloosheid, door te studeren voor hogere diploma's. Hoe krapper echter de arbeidsmarkt, des te groter is de kans dat ook de hoger opgeleiden weer op hun eigen niveau worden 'geruimd', en des te geringer de kans op verdringing en diploma-inflatie.

De Graaf heeft het verschijnsel diploma-inflatie voor de afgelopen 20 jaar onderzocht ${ }^{44}$. Hij conludeert dat in deze periode de betekenis van het onderwijs voor het beroepsniveau inderdaad is afgenomen. Hij baseert zijn conclusie op de volgende bevindingen:

- Tussen 1971 en 1991 is voor elk opleidingsniveau het gemiddelde functieniveau gedaald. Mensen zijn steeds meer onder hun niveau gaan werken; er is zich zoiets als 'onderbenutting' en 'overscholing' gaan manifesteren.

- De toegevoegde waarde van lagere diploma's is afgenomen ${ }^{45}$. De relatieve waarde van het wo- en hbo-diploma is toegenomen tussen 1971 en 1985, maar is nadien weer enigszins gedaald. De marginale opbrengst van deze diploma's is steeds relatief hoog geweest in de onderzochte periode, ongeacht het feit dat de absolute waarde is gedaald.

- Er heeft verdringing plaats gevonden. Hoger opgeleiden hebben lager opgeleiden naar banen met een lager functieniveau gedrukt. Dit heeft zich vooral voorgedaan onder nieuwkomers op de arbeidsmarkt, met name jongeren en vrouwen.

Zoals hierboven al werd aangestipt, behoeft deze conclusie een paar kanttekeningen. Allereerst is er een technische nuancering. Er bestaat namelijk een samenhang tussen sociale herkomst, opleidingsniveau en beroepsstatus. Eerder is opgemerkt dat in de loop van de tijd de sociale herkomst minder bepalend is geworden voor het bereikte onderwijsniveau. Met andere woorden: of een kind verder gaat leren of niet, is minder afhankelijk geworden van de sociale positie van zijn ouders. Uit onderzoek is echter ook gebleken dat de directe invloed van de sociale herkomst op de bereikte beroepsstatus sterk is afgenomen. Vroeger was het beroepsniveau dat iemand bereikte, veel sterker afhankelijk van de sociale positie van zijn ouders ${ }^{46}$. De relatieve waardevermindering van diploma's is dus voor een deel schijn: de gediplomeerden kregen vroeger die betere baan ók omdat hun ouders nu eenmaal een hoge sociale status hadden. Dit betekent dat de conclusie van diploma-inflatie moet worden gerelativeerd. Maar dit is inderdaad niet meer dan een relativering: het belang van het behaalde diploma wordt er immers niet groter door en de dalende trend blijft, ook als we met deze technische nuancering rekening houden, wel degelijk waarneembaar ${ }^{47}$.

${ }^{44}$ ] Paul M. de Graaf, 'Onderwijs en arbeidsmarkt; ontwikkelingen in de waarde van diploma's'; in: Ganzeboom en Ultee (red.), op. cit.

45] Voor de operationalisering van dit begrip, zie De Graaf, op. cit. Ruwweg komt dit begrip neer op het bereikte functieniveau in de arbeid, vergeleken met het naastlagere opleidingsniveau.

46] Zie P.M. de Graaf en R. Luijkx, 'Van 'ascription' naar 'achievement'? Trends in statusverwerving tussen 1930 en 1980'; Mens en Moatschappij, vol. 67, 1991, blz. 412-433.

47] De Graaf, op. cit., met name de figuren $5.3,5.4$ en 5.5 . 
Een tweede kanttekening werd ook al eerder aangestipt en vormt een belangrijk element van het WRR-rapport Hoger onderwijs in fasen ${ }^{48}$. Op twee manieren werd daar aangegeven dat uit de constatering van overscholing niet mag worden afgeleid dat de scholingsinspanning in Nederland te groot zou zijn. Zo blijkt allereerst dat het rendement van onderwijsinvesteringen voor individu en samenleving èn positief èn stabiel is. Ook blijkt er onvoldoende aandacht te bestaan voor de positieve effecten van verdringing, bijvoorbeeld op de internationale concurrentiepositie. De hogere opleidingsniveaus kunnen de desbetreffende functies immers ook een dynamiek bezorgen, die ze tevoren niet hadden. Daarnaast wordt in datzelfde rapport aangegeven, dat het eerder de specificiteit van de scholingsrichting is dan het algemene scholingsniveau dat voor fricties met de arbeidsmarkt zorgt. De (steeds populairder wordende) gedachte dat de scholingsinspanning zelf te groot zou zijn, komt voort uit een ongelukkige contaminatie van specifieke scholingsrichting en algemeen scholingsniveau. In het licht van de arbeidsmarktvooruitzichten voor de komende twee decennia (zie par. 2.2.2) blijkt hoe kortzichtig ze is. Het is daarom maar goed dat de onderwijsexpansie zich tamelijk autonoom zal blijven voortzetten, ook al weet de arbeidsmarkt op dit moment weinig raad met de huidige specificiteit van zoveel opleidingen.

Voor de werkgever blijkt vooral de relatieve positie van het onderwijsniveau van de werknemer van belang te zijn. Hij zal in beginsel de hoogst geschoolde kiezen, niet omdat diens specifieke kwalificaties voor de functie vereist zijn, maar omdat hij verwacht dat die werknemer, door het behalen van zijn of haar kwalificatie, heeft bewezen een algemene bekwaamheid te bezitten (in termen van intelligentie, vlijt, doorzettingsvermogen) ${ }^{49}$. Op deze wijze loont het voor de werknemer om meer onderwijs te volgen, ook in een (te) ruime arbeidsmarkt. Het marginale nut is aanwezig en daarmee de incentive. Men kan het ook negatief formuleren. Niemand kan het zich permitteren niet mee te doen aan het algemene proces van opstuwing van het onderwijsniveau. De Graaf spreekt in dit verband van een prisoner's dilemma ${ }^{50}$.

Maar natuurlijk laat dit alles onverlet dat maatregelen genomen zouden moeten worden om de fricties tussen opleiding en arbeidsmarkt glad te strijken. Een van de belangrijke elementen in een dergelijke strategie is te erkennen dat aspecten van algemene vorming een belangrijker plaats moeten innemen in het initiële onderwijs, en dat juist door algemene vorming, en de kwaliteiten die daaruit voortkomen, te accentueren, de relatie met de arbeidsmarkt kan worden verstevigd. Dit is een fundamentele wijziging ten opzichte van de geleidelijk binnengeslopen notie dat algemene vorming 'luxe' is en beroepsopleiding 'noodzaak' 51 .

Hoe zal nu in de periode tot 2015 de wederzijdse aanpassing van scholingsniveau en beroepsfunctieniveau zich ontwikkelen? Eerder is aangegeven dat rekening moet worden gehouden met een veel pluriformer arbeidsmarkt, waarbij naast voortgaande flexibilisering ook processen van polarisatie en regradatie kunnen optreden. De groep van laagopgeleiden zou ernstig benadeeld worden als dergelijke ontwikkelingen tenderen naar een gepolariseerde arbeidsmarkt. Deze werkt weliswaar bevredigend voor gediplomeerden op woen hbo-niveau, maar drukt het geheel van middenopleidingen naar de lagere functieniveaus. Als er te weinig arbeidsplaatsen zijn, zullen deze processen

48] WRR (1995), op. cit., speciaal par. 3.3.2.

49] Deze conclusie is conform de 'social screening'-theorie van Arrow. Zie K. Arrow, 'Higher education as a filter'; Journal of Public Economics, vol. 2, 1973, blz. 193-216.

so] De Graaf, op. cit., fig. 5.5 .

5'] Vgl. WRR (1995), op. cit. Overigens: over de mate waarin een dergelijke aanpassing van de inhoud van het onderwijs ook extra dynamiek genereert en in het verlengde daarvan extra werkgelegenheid, valt alleen maar te speculeren. 
zich voltrekken ten koste van de laagstopgeleiden, die zich dan geen plaats meer verwerven. Alleen een aanzienlijke regradatie van de arbeidsmarkt zal dan tot een goede wederzijdse aanpassing van scholingsniveau en beroepsfunctieniveau kunnen leiden. Dit veronderstelt dat de economie zich gunstig ontwikkelt, met een forse groei van de werkgelegenheid en een verregaande specialisatie in hoogwaardige productie en dienstverlening. Hoewel een dergelijk perspectief niet denkbeeldig is ${ }^{52}$, bestaat er alle reden - en dit niet alleen voor het heden - ook alternatieve manieren van werkgelegenheidsverruiming te beproeven. Het is immers onwaarschijnlijk dat het proces van 'ontdringing' zo'n vaart gaat lopen, dat op korte termijn voldoende soelaas voor lager geschoolden kan worden geboden. Evenzeer is het onwaarschijnlijk want niet in overeenstemming met de verdeling van talenten - dat het verschijnsel van lage scholing in voldoende mate kan worden uitgebannen. Een alternatieve manier die per saldo hetzelfde effect heeft, bestaat erin om juist aan de onderkant van de arbeidsmarkt het aantal posities voor laag- of minder geschoolden te doen uitbreiden. Zeker met het oog op de vergrijzing en de zorgbehoefte die hiervan het gevolg is (de thuiszorg!), zou een omzetting van sociale uitkeringen naar (minimum)lonen in de gezondheidszorg en andere vormen van elementaire dienstverlening soelaas kunnen bieden ${ }^{53}$.

De conclusie moet luiden dat de hier en daar gehoorde suggesties over het afnemend belang van onderwijs als toegangsbewijs voor een goede maatschappelijke positie met een korrel zout moeten worden genomen ${ }^{54}$. De onderstroom is er wel degelijk een van toenemend maatschappelijk belang van onderwijs en opleiding. Dit zal ook tot 2015 zo blijven, zeker als de ontwikkeling van de werkgelegenheid opnieuw tot het volgen van onderwijs uitnodigt. Dat niettemin vorm en inhoud van de scholingsinspanning niet helemaal meer passen bij de veranderde maatschappelijke omstandigheden is evenzeer waar. Dit vergt veranderingen in inhoud en inrichting van het onderwijs, waaronder een sterker accent op 'vorming' als basis voor steeds wisselende beroepsopleidingen. Een gevarieerd en flexibel stelsel van kortdurende beroepsopleidingen hoort daar zeker bij. Dergelijke veranderingen zijn inmiddels op verschillende plaatsen ingezet. In ieder geval mag de constatering van overscholing en diploma-inflatie er niet toe leiden dat de scholingsinspanning in de periode tot 2015 wordt verminderd. Dan zou niet alleen de arbeidsmarkt, maar ook het belang van onderwijs voor de arbeidsmarkt dramatisch verkeerd worden 'gelezen'; tijdelijke fricties zouden dan ten onrechte voor een algemene ontwikkelingslijn worden gehouden.

Tot besluit van deze paragraaf nog een enkel woord over de wijze waarop het onderwijs zich inhoudelijk en organisatorisch aan de veranderende omstandigheden kan aanpassen. Centraal staat hierbij de groeiende aandacht voor vorming. Men zou zich natuurlijk de vraag kunnen stellen of de groeiende technologische complexiteit van de samenleving niet ook een sterke instrumentele oriëntatie van het onderwijs vergt. Feit is in ieder geval dat die oriëntatie is gaan overheersen. Grote delen van het onderwijs in ons land - en zeker geldt dit de verschillende vormen van hoger onderwijs - concentreren zich op de overdracht van geaccumuleerde kennisbestanden, terwijl de meer vormende' vragen naar de achtergrond zijn verschoven. Kwesties rond de positionering van kennis in een bredere maatschappelijke context, de vraag hoe in steeds wisselende omstandigheden kennis kan worden gegenereerd die op die omstandigheden is toegesneden, de opvoedende, morele, activerende en op de toekomst gerichte inzet van het onderwijs: zij hebben het geleidelijk moeten afleggen tegen een sterk op het hic et nunc gerichte, waardevrije en

52] Zie dit rapport, par. 2.2.

53] Zie dit rapport, par. 2.5.

54] Zie ook WRR (1995), op. cit., blz. 73 . 
technisch-instrumentele inzet. Ook in organisatorisch opzicht hebben overwegingen van efficiency het vormingsconcept onder grote druk geplaatst. Massaliteit en grootschaligheid hebben nu eenmaal weinig opvoedende waarde; desondanks was het beeld van de 'afnemende marginale meerkosten per student of leerling' in de jaren zeventig en tachtig nog zo overheersend bij politici en school- en universiteitsbestuurders dat het een belangrijke rol heeft gespeeld in de grote fusiebewegingen en in het handhaven van een te grote omvang van klassen. Maar geleidelijk gaat het beeld kantelen en groeit besef voor de noodzaak om massaliteit kleinschalig te organiseren, omdat anders de vormingscontext tekort zal blijven schieten en de resultaten van ook een geïntensiveerd onderwijsproces steeds teleurstellend zullen zijn 55 . De Raad verwacht dat deze kanteling zich in de komende twee decennia zal voortzetten en dat ook hierdoor de aansluitingsproblemen van onderwijs en arbeidsmarkt zullen afnemen.

\subsubsection{Toegankelijkheid}

Nederland heeft in de afgelopen periode een grote onderwijsexpansie gekend, bij de mannen en in nog sterkere mate bij de vrouwen. Volgde in 1958 net 10 procent van de 20 -jarige mannen en ruim 3 procent van de 25 -jarige mannen voltijdonderwijs, in 1991 waren die percentages opgelopen tot 43 respectievelijk bijna 10 procent. Bij de vrouwen waren de percentages in 1958 4,5 en minder dan 1 ; in 199136 en ruim $6{ }^{56}$. Ook voor wat het gemiddeld aantal genoten opleidingsjaren betreft, is er sprake van een duidelijke stijging die ook, zij het in enigszins afgevlakte zin, zal blijven voortgaan. Bij de mannen nam het gemiddeld aantal genoten jaren opleiding toe van 11 jaar voor het cohort 1950 tot 12,5 jaar voor het cohort 1970 (d.w.z. degenen die in 1995 de leeftijd van 25 jaar hebben bereikt). De verwachting is dat voor het cohort 1990 (degenen die in 2015 de leeftijd van 25 jaar bereiken) het gemiddelde op 13,4 jaar zal liggen. $\mathrm{Bij}$ de vrouwen is het beeld vergelijkbaar. In de loop der tijd is overigens wel een afvlakking van de toename waarneembaar (zie tabel 2.12).

Tabel 2.12 Aantal jaren opleiding per cohort (mannen)

\begin{tabular}{ll}
\hline Cohort & Aantal jaren opleiding \\
\hline 1950 & 11,0 \\
1960 & 11,8 \\
1970 & 12,5 \\
1980 & 13,0 \\
1990 & 13,4 \\
\hline
\end{tabular}

Bron: H. Ganzeboom, op.cit.

Ook als de onderwijsdeelname van de relevante leeftijdsgroepen vanaf 1980 in kaart wordt gebracht, blijkt uit figuur 2.6 opnieuw dat ook in deze recente periode een forse stijging heeft plaatsgevonden. De sterk verruimde en verlengde deelname aan het onderwijs heeft de traditionele waterscheidingen tussen onderwijssoorten voor een belangrijk deel doorbroken. Ook dit is expliciet voorwerp van onderwijsbeleid geweest om de toegankelijkheid van interessant onderwijs te vergroten voor alle lagen der bevolking ${ }^{57}$.

Intussen ziet de onderwijsmatrix van het CBS eruit als een waar labyrint, zoals blijkt uit onderstaande matrix voor het jaar 1994. In de onderwijsmatrix

55] Commissie van Eyndhoven, Groepsgrootte in het onderwijs; Tweede Kamer 1996/1997, 25065, 22 oktober 1996.

56] Zie Centraal Bureau voor de Statistiek, Vijfennegentig ja ar statistiek in tijdreeksen, 1899-1994; 's-Gravenhage, Sdu Uitgeverij.

57 Zie dit rapport, par. 2.3.1. 
Figuur 2.6 Ontwikkeling van de onderwijsparticipatie in regulier voltijdonderwijs voor enkele leeftijdsgroepen, $1978=100$

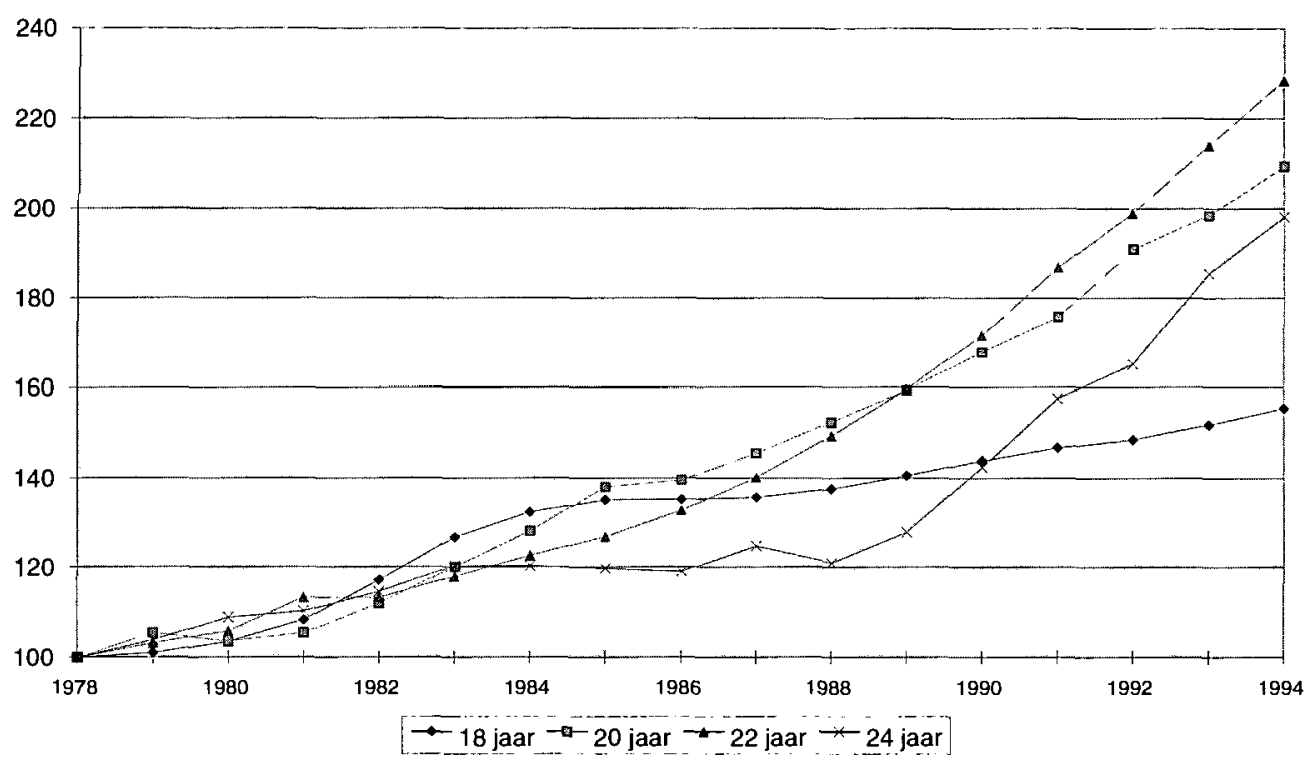

Bron: Eigen berekeningen WRR, op basis van Centraal Bureau voor de Statistiek.

staan de overgangen binnen het voltijdonderwijs over de periode van één jaar. De absolute aantallen leerlingen en studenten die in enig jaar een overstap maken binnen het onderwijs, worden sterk beïnvloed door de demografische ontwikkeling. Daarom zijn in de figuur de stromen weergegeven als percentages van de (theoretisch) relevante leeftijdsgroepen. Op deze wijze maakt de figuur minder tijdgebonden interpretaties mogelijk, zoals: 17 procent van de kinderen stroomt met een diploma van het lbo op zak door naar het mbo, 8 procent van de kinderen behaalt een universitair diploma, of 1 procent behaalt een hbo-diploma en gaat aansluitend doorstuderen in het wo. De figuur is gebaseerd op de situatie ten opzichte van een jaar eerder; leerlingen/studenten die er een jaar tussenuit gaan, worden in de figuur als verlaters van, en vervolgens als toetreders tot, het onderwijssysteem geteld. Met deze kanttekeningen geeft de figuur een beeld van de voornaamste stromen die zich in het onderwijs voordoen. 


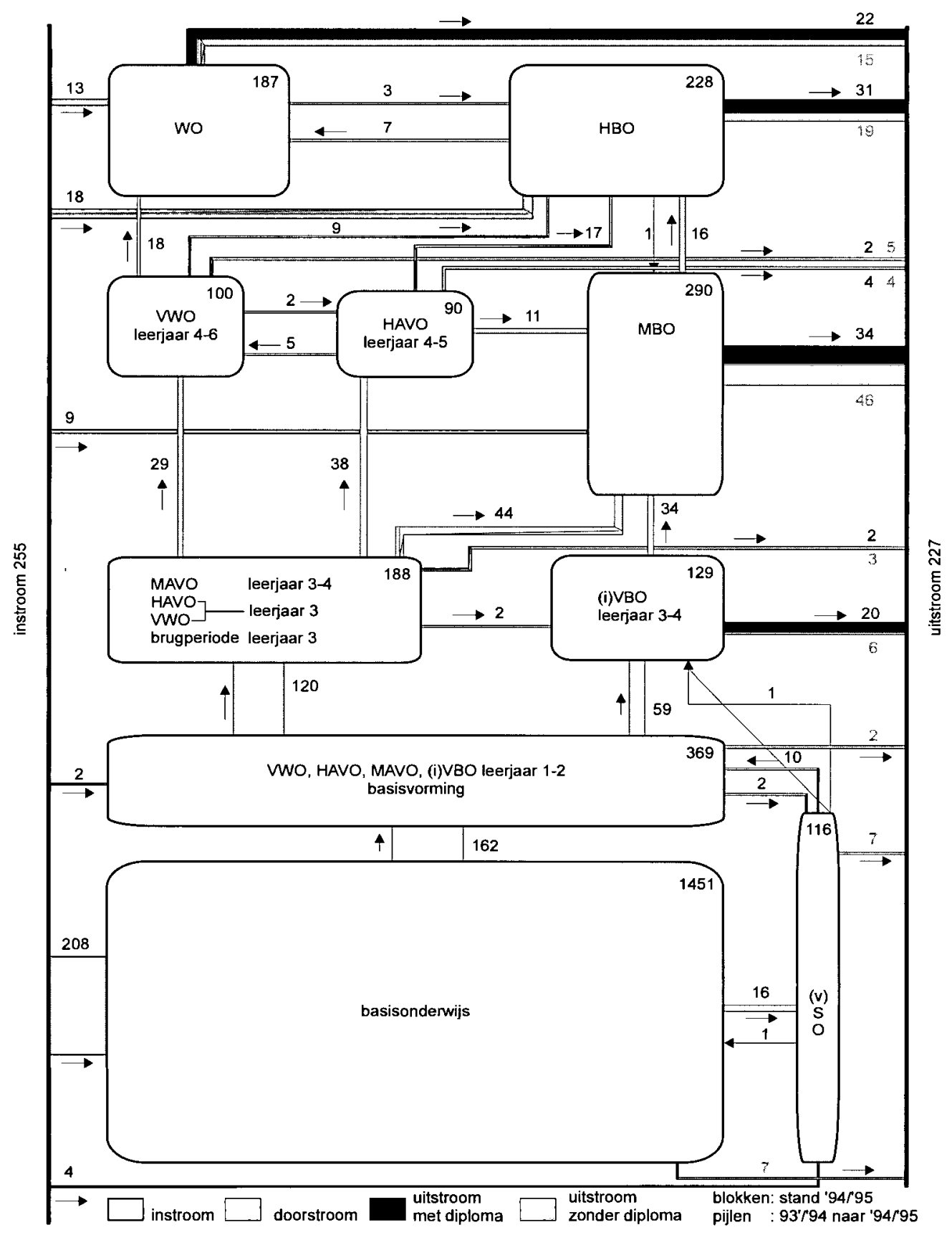

Bron: Centraal Bureau voor de Statistiek, Kwartaalschrift Onderwijsstatistieken 1996-II, 1996, blz. 49.

De cijfers die hierboven zijn verstrekt over de toename van het gemiddelde aantal onderwijsjaren per cohort, betreffen uitsluitend reguliere vormen van onderwijs, dat wil zeggen: onderwijs dat in de reguliere schooltypen wordt genoten en dat door de overheid wordt bekostigd. Andere soorten van onder- 
wijs, zoals korte en meer specifieke beroepsopleidingen, opleidingen voor een niet officieel erkend certificaat en dergelijke zijn niet meegeteld. In het totale onderwijspakket nemen deze soorten onderwijs niettemin een belangrijke plaats in. De omvang van deze bedrijfsopleidingen is aanzienlijk en bedroeg in Nederland in 1992, in geld gemeten, 7,2 miljard gulden. In datzelfde jaar nam ongeveer één op de drie werknemers in organisaties met meer dan vijf werknemers deel aan dergelijke opleidingsactiviteiten. De totale opleidingskosten bedroegen gemiddeld 2,1 procent van de loonsom. In de industrie, de openbare nutsbedrijven en de zakelijke dienstverlening lag dit percentage hoger, in de bouw, de handel, de horeca en de transport- en communicatiesector lager 58 . Tegelijkertijd wordt een trend waargenomen dat een steeds groter deel van de opleidingen op de werkplek plaatsvindt en dat leidinggevenden hierdoor meer opleidingstaken op zich nemen ${ }^{59}$. In het laatste decennium is het percentage van de loonkosten dat aan opleiding wordt besteed, licht gestegen ${ }^{60}$.

Over de voorlopige conclusie hoeft geen misverstand te bestaan: de deelname aan het onderwijs wordt groter en het aantal genoten opleidingsjaren eveneens. Er is weinig tot geen reden om aan te nemen dat deze toenemende toegankelijkheid zich niet tot 2015 zal voortzetten, zij het dat de cijfers erop wijzen dat de groei mogelijk enigszins zal afvlakken. Deze afvlakking zou overigens kunnen worden versterkt door de recente beperkingen in doorstroomkansen en studiefinanciering. Anderzijds valt het effect van de geleidelijk groeiende sector van bedrijfsopleidingen niet helemaal te voorspellen. De data met betrekking tot private en/of bedrijfsopleidingen kunnen immers maar moeilijk over langere perioden met elkaar worden vergeleken. Wel mag worden aangenomen dat de incidentie van korte en specifieke in company opleidingen zal toenemen en dat hierdoor zowel de ruimte als het accent op algemene vorming en algemene beroepsoriëntatie voor het reguliere onderwijs zullen toenemen.

\subsubsection{Scheefheid van de verdeling}

Over scheefheid kan in het verband van de onderwijsverdeling op twee manieren worden gesproken. Ten eerste is er de scheefheid in de onderwijsdeelname: de verdeling van de participatie over schoolniveaus. En ten tweede is er het aspect van de spreiding van de schooltypen en schoolniveaus zelf: de vraag of zich in de loop van de tijd veranderingen in de spreiding en breedte van het aanbod hebben voorgedaan.

Om met het laatste aspect te beginnen: in de structuur of opbouw van het reguliere onderwijsbestel is gedurende de naoorlogse periode weinig veranderd. De toename van het aantal deelnemers heeft het reguliere onderwijsgebouw zelf in ieder geval niet opgerekt: van grotere niveauverschillen tussen onderwijssoorten is - althans in Nederland - geen sprake, en ook zijn geen geheel nieuwe onderwijssoorten aan de top van de piramide geïntroduceerd. Integendeel: ondanks de steeds kennisintensievere accenten binnen de samenleving, is het plafond van het reguliere onderwijsgebouw even hoog gebleven. Niet alleen is de cursusduur van de universitaire studies korter geworden, ook is dankzij allerlei overheidsmaatregelen de studieduur dichter rinaire diensten en de maatschappelijke dienstverlening niet mee en komt daardoor op een lager bedrag dat aan bedrijfsopleidingen wordt besteed: niet 7,2 maar 3,5 miljard. 
bij de officiële cursusduur komen te liggen. De combinatie van deze twee ontwikkelingen heeft geleid tot 'samendrukking' van het onderwijsgebouw 6162 .

Indien de flexibilisering van het beroepsleven verder voortgaat (hetgeen in de verwachting ligt), kan het bijna niet anders of ook het onderwijsbestel zou zich daaraan (verder) moeten aanpassen. Hoe dit precies gebeurt, via een sterkere scheiding van publiek en privaat bekostigd onderwijs of via een nadere differentiatie en pluriformering van het publieke onderwijsbestel, valt op dit moment niet goed te voorzien. De voor de hand liggende neiging om het reguliere, door de overheid bekostigde voltijdonderwijs een platformfunctie te geven - dat wil zeggen: het zo in te richten dat het een basis vormt voor een veelheid van korte en specifieke beroepsopleidingen, waardoor het algemeen vormende en algemeen beroepsoriënterende karakter ervan wordt geaccentueerd - zou wel eens kunnen samenvallen met de normalisering van een bekostigingsverdeling. In die verdeling zouden de meer specifieke beroepsopleidingen hetzij in public-private partnerships, hetzij door de vragende instanties alleen (overheidsdiensten en bedrijven) bekostigd gaan worden. Voor het totale opleidingenpakket heeft dit hooguit als consequentie dat het gedifferentieerder en flexibeler zal worden.

Ten slotte is ook de spreiding in onderwijsniveau afgenomen. Aan de onderkant van de onderwijsverdeling is sprake van een voortdurende verlenging van de studieduur, waardoor steeds hogere eindniveaus worden gerealiseerd. Extrapolatie van deze gegevens laat zien dat ook in de komende decennia het percentage van de potentiële beroepsbevolking dat een hogere opleiding volgt, steeds groter wordt en dat daarmee de verhouding tussen lagere en hogere opleiding minder scheef en dus evenwichtiger wordt.

Tabel 2.13 Gerealiseerde en verwachte percentages onderwijseindniveau (mannen)

\begin{tabular}{llrrrrr}
\hline & & 1975 & 1985 & 1995 & 2005 & 2015 \\
\hline \multirow{3}{*}{ Laag } & & 41 & 39 & 34 & 32 & 28 \\
& lo & 19 & 16 & 12 & 10 & 7 \\
& Ibo & 17 & 18 & 17 & 16 & 15 \\
& mavo & 5 & 5 & 5 & 6 & 6 \\
& & 37 & 39 & 41 & 43 & 43 \\
\multirow{4}{*}{ Hoog } & 35 & 36 & 37 & 38 & 38 \\
& havo/mbo & 2 & 3 & 4 & 5 & 5 \\
& wwo & 21 & 22 & 24 & 26 & 28 \\
& & 14 & 14 & 15 & 16 & 17 \\
& hbo & 7 & 8 & 9 & 10 & 11 \\
\hline
\end{tabular}

Bron: H. Ganzeboom, op.cit.

Als deze trend zich ook na 1995 voortzet, mag men voor het jaar 2015 rekenen met geringere verschillen in opleidingsniveau dan nu het geval is. Clustert men de verschillende onderwijsniveaus in de categorieën 'laag' (bo/lbo/mavo), 'midden' (havo/mbo/vwo) en 'hoog' (hbo en wo), dan ontwikkelt zich de verhouding tussen die categorieën van een scheve verdeling (41:37:23) in 1975 naar een vrijwel 'normale' verdeling (28:43:28) in 2015. In termen van onderwijskansen gesproken, zou dit betekenen dat met de groei in het gemiddelde van de opleidingsverdeling, gecombineerd met een samengedrukte opleidingspiramide, geleidelijk een grotere gelijkheid wordt gerealiseerd: de

61] Vgl. Ganzeboom en Ultee, op. cit.

62] Een uitzondering hierop vormen de aio-opleidingen en later de onderzoekscholen, zij het dat hier een bestaande onderzoekpraktijk tot opleiding is geïnstitutionaliseerd. 
kans op een hoge of lage opleiding is dan gelijker geworden. De vraag is overigens wel of een dergelijke ontwikkeling voor een kennisintensieve samenleving onverdeeld gunstig is. Immers, een kennisintensieve samenleving vereist niet slechts dat meer mensen een hogere scholing krijgen, maar ook dat de top van de kennispiramide steeds verder naar boven wordt verlegd.

Een geheel andere vraag is of de trend dat opleidingsverschillen kleiner worden, er in de toekomst toe zal leiden dat de betekenis van onderwijs als bron van segmentatie zal afnemen. Als de onderwijsverschillen afnemen, ligt het zeker in eerste instantie voor de hand te veronderstellen dat hiermee ook de discriminerende betekenis van onderwijs afneemt. Daartegenover kan men aanvoeren dat in deze situatie niet zozeer absolute verschillen, maar relatieve verschillen doorslaggevend zijn. Als de verdeling samentrekt, zouden kleine verschillen belangrijker worden. Zo wordt wel geopperd dat in de loop der tijd de onderwijsrichting aan belang heeft gewonnen, zozeer zelfs dat de werkelijke hiërarchie in opleidingen niet wordt uitgedrukt door het niveau, maar vooral door de richting die men heeft gekozen. Ganzeboom stelt dat toetsing van deze bewering slechts een gedeeltelijke bevestiging oplevert ${ }^{63}$. Weliswaar beïnvloedt de richting de beroepsstatus die men via de opleiding verwerft, maar de invloed op het inkomen dat men met dat beroep verkrijgt, is beperkt. Voor deze toekomstverkenning wordt aangenomen dat deze ontwikkeling in de toekomst niet verandert. Daarnaast zou in dit verband de veronderstelling kunnen worden geopperd dat juist in een tijd van slechte arbeidsmarktkansen de niveauverschillen hoger worden opgespeeld dan op basis van objectieve feiten verwacht zou worden.

\subsubsection{Openheid en mobiliteit}

$\mathrm{Nu}$ blijkt dat de onderwijsverschillen als geheel zijn afgenomen en er geen reden is om te veronderstellen dat die trend in de toekomst wordt gekeerd, kan men zich de vraag stellen welke factoren de toegankelijkheid van en de doorstroming in de onderwijsverdeling bepalen èn in welke richting de ontwikkeling van toegankelijkheid en doorstroming zal gaan. Hierbij zijn uiteenlopende factoren in het geding. Veel aandacht is uitgegaan naar factoren zoals geslacht en sociaal milieu, en hun invloed op onderwijsniveau en onderwijsrichting. Voor wat het verleden betreft, is duidelijk sprake van een afnemende invloed van deze factoren. Deze trend zal zich doorzetten. Het duidelijkst spreekt dit voor de factor geslacht. Het is al eerder gememoreerd dat de deelname van vrouwen in hogere vormen van onderwijs enorm is toegenomen. Wel is aannemelijk dat vrouwen ook in de toekomst andere opleidingsrichtingen zullen blijven kiezen dan mannen 64 . In die zin kan men een onderscheid maken tussen 'vrouwelijke' en 'mannelijke' opleidingsrichtingen. In de afgelopen periode is er op dit punt geen sprake geweest van convergentie, integendeel: de keuzes zijn zelfs verder uiteen gaan lopen. Ook al studeren vrouwen nu even lang als mannen, de divergentie in richtingkeuzes zal nog geruime tijd een arbeidsmarktnadeel voor vrouwen opleveren. Alleen als de economische ontwikkeling juist die sectoren zou begunstigen waarvoor de vrouwelijke' richtingen opleiden, zou deze keuze positief kunnen uitwerken.

Traditioneel is in Nederland het sociaal milieu sterk bepalend geweest voor de opleiding die kinderen en adolescenten volgden 65 . Hoe lager de positie van de ouders in de sociale hiërarchie, des te kleiner de kans dat de kinderen verder gingen leren. Dit blijkt zeer duidelijk uit het niveau van de opleiding dat de oudere leeftijdscohorten hebben genoten. Figuur 2.8 laat zien dat het gedeelte

63] Zie Ganzeboom, op. cit.

64] Ibid.

65] Ibid. 
van de bevolking uit het cohort 1921-1930, dat gerekend naar beroep en opleiding van hun vader tot het laagste (eerste) kwartiel behoort, oververtegenwoordigd is bij de laagste onderwijseindniveaus. Omgekeerd is het hoogste (vierde) kwartiel oververtegenwoordigd bij de hoogste onderwijseindniveaus. Voor dit cohort bestonden min of meer gelijke onderwijskansen voorzover het behaalde onderwijseindniveau op mavo-niveau lag. Het eindniveau waarop alle kwartielen min of meer gelijke kansen hebben, is - door de toegenomen onderwijsparticipatie - voor het cohort 1961-1970 gestegen naar mbo-niveau. Dit blijkt uit figuur 2.9. Maar ook voor het cohort 1961-1970 is er nog een duidelijke invloed van de sociale herkomst op het behaalde eindniveau.

Figuur 2.8 Onderwijskans per herkomstkwartiel, cohort 1921.1930

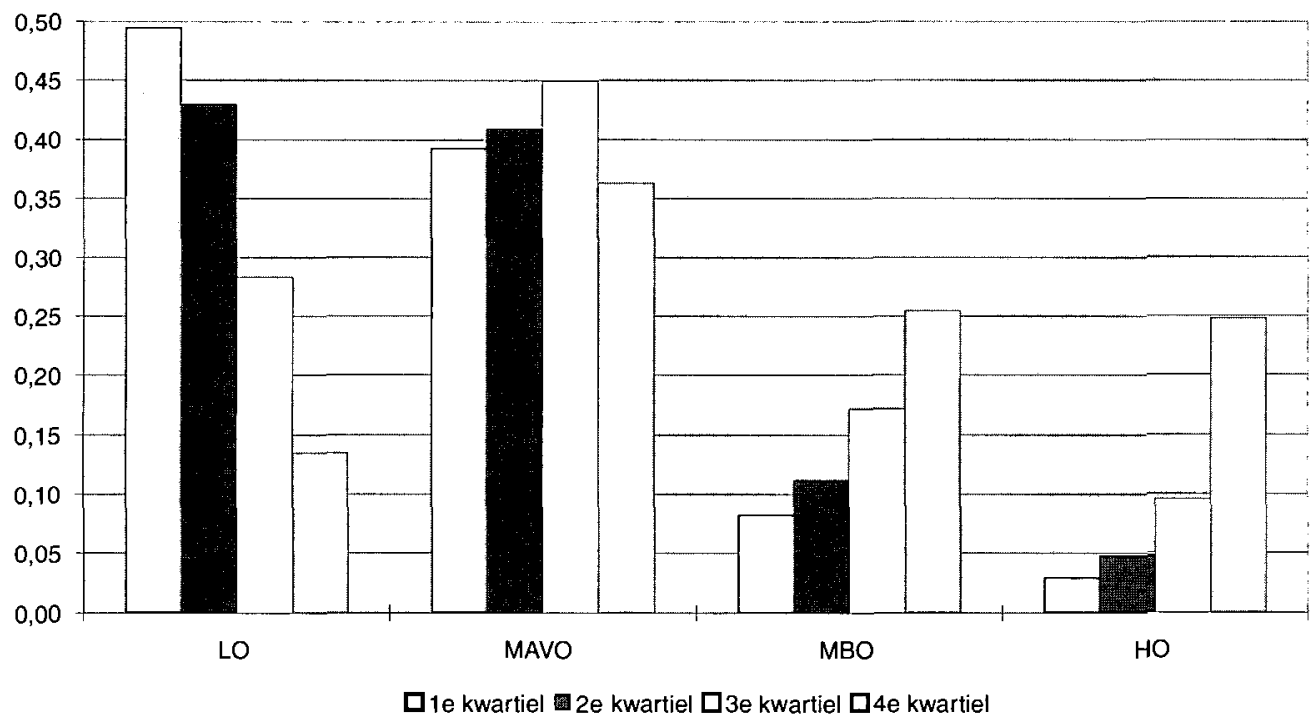

Figuur 2.9

Onderwijskans per herkomstkwartiel, cohort 1961-1970

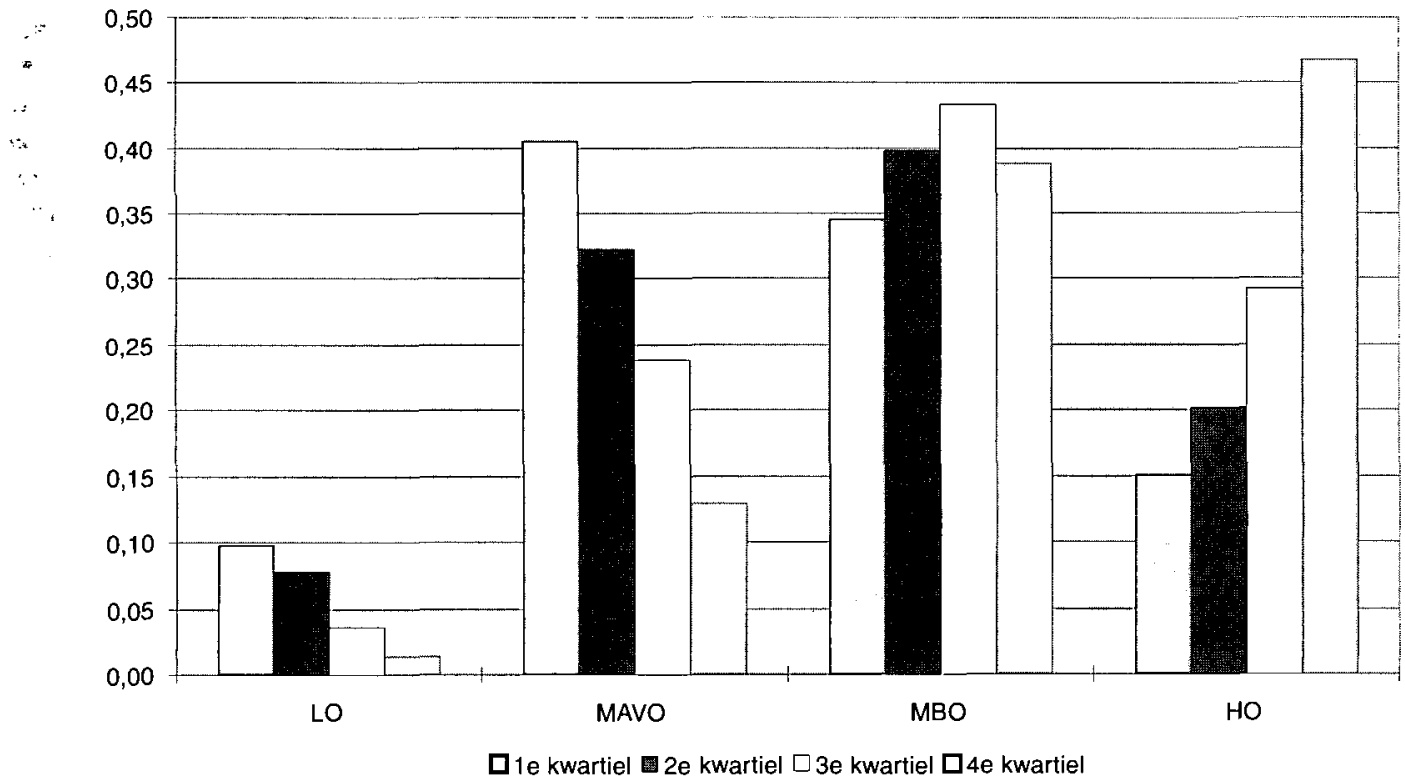

Bron: Ganzeboom, op. cit. 
Ook al bestaat er bij de verdeling van onderwijskansen al decennialang een tendens naar grotere gelijkheid, toch blijft de kans om een laag eindniveau van onderwijs te halen juist voor jongeren uit de laagste herkomstkwartielen hoog. Figuur 2.10 geeft per herkomstkwartiel weer hoe de kans van het cohort 1961-1970 om een bepaald eindniveau van onderwijs te behalen, is toegenomen ten opzichte van het cohort 1921-1930. Voor het cohort 1921-1930 waren de kansen voor de laagste herkomstkwartielen om hogere eindniveaus van onderwijs te behalen, relatief laag. $\mathrm{Nu}$ hebben alle herkomstkwartielen een min of meer gelijke onderwijskans op mbo-niveau. Hoewel de kansen op een ho-eindniveau meer zijn toegenomen dan die op een mbo-niveau, was deze toename toch niet voldoende om ook gelijke onderwijskansen op ho-niveau te creëren. De gestegen onderwijsparticipatie komt tot uitdrukking in het feit dat de kans op de hogere eindniveaus van onderwijs ook nog voor de hoogste herkomstkwartielen gestegen is.

Aan de andere kant is het opvallend dat de kans om niet meer dan een laag eindniveau van onderwijs te halen, het minst is afgenomen voor de laagste herkomstkwartielen. Tegelijkertijd heeft die groep nog steeds de grootste kans om zich tot de lage eindniveaus te beperken. Weliswaar neemt ook het aandeel van deze lage eindniveaus in het totaal af, maar de lage herkomstkwartielen raken hier eerder meer dan minder vertegenwoordigd. Dit duidt op het bestaan van een harde kern waarvoor het herkomstcriterium een belangrijke determinant blijft voor de onderwijsprestaties.

Figuur 2.10 Toename onderwijs per herkomstkwartiel, cohort 1961-1970 t.o.v. cohort 1921-1930

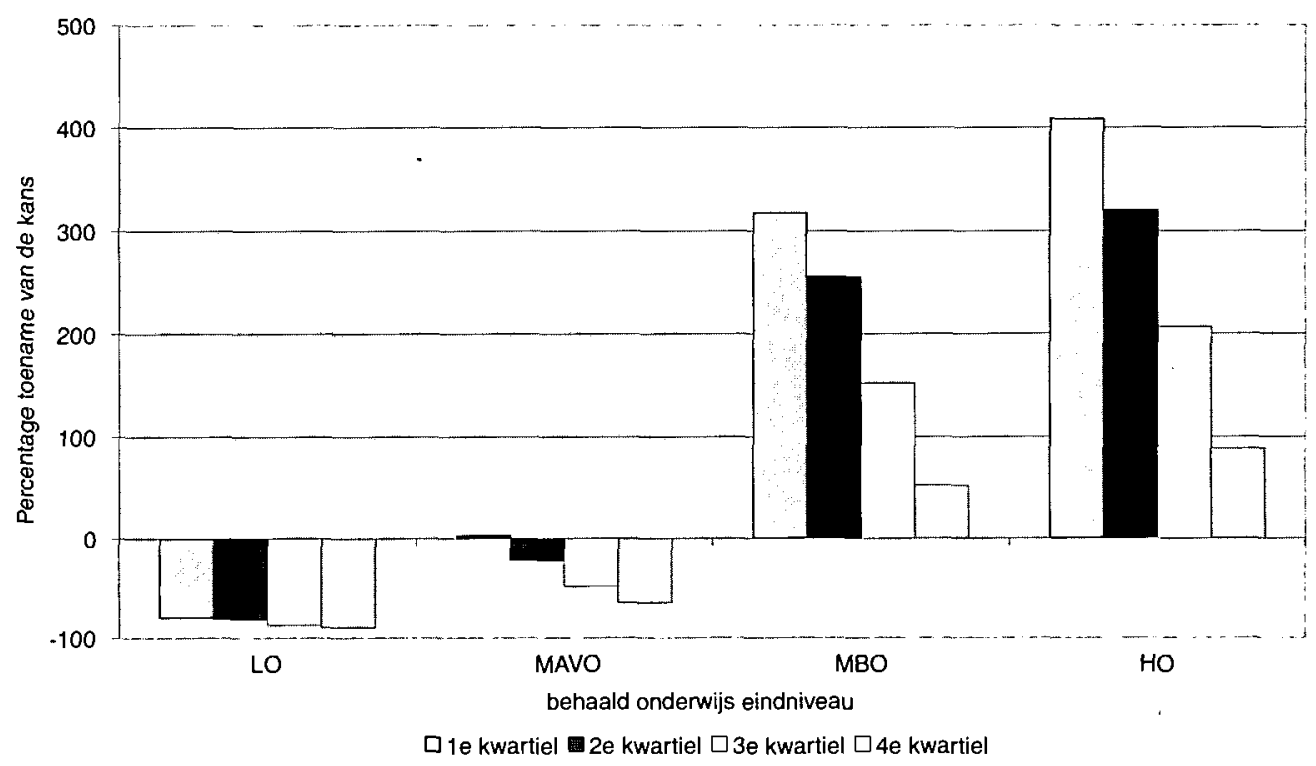

Bron: Ganzeboom, op. cit.

De invloed van het sociaal milieu van herkomst is het sterkst voor wat betreft de onderwijskeuzen op jongere leeftijd, zoals bijvoorbeeld de keuze voor beroepsonderwijs of algemeen vormend onderwijs na het basisonderwijs. Keuzen die op latere leeftijd worden gemaakt, zoals het gaan volgen van tertiair onderwijs, worden duidelijk minder beïnvloed door het sociaal milieu van herkomst. De oorzaak voor de toegenomen onderwijsmobiliteit kan voor een belangrijk deel worden gezocht in de algemene onderwijsexpansie. Met name voor het uiteindelijk bereikte onderwijsniveau is de gegroeide norm om langer 
door te leren van grote invloed om eventuele beperkingen te doorbreken, die door het sociaal milieu van herkomst worden gesteld. Men zou kunnen denken dat, als de onderwijsmobiliteit blijft toenemen, binnen een halve eeuw de invloed van dit milieu op het uiteindelijk bereikte onderwijsniveau zelfs volledig zou verdwijnen. Het valt echter te bezien of een dergelijke situatie ooit werkelijk zal ontstaan of dat dit altijd een onderwijspolitiek ideaal zal blijven. Het valt niet te ontkennen dat de vruchten van het onderwijs pas volledig rijpen, als ze ook buiten de educatieve omgeving een voedingsbodem vinden.

Gegeven het overwegend categorale onderwijsstelsel is het op doorstroming gerichte beleid van de jaren zeventig en tachtig een manier geweest om de aanvankelijke schoolniveaukeuze te kunnen bijstellen, voorzover die te zeer door traditionele factoren zoals geslacht en sociaal-economische herkomst werd bepaald. Het doorstromingsinstrument bevorderde dat leerlingen en studenten als het ware 'afstand' konden nemen van hun sociaal-economische achtergrond en hun schoolniveaukeuze meer in overeenstemming met hun talenten konden brengen. Die mogelijkheden zijn er nog steeds. Wel is het zo dat het stelsel van studiefinanciering en de wijze van bekostiging van publieke onderwijsinstellingen intussen zo zijn gewijzigd dat de geldende praktijk van doorstroming meer is beperkt. Men kan zich afvragen of, gegeven de categorale en dus relatief stands- en klassegevoelige indeling van het onderwijs, de toekomstige behoefte aan steeds hoger geschoolde arbeidskrachten niet tot een nuancering van deze beleidslijn noopt.

\subsubsection{Onderwijs en segmentatie: voorlopige conclusie}

De voornaamste conclusie van deze paragraaf moet luiden dat op de verdelingsdimensie onderwijs de ontwikkelingen in de laatste decennia zijn gegaan in de richting van grotere deelname, grotere gelijkheid van onderwijskansen en grotere opleidingsmobiliteit. 'Binnen het opleidingsgebouw', zegt Ganzeboom ${ }^{66}$, 'zijn we (...) dichter bij elkaar komen te wonen en zijn we in vergelijking met onze ouders vaker van verdieping gewisseld.' Op zichzelf is er weinig reden om aan te nemen dat deze ontwikkeling ineens zou worden gekeerd. Alleen wanneer het te verwachten rendement van onderwijs (zowel individueel als collectief) sterk zou teruglopen, zou de interesse om talent maximaal te ontplooien, kunnen afnemen. Gegeven de te verwachten ontwikkelingen op de arbeidsmarkt is hiervan echter geen sprake.

Betekent dit nu dat de toekomstige verdeling van het schaarse goed onderwijs weinig reden biedt tot zorg over segmentatie en maatschappelijke ontwrichting? $\mathrm{Al}$ eerder is gezegd dat zaken zoals tweedeling en maatschappelijke ontwrichting afhankelijk zijn van zowel objectieve als subjectieve ontwikkelingen, van feiten en van opvattingen, inclusief hun onderlinge relatie. De hierboven geschetste relatief positieve ontwikkelingen op de verdelingsdimensie onderwijs onderstrepen dat het gelijkekansenmotief in toenemende mate 'meritocratisch' wordt opgevat. Natuurlijk loopt ook een dergelijke invulling van het gelijkekansenmotief uit op nieuwe vormen van sociale ongelijkheid ${ }^{67}$. Naar de mate echter dat dergelijke opvattingen maatschappelijke acceptatie verwerven (hetgeen in toenemende mate het geval lijkt te zijn), zijn ook de daaruit voortkomende verschillen niet noodzakelijkerwijs een bron van ontwrichting. Zeker als de maatschappelijke-kansenhorizon verruimt, zal het weer een tijd duren voordat de bezorgdheid over ongelijke resultaten het zal winnen van de oriëntatie op gelijke kansen. Pas dan zal - net zoals in het afgelopen decennium - er opnieuw reden tot zorg kunnen zijn over maatschappe-

66] Ibid.

${ }^{67}$ ] Vgl. eerder citaat $\operatorname{Van}$ Kemenade: 'Het resultaat is dat er in feite sprake is van gelijke kansen op sociale ongelijkheid'. Zie Van Kemenade (1970), op. cit. 
lijke ontwrichting. Dat momenteel een serieuze segmentatiedreiging vanuit het onderwijs zou bestaan, is evenwel weinig aannemelijk. In hoofdstuk 4 wordt deze thematiek weer opgepakt.

Overigens zal de maatschappelijke druk tot nadere differentiatie en pluriformering ook in het onderwijs tot een gevarieerder pakket van opleidingen leiden, waardoor de spreiding van onderwijsniveaus weer wat zou kunnen toenemen. De Raad verwacht bovendien dat gedurende de komende decennia een brede herwaardering zal plaatsvinden voor 'vorming' en voor de maatschappelijke en economische functie van vormend onderwijs, zowel algemeen vormend onderwijs als algemeen beroepsvormend onderwijs; dat hierdoor meer ruimte zal ontstaan voor kortdurende specialistische opleidingen die de snelle veranderingen in economische productie kunnen bijbenen; dat de bekostigingsverantwoordelijkheid voor het onderwijs zich meer langs de lijnen zal gaan bewegen van initiërend/vormend versus specialistisch/beroepsspecifiek; dat met name voor de laatste categorie opleidingen ook individuen in die bekostigingsverantwoordelijkheid zullen worden betrokken; en dat de discussie over de randvoorwaardelijke verantwoordelijkheid van de overheid voor het onderwijs zich verder zal uitkristalliseren. Dat zich voor het jaar 2015 in de onderwijsprovincie - ondanks de voortgaande trend van grotere deelname en hogere gemiddelde scholing - toch grote veranderingen zullen voordoen, lijkt dus al met al geen onzinnige gedachte.

\subsection{Inkomensverdeling}

\subsection{Inleiding}

In de Nederlandse politiek van de jaren zeventig en tachtig is inkomen ongetwijfeld het belangrijkste te verdelen goed geweest. Vrijwel elke maatregel werd bezien op zijn consequenties voor de inkomensverdeling en op zijn inkomenseffecten voor specifieke bevolkingsgroepen. Het inmiddels beruchte 'koopkrachtplaatje' is jarenlang niet weg te denken geweest. Uit deze aandacht voor inkomen en inkomensverdeling spreekt een grote behoefte om de samenhang in de samenleving niet al te zeer te belasten met grote inkomensverschillen. Een zekere gelijkmatigheid van de inkomensverdeling en het tegengaan van grote inkomensverschillen worden hierbij beschouwd als evenzovele tekenen van beschaving.

Niettemin wordt sinds de jaren tachtig steeds vaker de opvatting geuit dat inkomensverschillen nodig zijn om individuen aan te zetten tot grotere economische prestaties. Ook in de politiek klonk zo het pleidooi voor een ruimere mate van loondifferentiatie regelmatig door. Tegelijkertijd werd de relatie van inkomen met arbeid weer nauwer aangehaald. Inkomensverdeling en economische dynamiek werden vanaf dat moment nadrukkelijk met elkaar verbonden. Er kwam kritiek op wat ooit als verworvenheid was beschouwd. Dat de laagste loonschalen in de CAO's 10 tot 20 procent boven het wettelijk minimumloon lagen, was bijvoorbeeld zo'n verworvenheid die ineens in haar tegendeel leek te verkeren. Ook het wettelijk minimumloon mocht dan een verworvenheid heten, maar het bleef niet langer onopgemerkt dat hierdoor heel wat maatschappelijk zinvol werk niet meer kon en mocht worden vervuld. En ten slotte werden steeds meer vraagtekens geplaatst bij het systeem van kostwinnersvergoedingen, omdat dit systeem er nu juist toe zou bijdragen dat vrouwen uit het arbeidsproces werden gehouden ${ }^{68}$. Kortom: waar inkomen lange tijd de belangrijkste plaats in het politieke discours over te verdelen goederen had ingenomen, is die plaats vanaf de jaren negentig overgenomen door arbeid: 'werk, werk, werk!' 
Na een lange periode van inkomensnivellering heeft zich medio jaren tachtig een trendbreuk voorgedaan en zijn de inkomensverschillen weer gaan toenemen. Hierin volgt Nederland andere landen, vooral de Angelsaksische. Als oorzaak waarom de inkomenspositie van de lager opgeleiden daar is teruggelopen, wordt ofwel gewezen op de internationalisering van de economie en de concurrentie uit de lagelonenlanden, ofwel op de huidige technologische ontwikkeling, in het bijzonder van de informatietechnologie en de daarmee verbonden organisatorische veranderingen ${ }^{69}$. De geschilderde perspectieven zijn dikwijls somber voor de laagbetaalden en geven de indruk dat een lange periode van inkomensdenivellering in het verschiet ligt. In reactie op dit perspectief wordt er de laatste tijd op gewezen dat landen met scherpe inkomensverschillen zelden de beste economische prestaties leveren en wordt de opvatting geventileerd dat gematigde inkomensverschillen juist bijdragen aan de economische groei.

Twee kanttekeningen zijn hier op hun plaats. In de eerste plaats mag het verwondering wekken dat in de discussies over de ontwikkeling van de inkomensverdeling zoveel aandacht bestaat voor de vergelijking van inkomens op een bepaald moment en zo weinig aandacht voor de onderlinge dynamiek van die inkomens. Er is sprake van een fixatie op het statische beeld van de inkomensverdeling, terwijl het aspect van de openheid of de mobiliteit van de inkomensverdeling nauwelijks aan de orde is. Toch heeft juist openheid van de inkomensverdeling allerlei raakvlakken met beleidsterreinen die in het centrum van de actualiteit staan. De versterkte relatie tussen inkomen en arbeidsprestatie is hiervan een voorbeeld. In het activerend arbeidsmarktbeleid wordt zwaar geleund op de versterking van economische prikkels om het arbeidsaanbod beter te doen aansluiten bij de vraag. Opwaartse inkomensmobiliteit wordt daarbij gekoppeld aan succes op de arbeidsmarkt. In dit kader passen ook de initiatieven die zijn genomen om het stelsel van sociale zekerheid om te vormen van een deactiverend stelsel tot een reactiverend stelsel. De gedachtengang dat inkomen en individuele arbeidsproductiviteit directer op elkaar aansluiten, heeft ook uitlopers in de discussie om de hoogte van het inkomen naar beneden te kunnen bijstellen wanneer de latere, wellicht minder productieve, levensfase wordt bereikt (demotie) en om minder strak vast te houden aan het anciënniteitsprincipe. In het licht van al deze voorbeelden zou de hypothese kunnen worden geformuleerd dat versterking van de inkomensmobiliteit onder bepaalde voorwaarden de economische groei kan bevorderen. Ook is het niet uitgesloten dat vergroting van de mobiliteit de acceptatie van inkomensverschillen op een bepaald moment kan doen toenemen.

Een tweede kanttekening heeft eveneens van doen met de eenzijdigheden in de statische beschouwing van de inkomensverdeling. Veel van de analyses van de bewegingen op de inkomensverdeling zien over het hoofd dat het aantal inkomensverdieners in de laatste twee decennia met sprongen is gestegen. De consequenties die deze extra instroom heeft voor de scheefheid en de mobiliteit van de verdeling zijn groot, maar worden niet altijd op hun juiste waarde geschat. Doorgaans laat men het bij de constatering dat de verdeling schever en minder open is geworden en concludeert men hieruit dat er op dit punt dus van een negatieve ontwikkeling moet worden gesproken. In wat volgt zal dit beeld worden genuanceerd. 


\subsubsection{Toegankelijkheid}

Het aantal personen dat een of andere vorm van inkomen geniet, is in de loop der tijd sterk gestegen. Dit heeft demografische oorzaken: de babyboom is al geruime tijd massaal op de arbeidsmarkt aanwezig. Het aandeel van ouderen met inkomen in de bevolking is toegenomen en dat van jongeren zonder inkomen afgenomen. Bekend is ook dat de immigratie voor een toestroom naar de arbeidsmarkt heeft gezorgd. Maar er zijn ook andere dan demografische oorzaken. De emancipatie van de vrouw heeft ertoe geleid dat steeds meer vrouwen gingen deelnemen aan de arbeidsparticipatie, met als resultaat een sterk stijgend arbeidsaanbod.

Doordat de groei van de werkgelegenheid de groei van het arbeidsaanbod in de jaren zeventig en tachtig niet heeft kunnen bijbenen, werd het beroep op de sociale zekerheid navenant groter. Aangezien de meeste instromende vrouwen tevoren hadden behoord tot de categorie der 'nulverdieners' en dus geen beroep deden op de sociale zekerheid, bood hun arbeidsinstroom geen verlichting voor de kassen van de sociale zekerheid. De arbeidsuitstoot (mannen en vrouwen) kwam daarentegen wèl in de sociale zekerheid (en dus ook in de inkomensverdeling) terecht. Aan deze situatie is ook nu nog geen einde gekomen, zoals blijkt uit tabel 2.14. Dit betekent dat de inkomensverdeling een steeds groter aantal mensen is gaan omvatten. Tegenover dit grotere beroep op arbeidsmarkt en sociale zekerheid staat de stijging van de onderwijsparticipatie. Maar deze trend is niet dominant van invloed op het aandeel van de inkomenstrekkende personen in de totale bevolking, ook al niet omdat een belangrijk deel van de onderwijsvolgenden in de loop van de tijd een 'inkomen' is gaan ontvangen via de Wet op de Studiefinanciering.

Tabel 2.14 Aandeel in de totale bevolking van individuen naar economische afhankelijkheid (\%)

\begin{tabular}{lrrrrr}
\hline & 1960 & 1970 & 1980 & 1990 & 1994 \\
\hline $\begin{array}{l}\text { Personen zonder inkomen } \\
\text { waarvan }\end{array}$ & 55 & 50 & 43 & 35 & 33 \\
$\begin{array}{l}\text { jonger dan 15 jaar } \\
\text { dagonderwijs volgend }\end{array}$ & 30 & 27 & 23 & 18 & 18 \\
$\quad$ partner alleenverdiener & 22 & 5 & 8 & 8 & 8 \\
\hline $\begin{array}{l}\text { Personen met inkomen } \\
\text { waarvan }\end{array}$ & 45 & 50 & 18 & 9 & 7 \\
$\quad$ werkzame mannen & 29 & 28 & 26 & 65 & 67 \\
werkzame vrouwen & 8 & 9 & 11 & 25 & 25 \\
uitkeringstrekkers & 8 & 13 & 20 & 27 & 17 \\
\hline
\end{tabular}

Bron: Eigen berekeningen WRR, op basis van CBS en OECD.

De toestroom van het aantal nulverdieners naar de arbeidsmarkt heeft grote gevolgen voor de manier waarop moet worden gekeken naar de inkomensverdeling en naar de bewegingen op de inkomensverdeling. In de eerste plaats is het logisch dat de gewezen nulverdieners aan de onderkant van de inkomensverdeling instromen. Vaak krijgen zij kleinere deeltijdbanen of ongeschoold werk, waarvoor nu eenmaal geen hoog salaris wordt betaald. Dit heeft uiteraard tot gevolg dat de scheefheid van de inkomensverdeling toeneemt. Hieruit concluderen dat zich op het punt van de inkomensverdeling een antiegalitaire ontwikkeling aandient, is niet correct. Was het niet de bedoeling van het emancipatiebeleid dat vrouwelijke nulverdieners zouden toetreden tot de arbeidsmarkt? Dat de bestaande inkomensverdeling daarmee schever wordt, laat zich horen. Een probleem wordt dit pas als de betrokkenen zichzelf (en kinderen) van zo'n laag inkomen in het leven moeten houden. 
Iets dergelijks geldt ook voor de mobiliteit of openheid van de inkomensverdeling. De ex-nulverdieners waar het hier om gaat, hebben doorgaans een betrekkelijk lage opleiding genoten en hebben per definitie weinig arbeidservaring. Hierdoor loopt het totaal aan mobiliteit op de verdeling terug. Maar concluderen dat zich hierdoor inzake de sociale gelijkheid een negatieve ontwikkeling voordoet, is evenmin correct. Opnieuw wordt dan het effect van de vergrote instroom vergeten. De kans is dan groot dat feitelijke processen verkeerd worden beoordeeld. In de discussie over de inkomensverdeling zijn hiervan vele voorbeelden te geven.

Werden vroeger de vrouwelijke nulverdieners niet in de inkomensverdeling betrokken, omdat in de 'normale' taakverdeling de man het inkomen inbracht, tegenwoordig wordt economische zelfstandigheid ook voor en door vrouwen als nastrevenswaardig beschouwd. Deze sociaal-culturele ommezwaai maakt de longitudinale bestudering van de inkomensverdeling ingewikkelder. De vanzelfsprekendheid waarmee eertijds de nulverdieners uit de inkomensverdeling werden gelaten, was geworteld in de sociaal-culturele normaliteit van de naoorlogse huishoudensvorming. Op dezelfde manier en op basis van diezelfde sociaal-culturele normaliteit kon er in de jaren zestig volledige werkgelegenheid zijn bij een arbeidsparticipatiecijfer dat aanmerkelijk lager lag dan het huidige. Vrouwen werden immers niet meegeteld.

Zoals in de sociaal-economische discussie begrippen als volledige werkgelegenheid en werkloosheid vanwege hun sociaal-culturele afhankelijkheid steeds vaker worden vervangen door bruto- respectievelijk netto-arbeidsparticipatie (als percentages van de potentiële beroepsbevolking), zo zou ook de notie inkomensverdeling van haar traditionele sociaal-culturele bepaaldheid kunnen worden ontdaan. In zo'n 'inclusieve' of 'bruto'-inkomensverdeling zouden dan de inkomens van iedere potentiële inkomensverdiener moeten worden opgenomen, dus ook die van de nulverdieners. Alleen dan kan het effect van de vergrote instroom op scheefheid en mobiliteit op waarde worden geschat.

Het effect van deze bijgestelde statistische presentatie van inkomens en inkomensverdeling is groot. Werd in de 'exclusieve' inkomensverdeling de toenemende scheefheid als teken van anti-egalitaire tendenties beschouwd, in de 'inclusieve' inkomensverdeling wordt duidelijk dat op basis van dezelfde ontwikkelingen geen sprake is van toenemende scheefheid; eigenlijk moet op dit punt juist van een toenemende gelijkheid worden gesproken. Van de toenemende arbeidsparticipatie ondervindt de inclusieve inkomensverdeling een duidelijk nivellerende invloed, terwijl de exclusieve inkomensverdeling juist de suggestie van het tegendeel wekt. Ook de toename van het aantal uitkeringstrekkers is als een vorm van inkomensnivellering te duiden. Niet alleen doet de traditionele exclusieve presentatie van de inkomensverdeling de feitelijke ontwikkelingen geen recht, ook het andere uiterste van een inclusieve inkomensverdeling verdoezelt, geheel andere, aspecten van de sociaal-culturele werkelijkheid. Maar door ze naast elkaar te zetten lukt het de processen achter de getallen te blijven zien.

In onderstaande bespreking van de inkomensverdeling zullen deze twee vormen van statistische presentatie zoveel mogelijk naast elkaar worden gebruikt, opdat een genuanceerd oordeel kan worden geveld over de feitelijke ontwikkelingen.

Los van het bovenstaande is nog een definitiekwestie van belang voor een helder beeld van de inkomensverdeling, namelijk de precieze afbakening van wat onder inkomen moet worden verstaan. In de regel wordt onderscheid gemaakt tussen de primaire, de secundaire en de tertiaire inkomensverdeling. De primaire inkomensverdeling is gebaseerd op het verdiende of bruto-inkomen; arbeidsloon, winst uit onderneming en andere kapitaalsbeloningen zijn de 
bron van het primaire inkomen. De secundaire inkomensverdeling beziet de verdeling van inkomens nadat de ongebonden belastingen en subsidies erin zijn verwerkt. Die overdrachten zijn 'ongebonden', omdat ze niet afhankelijk zijn van de consumptie van goederen en diensten. Ze hebben betrekking op ontvangen socialezekerheidsuitkeringen en kinderbijslag, en op betaalde premies en directe belastingen. De secundaire inkomensverdeling heeft dus betrekking op het besteedbaar inkomen. De tertiaire inkomensverdeling beschouwt de verdeling na correctie voor productgebonden belastingen en subsidies, zoals de huursubsidie en de benzineaccijns. Het consumptiepatroon is dus van invloed op de tertiaire inkomensverdeling. In de herverdeling die door tertiaire inkomensverdeling wordt bewerkstelligd, speelt het onderscheiden gebruik van publieke goederen door verschillende groepen een belangrijke rol. In het vervolg gaat het steeds over de secundaire inkomensverdeling: de primaire heeft, gegeven de forse impact van de collectieve overdrachten, weinig realiteitswaarde en de tertiaire is zo afhankelijk van individuele situaties dat het spreken daarover in termen van statistische gemiddelden steeds moeilijker is geworden.

\subsubsection{Scheefheid van de verdeling}

De gebruikelijke statistische verdeling van de in Nederland verdiende of getrokken inkomens, hierboven de exclusieve inkomensverdeling genoemd, heeft een aantal decennia gestaan in het teken van een voortgaande nivellering. De loongolven in de jaren zestig en een ruime politieke aandacht voor een gelijkmatige inkomensverdeling hebben hier het nodige aan bijgedragen. In de tweede helft van de jaren tachtig heeft zich voor wat de exclusieve inkomensverdeling betreft een omslag voorgedaan in deze trend van nivellering. Veel van de gelijkmatigheid die in de loop van de tijd die inkomensverdeling was gaan kenmerken, is sindsdien weer verloren gegaan.

Zowel de scheefheid van de verdeling als de breedte waarover die verdeling zich uitstrekt, kunnen kernachtig worden uitgedrukt in termen van gemiddelde inkomens en inkomensaandelen van decielen. Wat de breedte van de verdeling aangaat, bestaan er natuurlijk altijd zeer lage en zeer hoge inkomens naast elkaar. Maar het gewicht van deze extremen in de totale populatie is zeer gering. Waar het bij de breedte van de inkomensverdeling om gaat, is hoe de inkomens van de onderste en de bovenste kwantielen zich in de verdeling tot elkaar verhouden. Een aspect, dat bij de beoordeling van die verhouding telt, is in welke mate de onderste en de bovenste kwantielen meedelen in de welvaartsstijging.

De inkomenseenheid 'inkomenstrekker' in tabel 2.15 heeft betrekking op een echtpaar dan wel een niet-gehuwde persoon. Van een werkelijk individuele inkomensverdeling is hier dus geen sprake. Uit de tabel blijkt dat de exclusieve inkomensverdeling op basis van het besteedbaar inkomen van inkomenstrekkers momenteel wat betreft scheefheid weer op het niveau staat van het begin van de jaren zeventig. Deze ontwikkeling is in verband gebracht met het feit dat uitkeringen en inkomens in de collectieve sector achterblijven bij de inkomens in de marktsector, en met de zwakke arbeidsmarktpositie van de. lager opgeleiden. Een andere oorzaak waarom de inkomensverdeling van inkomenstrekkers schever is geworden, zou ook gevonden kunnen worden in de toename van het aantal inkomenstrekkers (tweeverdieners). 


\begin{tabular}{ccccc}
\hline & 1959 & 1970 & 1981 & 1993 \\
\hline le deciel & 1,5 & 2,9 & 2,9 & 2,1 \\
2e deciel & 3,5 & 4,8 & 5,4 & 4,6 \\
3e deciel & 5,1 & 6,1 & 6,7 & 5,8 \\
4e deciel & 6,8 & 7,1 & 7,6 & 6,9 \\
5e deciel & 8,1 & 8,3 & 8,6 & 8,0 \\
6e deciel & 9,3 & 9,4 & 9,6 & 9,4 \\
7e deciel & 10,5 & 10,6 & 10,8 & 11,0 \\
8e deciel & 12,2 & 12,2 & 12,3 & 12,9 \\
9e deciel & 15,1 & 14,9 & 14,5 & 15,7 \\
l0e deciel & 27,9 & 23,7 & 21,5 & 23,5 \\
\hline
\end{tabular}

Bron: CBS

In de vorige paragraaf is aannemelijk gemaakt dat denivellering in de exclusieve inkomensverdeling ook een artefact kan zijn van de sterke stijging van het aantal inkomenstrekkende individuen. In concreto is inderdaad sprake van zo'n stijging, door de toenemende arbeidsparticipatie van vrouwen. Vrouwen werken vaak in deeltijdarbeid tegen overeenkomstig lage inkomens. In de exclusieve inkomensverdeling, op basis van het individueel inkomen, vergroten deze lage inkomens de scheefheid. Een tweede reden waarom de inkomensverdeling op basis van het individueel inkomen schever is geworden, is dat veel uitkeringen in de loop der tijd zijn geïndividualiseerd. Voorzover de inkomensverdeling op basis van het besteedbaar individueel inkomen schever is geworden, komt dit mede doordat personen zonder inkomen niet worden meegeteld.

Het is inderdaad opmerkelijk dat de inclusieve inkomensverdeling, dat wil zeggen inclusief deze nulverdieners, over de periode van 1977 tot 1994 gelijkmatiger is geworden en dus een tegenovergesteld beeld vertoont. Dit is weergegeven in tabel 2.16. De gehele populatie van individuen van 18 jaar en ouder in particuliere huishoudens, inkomenstrekkers en nulverdieners tezamen, is in deze inclusieve verdeling wederom opgedeeld in 10-procentsgroepen. De negatieve inkomens van het eerste deciel duiden onder meer op met verlies draaiende ondernemers, schuldenposities van individuen, enzovoort.

Tabel 2.16 Inclusieve inkomensverdeling op basis van het besteedbaar

inkomen van personen van 18 jaar en ouder

(percentuele inkomensaandelen)

\begin{tabular}{lccc}
\hline & 1977 & 1985 & 1994 \\
\hline le deciel & $-0,6$ & $-0,5$ & $-0,7$ \\
2e deciel & 0,0 & 0,0 & 1,2 \\
3e deciel & 0,1 & 1,7 & 4,1 \\
4e deciel & 3,8 & 5,2 & 6,1 \\
5e deciel & 8,2 & 8,1 & 8,0 \\
6e deciel & 10,8 & 10,4 & 10,0 \\
7e deciel & 13,0 & 12,5 & 12,0 \\
8e deciel & 15,6 & 15,0 & 14,5 \\
9e deciel & 19,0 & 18,5 & 17,8 \\
10e deciel & 30,2 & 29,0 & 27,0 \\
\hline
\end{tabular}

Bron: CBS. 
Deze inclusieve inkomensverdeling laat een beeld zien dat op wezenlijke punten is tegengesteld aan de traditionele statistische presentatie van de inkomensverdeling. Van een toenemende scheefheid van de inkomensverdeling op basis van individuele inkomens is hier geen sprake meer. Zou men in de presentatie nog verder teruggaan dan het jaar 1977, dan zou het beeld van toenemende gelijkmatigheid alleen maar geprononceerder worden. Het beeld dat de armen armer worden en de rijken rijker, zoals dit op basis van de exclusieve inkomensverdeling gemakkelijk kan ontstaan, maakt hier plaats voor het beeld dat steeds meer mensen toegang hebben tot de inkomensverdeling. Dat hierbij niettemin toch armoede kan bestaan, ligt aan de omstandigheid dat steeds meer 'nieuwe' inkomenstrekkers ook een zelfstandig huishouden moeten voeren.

In de inkomensverdeling op basis van een andere inkomenseenheid, namelijk die van het besteedbaar huishoudinkomen, zijn eventuele verschillen tussen de inkomens binnen een huishouden, met name die van tweeverdienende partners, uitgemiddeld. In het huishoudinkomen zijn de verschillende inkomens binnen een huishouden namelijk bij elkaar opgeteld. Men zou zeggen dat hierdoor de toename van de scheefheid - zoals die bij de (exclusieve) inkomensverdeling op basis van het besteedbaar inkomen van inkomenstrekkers wordt waargenomen - minder sterk aanwezig zou zijn. Toch is in de ontwikkeling van de verdeling van het besteedbaar huishoudinkomen halverwege de jaren tachtig een trendbreuk opgetreden en wel in de richting van denivellering. Tabel 2.17 geeft de inkomensverdeling op basis van het huishoudinkomen weer. De Wet op de Studiefinanciering heeft bewerkstelligd dat het aantal huishoudens met een eigen inkomen vrij abrupt is toegenomen. Hiermee is rekening mee gehouden door ook studenten die voor de invoering van die wet uitwonend waren, als aparte huishoudens te rekenen. Het is bij een onderlinge vergelijking van huishoudinkomens vrij gebruikelijk te normaliseren voor de samenstelling van het huishouden. Daarvan is hier omwille van de eenvoud afgezien.

Tabel 2.17 Inkomensverdeling op basis van het besteedbaar huishoudinkomen (percentuele aandelen)

\begin{tabular}{ccccc}
\hline & 1977 & 1983 & 1989 & 1994 \\
\hline le deciel & 2,9 & 3,0 & 2,6 & 1,8 \\
2e deciel & 5,3 & 5,4 & 4,9 & 4,5 \\
3e deciel & 6,5 & 6,6 & 6,2 & 5,7 \\
4e deciel & 7,5 & 7,5 & 7,4 & 7,0 \\
5e deciel & 8,5 & 8,5 & 8,5 & 8,4 \\
6e deciel & 9,6 & 9,6 & 9,8 & 9,9 \\
7e deciel & 10,8 & 10,8 & 11,1 & 11,4 \\
8e deciel & 12,4 & 12,4 & 12,7 & 13,2 \\
9e deciel & 14,7 & 14,6 & 15,0 & 15,6 \\
10e deciel & 21,8 & 21,6 & 21,8 & 22,6 \\
\hline
\end{tabular}

Bron: CBS.

Wanneer het huishouden als inkomenseenheid wordt gehanteerd, wordt de invloed op de scheefheid van de inkomensverdeling weliswaar gematigd, althans ten opzichte van de exclusieve inkomensverdeling van individuen. Maar ook hier is de tendens tot denivellering voor een belangrijk deel te verklaren vanuit het sterk toegenomen aantal huishoudens. Met name het aantal eenpersoonshuishoudens is sterk gegroeid (zie tabel 2.18). Deze groei hangt duidelijk samen met de afname van het aandeel nulverdieners. Juist doordat veel meer individuen een inkomen hebben verworven, zijn meer eenpersoonshuishoudens mogelijk geworden. Anderzijds geldt zeker ook voor 
eenpersoonshuishoudens dat zij zich vaak aan de onderkant van de inkomensverdeling bevinden ${ }^{70}$. De inkomensverdeling op basis van het huishoudinkomen is inclusief, omdat huishoudens zonder inkomen nu eenmaal niet kunnen bestaan. De basis van de inkomensverdeling, het aantal huishoudens, is in de loop van de tijd echter sterk uitgebreid.

Tabel 2.18 Bron van inkomsten van eenpersoonshuishoudens ( $x$ 1000)

\begin{tabular}{lrrrrr}
\hline & 1977 & 1981 & 1987 & 1992 \\
\hline Alle huishoudens ' & 4540 & 4554 & 5374 & 6309 \\
waarvan eenpersoonshuishoudens & 829 & 886 & 1362 & 2043 \\
waarvoor de belangrijkste bron van inkomsten: & & & & \\
& arbeid & 334 & 303 & 559 & 837 \\
& pensioen & 471 & 532 & 641 & 753 \\
& overige uitkeringen & 24 & 40 & 149 & 438 \\
\hline
\end{tabular}

${ }^{1}$ voor 1981 en 1987 enkel huishoudens met een volledig jaarinkomen. Bron: CBS.

In de beeldvorming over de inkomensverdeling leeft ook de idee dat de scheefheid van de inkomensverdeling op basis van het huishoudinkomen is vergroot, doordat het aantal tweeverdieners met riante salarissen is toegenomen. Onderzoek wijst echter uit dat dit geen verklaring biedt voor de toegenomen scheefheid van de inkomensverdeling ${ }^{71}$. De variëteit in de groep van tweeverdieners is dermate groot dat dit effect zich niet voordoet, of dat er door de toename van deze groep zelfs nivellering optreedt. Het is immers zeker niet zo dat het verschijnsel van het tweeverdienen zich alleen bij de hoogste inkomensposities voordoet. Ook is er nog veel spreiding in de inkomens die in tweeverdienershuishoudens worden ingebracht. Dit heeft ook te maken met de geringe ontwikkeling in de onderwijshomogamie. Naarmate tweeverdienershuishoudens meer zijn samengesteld uit personen met eenzelfde onderwijsniveau, zijn de inkomens die in het huishouden worden ingebracht meer met elkaar in lijn. Een toename van de onderwijshomogamie zou derhalve verstrekkende gevolgen voor de scheefheid van de inkomensverdeling kunnen hebben, maar van een belangrijke toename blijkt in Nederland in de afgelopen decennia geen sprake 72 .

\subsubsection{Mobiliteit}

Het beeld dat wordt opgeroepen door de hiervoor weergegeven inkomensverdelingen (de inclusieve en de exclusieve) is statisch, terwijl posities in de inkomensverdeling tijdelijk zijn: iemand kan zich best het ene jaar in een van de onderste decielen bevinden en het volgende jaar in een hoger deciel. Aan deze mobiliteit binnen de inkomensverdeling wordt doorgaans minder aandacht besteed dan aan de statische inkomensverdeling ${ }^{73}$. Toch zou het logisch zijn als bij beschouwingen over de aanvaardbaarheid van een bepaalde inkomensverdeling ook het aspect van de inkomensmobiliteit wordt betrokken. Immers, inkomensverschillen zijn in sociaal opzicht acceptabeler naarmate het perspectief bestaat dat het door eigen inspanning mogelijk is een betere inkomenspositie te verwerven.

70] W. Bos, 'Inkomens van een- en tweeverdieners'; Sociaaleconomische maondstatistiek, 1996, jrg. $13, \mathrm{nr} .7$.

7'] J. Dessens, 'Inkomensongelijkheid van huishoudens'; in: Ganzeboom en Ultee (red.), op. cit.

72] W. Jansen en H. Mulder, 'Wie trouwt met wie?'; in: Ganzeboom en Ultee (red.), op. cit.

73] Het totale inkomen gedurende de levensloop is in de economische literatuur overigens regelmatig belicht. Zie bijv.: J.H.M. Nelissen, The redistributive impoct of social security schemes on lifetime lobour income; Reeks Sociale Zekerheidswetenschap Rapporten nr. 22, Tilburg, 1993. 
Inderdaad bestaat er van jaar op jaar een zekere mate van inkomensmobiliteit. In tabel 2.19 is voor de populatie van individuen uit gezinshuishoudingen ouder dan 15 jaar weergegeven welke fracties zich tussen een aantal verschillende inkomensposities hebben bewogen. De onderscheiden posities zijn die van nulverdiener, de kwintielen van de inkomensverdeling op basis van individueel besteedbaar inkomen en het verlaten van de populatie door overlijden, emigratie of vertrek naar een bejaardentehuis.

Tabel 2.19 Inkomensmobiliteit van 1992 naar 1993 in termen van overgangskansen (\%)

\begin{tabular}{|c|c|c|c|c|c|c|c|}
\hline naar: & van: & nulverdiener & le kwintiel & 2e kwintiel & 3e kwintiel & 4e kwintiel & 5e kwintiel \\
\hline nulverdiener & & 81 & 7 & 1 & I & 0 & 0 \\
\hline le kwintiel & & 16 & 74 & 18 & 2 & 0 & 1 \\
\hline 2e kwintiel & & 2 & 15 & 64 & 11 & 1 & 0 \\
\hline 3e kwintiel & & 0 & 3 & 13 & 70 & 12 & I \\
\hline 4e kwintiel & & 0 & 0 & 2 & 13 & 74 & 9 \\
\hline 5e kwintiel & & 0 & 0 & 0 & 1 & 12 & 88 \\
\hline uit populatie & & 1 & 1 & 2 & 2 & 1 & 1 \\
\hline
\end{tabular}

Uit de cijfers komt een niet te verwaarlozen opwaartse inkomensmobiliteit naar voren. Voor een gedeelte is dit een gevolg van het feit dat er individuen uit de populatie verdwijnen en dat nulverdieners een inkomen gaan verwerven. Hierdoor verandert de relatieve positie in de inkomensverdeling van degenen die al een inkomen hadden. Maar belangrijker is dat tegenover de opwaartse mobiliteit ook een neerwaartse mobiliteit staat. Er is zelfs een zekere symmetrie te bespeuren in de opwaartse en neerwaartse mobiliteit tussen twee inkomensposities. Zo is bijvoorbeeld de kans dat iemand uit het tweede kwintiel overstapt naar het derde kwintiel (13\%) ongeveer gelijk aan de kans dat iemand uit het derde kwintiel overstapt naar het tweede kwintiel $(11 \%)$. Bij benadering is deze symmetrie tussen alle paren van inkomensposities terug te vinden.

Zoals gezegd maakt inkomensmobiliteit het bestaan van inkomensverschillen maatschappelijk acceptabeler. Het is daarom van belang dat er in het pad van de onderste kwintielen naar de hoogste kwintielen geen onoverbrugbare barrières zijn ingebouwd. Iets dergelijks zou bijvoorbeeld aan de hand zijn, indien er weliswaar zowel tussen de onderste als tussen de bovenste kwintielen onderling inkomensmobiliteit bestond, maar niet of veel minder tussen de onderste en de bovenste kwintielen. Er zouden dan als het ware twee van elkaar gescheiden groepen van inkomens zijn. Van een dergelijke situatie lijkt echter geen sprake te zijn. Eerder doet zich een andere situatie voor: naarmate men zich in een lagere inkomenskwintiel bevindt, is de kans groter om naar een hoger kwintiel door te stromen. Bij een meer gedetailleerde opsplitsing in decielen komt dit helder naar voren (zie fig. 2.11). Dit betekent dat juist het verblijf in de onderste decielen van de inkomensverdeling voor grote groepen slechts van beperkte duur is.

Het zou ook in de rede liggen als in aanvulling op het voorgaande de kans om terug te stromen naar een lager deciel groter zou zijn naarmate men zich in een hoger deciel bevindt. Bij een duidelijke relatie tussen prestatie en inkomen vergt een voortdurend verblijf in de hogere inkomensregionen immers bovengemiddelde prestaties. Toch blijkt van een dergelijk verband geen sprake te zijn. De kans om in inkomenspositie terug te vallen, neemt weliswaar toe vanaf de onderste regionen van de inkomensverdeling tot voorbij de mediaan, maar in de hogere regionen van de inkomensverdeling neemt de 
kans om in inkomenspositie terug te vallen juist weer af naarmate de relatieve inkomenspositie verbetert. Een reden hiervoor zou kunnen zijn dat de geleverde prestatie samenhangt met het vergaarde kapitaal, ofwel in de vorm van vermogen, ofwel in de vorm van menselijk kapitaal. Wie dit kapitaal eenmaal bezit, zou dan blijvend een grote kans hebben om een bovengemiddelde prestatie te leveren. Maar men kan zich afvragen of daarnaast het grotere vermogen tot zekerstelling van de eigen inkomenspositie ook geen reden is voor de afnemende neerwaartse mobiliteit in de hoogste decielen.

Figuur 2.11 Kans op verandering van relatieve inkomenspositie van jaar op jaar, gemiddeld over de periode 1990-1993

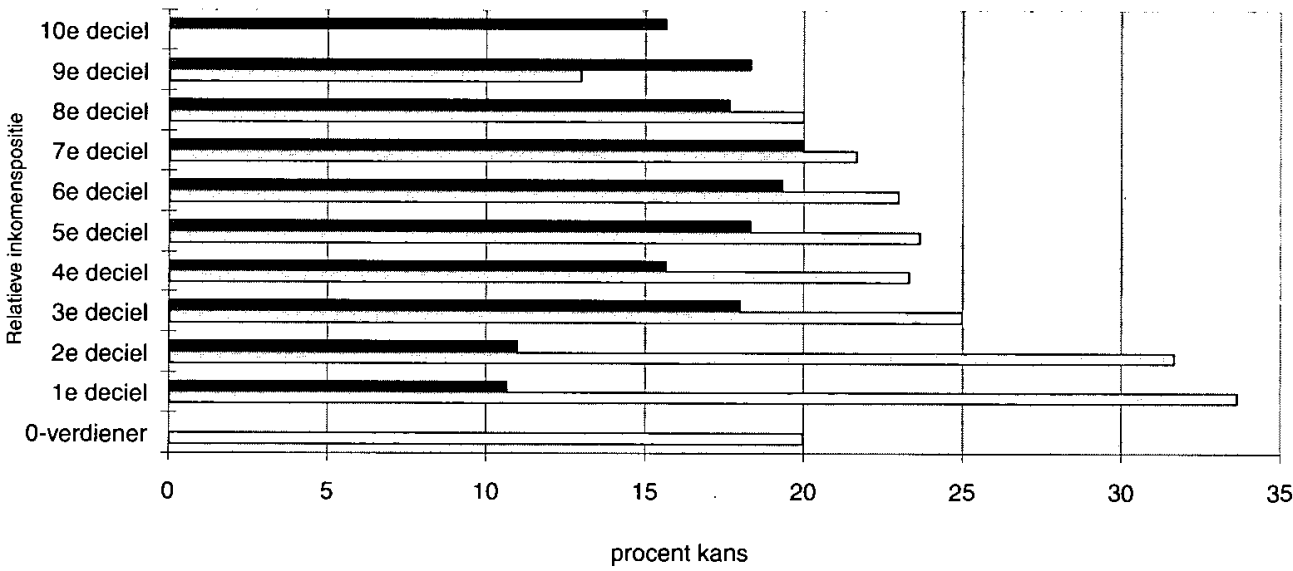

$\square$ stijging Ddaling

Bron: $\quad$ Eigen berekeningen WRR, op basis van CBS.

Opvallend is dat over de periode 1984-1993 de inkomensmobiliteit, gedefinieerd als de kans om van relatieve inkomenspositie te veranderen, aan de onderkant van de inkomensverdeling, in de laagste drie decielen, eerder afneemt dan toeneemt (zie fig. 2.12). Wellicht bestaat er een relatie met de toenemende scheefheid van de individuele inkomensverdeling. Deze is in verband gebracht met een sterke instroom aan de onderkant van de inkomensverdeling. Voor een gedeelte zou de afnemende mobiliteit ook te maken kunnen hebben met een toename van oudere uitkeringstrekkers, die immers weinig zicht op inkomensmobiliteit hebben. De oorzaak kan verder in de onderste regionen van de arbeidsmarkt gezocht worden. Het gebrek aan ervaring van herintredende vrouwen zou een rol kunnen spelen of ook een verslechterde arbeidsmarktpositie van lager opgeleiden.

Tot hiertoe is inkomensmobiliteit alleen in relatie gebracht met de maatschappelijke acceptatie van inkomensverschillen. Maar ook kan verband worden gelegd met economische efficiency. In dit verband zou een meer directe koppeling tussen arbeidsprestatie en inkomen tot meer inkomensmobiliteit kunnen leiden. De demografische ontwikkeling en met name de veroudering zou hiervoor een stimulans kunnen vormen. Tot op de dag van vandaag geeft, op basis van het anciënniteitsprincipe, leeftijd een grond voor hogere beloning. Veelal zitten juist oudere beroepsbeoefenaren aan de top van hun inkomen. $\mathrm{Bij}$ een gelijkblijvende beloningssystematiek zou dan verwacht mogen worden dat door veroudering van de beroepsbevolking het loongemiddelde zal stijgen. $\mathrm{Er}$ is echter reden om aan te nemen dat de beloningssystematiek zal veranderen. In een competitievere arbeidsmarkt, waarbij de loonverhoudingen 


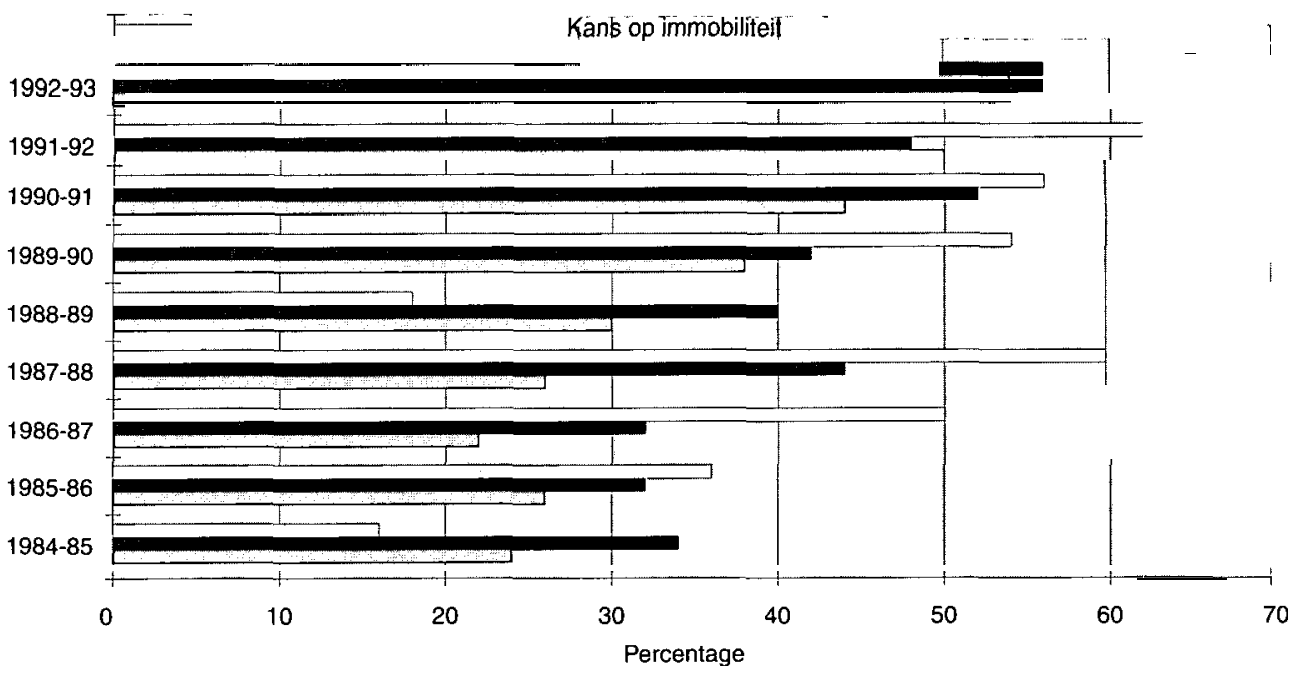

$\square$ 1e deciel $\nabla_{2 e}$ deciel $\square$ 3e deciel

Bron: $\quad$ Eigen berekeningen WRR, op basis van CBS.

minder geïnstitutionaliseerd zijn, gaat het anciënniteitsprincipe wellicht minder zwaar wegen. Om de gedachten te bepalen zijn in tabel 2.20 enige prognoses opgenomen die betrekking hebben op de CPB-scenario's Balanced Growth (BG) en European Renaissance (EUR).

Tabel 2.20

De partiële invloed van leeftijd op het bruto uurloon in guldens.

\begin{tabular}{lccc}
\hline leeftijd & 1990 & 2015 EUR & 2015 BG \\
\hline $18-19$ & 57 & 64 & 74 \\
$20-24$ & 80 & 80 & 90 \\
$25-29$ & 100 & 100 & 100 \\
$30-34$ & 111 & 108 & 105 \\
$35-49$ & 122 & 117 & 111 \\
$50-64$ & 132 & 125 & 108 \\
\hline
\end{tabular}

Bron: A.P. Deelen, De ontwikkeling van de inkomensverdeling in Nederland op lange termijn; Onderzoeksmemorandum nr. 121, Centraal Planbureau, 's-Gravenhage 1995.

Nog afgezien van de vaak geopperde gedachte dat bij ouderen de productiviteit terugloopt, kan worden vastgesteld dat zij in een situatie van snelle verandering nog eens extra in het nadeel komen te verkeren; ook hun vaardigheden verouderen dan immers sneller. En waar het op 'ervaring' aankomt: zodra ervaring een minder schaars goed wordt, zal dit ook in de beloning tot uitdrukking komen. Wil de inkomensmobiliteit zich bij ouderen niet voornamelijk in neerwaartse richting voordoen, dan zal blijvende scholing gedurende de gehele loopbaan dus onontbeerlijk zijn. 


\subsection{Samenvatting en conclusie}

In dit hoofdstuk zijn drie verdelingsdimensies aan de orde geweest die als bepalend worden gezien voor de sociale samenhang in Nederland. Op elk van deze dimensies, arbeid, onderwijs en inkomen, heeft in het recente en minder recente verleden de indruk bestaan dat zich een maatschappelijke tweedeling voordeed. Bij arbeid werd bijvoorbeeld traditioneel een scheidslijn gezien tussen handarbeiders en employees, bij onderwijs telde het milieu van sociale herkomst duidelijk mee voor de onderwijskansen en de inkomensverdeling is op zich altijd al de representatie van ongelijkheid. Maar uit de analyse in dit hoofdstuk komt naar voren dat op al deze drie verdelingsdimensies de participatie in de loop der tijd is toegenomen. Ook de ontwikkeling van de scheefheid van de verdeling op deze dimensies hoeft niet negatief geduid te worden. En er bestaat op elk van deze dimensies een behoorlijke mate van mobiliteit. Het traditionele onderscheid tussen witte en blauwe boorden is goeddeels vervaagd. De technologische vooruitgang heeft ertoe bijgedragen dat het karakter van de arbeid radicaal is veranderd. Dat heeft de mogelijkheden verruimd om meer dan voorheen aan arbeid een voldoening te ontlenen. Er is meer aandacht gekomen voor de menselijke maat van arbeid. De sterk gestegen onderwijsparticipatie heeft het belang van het milieu van sociale herkomst als determinerende factor voor het uiteindelijk behaalde onderwijsniveau sterk doen afnemen. Het behaalde niveau van onderwijs is gemiddeld gestegen en de verdeling van die niveaus heeft een veel normaler verdeling gekregen, terwijl ook de spreiding in de behaalde niveaus is afgenomen. Wat betreft de inkomensverdeling is er een lange periode van nivellering geweest. Vooral vanwege de sterke toename van het aantal inkomenstrekkers lijkt daaraan een einde te zijn gekomen. Maar als gekeken wordt naar de inclusieve inkomensverdeling moet geconstateerd worden dat de nivellering van de inkomensverdeling nog altijd doorgaat.

Het voorgaande wekt de vraag waarom, ondanks de opwaardering van de kwaliteit van arbeid, ondanks de toegenomen gelijkheid van onderwijskansen en ondanks de voortgaande nivellering van de inkomensverdeling, de dreiging van een maatschappelijke tweedeling nog steeds als reëel wordt ervaren. Wat is hier aan de hand?

Blijkbaar zijn de veranderingen in de richting van een groter aanbod en een gelijkere verdeling, zoals die op de verdelingsdimensies arbeid, inkomen en onderwijs zijn opgetreden, onvoldoende geweest om te kunnen voldoen aan de groeiende behoefte van zovelen om op deze dimensies te kunnen meedelen. In combinatie met de geringe groei van de werkgelegenheid gedurende de jaren zeventig en de dramatische terugval van de vraag naar arbeid in het begin van de jaren tachtig, heeft de sociaal-culturele omslag die zich heeft voorgedaan in de relatie van vrouwen tot de arbeidsmarkt, gezorgd voor een waar dieptepunt in de mate waarin het mogelijk was om de bestaande sociaal-economische aspiraties te vervullen. De toestroom tot elk van deze drie dimensies is zo overweldigend geweest dat de verdeling van de beschikbare middelen niet anders dan problemen kon opleveren. Die problemen kwamen voort uit een herverdeling van de beschikbare middelen op elk van de drie dimensies. Op de arbeidsmarkt heeft de krapte zich in het bijzonder gemanifesteerd aan de onderkant, waar de laagst opgeleiden hun plaats proberen te bemachtigen. De participatiegraad ligt hier beduidend lager dan bij hoger opgeleiden, terwijl voor de werkloosheidscijfers het omgekeerde geldt. In het onderwijs heeft de schaarste zich bovenal gemanifesteerd in het hoger en wetenschappelijk onderwijs. De gestegen onderwijsparticipatie heeft zijn logisch vervolg niet kunnen vinden in het oprekken van het onderwijsplafond. Op de inkomensdimensie heeft de toestroom zich vertaald in een sterke toename van lage inkomens, veroorzaakt door intreders tot de arbeidsmarkt, of de groei van het aantal uitkeringen. Het fenomeen doet zich hier dus voor dat, terwijl 
de participatie op elk van deze drie dimensies enorm is toegenomen, de nieuw ontstane situatie eerder als een verlies dan als een winst wordt ervaren.

Het is niettemin denkbaar dat, ondanks deze relativering, de bezorgdheid over een tweedeling in de samenleving, toch gerechtvaardigd is omdat in de toegenomen sociaal-economische dynamiek bepaalde zwakkere groepen het steeds moeilijker kunnen bolwerken. Doordat steeds over gemiddelden is gesproken, zouden deze groepen in de voorgaande beschouwingen buiten beeld kunnen zijn gebleven. In het volgende hoofdstuk zal daarom nader worden ingegaan op de maatschappelijke positie van groepen die als kwetsbaar kunnen worden beschouwd. 


\section{Over categorale emancipatie}

\section{I Denken in categorieën}

In het vorige hoofdstuk is nagegaan hoe de sociaal-culturele ontwikkeling zich in Nederland heeft ontwikkeld en hoe deze zich naar verwachting verder zou kunnen ontwikkelen. Dit werd nagegaan aan de hand van analyses op het terrein van beroep, onderwijs en inkomen. Met alle voorbehoud inherent aan een toekomstverkenning was de conclusie dat de Nederlandse samenleving een moeizame periode achter de rug heeft en aan de vooravond lijkt te staan van een periode waarin de perspectieven van velen ruimer en gunstiger kunnen zijn dan vaak wordt gedacht.

Deze conclusie staat op gespannen voet met tal van andere observaties ${ }^{1}$. Dat de algemene bevindingen in het vorige hoofdstuk in positieve zin afweken van de communis opinio, was wellicht terug te voeren op het daarin gebezigde niveau van analyse. Die analyse was vooral op het macroniveau gericht, op sterk geaggregeerde grootheden. Een dergelijke benadering houdt het gevaar in dat onderliggende patronen en ontwikkelingen alsmede sectorale divergenties buiten beeld blijven.

In het publieke debat over armoede en tweedeling wordt meestal vanuit categorieën gedacht. Wat zal er gebeuren met de bijstandsmoeders, die alleen van een uitkering moeten rondkomen? Hoe slecht zijn de vooruitzichten voor de groep van oudere vrouwen, die afhankelijk zijn van een AOW-uitkering? Hoe ziet de toekomst er uit voor een laaggeschoolde, die geen kans maakt op een vaste baan en die voortdurend terugvalt in de sociale zekerheid? Komen er niet steeds meer zwervers en drugsverslaafden? Welk lot wacht allochtonen die ongeschoold, slecht behuisd en vaak baanloos van een over het algemeen bescheiden inkomen moeten rondkomen?

In dit hoofdstuk wordt daarom in eerste instantie de focus gericht op die groepen die in het recente verleden veelvuldig zijn voorgekomen in het publieke debat over achterstelling, armoede en tweedeling. Gebruikelijk is om daarbij te kijken naar het inkomen en/of de schuldenpositie ${ }^{2}$. Hier wordt een breder perspectief beschouwd, namelijk maatschappelijke uitsluiting. Naast inkomen worden ook beroep en onderwijs als essentiële elementen voor maatschappelijke participatie gezien. Het gaat hierbij om grote categorieën, waarvan - anders dan bij veel jongeren/studerenden -, de eventuele achterstand niet 'vanzelf' overgaat, die in het verleden veel maatschappelijke aandacht hebben gekregen en waarvan de overheid heeft getracht de positie te verbeteren ${ }^{3}$.

Tabel 10.4 in het zojuist verschenen Socioal en Cutureel ropport 1996 laat zien dat in 1958 maar 12 procent van de mensen tussen 15 en 65 jaar bezorgd was over de toekomst. In 1980 was dat aantal opgelopen tot 40 procent, waarna een daling intrad. Vanaf 199| loopt het aandeel weer op, tot 46 procent in 1996. Zie Sociaal en Cultureel Planbureau, Socioal en Cultureel Rapport 1996; Rijswijk, 1996, blz. 469.

2] Zie Arm Nederland - het eerste jaorrapport armoede en sociale uitsluiting, door G. Engbersen, J.C. Vrooman en E. Snel (red.), 's-Gravenhage, VUGA, 1996, en J.C. Vrooman en E.P. Pommer, 'Armoede in Nederland': Economisch-Stotistische Berichten, 1996, jrg. 81, blz. $901-903$.

3] Tot de jaren zestig was het emancipatiestreven gericht op een verbetering van de maatschappelijke participatie van zeer algemene entiteiten en daarmee ook relatief grote groepen als arbeiders, katholieken of hervormden. Toen daar bij de emancipatie belangrijke voortgang was geboekt, verschoof het perspectief naar die (sub-)groepen, die nog niet aan bod hadden kunnen komen. Afgezien van de vrouwen, ging het om groepen die veel geringer in ornvang waren. Dit proces heeft geresulteerd in een voortgaande differenciatie van groepen en een versplintering van beleid om aan alle verschillen recht te doen. Steeds duidelijker wordt dat deze ontwikkeling onvruchtbaar wordt. 
Drie groepen zijn uitgekozen, namelijk vrouwen, allochtonen en ouderen. Binnen deze groepen komen deelpopulaties voor waar de problematiek van tweedeling, achterstand en onvoldoende maatschappelijke participatie pregnant naar voren komt. Naar vervolgens zal blijken, zijn ook binnen deze deelpopulaties weer subgroepen te onderscheiden. Op deze waarneming, dat een poging tot categorisering niet op groepsniveau is af te ronden, maar pas op het niveau van het individu, zal in het volgende hoofdstuk worden teruggekomen. In dit hoofdstuk wordt slechts de eerste stap, op het niveau van categorieën dus, gezet. Dit hangt ook samen met de observatie dat de maatschappelijke aandacht voor emancipatie in de achter ons liggende periode zich eveneens op dit niveau heeft gericht. De emancipatie van de vrouwen was vanaf de jaren zeventig belangrijk, in de jaren tachtig kwam daar de emancipatie van allochtonen bij en in de jaren negentig is meer aandacht gekomen voor ouderen ${ }^{4}$. Meer dan andere groepen in de samenleving zijn deze categorieën opgenomen geraakt in een breed emancipatieproces, begeleid door tal van overheidsinterventies en veranderingen in wet- en regelgeving. Dit roept de vraag op hoe succesvol deze interventies zijn geweest en welke toekomstperspectieven elk van deze groepen nu heeft. Voor iedere groep zal worden nagegaan in hoeverre door het ontbreken van kansen bij beroep, onderwijs dan wel inkomen, de maatschappelijke participatie onder druk staat.

De maatschappelijke verdeling van beroep, onderwijs en inkomen, en zeker ook de ongelijkheid daarin, kristalliseert zich niet alleen op onderscheiden wijze uit naar bevolkingsgroep, maar kent ook een ruimtelijke dimensie. Naast rijke zijn er armere regio's, naast welvarende gemeenten zijn er plaatsen met een cumulatie van maatschappelijke problemen. In de grote steden zijn de verschillen in welvaart, en mede hierdoor in maatschappelijke participatie, het meest pregnant. Naast 'armoedewijken' kent iedere gemeente zijn eigen 'goudkust'. Vandaar dat een aparte paragraaf gewijd wordt aan de problematiek in de grote steden.

In dit hoofdstuk komt naar voren dat lage scholing het gemeenschappelijk kenmerk is van non-participatie in de samenleving. Steeds weer laat toespitsing van de analyse op specifieke groepen zien dat in iedere groep 'winners' en 'losers' zijn te onderscheiden, waarbij lage scholing veelal het onderscheidend criterium is voor deze laatste groep. In de slotbeschouwing van dit hoofdstuk wordt daarom nader op dit kenmerk ingegaan. Aangegeven wordt dat samenleving en overheid er steeds van zijn uitgegaan dat ook de groep met lage scholing zich zou kunnen emanciperen. Als het niet direct via de arbeidsmarkt lukte, dan, zo was de veronderstelling, zou herkansing mogelijk zijn via om-, her- en bijscholing. Mocht ook dat traject geen baat bieden, dan was er nog de inkomenssteun via de sociale zekerheid. Dat men daarmee haast definitief van maatschappelijke participatie was uitgesloten, werd gelaten geaccepteerd. Onvoldoende werd onderkend dat de basispremisse - mensen kunnen bijgeschoold worden - voor velen in deze groep niet realistisch is. Extra opleidingsinspanningen zijn dan verspilde moeite. Vandaar dat in de slotparagraaf betoogd wordt dat een keuze voor meer maatschappelijke participatie, voor het tegengaan van tweedeling, een andere invulling van het overheidsbeleid impliceert.

Er is nog een groep die op grond van de eerder genoemde criteria - mate van non-participatie, structureel karakter, enz. - in dit hoofdstuk behandeld zou moeten worden, namelijk die van de zwervers, thuislozen, drop-outs, psychiatrische patiënten en verslaafden. Het gaat hier om een uiterst heterogeen

4] Hoe belangrijk de emancipatie van deze groepen is, kan men afleiden aan het aantal organisaties en commissies dat zich hiermee bezighoudt, de omvang van de kosten van overheidsbeleid in deze en de frequentie waarmee deze groepen in het debat over tweedeling figureren. 
gezelschap. Voorzover dat uit de schaarse gegevens blijkt, gaat het om een groep van ongeveer 20.000 mensen, net één promille van de totale bevolking 5 . Hoe gering dat ook lijkt, daarmee is deze groep toch nog niet te verwaarlozen. De indruk bestaat dat hun aantal toeneemt. Die toename hangt mede samen met de groei van het aantal drugsverslaafden en van psychiatrische patiënten zonder opvang. Er bestaat een sterke verwevenheid van persoonlijke problemen en maatschappelijk minder wenselijke gevolgen - betreffende gezondheidszorg, criminaliteit, vervuiling, confrontatie met bedelaars, enz. Het gaat veelal om mannen, maar in toenemende mate ook om vrouwen. Juist vanwege de samenhang met verslaving, neemt ook het aantal jongeren onder hen toe. Qua omvang mag hier dan sprake zijn van een kleine groep, in de beeldvorming komen ze prominent naar voren. Dat heeft deels te maken met de aandacht (en de daarbij behorende kosten), die naar hen uitgaat van tal van overheidsinstanties zoals politie, justitie, en eerstelijnshulpdiensten zoals GGD's, RIAGG's, huisartsen, en van opvangcentra zoals het Leger des Heils. Kleine criminaliteit en een gevoel van onveiligheid zijn nauw geassocieerd met drugsverslaving. Maar deels is de aandacht ook terug te voeren op het maatschappelijke onvermogen om daadwerkelijk de participatie van deze groep te verbeteren. Hun gemeenschappelijk kenmerk is dat zij er niet in slagen een stabiele positie in de maatschappij te bereiken dan wel te behouden, waar het gaat om onderwijs, beroep, inkomen dan wel huisvesting. Het gevolg is niet zelden vereenzaming, verwaarlozing en onaangepast gedrag. Juist bij deze groep wordt duidelijk dat het niet iedereen gegeven is om in een samenleving met kansen succesvol te opereren. Daar waar de overheid in het recente verleden haar kaarten vooral heeft gezet op emancipatie van deze groepen, via het vrijwillige afkicken van verslaafden, via de overheveling van psychiatrische patiënten vanuit inrichtingen naar de ambulante zorg, via het aanbieden van werk in sociale werkplaatsen en in allerlei tijdelijke banen, moet geconstateerd worden dat veel mensen in deze groepen niet ontvankelijk zijn voor dit emancipatiestreven. Ze blijken daarmee voor het reguliere overheidsbeleid nauwelijks bereikbaar te zijn; de kloof tussen kwalificatie en vereiste is voor velen niet (meer) te overbruggen. Dit neemt niet weg dat voortzetting van deze hulp van groot belang is. Tegelijk zal de samenleving moeten accepteren dat er altijd een groep zal zijn die niet zal kunnen voldoen aan de eisen van normale maatschappelijke participatie. Voor deze groep zal de overheidsbetrokkenheid vooral gericht moeten zijn op verzorging, op het aanbieden van huisvestings- en zorgfaciliteiten.

\subsection{Vrouwen}

\subsubsection{Arbeidsmarkt}

De emancipatie van de vrouwen in Nederland vanaf 1970 kan een schoolvoorbeeld worden genoemd van een relatief snelle en geslaagde doorbraak naar een grotere maatschappelijke participatie. Vooral op de arbeidsmarkt is de positie van vrouwen de afgelopen decennia drastisch veranderd. Tot 1970 was de arbeidsparticipatie van vrouwen in Nederland zeer laag. Dit gold vooral voor de deelname van gehuwde vrouwen met kinderen. Sindsdien is er sprake geweest van een zeer sterke toename, zeker voor de arbeidsparticipatie in personen. Terwijl de werkgelegenheid van mannen tussen 1970 en 1995 met 9 procent toenam, van 3,5 naar 3,8 miljoen personen, steeg die van vrouwen met 90 procent, van 1,2 naar ruim 2,2 miljoen. Die toename vond cohortsgewijs plaats, wat inhoudt dat in iedere nieuwe groep vrouwen die na de initiële opleiding aan een arbeidsmarktcarrière begon, meer vrouwen gingen werken èn bleven doorwerken dan in de vorige groep. 
Tabel 3.1 Netto-arbeidsparticipatie in personen van mannen en vrouwen naar leeftijd, 1972-1995.

\begin{tabular}{lcccc|cccc}
\hline & \multicolumn{4}{c|}{ Vrouwen } & \multicolumn{5}{c}{ Mannen } \\
& 1972 & 1980 & 1988 & 1995 & 1972 & 1980 & 1988 & 1995 \\
\hline $15-24$ & 51,7 & 42,7 & 40,9 & 37,2 & 60,2 & 46,1 & 42,3 & 39,9 \\
$25-34$ & 25,5 & 37,5 & 48,3 & 60,8 & 92,2 & 91,3 & 84,9 & 86,3 \\
$35-44$ & 23,8 & 31,0 & 38,9 & 50,1 & 94,9 & 92,3 & 88,7 & 89,8 \\
$45-54$ & 22,2 & 26,1 & 30,7 & 42,4 & 91,3 & 86,7 & 81,1 & 85,1 \\
$55-64$ & 14,8 & 14,0 & 10,5 & 13,0 & 76,9 & 61,1 & 42,3 & 38,8 \\
$15-64$ & 30,3 & 32,4 & 36,3 & 43,5 & 83,2 & 75,6 & 69,7 & 71,6 \\
\hline
\end{tabular}

Bron: Eigen berekeningen WRR, op basis van OECD, Labour Force Statistics; diverse jaargangen, en CBS, Enquête Beroeps-bevolking 1995; Voorburg, 1996.

Tabel 3.1 geeft de ontwikkeling weer van de netto-arbeidsparticipatie in personen tussen 1972 en 1995 . Ten overvloede wordt nogmaals gemeld dat de werkgelegenheid in deze periode wel degelijk is toegenomen, met name bij de vrouwen in deeltijdbanen, maar dat de groei van de relevante bevolkingsgroep, die van personen tussen 15 en 65 jaar, nagenoeg overeenkomstig was. Het cohorteffect bij de vrouwen is duidelijk waarneembaar. De netto-arbeidsparticipatie van mannen en vrouwen gezamenlijk in 1995 komt ongeveer overeen met die in 1972. Ruwweg kan gesteld worden dat de daling in de arbeidsparticipatie van mannen gelijk was aan de stijging bij de vrouwen. Naarmate de leeftijdsgroepen, die nu tussen de 25 en 44 jaar liggen, doorschuiven naar de oudere leeftijdsgroepen, mag verwacht worden dat in de nabije toekomst de arbeidsparticipatie van de oudere vrouwen ook belangrijk zal stijgen. $\mathrm{Bij}$ de mannen daalde de netto-arbeidsparticipatie fors, vooral bij de leeftijdsgroep tussen 55 en 64 jaar. Sinds 1988 is er sprake van een licht herstel in de leeftijdsgroepen tussen 25 en 54 jaar. Tabel 3.2 laat de invloed van het opleidingsniveau duidelijk uitkomen. Hoe jonger men is, dan wel hoe hoger de gevolgde opleiding, des te hoger de arbeidsparticipatie.

Tabel 3.2 Netto-arbeidsparticipatie van mannen en vrouwen, naar opleidingsniveau en leeftijd, 1995.

\begin{tabular}{|c|c|c|c|c|c|c|}
\hline & \multicolumn{3}{|c|}{ Vrouwen } & \multicolumn{3}{|c|}{ Mannen } \\
\hline & Laag & Midden & Hoog & Laag & Midden & Hoog \\
\hline $25-34$ & 38,7 & 65,7 & 78,2 & 80,7 & 90,2 & 86,1 \\
\hline $35-44$ & 35,4 & 52,8 & 71,6 & 82,7 & 92,3 & 94,0 \\
\hline $45-54$ & 30,6 & 49,4 & 69,6 & 76.0 & 88,6 & 92,6 \\
\hline 55.64 & 8,5 & 18,3 & 28,2 & 32,8 & 40,3 & 50,0 \\
\hline $15-64$ & 26,7 & 53,5 & 66,7 & 58,9 & 77,9 & 82,1 \\
\hline
\end{tabular}

Toelichting:

Laag = lo, mavo en lbo

Midden $=$ havo/vwo en mbo

Hoog = hbo en wo

Bron: Eigen berekeningen WRR, op basis van CBS, Enquête Beroepsbevolking 1995, Voorburg, 1996

Momenteel heeft een grote meerderheid van de vrouwen een deeltijdbaan. Dit betekent dat de ontwikkeling van de arbeidsparticipatie van vrouwen uitgedrukt in arbeidsjaren minder is toegenomen dan de participatie in personen. In 1970 bedroeg de arbeidsparticipatie in arbeidsjaren 25 procent, momenteel bedraagt ze 32 procent. Bij de vrouwen is de samenhang tussen scholingsniveau en arbeidsparticipatie veel sterker dan bij mannen. In samenhang met 
de voortgaande snelle stijging van het onderwijsniveau (zie par. 3.2.2), mag verwacht worden dat de stijging van de arbeidsparticipatie van vrouwen vooralsnog niet zal afnemen. Ook hier is sprake van een cohorteffect: naarmate vrouwen beter worden opgeleid, zullen ze vaker op de arbeidsmarkt participeren. Tegelijkertijd neemt het aantal laagopgeleide, niet-werkende vrouwen in de totale populatie af. Beide effecten zorgen voor een toenemende arbeidsparticipatie van vrouwen.

In internationaal perspectief is de arbeidsparticipatie van de Nederlandse vrouwen dichter bij het Europees gemiddelde gekomen. Dit geldt zeker voor de werkgelegenheid in personen. Nederland heeft meer deeltijdbanen dan enig ander OESO-land, zowel bij de mannen (15\%) als bij de vrouwen (65\%). Voor werkgevers en werknemers is deeltijdarbeid een aantrekkelijke optie gebleken. De toename van de werkgelegenheid van vrouwen is een gevolg geweest van ontwikkelingen aan de aanbodzijde - een sterk toenemend opleidingsniveau, het streven naar economische zelfstandigheid, het afnemend kindertal, enz. - en aan de vraagzijde, waar gewezen kan worden op de sterke groei van sectoren in de dienstverlening, waar vrouwen meer kans op werk hebben, en op het streven naar meer flexibilisering via deeltijdarbeid. Vrouwen werken voor het overgrote deel in dienstensectoren (88\%).

Een opmerkelijke bevinding is dat werkende vrouwen gemiddeld een hoger scholingsniveau hebben dan mannen. Dit is vooral terug te voeren op de bij vrouwen nauwe samenhang tussen opleiding en arbeidsdeelname. Het opleidingsniveau voor alle vrouwen tussen 15 en 65 jaar is lager dan bij de mannen, maar doordat vrouwen met een relatief geringe opleiding veel minder werken, stijgt het gemiddelde opleidingsniveau van de werkende vrouwen aanzienlijk. Terwijl bij de werkzame mannen in 1995 de verhouding hooghaaggeschoold (hbo+wo t.o.v. bo+mavo+lbo) 0,79 bedroeg, was de uitkomst bij de werkzame vrouwen $0,94^{6}$. Daartegenover staat dat vrouwen veel minder leidinggevende functies bekleden ( $18 \%$ van het totaal aantal leidinggevende functies, terwijl bij de totale beroepsbevolking het aandeel van vrouwen $36 \%$ bedraagt); dat vrouwen minder mogelijkheden hebben tot ontplooiing op de arbeidsmarkt 7 ; veel meer flexibele banen hebben (58\% van het totaal aantal flexibele banen) en in samenhang hiermee een relatief groot deel van de banen aan de onderkant van de arbeidsmarkt voor hun rekening nemen ${ }^{8}$. Die banen komen vooral voor in dienstensectoren en in kleinere ondernemingen en het betreft functies waarvoor weinig ervaring en kwalificaties vereist zijn. Dit maakt de kans groter dat deeltijdwerkenden en herintreedsters op dit soort banen terecht komen. Terwijl belangrijke arbeidsvoorwaarden voor vrouwen ongunstig zijn, met name de gerealiseerde beloning en de aanwezigheid van promotiekansen ${ }^{9}$, blijkt dat vrouwen meer plezier in het werk hebben, optimistischer zijn over het behoud van hun baan en dat hun arbeidsomstandigheden over het algemeen gunstiger zijn ${ }^{10}$.

6] Bij de totale groep mannen van 15 tot 64 jaar bedroeg deze verhouding in 1995 0,57, bij de vrouwen 0,37. Zie Centraal Bureau voor de Statistiek, Enquête Beroepsbevolking 1995; Voorburg, 1996, tabel 23.

] Zie Centraal Bureau voor de Statistiek, 'Trends in de kwaliteit van de arbeid van mannen en vrouwen'; Sociaal-culturele Berichten 1996-2, 1996.

8] Ter relativering moet wel worden opgemerkt dat het hier om een relatief klein aantal banen gaat, namelijk 10 procent van het totaal. Bij de vrouwen gaat het om ongeveer 18 procent van de banen. Zie Organisatie voor Strategisch Arbeidsmarktonderzoek, Onderste baan belicht; Werkgelegenheid aan de onderkant van de arbeidsmarkt; OSA-Werkdocument nr. 145, 's-Gravenhage, 1996.

9] Zie C.P.A. Bartels en T. de Groot, 'Economische prestaties van mannen en vrouwen'; Economisch-Statistische Berichten, 1996 , jirg. 81, blz. 808-812.

10] Zie Centraal Bureau voor de Statistiek, 'Trends in de kwaliteir van de arbeid van mannen en vrouwen', op. cit. 
Sinds 1970 is de arbeidsparticipatie van vrouwen belangrijk toegenomen en daardoor meer in lijn gekomen met de participatie van vrouwen in andere landen. In toenemende mate begint de arbeidsparticipatie van vrouwen, uitgesplitst naar leeftijdsgroepen, overeen te komen met die van mannen, zeker bij de hogergeschoolden. In hoofdstuk 2 is duidelijk geworden dat de werkgelegenheidsvooruitzichten op de langere termijn niet ongunstig zijn. Dat geldt ook voor varianten waarin een sterke toename van de arbeidsparticipatie voor vrouwen wordt verondersteld. Die toename is weer afhankelijk van de mate waarin vrouwen participeren in het onderwijs.

\subsubsection{Onderwijs}

\subsubsection{Deelname en opleidingsniveau}

Bij de deelname aan het onderwijs is momenteel sprake van een nagenoeg volledige egalisering van de verschillen tussen jongens (mannen) en meisjes (vrouwen). Nog in 1950 bestond er een aanzienlijk verschil in deelname en opleidingsniveau tussen mannen en vrouwen. Op 18-jarige leeftijd volgden meer dan tweemaal zoveel mannen als vrouwen volledig dagonderwijs, op 20jarige leeftijd was dat bijna viermaal en voor 22 - tot 24 -jarigen was dat bijna vijfmaal zoveel 11. De percentages convergeerden in de jaren vijftig, bleven enigermate stabiel in de jaren zestig en convergeerden daarna verder tot een punt waarbij de achterstand van vrouwen vrijwel geheel is ingelopen. Bij het opleidingsniveau traden de verschillen vooral bij het hbo/universitair onderwijs op; hier studeerden ruim tweemaal zoveel mannen als vrouwen af. Daarbij is opmerkelijk dat vrouwen op de hbo beter presteren dan mannen: het studierendement in alle onderscheiden sectoren ligt hoger ${ }^{12}$.

Tabel 3.3 Mannen en vrouwen naar opleidingsniveau en leeftijd, 1995

\begin{tabular}{|c|c|c|c|c|c|c|}
\hline & \multicolumn{3}{|c|}{ Vrouwen } & \multicolumn{3}{|c|}{ Mannen } \\
\hline & Laag & Midden & Hoog & Laag & Midden & Hoog \\
\hline $25-34$ & 29,3 & 46,5 & 24,2 & 30,0 & 45,2 & 24,9 \\
\hline $35-44$ & 39,6 & 38,8 & 21,5 & 29,9 & 42,2 & 27,9 \\
\hline $45-54$ & 53,2 & 30,7 & 16,0 & 35,2 & 39,1 & 25,7 \\
\hline $55-64$ & 66,3 & 24,0 & 9,8 & 41,7 & 39,6 & 18,7 \\
\hline $15-64$ & 45,8 & 37,0 & 17,1 & 37,9 & 40,5 & 21,6 \\
\hline
\end{tabular}

Toelichting:

Het totaal telt op tot 100

Laag = lo, mavo en lbo

Midden = havo/vwo en mbo

Hoog = hbo en wo

Bron: Eigen berekeningen WRR op basis van CBS (1996), Enquête Beroepsbevolking 1995.

Tabel 3.3 laat zien dat de verschillen tussen mannen en vrouwen tussen de 25 en 34 jaar verdwenen zijn, terwijl ook bij de daarop volgende leeftijdsgroep de verschillen betrekkelijk gering zijn. Naarmate de tijd voortschrijdt, zullen deze jaargroepen ook doordringen in de leeftijdsklassen boven de 45 jaar. Dit betekent dat in de overzienbare toekomst ook de vrouwen ouder dan 45 jaar qua opleidingsniveau vergelijkbaar worden aan de mannen.

11] Zie Sociaal-Culcureel Planbureau, Sociaal en Cultureel Rapport 1994; Rijswijk, 1994, blz. 332 en 333.

12] Zie Centraal Bureau voor de Statistiek, 'HBO: Vrouwen presteren beter dan mannen’; Persbericht PB96-260, Voorburg, 1996. Hierin wordt verwezen naar een binnenkort te verschijnen artikel in het Kwartaalschrift Onderwijsstatistieken I996-IV. 
Waar de verschillen in opleidingsdeelname en -niveau sterk zijn teruggelopen en naar verwachting nog verder zullen afnemen, blijken de verschillen in opleidingsrichting persistenter te zijn. Weliswaar laten berekeningen van het SCP zien dat ook hier de verschillen tussen 1950 en nu behoorlijk zijn afgenomen, maar voor de drie onderscheiden opleidingsniveaus (mbo, hbo, wo) is de laatste jaren een tendens naar stabilisatie waarneembaar ${ }^{13}$. Tabel 3.4 geeft de situatie in 1991/1992 weer. De mannen overwegen op alle niveaus binnen de technische richtingen, de vrouwen binnen de medisch-verzorgende en de sociale studierichtingen en bij de humaniora.

Tabel 3.4 Mannen en vrouwen naar onderwijsdeelname in mbo, hobo en wo, 1991/1992

\begin{tabular}{|c|c|c|c|c|c|c|c|c|c|}
\hline & Techn. & $\begin{array}{l}\text { Wisk. } \\
+ \text { nat. }\end{array}$ & Agrar. & $\begin{array}{c}\text { Med. } \\
\text { + verz. }\end{array}$ & Econ. & Juridisch & $\begin{array}{l}\text { Huma- } \\
\text { niora* }\end{array}$ & Sociaal & Totaa \\
\hline \multicolumn{10}{|l|}{ mbo } \\
\hline Mannen & 53 & & 8 & 6 & 34 & & & & 100 \\
\hline Vrouwen & 9 & & 3 & 50 & 39 & & & & 100 \\
\hline \multicolumn{10}{|l|}{ hbo } \\
\hline Mannen & 39 & & 6 & 4 & 31 & & 16 & 4 & 100 \\
\hline Vrouwen & 7 & & 2 & 15 & 27 & & 34 & 15 & 100 \\
\hline \multicolumn{10}{|l|}{ wo } \\
\hline Mannen & 23 & 9 & 3 & 7 & 21 & 14 & 10 & 14 & 100 \\
\hline Vrouwen & 5 & 5 & 3 & 12 & 8 & 17 & 24 & 27 & 100 \\
\hline
\end{tabular}

Noot: (a) In het hbo pedagogisch en kunstonderwijs

Bron: Sociaal Cultureel Planbureau (1994), Sociaal en Cultureel Rapport 1994, blz. 334.

Deze divergentie in opleidingsrichting heeft consequenties voor de latere beroepskansen. De keuze van onderwijsrichting is van belang vanwege de hieruit voortvloeiende verdeling naar beroep en functie 14. De spreiding van vrouwen over beroepen blijkt geringer dan die van mannen, hetgeen tot een grotere kwetsbaarheid voor eerstgenoemde groep leidt. Er ontstaan typische vrouwenberoepen, die over het algemeen minder beloond worden dan mannenberoepen. Ook zijn de opleidingsrichtingen waarvoor vrouwen een voorkeur hebben, vaak minder gunstig vanuit het perspectief van arbeidsmarktkansen.

Voor de divergentie in schoolkeuzen tussen jongens en meisjes bestaan een aantal sociaal-wetenschappelijke verklaringen ${ }^{15}$. Drie factoren komen daarin naar voren. In de eerste plaats moet het sexe-specifieke beroepsbeeld genoemd worden dat in onze samenleving bestaat en waarin het opgroeiende kind wordt gesocialiseerd. Binnen dat complex van opvattingen bestaan vakken, opleidingen en beroepen die 'passend' zijn voor meisjes en andere die dat

13] Zie Sociaal-Cultureel Planbureau (1994), op. cit., blz 335.

14] Zie hierover M. Niphuis-Nell, De emonsipotie van meisjes en jonge vrouwen; Rapportage ten behoeve van een evaluatie van het meisjesbeleid, Rijswijk, Sociaal en Cultureel Planbureau/VUGA Cahier 88, 1992; en L. Groox, 'De onderwijs- en beroepssegregatie tussen mannen en vrouwen in de eerste helft van de jaren tachtig'; Tijdschrift voor orbeidsvroogstukken, 1990, jrg. 6. nr. 4, blz. 5-25.

15] Zie Niphuis-Nell, op. cit., blz. 52 e.v. 
niet zijn. De ervaring leert dat er voor jongens een ruimer scala van mogelijkheden bestaat dan voor meisjes. In de tweede plaats is er het voorbeeld van de moeder. Er zijn aanwijzingen dat meisjes geneigd zijn om voor hun opleidings- of beroepskeuze hun moeder als voorbeeld te kiezen ${ }^{16}$. Naarmate meer vrouwen blijven werken, zal deze factor in belang afnemen. In de derde plaats zijn meisjes bij het maken van een opleidings- en beroepskeuze meer dan jongens geneigd rekening te houden met het gegeven dat zij later naast hun beroepstaak ook huishoudelijke en verzorgende taken zullen verrichten. Ook deze factor lijkt echter in belang af te nemen. Wordt vanuit deze visie naar de toekomst gekeken, dan is te verwachten dat ook in 2015 nog een zekere divergentie tussen mannen en vrouwen in opleidingsrichting en daarmee in beroepsperspectief op zal treden; die verschillen zullen echter geringer zijn dan nu.

\subsubsection{Niet betaalde (zorg-)arbeid}

Tot op de dag van vandaag is de rolverdeling tussen mannen en vrouwen bij betaald en onbetaald werk niet sexe-onafhankelijk. Nog altijd wordt betaalde arbeid voornamelijk door mannen gedaan, en onbetaalde arbeid vooral door vrouwen. Die verdeling is tussen 1975 en 1995 in lichte mate veranderd, zoals blijkt uit tabel $3.5^{17}$. Mannen hebben meer huishoudelijke taken op zich genomen, vrouwen zijn meer betaalde arbeid gaan verrichten. Wanneer apart gekeken wordt naar het tijdsbeslag van werkende vrouwen en mannen, dan blijken de verschillen beperkter te zijn ${ }^{18}$. Maar ook hier geldt dat vrouwen ongeveer twee keer zoveel tijd besteden aan het huishouden als mannen. Voor de gehele steekproef geldt dat er in de genoemde 20 jaar nauwelijks iets is veranderd in de tijdsbesteding voor huishoudelijke en gezinstaken. Blijkbaar hebben een dalend kindertal en een voortgaande monetarisering van huishoudelijke activiteiten (nog) niet geleid tot een daling van het tijdsbeslag.

Tabel 3.5 Verdeling van betaalde en onbetaalde arbeid bij vrouwen en mannen, 1975 en 1995

\begin{tabular}{lrrrr|rrrrr}
\hline & \multicolumn{4}{c}{ Vrouwen } & \multicolumn{5}{c}{ Mannen } \\
& 1975 & 1985 & 1995 & $\begin{array}{c}1995 \\
\text { werkend }\end{array}$ & 1975 & 1985 & 1995 & 1995 \\
& & & & & & & & & \\
werkend
\end{tabular}

Bron: Sociaal en Cultureel Planbureau, Sociaal en Cultureel Rapport 1996; Rijswijk, 1996, tabel B8.1, blz. 411 .

Voor de nog altijd ongelijke verdeling van taken tussen mannen en vrouwen bestaat een aantal verklaringen ${ }^{19}$. Naast de invloed van socialisatie is een voorname verklaring dat de verdeling van taken vooral bepaald wordt door het opleidingsniveau: hoe hoger de opleiding, hoe hoger de verdiensten op de arbeidsmarkt. Omdat mannen tot nu toe een hogere opleiding hadden, lag het voor de hand dat zij eerder voor betaald werk in aanmerking kwamen dan vrouwen. Deze namen het niet-betaalde huishoudelijke werk voor hun reke-

16] Zie Sociaal-Cultureel Planbureau (1994), op. cit., blz. 356 en de daar aangehaalde literatuur.

17] Zie T. van der Lippe en M. Niphuis-Nell, Ontwikkelingen in de verdeling von onbetoalde arbeid over vrouwen en mannen, 1975-1990; Rijswijk, SCP, 1994.

18] Overigens is opmerkelijk dat zowel werkende mannen als werkende vrouwen in 1995 meer tijd besteden aan huishoudelijke taken dan in 1975. Bij de mannen is dat 3 uur meer, bij de vrouwen zelfs 4 uur meer.

$\left.{ }^{19}\right]$ Zie Van der Lippe en Niphuis-Nell, op. cit., blz. I2-|5. 
ning. Nu steeds meer vrouwen een overeenkomstig opleidingsniveau hebben, zou dit ook tot een andere verdeling van huishoudelijk werk kunnen leiden. Daarenboven wordt gesteld dat naarmate men meer buitenshuis werkt, de onbetaalde arbeid in omvang zou afnemen. Deze laatste bevinding vindt ondersteuning in de SCP-data: hoe hoger de opleiding en daarmee hoe groter de deelname aan betaalde arbeid, hoe lager de tijdsbesteding aan huishoudelijke taken.

Neemt men een gelijke verdeling van betaald en onbetaald werk als uitgangspunt, dan moet de conclusie luiden dat die situatie nog lang niet is bereikt ${ }^{20}$. Realisatie van die gelijkheid zou volgens Van der Lippe en NiphuisNell moeten inhouden dat vrouwen zouden moeten streven naar grotere deeltijdbanen en mannen naar een terugdringing van de wekelijkse arbeidstijd. In dat verband is een voortgaande monetarisering van huishoudelijke activiteiten wenselijk en noodzakelijk, als faciliteit om betaald werk mogelijk te maken en tegelijk om nieuwe banen te scheppen ${ }^{21}$. Deze conclusie is ook terug te vinden in het SER-rapport Toekomstscenario's onbetaalde arbeid ${ }^{22}$. Op die wijze worden twee gunstige effecten gerealiseerd, namelijk een hogere arbeidsparticipatie van vrouwen en een toename van de werkgelegenheid. De verwachting van de SER is dat arbeidspatronen steeds flexibeler zullen worden en steeds meer zullen inspelen op de wensen en verlangens van werknemers om arbeid en zorg met elkaar te combineren.

Worden deze uitgangspunten geconfronteerd met eerdere bevindingen in dit hoofdstuk - een voortgaande stijging van de arbeidsparticipatie bij vrouwen en van het opleidingsniveau en de inverse samenhang tussen opleidingsniveau en tijdsbesteding aan huishoudelijke activiteiten -, dan mag verwacht worden dat de tijd besteed aan huishoudelijke activiteiten zal gaan afnemen, dat daarbij de verdeling tussen betaald en onbetaald werk gelijkmatiger zal worden tussen mannen en vrouwen en dat meer dan nu dergelijke taken zullen worden uitbesteed.

\subsubsection{Inkomen}

In de voorafgaande paragrafen is duidelijk geworden dat de positie van de vrouwen in de samenleving aan het veranderen is. Die veranderingen zijn ook waarneembaar bij het inkomen. Terwijl in 1977 nog 60 procent van de vrouwen geen eigen inkomensbron had, is dat percentage in 1989 teruggelopen naar 39 procent ${ }^{23}$. Arbeid is de belangrijkste inkomensbron. Hierbij valt waar te nemen dat het gemiddelde uurloon van vrouwen lager is dan van mannen, zelfs indien wordt gecorrigeerd voor verschillen in opleidings- en functieniveau en voor sectorale verschillen. Daarenboven komen vrouwen minder dan mannen in aanmerking voor extra loonelementen. Ook ontvangen relatief veel meer vrouwen dan mannen het minimumloon. Hooghiemstra en NiphuisNell stellen dat er aanwijzingen zijn dat vrouwen via functiewaardering en via de beloning gediscrimineerd worden ${ }^{24}$. Gegeven het grote aantal deeltijdbanen en het lagere inkomen per gewerkt uur, zal het geen verbazing wekken dat het verdiende bruto-inkomen per werkende bij de vrouwen beduidend lager is dan bij de mannen. De inkomensachterstand van vrouwen op mannen veranderde de afgelopen jaren nauwelijks. Die achterstand is bij jongere

20] Ibid.

2'] Ibid., blz. 57-60.

22] Zie Sociaal-Economische Raad, Toekomstscenario's onbetaalde arbeid; SER-rapport 96/06, 's-Gravenhage, 1996.

${ }^{23}$ ] Zie B.T.J. Hooghiemstra en M.J. Niphuis-Nell, Sociale atlas van de vrouw. Deel 2: Arbeid, inkomen en fociliteiten om werken en de zorg voor kinderen te combineren; Rijswijk, SCP, 1993. Gegeven de nog steeds toenemende arbeidsparticipatie, is het percentage vrouwen zonder inkomen sindsdien nog verder teruggelopen, naar ongeveer 33 procent.

24] Ibid., blz. 142-146. 
vrouwen overigens geringer dan bij oudere, hetgeen een aanwijzing zou kunnen zijn dat op termijn bij een gestage instroom van beter opgeleide vrouwen de achterstand zou kunnen afnemen.

De relatieve inkomensachterstand bij arbeid weerspiegelt zich bij de sociale zekerheid: zowel in de bijstand middels eenoudergezinnen (98\%) als bij de alleenstaanden ( $82 \%$ ) zijn vrouwen op het minimuminkomen sterk oververtegenwoordigd 25 . Ook in de onlangs verschenen studie Arm Nederland wordt duidelijk dat deze groepen, eenoudergezinnen en alleenstaande vrouwen, een verhoogd risico lopen om op of onder de armoedegrens te komen. De risico's zijn vooral hoog bij de lagergeschoolden en bij diegenen, die afhankelijk zijn van een uitkering ${ }^{26}$. Engbersen e.a. verkennen ook de gevolgen van deze situatie voor de gezondheid en de sociale participatie. De alleenstaande vrouwen laten een negatieve afwijking zien bij de deelname aan 'uitjes' en bij lidmaatschappen van verenigingen; dit hangt samen met het relatief grote aantal 65plussers. Bij gezondheid en vooral bij cultuurdeelname scoort deze groep juist sterk positief. Bij de eenoudergezinnen met vrouw wijkt de gezondheid licht negatief af, maar is er een positieve afwijking bij lidmaatschappen, cultuurdeelname en 'uitjes'. In hun conclusie merken Engbersen e.a. nog op dat factoren als leeftijd, opleidingsniveau, behoeften en mogelijkheden tot ontspanning, de woonomgeving en de etniciteit veel meer betekenis hebben voor de gezondheidstoestand en de maatschappelijke participatie dan het moeten rondkomen van een minimuminkomen ${ }^{27}$.

\subsubsection{De positie van vrouwen tot $\mathbf{2 0 1 5}$}

De maatschappelijke participatie van vrouwen is de afgelopen twintig jaar structureel veranderd. Het opleidingsniveau is belangrijk toegenomen, en mede hierdoor is de arbeidsparticipatie van vrouwen eveneens sterk verhoogd, al was dit dan vaak in deeltijdbanen. Deze veranderingen hebben tot nu toe nog niet geleid tot een belangrijke verbetering van de inkomenspositie van vrouwen ten opzichte van die van mannen. In de taakverdeling binnen huishoudens tussen mannen en vrouwen was weliswaar sprake van enige convergentie, maar nog altijd geldt dat vrouwen in veel sterkere mate hun tijd besteden aan huishoudelijke taken. Dit alles voltrok zich in een maatschappelijke omgeving die aanvankelijk terughoudend oordeelde over deze grotere maatschappelijke participatie van vrouwen, maar die in toenemende mate positief stond ten opzichte van deze ontwikkeling. Terwijl in 1965 nog 84 procent van de bevolking de arbeidsparticipatie van een gehuwde vrouw met kinderen als bezwaarlijk beoordeelde, is dat percentage in 1995 gezakt naar 16. In 1970 vond 68 procent van de Nederlandse bevolking het bezwaarlijk wanneer kinderen met een werkende moeder naar een crèche moesten, in 1995 nog 39 procent ${ }^{28}$. Ook bij de opvattingen over de taakverdeling tussen mannen en vrouwen is een verschuiving waarneembaar, al is die wel veel geleidelijker ${ }^{29}$.

Wanneer nu naar de periode tot 2015 gekeken wordt, dan is de verwachting dat de arbeidsparticipatie van vrouwen vooralsnog zal blijven toenemen. Hiervoor zijn verschillende redenen aan te geven. In paragraaf 3.2.2 is duidelijk gemaakt dat de onderwijsdeelname van vrouwen qua duur momenteel nagenoeg vergelijkbaar is met die van mannen. Het valt te verwachten dat de hoge onderwijsdeelname van deze cohorten weerspiegeld wordt in een hoge mate van arbeidsparticipatie, die ten minste vergelijkbaar is met de arbeids-

25] Ibid., blz. |51-16I.

26] Zie Engbersen e.a., op. cit.; speciaal hfdst. 2.

27] Ibid.

28] Zie Sociaal-Cultureel Planbureau (1996), op. cit., tabel 10.34 .

${ }^{29}$ ] Ibid., tabel 10.35 . 
deelname van de huidige generatie tussen 25 en 40 jaar. Naarmate de tijd voortschrijdt, zal ook in de oudere leeftijdsgroepen de arbeidsparticipatie van vrouwen gaan oplopen. Deze ontwikkeling lijkt niet in strijd te zijn met demografische verwachtingen. Er worden geen trendbreuken voorzien in de mate waarin en wanneer men gaat samenwonen dan wel trouwen, de leeftijd waarop men het eerste kind krijgt en het totale aantal kinderen dat men krijgt 30 . Ook op het sociaal-culturele vlak lijken de belemmeringen voor een verdere toename van de arbeidsparticipatie van vrouwen niet onoverkomelijk.

Eerder werd al melding gemaakt van twee recent verschenen rapporten waarin scenario's omtrent de verhouding tussen zorgarbeid en formele arbeid binnen een huishouden worden beschreven ${ }^{31}$. Zowel in de politiek als bij de sociale partners wordt het 'combinatiescenario' als het meest aantrekkelijke beschouwd 32 . In dit scenario wordt optimaal rekening gehouden met flexibeler arbeidspatronen en met de snel veranderende wensen en verlangens van werknemers om arbeid en zorg beter met elkaar te combineren. Ook de feitelijke ontwikkelingen sporen hier goed mee. De belangstelling voor deeltijdarbeid is bij vrouwen èn mannen sterk toegenomen, met name bij degenen met opgroeiende kinderen. Daarmee werd het mogelijk om binnen een huishouden bepaalde taken anders te organiseren. De toegenomen arbeidsparticipatie van vrouwen heeft gedeeltelijk geresulteerd in een verschuiving van (zorg)taken van vrouw naar man en in een grotere mate van uitbesteding. Naar verwachting zal deze trend zich verder voortzetten. Tegelijkertijd wordt een toename van het aantal banen verwacht doordat bepaalde huishoudelijke taken worden uitbesteed.

Ook al zal de maatschappelijke participatie van vrouwen verder toenemen, er zullen ook uitvallers zijn, vooral bij de lagergeschoolden. De kansen van lagergeschoolden op arbeidsparticipatie zijn beduidend lager, ook al doordat zij traditionelere opvattingen hebben over de verdeling van betaald en onbetaald werk. Als men al betaalde arbeid verricht, dan is het daarmee verdiende inkomen bescheiden. Wordt een onderscheid gemaakt naar laag-, midden- en hoogopgeleid, dan blijkt de netto-arbeidsparticipatie in personen bij vrouwen vooral bij de lagergeschoolden sterk achter te blijven. Dit geldt voor de totale groep tussen 15 en 64 jaar, maar ook voor de groep tussen 25 en 34 jaar. Als men de maatschappelijke participatie van de lagergeschoolde vrouwen wil verhogen, dan dienen aanvullende maatregelen te worden genomen. Aan het einde van dit hoofdstuk wordt hierop teruggekomen.

\subsection{Allochtonen 33}

\subsection{Inleiding}

Sinds de jaren zestig is het aandeel van de allochtonen in de bevolking belangrijk toegenomen. Volgens de ruimste definitie waren er op 1 januari 19952,6 miljoen allochtonen in Nederland. Onder deze definitie is men allochtoon als

30] Zie J. de Beer, 'Bevolkings- en huishoudensprognose 1995'; Moandstotistiek van de Bevolking, 1996, jrg. 44, nr. I, blz. 6-9.

${ }^{31}$ Z Zie Sociaal-Economische Raad (1996), op.cit., en Commissie toekomstscenario's herverdeling onbetaalde arbeid, De onbetaolde zorgarbeid herverdeeld; Ministerie van Sociale Zaken en Werkgelegenheid, 's-Gravenhage, 1995.

32] Zie de adviesaanvraag van de Minister van Sociale Zaken en Werkgelegenheid aan de Sociaal-Economische Raad en het daarop volgende rapport van de SER. Zie Sociaal-Economische Raad (1996), op.cit.

33] Ten tijde van de afronding van dit rapport heeft de Raad kennis kunnen nemen van de Rapportage Minderheden 1996 van het Sociaal en Cultureel Planbureau. De voornaamste uitkomsten van die rapportage komen overeen met de bevindingen in dit rapport: na jaren van stagnatie komt er weer enige beweging in de positie van minderheden, waarbij de differentiatie toeneemt tussen Surinamers en Antillianen aan de ene kant en Turken en Marokkanen aan de andere, met name op de arbeidsmarkt. Zie P.T.M. Tesser, F.A. van Dugteren en A. Merens, Rapportage minderheden 1996. Bevolking, orbeid, onderwijs, huisvesting, Rijswijk, SCP, 1996. 
men in het buitenland is geboren, dan wel als een of twee van de ouders in het buitenland zijn geboren. Ook de in het buitenland geboren kinderen van Nederlandse ouders tellen mee, evenals de kinderen uit gemengde huwelijken. Ook de mensen uit OESO-landen die in het kader van studie of werk naar Nederland komen, worden meegeteld. In het kader van dit rapport is een nadere toespitsing echter gewenst. Men mag ervan uitgaan dat mensen uit de meer welvarende landen goed opgeleid zijn en werk en een hoog inkomen hebben. In die zin komt de levenssituatie van deze groep goed overeen met die van de gemiddelde autochtoon en niet of nauwelijks met die van allochtonen uit niet-OESO-landen ${ }^{34}$. Telt men daarom de allochtonen uit de OESO-landen niet mee, dan resteert in Nederland een aantal van ongeveer 1,3 miljoen allochtonen die zelf zijn geboren in niet-OESO-landen of van wie ten minste één ouder dit is.

Onder deze groep vormen Turken, Marokkanen, Surinamers en Antillianen qua aantal de belangrijkste subgroepen ${ }^{35}$. Hun aantal bedraagt momenteel ruim 850.000 personen, van wie ongeveer 30 procent tot de tweede generatie behoort ${ }^{36}$. De mensen uit de tweede generatie zijn nagenoeg allemaal jonger dan 30 jaar, terwijl de eerste generatie meestal ouder dan 30 jaar is. Dit betekent dat men in het land van herkomst is opgegroeid en opgeleid. Doorgaans is men daardoor niet of nauwelijks voorbereid op een arbeidsmarktcarrière in een hoogontwikkelde samenleving als de Nederlandse. In het voorafgaande hoofdstuk is duidelijk geworden dat allochtonen bij beroep, onderwijs en inkomen, vaak slecht bedeeld zijn. Daarmee lijkt deze groep een duidelijk aparte positie in de Nederlandse samenleving in te nemen en ligt aparte aandacht voor hen in een rapport over segmentatie en tweedeling voor de hand ${ }^{37}$.

\subsubsection{Arbeidsmarkt}

De arbeidsparticipatie van allochtonen is, in vergelijking met die van autochtonen, laag, zoals tabel 3.6 laat zien. Tegelijkertijd blijkt uit dezelfde tabel dat de verschillen in arbeidsparticipatie met de autochtonen in de periode 19871995 toch licht zijn afgenomen ${ }^{38}$. De groei van de werkgelegenheid van deze groep, jaarlijks 7 procent, lag beduidend boven die van de totale bevolking. Diezelfde tabel leert ook dat de verschillen binnen de allochtonen, naar niveau en ontwikkeling, over de tijd zijn toegenomen. Tegenover Turken en Marokkanen, die een zeer lage en stagnerende arbeidsparticipatie hebben, staan Antillianen en Surinamers, met een hogere en toenemende arbeidsparticipatie. Vooral de Surinamers laten een sterke groei van de arbeidsparticipatie zien. De arbeidsparticipatie van Surinaamse vrouwen is zelfs hoger dan die van autochtone vrouwen. In contrast daarmee is de lage arbeidsparticipatie van Turken en Marokkanen voor een belangrijk deel terug te voeren op de zeer lage arbeidsparticipatie van vrouwen - in 199515 respectievelijk 12 pro-

34] Hun gunstige sociaal-economische positie weerspiegelt zich vaak ook in hun huisvestingssituatie en in de schoolkeuze voor hun kinderen. Doordat velen van hen slechts tijdelijk hier zijn, maken ze zich de Nederlandse taal niet of nauwelijks eigen, en zoeken ze geen aansluiting bij de Nederlandse maatschappij. Deze vorm van segmentatie is zelf verkozen. Om al deze redenen is het niet verstandig deze groep hier verder in de beschouwing te betrekken.

35] Ten overvloede zij opgemerkt dat nadere differentiatie van deze groepen, naar etniciteit en gebied van herkomst, nastrevenswaardig is.

36] Zie Centraal Bureau voor de Statistiek, Allochtonen in Nederland 1996; Voorburg, CBS, 1996, blz. 27.

${ }^{37}$ Overigens heeft de WRR zich al eerder uitgebreid met de allochtonenproblematiek beziggehouden. Zie WRR, Etnische minderheden; Rapporten aan de Regering nr. 17, 's-Gravenhage, Staatsuitgeverij, 1979; en WRR, Allochtonenbeleid; Rapporten aan de Regering nr. 36, 's-Gravenhage, Sdu Uitgeverij, 1989.

38] Daarbij moet wel worden opgemerkt dat de in de EBB opgenomen reeksen met betrekking tot de allochtonen met de nodige voorzichtigheid bezien moeten worden. Ze bevatten soms opmerkelijke trendbreuken. Zo daalt het totaal aantal Turken tussen 15 en 65 jaar van 1994 naar 1995 van 170.000 naar 142.000, terwij] tot dan toe sprake was van een haast continue stijging. 
cent. Deze lage arbeidsdeelname van Turkse en Marokkaanse vrouwen heeft veel te maken met de bij deze groep heersende negatieve opvattingen over werkende vrouwen, de zeer lage opleidingsniveaus van deze vrouwen en de vaak grotere omvang van de gezinnen, die deelname aan de arbeidsmarkt bemoeilijkt ${ }^{39}$.

Tabel 3.6 Netto-arbeidsparticipatie voor onderscheiden groepen, 1987-1995.

\begin{tabular}{|c|c|c|c|c|c|c|c|}
\hline & 1987 & 1989 & 1991 & 1993 & 1995 & $1995 M$ & $1995 \mathrm{~V}$ \\
\hline Autochtonen & 53.3 & 54.9 & 57.6 & 58.4 & 59.4 & 74 & 45 \\
\hline Allochtonen & 32.5 & 33.2 & 35.6 & 35.5 & 39.2 & 54 & 34 \\
\hline wr. Turken & 33.7 & 28.7 & 31.0 & 31.0 & 30.3 & 44 & 15 \\
\hline Marokkanen & 25.4 & 22.0 & 26.1 & 18.8 & 28.6 & 41 & 12 \\
\hline Surinamers & 36.4 & 41.1 & 41.5 & 47.0 & 51.1 & 56 & 46 \\
\hline Antillianen & 40.0 & 39.3 & 47.1 & 46.7 & 44.4 & 60 & 35 \\
\hline
\end{tabular}

Bron: Ministerie van Sociale Zaken en Werkgelegenheid (1995), Sociale Nota 1996, bijlage 3, en CBS (1996), Enquête Beroepsbevolking 1995.

Ook bij de allochtonen is er een duidelijk positieve samenhang tussen arbeidsparticipatie en opleidingsniveau. Tabel 3.7 laat zien dat bij de bruto-arbeidsparticipatie de uitkomsten per opleidingsniveau voor allochtonen en autochtonen nagenoeg gelijk zijn. Doordat echter het aantal laaggeschoolden onder allochtonen zo groot is, is het gemiddelde voor deze groep ook laag. Wanneer men erin slaagt om het onderwijsniveau van de allochtonen te verbeteren, dan is ook hier een verruiming van perspectief mogelijk. Bij de netto-arbeidsparticipatie zijn de verschillen groter. Dit heeft te maken met de veel hogere en nauwelijks dalende werkloosheid van allochtonen. Binnen deze groep springen opnieuw de Turken en Marokkanen er in negatieve zin uit. De situatie van de Surinamers is beter, bij hen is de werkloosheid lager en duidelijk dalende. Niet onverwacht is ook het aandeel langdurig werklozen onder Turken en Marokkanen beduidend hoger dan bij de andere allochtonen of bij de autochtonen ${ }^{40}$. Al met al is de conclusie dat allochtonen én een lagere arbeidsparticipatie èn een hogere werkloosheid, alsmede een langere werkloosheidsduur laten zien, waarbij in de periode 1987 tot 1995 de Turken en Marokkanen hun achterstand nog verder hebben zien oplopen, terwijl bij de Surinamers juist sprake is van een aanhoudende verbetering, absoluut en relatief.

Tabel 3.7 Arbeidsparticipatie van autochtonen en allochtonen naar opleidingsniveau, 1995

\begin{tabular}{lccccccc}
\hline & \multicolumn{2}{c}{ Bruto-arbeidsparticipatie } & \multicolumn{2}{c}{ Netto-arbeidsparticipatie } \\
& Laag & Midden & Hoog & Laag & Midden & Hoog \\
\hline Autochtonen & 47,4 & 71,6 & 81,1 & 43,0 & 67,4 & 76,7 \\
Allochtonen & 43,3 & 72,4 & 77,8 & 30,6 & 59,2 & 69,4 \\
\hline
\end{tabular}

Toelichting: Onder allochtonen wordt hier verstaan Surinamers,

Antillianen, Turken en Marokkanen

Laag = lo, mavo en lbo

Midden = havo/vwo en mbo

Hoog = hbo en wo

Bron: Eigen berekeningen WRR, op basis van CBS (1996), Enquête Beroepsbevolking 1995.

39] Zie J. Veenman, Participatie in perspectief. Ontwikkelingen in de socioaleconomische positie van zes allochtone groepen in Nederland; Houten, Bohn Stafleu Van Loghem, 1994, blz. 69.

40] Ibid., blz. 70 . 
Niet alleen is de arbeidsparticipatie van allochtonen geringer dan die van autochtonen, zelfs met verdiscontering van de verschillen in opleiding, maar ook blijkt de positie van werkende allochtonen zwak te zijn. Allochtonen hebben vaker een tijdelijke baan dan autochtonen ${ }^{41}$, en hun functieniveau, promotiekansen en de kwaliteit van hun arbeid zijn lager. De arbeidsmarktsituatie voor allochtonen is slecht, waarbij ook hier de Turken en Marokkanen de ongunstigste scores vertonen. Veenman laat zien dat in de rangorde van functieniveau I (zeer eenvoudige werkzaamheden) tot niveau VII (wetenschappelijke werkzaamheden), niet meer dan 7 procent van de autochtone werknemers te vinden is op niveau I, tegen 50 procent van de Turken en Marokkanen en 20 procent van de Surinamers en Antillianen/Arubanen. Ook het spiegelbeeld is te vinden: terwijl 20 procent van de autochtone werknemers zich bevindt op de niveaus VI en VII, geldt dat voor 10 procent van de Surinamers en Antillianen/Arubanen en 5 procent van de Turken en Marokkanen ${ }^{42}$. Ook is er sprake van beroepensegregatie. Allochtonen zijn oververtegenwoordigd in de industrie, waar eerder met afbouw dan met groei van werkgelegenheid moet worden gerekend, en nagenoeg afwezig in transport en in het bank- en verzekeringswezen.

Voor een verklaring van de slechte arbeidsmarktpositie van allochtonen wordt traditioneel in de eerste plaats gekeken naar het opleidingsniveau van het arbeidsaanbod. Hiervoor is al geconstateerd dat allochtonen een veel lager opleidingsniveau hebben, en dat dit vooralsnog niet zal veranderen. Het blijkt echter dat ook andere factoren dan opleiding in het geding zijn: kennis van de Nederlandse taal, het bezit van een sociaal netwerk, en verder natuurlijk de selectieprocessen onder werkgevers. Wat de laatsten betreft, lijken sociaalnormatieve criteria (vergeleken met het technisch-instrumentele criterium van de directe vakbekwaamheid) steeds belangrijker te worden. Dit werkt, zo leert de ervaring, in het nadeel van de minderheden. Daarnaast spelen ook meer directe vormen van discriminatie een rol ${ }^{43}$.

Toch zou het onverstandig zijn de beschouwing in mineur af te ronden. Allereerst is duidelijk dat bepaalde groepen allochtonen, met name de Surinamers en, zij het in mindere mate, de Antillianen en Arubanen, een duidelijke vooruitgang in arbeidsparticipatie laten zien. Maar ook bij Turken en Marokkanen zijn toch wel signalen van verbetering waarneembaar ${ }^{44}$. Naarmate allochtonen beter opgeleid zullen zijn, nemen hun kansen op werk ook toe. De eerste tekenen van verbetering op de arbeidsmarkt zijn te bespeuren. Ten opzichte van 1990 is het opleidingsniveau van allochtonen beduidend toegenomen, iets meer zelfs dan bij de autochtonen. Dat geldt voor de gehele bevolkingsgroep tussen 15 en 65 jaar, en nog sterker voor de werkenden. Met andere woorden, nog altijd is deze groep laaggeschoold ${ }^{45}$, maar er treedt verbetering op: de achterstand ten opzichte van de rest van de bevolking begint

41] Ibid., blz. 71; en Centraal Bureau voor de Statistiek, Enquête Beroepsbevolking 1995, blz. 43, tabel 6.

42] Zie Veenman, op. cit., blz. 7 I.

43] Zie K.W.H. van Beek, To be hired or not to be hired; the employer decides; proefschrift Universiteit van Amsterdam, 1993; en K.W.H. van Beek en B.M.S. van Praag, Kiezen uit sollicitonten; Concurrentie tussen werkzoekenden zonder een boon; WRR, Voorstudies en achtergronden nr. 74, 's-Gravenhage, Sdu Uitgeverij, 1992.

44] Zie J. Veraart, In vaders voetspoor. Jonge Turken op de arbeidsmarkt; Amsterdam, Thesis Publishers, 1996; A. Böcker, 'Op weg naar een beter bestaan. De ontwikkeling van de maatschappelijke positie van Turken in Nederland'; in: Het democratisch ongeduld. De emancipatie en integratie van zes doelgroepen van het minderhedenbeleid; door $\mathrm{H}$. Vermeulen en R. Penninx (red.), Amsterdam, Het Spinhuis, 1994, blz. 145-176; en F.J. Buijs en C. Nelissen, 'Tussen continuïteit en verandering. Marokkanen in Nederland'; in: Vermeulen en Penninx (red.), op.cit., blz. 177-206.

45] Volgens de EBB 1995 bedroeg het aandeel van de groep Surinamers. Antillianen. Turken en Marokkanen bij diegenen met alleen lagere school 14 procent, en bij de mensen met ten hoogste mavo 5.7 procent. Omgekeerd waren deze groepen ondervertegenwoordigd bij de mensen met een hbo- en wo-opleiding. Zie Centraal Bureau voor de Statistiek (1996), op. cit. 
in zeer bescheiden mate af te nemen ${ }^{46}$. Op de derde plaats moet rekening gehouden worden met de betekenis van etnisch ondernemerschap en informeel werk voor allochtone groepen. Juist bij allochtonen moeten de beschikbare officiële gegevens over arbeidsparticipatie met de nodige terughoudendheid bezien worden 47 . Volgens sommige waarnemers duiden recente ontwikkelingen in dit bereik op een verbetering van de positie van allochtonen, die op termijn ook zal doorwerken in de formele sfeer ${ }^{48}$.

Ten slotte is het zinvol de omvang van deze groepen in perspectief te zien. De vier onderscheiden allochtonen groepen nemen in de leeftijdsgroep tussen 15 en 65 jaar momenteel een aandeel in van ongeveer 4,6 procent, en bij de werkenden 2,6 procent ${ }^{49}$. Bij de laaggeschoolden komt het aandeel uit op 14 procent. Naar verwachting zullen deze percentages in de nabije toekomst oplopen. Toch gaat het hier om een omvang waarbij beleid nog effectief lijkt te kunnen zijn.

\subsubsection{Onderwijs}

Het opleidingsniveau van allochtonen blijkt ver achter te blijven bij dat van autochtonen. Tabel 3.8 laat zien dat vooral Turken en Marokkanen een zeer laag opleidingsniveau hebben. Weliswaar is het opleidingsniveau van Surinamers en Antillianen een stuk hoger, maar ook hier is de achterstand op de autochtonen zeer groot ${ }^{50}$. Terwijl bij de autochtone bevolking tussen 15 en 65 jaar in 1995 ongeveer 40 procent ten hoogste een lbo/mavo-niveau heeft bereikt, ligt dit percentage bij Antillianen op 46, bij Surinamers op 61, en bij Marokkanen en Turken op 83. Ten opzichte van 1990 is de situatie echter wel verbeterd. Juist bij gerealiseerd opleidingsniveau is het onderscheid tussen eerste en tweede generatie allochtonen van cruciaal belang. Over het algemeen wordt de eerste generatie gekenmerkt door een zeer laag scholingsniveau en laat de tweede generatie een duidelijke toename zien ${ }^{51}$.

Tabel 3.8 Bereikte opleidingsniveaus van de bevolking tussen 15 en 65 jaar, 1990 en 1995

\begin{tabular}{|c|c|c|c|c|c|c|c|c|}
\hline & \multicolumn{2}{|c|}{ max. basisonderwijs } & \multicolumn{2}{|c|}{ Ibo/-mavo } & \multicolumn{2}{|c|}{ mbo/-havo/-vwo } & \multicolumn{2}{|c|}{ hbo-/wo } \\
\hline & 1990 & 1995 & 1990 & 1995 & 1990 & 1995 & 1990 & 1995 \\
\hline Autochtonen & 17 & 13 & 30 & 27 & 37 & 40 & 16 & 20 \\
\hline Allochtonen & 54 & 45 & 24 & 27 & 17 & 20 & 5 & 8 \\
\hline wv. Turken & 69 & 61 & 21 & 23 &.. & 14 & .. & . \\
\hline Marokkanen & 73 & 64 & 16 & 19 &.. &.. & .. & .. \\
\hline Surinamers & 36 & 27 & 31 & 34 & 25 & 27 & 8 & 12 \\
\hline Antilianen & 21 & 18 & .. & 29 & 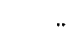 & .. & .. & .. \\
\hline
\end{tabular}

Toelichting: .. betekent dat er geen cijfers worden gepubliceerd door het CBS.

Bron: Eigen berekeningen WRR op basis van CBS, Enquête Beroepsbevolking 1995.

46] Bij de overige allochtonen, over het algemeen mensen uit de OESO-landen, ligt het gemiddeld opleidingsniveau juist beduidend hoger dan bij de autochtonen. Zie Centraal Bureau voor de Statistiek (1996), op. cit.

47 Zie R. Kloosterman, J.P. van der Leun en J. Rath, Immigranten en de informele economie; Amsterdam/Utrecht, IMES/ERCOMER, 1996.

${ }^{48}$ ] Zie J. Rath, 'Beunhazen van buiten: De informele economie als bastaardsfeer van sociale integratie'; in: Sferen van integratie. Naar een gedifferentieerd allochtonenbeleid; door G. Engbersen en R. Gabriels (red.), Meppel, Boom, 1995, hfdst. 3, blz. 74-109.

49] Deze en andere cijfers over omvang bevolking en werkgelegenheid zijn afkomstig uit de EBB I995. Zie Centraal Bureau voor de Statistiek (1996), op.cit.

50] Deze uitkomsten sporen met die voor de EBB 1995. In het laatste geval zijn echter gegevens per afzonderlijke bevolkingsgroep niet te berekenen.

5I] Zie Veenman, op. cit., appendix B, tabel 5. 
Veenman merkt op dat de onderwijspositie van allochtonen de afgelopen jaren aanmerkelijk is verbeterd ${ }^{52}$. Hij baseert zich daarbij op een aantal bevindingen. $Z_{0}$ is er een duidelijke verhoging van het opleidingsniveau - zeker van diegenen die in Nederland onderwijs volgden -, de deelnemingsgraad neemt toe, er is een betere doorstroom naar hbo/wo, de leeftijdsachterstand aan het einde van de basisschool is geringer en de drop-out cijfers dalen.

Tegelijkertijd constateert Veenman echter dat de opleidingsachterstand ten opzichte van autochtone leeftijdsgenoten verder is toegenomen. Autochtone jongeren hebben namelijk nog snellere vorderingen gemaakt. Als gevolg hiervan is de achterstand van jonge allochtonen ten opzichte van hun autochtone leeftijdgenoten nog groter dan bij de ouderen. Veenman voert verschillende oorzaken aan: migratiekenmerken (onvoldoende beheersing van het Nederlands, maar ook bijvoorbeeld het verwachtingspatroon ten opzichte van onderwijs) die pas na een aantal generaties verdwijnen, de lage sociaal-economische positie die een moeizame start betekent en, in veel geringere mate, de kenmerken van de scholen die door allochtonen bezocht worden ${ }^{53}$. Tesser komt met overeenkomstige argumenten en noemt daarnaast de concentratie van allochtone kinderen op een beperkt aantal scholen, de keuze voor een te hoog schooltype in het voorbereidend onderwijs en de onderwijskundige tekorten op de scholen ${ }^{54}$. Alle genoemde factoren zijn terug te voeren tot immigratiebepaalde dan wel structurele factoren. De immigratiebepaalde factoren zullen in de loop van de tijd aan betekenis verliezen, althans voor de reeds aanwezige allochtonen ${ }^{55}$. Bij de structurele factoren is de lage sociaal-economische positie uiterst belangrijk. Als allochtonen er niet in slagen hun opleidingsachterstand ten opzichte van de autochtone jeugd te verminderen, zou zelfs een negatieve ontwikkeling kunnen optreden: laag opgeleiden komen dan terecht aan de onderkant van de beroepenladder, zij geven hun kinderen weinig cognitieve ondersteuning, met als gevolg dat die ook weer deze cyclus zullen doorlopen. Gelet op de huidige, en voor de overzienbare toekomst gecontinueerde, concentratie van allochtonen in bepaalde wijken in de grote steden en gegeven het observeerbare gedrag van ouders om bij de keuze van een basisschool rekening te houden met de mate van aanwezigheid van allochtonen, zal de bestaande concentratie van allochtone kinderen op een beperkt aantal scholen waarschijnlijk blijven bestaan.

Tegenover deze opvatting, namelijk dat de achterstand van allochtonen op autochtonen eerder nog vergroot dan verkleind is, stellen Diederen en Dronkers dat migrantenleerlingen op de basisschool tussen 1982 en 1989 niet verder achterop zijn geraakt ten opzichte van autochtone leerlingen ${ }^{56}$. Ook al zijn de verschillen niet afgenomen, toch achten Diederen en Dronkers op termijn verbetering mogelijk: de migrantenstatus of een afwijkende etnische cultuur leiden niet onvermijdelijk tot onderwijsachterstand.

Deze tegenstrijdige bevinding, een toenemende achterstand van allochtone leerlingen ten opzichte van autochtonen dan wel een stabilisatie, komt ook naar voren in het oordeel over het onderwijsvoorrangsbeleid. Duidelijk is dat die oordelen uiteen lopen. In het rapport Allochtonenbeleid sprak de WRR van

52] lbid.

53] Ibid., blz. I3.

54] Zie P.T.M. Tesser, Rapportage minderheden 1993; Rijswijk, SCP, 1993, blz. 185 e.v. Ook in de zojuist verschenen Rapportage minderheden 1996 is het oordeel van Tesser e.a. over de onderwijsprestaties van de minderheden, in het basisonderwijs en in de eerste fase van het voorgezet onderwijs, onverminderd pessimistisch.

55] Voor nieuwe generaties van immigranten gaat dit niet op.

${ }^{56}$ ] Zie H.M.N. Diederen en J. Dronkers, 'Achterblijven, inhalen of voorbijstreven? De verbetering van de onderwijskansen van kinderen van migranten gedurende de jaren tachtig in vergelijking met die van autochtone kinderen'; Migrantenstudies, 1996. jrg. I, nr. 3, blz. 118.135 . 
een weinig doelgerichte inzet van middelen ${ }^{57}$. Ook in latere onderzoeken wordt een dergelijke opvatting verkondigd ${ }^{58}$. Bij Veenman lijkt geleidelijk een positiever oordeel door te breken ${ }^{59}$. Anderen, zoals Driessen en Van der Werf, betogen dat de kansen van de allochtonen, mede onder invloed van het onderwijsvoorrangsbeleid, in ieder geval niet verslechterd zijn ${ }^{60}$. Ook moet rekening worden gehouden met regionale verschillen. Zo zijn de signalen wat betreft de effectiviteit van het onderwijsvoorrangsbeleid voor Rotterdam gunstiger dan voor Amsterdam. Diederen en Dronkers wijzen erop dat dergelijke inhaalbewegingen ook hun tijd nodig hebben. Het is naar hun mening kortzichtig en getuigend van politiek ongeduld om reeds binnen een periode van tien jaar significante verbeteringen te verwachten.

\subsubsection{Inkomen}

Met een laag opleidingsniveau en een relatief geringe arbeidsparticipatie, en dan nog vooral in lagere functies, mag het geen verwondering wekken dat ook het inkomen van allochtonen ten opzichte van dat van autochtonen laag is ${ }^{61}$. Het nettomaandinkomen van diegenen met een werkweek tussen 35 en 45 uur blijkt bij allochtonen veel lager te liggen dan bij autochtonen. Terwijl bij de laatstgenoemde groep 78 procent van de mensen in 1991 meer dan $f 1900$ netto verdienden, was dat percentage voor de allochtonen ongeveer 55 . Werd alleen gekeken naar een netto-inkomen van meer dan $f 2700$, dan ontving 33 procent van de autochtonen ten minste dit inkomen. Bij de Antillianen was dit percentage 20, bij de Surinamers 11, bij de Marokkanen 5 en bij de Turken niet meer dan 2 . Het besteedbaar inkomen van allochtonen was ook geringer, ook omdat relatief veel meer mensen een uitkering ontvingen. Naast de werkloosheidsuitkering is dat de bijstand (voor Surinamers en Antillianen) en de WAO (voor Turken en Marokkanen) 62 . Omdat een uitkering beduidend lager is dan inkomen uit arbeid, geeft dit ook een neerwaarts effect. Veenman moet dan ook concluderen dat de inkomenspositie van de vier grootste allochtone groepen zich ongunstig onderscheidt van die van de autochtonen ${ }^{63}$.

\subsubsection{Wonen}

De allochtonen, die in deze beschouwing centraal staan, i.e. de Turken, Marokkanen, Surinamers en Antillianen, wonen niet regelmatig gespreid over het land. Integendeel, er is sprake van een duidelijke concentratie in de grote steden ${ }^{64}$. Allochtonen wonen vooral in de Randstad (12\% van de bevolking), daarbinnen vooral in de grote steden (27\% van de bevolking) en in die steden weer vooral in bepaalde wijken (soms meer dan $50 \%$ van de bevolking). Voor heel Nederland bedraagt het percentage allochtonen momenteel 7. De segregatie tussen allochtonen in de grote steden geconcentreerd in bepaalde wijken, en autochtonen, in andere wijken dan wel in andere plaatsen, maakt

57] Zie WRR (1989), op.cit.

58] Commissie allochtone leerlingen in het onderwijs (1992), Ceders in de tuin, deel 2. Noor een nieuwe opzet von het onderwijsbeleid, z.pl.

59] Vergelijk het terughoudende oordeel in Veenman, op. cit., blz. 63; en het veel positiever geformuleerde oordeel in J. Veenman en E. Martens, Op de toekomst gericht. Tweede generotie ollochtonen in Nederiond; 's-Gravenhage, VUGA, 1995, blz. 36.

${ }^{60}$ ] Zie G. Driessen en G. Van der Werf, Het functioneren van het voortgezet onderwijs. De positie van leerlingen in het eerste leerjoor, Nijmegen/Groningen, ITS/RION, 1992, blz. 92.

${ }^{61]}$ Eventuele inkomsten uit informele arbeid zijn niet in deze statistieken zijn terug te vinden.

62] Zie Veenman, op. cit., blz. 73.

63] Ibid., blz. 76.

${ }_{64}^{64}$ Mogelijkerwijs zou deze concentratie in de nabije toekomst kunnen afnemen, vanwege de plaatsingsprocedure van asielzoekers. Deze worden vooral buiten de grote steden gehuisvest. Op dit moment bestaat daar echter nog geen duidelijkheid over. Zie H.C. van der Wouden, De beklemde stad. Grootstedelijke problemen in demografisch en sociaaleconomisch perspectief. Rijswijk, SCP, 1996. 
de groep, en ook hun maatschappelijke problematiek, duidelijk zichtbaar. Overigens moet hierbij worden opgemerkt dat die segregatie ook binnen de minderheden zelf optreedt: Marokkanen en Turken wonen over het algemeen in andere wijken dan Surinamers en Antillianen en binnen wijken wonen de verschillende groepen weer in verschillende straten of huizenblokken ${ }^{65}$. Zelfs binnen één bevolkingsgroep bestaan er soms aanzienlijke verschillen, vooral vanwege verschillen in herkomst, bijvoorbeeld uit de steden dan wel van het platteland 66 .

De concentratiewijken in de grote steden, waar 20 procent of meer van de bevolking bestaat uit allochtonen, zijn zeker niet alleen de wijken met vooroorlogse woningen. Integendeel, allochtonen wonen relatief vaak in wijken met recente nieuwbouw. Daarin verschilt de Nederlandse situatie in positieve zin in aanzienlijke mate van het buitenland. Deze relatief gunstige huisvestingssituatie heeft het ontstaan van getto's en van maatschappelijke uitsluiting van deze groepen tot op heden in belangrijke mate verhinderd. Die situatie kon ontstaan door de omvangrijke inspanningen op het terrein van stadsvernieuwing in de oudere wijken in de grote steden, veelal de wijken waar veel allochtonen wonen. Daarnaast was er soms ook sprake van een samenloop van omstandigheden: De Bijlmer kwam gereed op een moment dat de toestroom van mensen uit Suriname vanwege de onafhankelijkheid uitzonderlijk groot was. De instroom van allochtonen in bepaalde wijken zorgde in een aantal gevallen voor een uitstroom van autochtonen, waardoor bijvoorbeeld de Bijlmer een andere populatie kreeg dan nog maar kort daarvoor was voorzien.

Over het algemeen bevatten wijken met een hoog percentage allochtonen veel huurwoningen, veel etagewoningen en relatief lage woonlasten. De huisvestingssituatie van allochtonen is de laatste jaren verbeterd, met directe consequenties voor de huisvestingskosten ${ }^{67}$. Daarnaast worden deze wijken gekenmerkt door een bovengemiddelde aanwezigheid van huishoudens zonder een betaalde baan, veel werklozen en andere uitkeringsgerechtigden en met een relatief laag inkomen ${ }^{68}$. Wordt onderscheid gemaakt naar de verschillende allochtone groepen, dan blijken ook nu weer de Surinamers en Antillianen/Arubanen er beter uit te komen dan de Turken en Marokkanen. Volgens Veenman hangt deze uitkomst samen met de eerder beschreven verschillen in opleidingsniveau en arbeidsparticipatie ${ }^{69}$. Dit sluit aan bij de bevindingen van Tesser, die stelt dat bij Surinamers en Antillianen wel en bij Turken en Marokkanen geen samenhang bestaat tussen sociaal-economische score en mate van concentratie per wijk. In alle gevallen zijn Turken en Marokkanen laag opgeleid, volgen de kinderen lagere opleidingen, is de arbeidsparticipatie van vrouwen gering, is de werkloosheid hoog en heeft het overgrote deel van deze mensen moeite met de Nederlandse taal en met de sociale oriëntatie op de Nederlandse samenleving. Bij Surinamers en Antillianen is de homogeniteit geringer: hoe geringer het aantal allochtonen in een wijk, des te hoger de sociaal-economische score 70 .

65] Zie P.T.M. Tesser en C.S. van Praag, Rapportage minderheden 1995. Concentratie en segregatie; Rijswijk, SCP, I995, blz. 69-8I.

66] Deze observatie is niet verrassend. Ook de instroom van mensen uit de verschillende provincies naar de grote steden in het begin van deze eeuw weerspiegelde zich in de woonlocatie. Zie het verschil tussen Rotterdam-Noord en Rotterdam-Zuid, en tussen de noord- en de zuidkant van de Westkruiskade in de wijk 'Het oude Westen'. Zie W. de Jong, Interetnische verhoudingen in een oude stodswijk; Delft, Eburon, 1986.

67] Zie Veenman, op. cit, blz. 114.

68] Zie Van der Wouden, op. cit., blz. 92-95.

69] Zie Veenman, op. cit, blz. 127-128.

70] Zie Tesser en Van Praag (1995), op.cit., blz. 451-452. 
De grote aandacht voor de huisvesting van allochtonen, voor de mate van concentratie, hangt nauw samen met verschillen in de visie op hun ontwikkelingsperspectief: is het gunstig of juist ongunstig dat allochtonen sterk geconcentreerd in bepaalde wijken van grotere steden leven? Op basis van vooral de ervaringen in de Verenigde Staten zijn hierover twee tegengestelde visies ontwikkeld 71. In de zogenaamde 'ecologische' benadering wordt een hoge concentratie van allochtonen niet als een slechte zaak gezien. De veronderstelling is dat steden zich voortdurend uitbreiden, waarbij nieuwkomers, waaronder immigranten uit andere landen, in eerste instantie in die wijken terecht komen die door de al aanwezige stedelijke bevolking als minder aantrekkelijk gezien worden. Vaak gaat het om oudere wijken, dicht tegen het stadscentrum. De hieruit voortvloeiende concentratie zorgt ervoor dat een sociaal milieu ontstaat waarin mensen opgevangen worden en de kans krijgen zich vertrouwd te maken met een nieuwe samenleving. De eerste migranten functioneren dan als kwartiermaker. Na verloop van tijd zouden zich binnen de groep van migranten dezelfde processen van differentiatie naar opleiding, arbeidsparticipatie, inkomen en huisvestingswensen gaan voordoen als bij de reeds aanwezige bevolking, wat tot een grotere spreiding over de rest van de stad zou leiden. Dit proces zou enige generaties kunnen beslaan.

Tegenover deze positieve ontwikkelingsschets staat de visie dat concentratiewijken niet tijdelijk zijn en juist tot segregatie in plaats van integratie leiden. Met name de ervaringen van de zwarte bevolking in de Verenigde Staten laten zien dat in een dergelijke situatie gettovorming kan optreden, met alle daarbij behorende kenmerken van lage scholing, hoge werkloosheid, druggebruik, verloedering en criminaliteit. Wie nog kansen had, verhuisde naar elders. Het gevolg was dat dergelijke concentratiewijken geen springplank vormden naar maatschappelijke verbetering, maar veel meer een armoedegetto schiepen, waaruit ontsnappen haast niet mogelijk was. Rath en Kloosterman zijn van mening dat het Amerikaanse zwarte getto zo ver afstaat van de Nederlandse realiteit dat het SCP deze tweede visie beter buiten beschouwing had kunnen laten ${ }^{72}$.

De vraag rijst welke beschrijving het meest overeenkomt met de Nederlandse ervaringen. Op het eerste gezicht lijkt dit inderdaad de ecologische benadering te zijn. Sinds de jaren zestig heeft Nederland te maken gekregen met een omvangrijke suburbanisatie vanuit de grote steden naar omringende gemeenten met meer ruimte en met een woningaanbod dat beter was afgestemd op de hogere inkomens en op de huishoudens met kinderen. Binnen en tussen steden ontstond een verhuisbeweging waarbij kansrijke autochtonen verhuisden naar die wijken dan wel die dorpen en gemeenten die beter aan hun woonwensen voldeden. Tegelijkertijd werden de opengevallen woningen in de stad ingenomen door allochtonen. De nieuwkomers vestigden zich in de minder aantrekkelijke wijken van de grote steden, met lagere woonlasten en meer etagebouw. Wanneer eenmaal het aantal allochtonen boven een bepaald percentage uitkwam, was dat weer aanleiding voor anderen om alsnog te besluiten te verhuizen. Het gevolg was dat bepaalde wijken in de stad momenteel voornamelijk door allochtonen bewoond worden. Gegeven de hoge bevolkingsgroei van de reeds aanwezigen en de indicaties voor voortgaande instroom vanuit het buitenland, zal het aantal allochtonen in de stad en daarmee ook het aantal wijken met een hoge concentratie nog toenemen.

Tesser en Van Praag stellen dat de concentratiewijken ernaar tenderen verzamelplaatsen te worden van kansarme, weinig op de Nederlandse samenleving georiënteerde allochtonen en relatief weinig verdienende, maar naar

$\left.{ }^{71}\right]$ Ibid., hfdst. 2.

72] Zie R. Kloosterman en J. Rath, 'Gangsta Paradise in Holland?'; Migrantenstudies, 1996, jrg. 12, nr. 2, blz. 94- 100. 
opleidingsniveau veel beter toegeruste autochtonen ${ }^{73}$. Dit zou kunnen duiden op het ontstaan van een situatie, waarin dergelijke wijken verworden tot getto's, met een werkloosheidscultuur die mensen afsluit van de samenleving en niet leidt tot maatschappelijke integratie. Tesser en Van Praag geven aan dat het vooral dankzij het huisvestingsbeleid nog niet zover is, maar dat er wel degelijk risicofactoren voor verslechtering aanwezig zijn ${ }^{74}$. Tesser noemt de hoge werkloosheid, de slechte schoolprestaties in deze wijken en de criminaliteitsontwikkeling als risicofactoren ${ }^{75}$. Daar waar allochtonen met een goede kennis van de Nederlandse taal en een op de Nederlandse samenleving gerichte oriëntatie in beginsel gelijke kansen hebben als anderen, is volgens Roelandt voor mensen die zich oriënteren op de eigen gemeenschap, die een slechte kennis van het Nederlands en een lage opleiding hebben, de kans op uitsluiting en op onderklassevorming aanwezig. Roelandt concludeert dat met name bij Turken en Marokkanen indicaties zijn voor een gedeeltelijke intergenerationele reproductie van sociale ongelijkheid ${ }^{76}$.

De hoge werkloosheid in de grote steden is terug te voeren op belangrijke ruimtelijke en economische veranderingsprocessen. De werkgelegenheid in de grote steden is de afgelopen jaren sterk teruggelopen. Nieuwe werkgelegenheid ontstond in de omliggende gebieden dan wel in verder weg liggende regio's. Wat in de grote stad aan werk is overgebleven, vereist over het algemeen een goede opleiding. Daarvoor komen eerder de beter opgeleide forenzen uit omringende gebieden in aanmerking dan de minder opgeleide allochtonen in de grote steden. Het gevolg is een hoge werkloosheid voor deze groep.

Sommige waarnemers zijn echter minder somber over de werkgelegenheidsontwikkeling. Hoe slecht de situatie ook is, toch zijn er ook tal van positieve signalen op te merken, in de formele maar vooral ook in de informele sfeer 77 . In sectoren als detailhandel en horeca, maar ook in de zorgsector zijn tal van nieuwe banen geschapen. Het etnisch ondernemerschap is de afgelopen jaren sterk gegroeid. Over activiteiten in de informele sfeer bestaat minder helderheid, maar ook hier is veel nieuwe werkgelegenheid geschapen ${ }^{78}$. De vooruitzichten zijn niet ongunstig, zeker ook in het licht van de in gang gezette deregulering die het voor allochtonen gemakkelijker maakt om een eigen zaak te beginnen. Daarnaast kunnen deze initiatieven een voorbeeldfunctie vormen voor anderen. Tegelijkertijd geldt ook hier dat een betere scholing ertoe bijdraagt dat verstandige beslissingen worden genomen; momenteel wordt maar al te vaak geïnvesteerd in zaken waarvoor te weinig perspectief bestaat.

De meeste analyses en beschouwingen over allochtonen in Nederland hebben vooral een statisch karakter. Er is veel onderzoek verricht naar ruimtelijke differentiaties in de verdeling van schaarse goederen als beroep, onderwijs en inkomen. De studies van het SCP vormen daar een goed voorbeeld van. Helaas is in die studies veel minder aandacht besteed aan een dynamische analyse van deze problematiek. Zo is tot op heden niet of nauwelijks onderzocht of mensen in de relatief slecht bedeelde wijken, als zij dit willen, kansen hebben om te migreren naar andere wijken of naar andere plaatsen, of als het ware opgesloten zijn op hun huidige woonplek. Indien allochtonen een stijging van hun maatschappelijke kansen, via meer opleiding en werk, kunnen

73] Zie P.T.M. Tesser en C.A. van Praag, 'Ruimtelijke segregatie en maatschappelijke integratie van allochtonen'; Migrantenstudies, 1996, jrg. 12, nr. 2, blz. 60-71.

74] Ibid., blz. 67 .

75] Zie Tesser en Van Praag (1995), op.cit., blz. 483-497.

76] Zie Th.J.A. Roelandt, Verscheidenheid in ongelijkheid. Een studie naor etnische stratificatie en onderklossevorming in de Nederlandse samenleving, Amsterdam, Thesis Publishers, 1994.

77 Zie Kloosterman, van der Leur en Rath, op. cit.

78] Zie Rath, op. cit. 
omzetten in een migratie naar andere wijken of steden, zou dit voor de maatschappelijke integratie van deze groep positief zijn; wanneer zij tegen hun zin in achterstandswijken zouden moeten blijven, zou het perspectief minder rooskleurig kunnen zijn ${ }^{79}$. Er valt weinig met zekerheid over te zeggen. Ook over de betekenis van kwartiermakers, over de voordelen van concentratiewijken voor het scheppen van formeel dan wel informeel werk, is de kennis nog zeer beperkt.

\subsubsection{De positie van allochtonen tot 2015}

Het beeld dat in deze paragraaf is geschetst van de situatie van de allochtonen in Nederland - laag opgeleid, vaak werkloos, met een relatief beperkt inkomen en een relatief slechte woonsituatie in specifieke grootstedelijke wijken - duidt op een structurele achterstandssituatie. Tegelijkertijd bleek hier toch ruimte voor differentiatie: niet alle allochtonen zitten in dezelfde situatie. Zo is de arbeidsmarktsituatie van de Surinamers en Antillianen/Arubanen relatief gunstig ten opzichte van de Turken en Marokkanen en is zij de laatste jaren ook duidelijk verbeterd. Verder bleek dat de arbeidsparticipatie van de allochtone groepen naar opleidingsniveau goed vergelijkbaar was met die van de autochtonen. Via verhoging van het opleidingsniveau zouden de allochtonen dus wel kansen hebben op meer maatschappelijke participatie.

Voor de toekomstige maatschappelijke participatie van allochtonen zijn met name de volgende vijf ontwikkelingen belangrijk: de demografische ontwikkeling, inclusief de immigratie, de huisvestingssituatie, vooral de mate van concentratie, het toekomstige opleidingsniveau, de economische ontwikkeling en de mate waarin deze groepen dan nog steeds onderaan de maatschappelijke ladder voorkomen.

In de bevolkingsprognoses van het CBS is de omvang van de netto-immigratie een van de meest bepalende factoren voor de bevolkingsontwikkeling in de nabije toekomst ${ }^{80}$. Dit ligt vooral aan de onzekerheid over de immigratie; bij de emigratie wordt slechts een lichte stijging verwacht. De schattingen voor de netto-immigratie in de periode tot 2015 lopen uiteen van jaarlijks 0 in CBSLaag tot een positief immigratiesaldo van jaarlijks 70.000 personen in CBSHoog. Het zal duidelijk zijn dat die uiteenlopende schattingen ook doorwerken in het aantal allochtonen dat in 2015 in Nederland op basis van deze bevolkingsprognose verwacht mag worden. Tabel 3.9 geeft een vooruitberekening tot aan 2015. Daaruit valt af te leiden dat het aantal allochtonen in $2015 \mathrm{zou}$ kunnen uitkomen op een omvang tussen 1,8 en 3,1 miljoen, ofwel tussen 11,3 en 17 procent van de totale bevolking. Ten opzichte van het aandeel in 1994, ongeveer 7,6 procent, is er in alle gevallen sprake van een toename, in het geval van de hoge bevolkingsprognose zelfs van een ruime verdubbeling ten opzichte van de situatie anno 1995.

79] Een indicatie dat dit laatste het geval zou kunnen zijn, ligt in de observatie dat allochtonen in de stedelijke gebieden in grotere mate dan de autochtonen ontevreden zijn over hun woning en over de sociale veiligheid. Zie F. Huls, 'Overlast woonomgeving treft vooral huurders'; INDEX, 1996, jrg 2., nr. 7, blz. 16-17.

${ }^{80}$ ] Zie De Beer (1996), op.cic. De hier door het CBS gebruikte definitie voor allochtonen komt grotendeels overeen met de in dit rapport gebruikte definitie. 


\begin{tabular}{lccc}
\hline & Laag & Midden & Hoog \\
\hline Allochtonen in 1994 & 1165 & 1165 & 1165 \\
Geboorte-overschot 1994-2014 & 459 & 459 & 459 \\
Vestigingsoverschot 1994-2014 & 158 & 748 & 1336 \\
Geboortes a.g.v. vestigingsoverschot & 28 & 85 & 152 \\
Allochtonen in 2015 & 1800 & 2457 & 3112 \\
Totale bevolking in 2015 & 15890 & 17064 & 18260 \\
Aandeel allochtonen in 2015 (perc.) & 11,3 & 14,4 & 17,0 \\
\hline
\end{tabular}

Bron: Eigen berekeningen WRR, gebaseerd op CBS-bevolkingsprognose 1994 en Sociaal Cultureel Rapport 1994, blz. 46.

Als er niets verandert in de huidige patronen van immigratie, en ook van binnenlandse migratie, die vooral wordt bepaald door werk, woning en groepscontacten ${ }^{81}$, dan zullen de gevolgen van deze ontwikkeling weliswaar in heel Nederland merkbaar zijn, maar toch vooral in de Randstad, nog sterker in de vier grote steden en daarbinnen bovenal in bepaalde wijken. Tabel 3.10 geeft een indicatie van de verwachte regionale verdeling van allochtonen in Nederland volgens de drie bevolkingsprognoses in 2015 82. Ter vergelijking zijn ook de uitkomsten voor 1994 weergegeven. In dat jaar bedroeg het aantal allochtonen 1,165 miljoen, waarvan 70 procent woonachtig was in de Randstad en $\mathbf{4 5}$ procent in de vier grote steden ${ }^{83}$. Van de bevolking buiten de Randstad is 4,2 procent allochtoon, in de Randstad 11,9 procent en in de grote steden bedraagt dit percentage 26,3 . Ook binnen de grote steden is de spreiding van de allochtonen niet gelijkmatig ${ }^{84}$.

Tabel 3.10 Aandeel allochtonen in de totale bevolking, naar regio, $1994 \mathrm{en}$ 2015

\begin{tabular}{lcccc}
\hline & 1994 & CBS-Laag & $\begin{array}{c}\text { 2015 } \\
\text { CBS-Midden }\end{array}$ & CBS-Hoog \\
\hline Nederland & 7,6 & 11,3 & 14,4 & 17,0 \\
Niet-Randstad & 4,2 & 6,3 & 7,9 & 9,3 \\
Randstad & 11,9 & 17,7 & 22,5 & 26,7 \\
Vier grote steden & 26,3 & 38,5 & 49,5 & 59,0 \\
\hline
\end{tabular}

Toelichting:

Niet-Randstad: Groningen, Friesland, Drenthe, Overijssel, Flevoland, Gelderland, Zeeland, Noord-Brabant en Limburg

Randstad: Utrecht, Noord- en Zuid-Holland

Vier grote steden: Amsterdam, Rotterdam, 's-Gravenhage en Utrecht

Bron: Eigen berekeningen WRR.

81] Onduidelijk is hoe de regionale spreiding zal worden van asielzoekers. Hun geforceerde regionale spreiding is momenteel veel groter, maar onbekend is of na verloop van tijd toch niet alsnog een heroriëntatie op de grote steden zal plaatsvinden.

82] Zie Ministerie van Volkshuisvesting, Ruimtelijke Ordening en Milieubeheer, Regionole bevolkingsprognose 1994; 's-Gravenhage, 1994.

83] Zie Centraal Bureau voor de Statistiek, 'Bevolking naar geboorteland en geboorteland van ouders, per provincie en in de vier grote gemeenten, I januari 1992'; Maandstotistiek van de Bevolking, 1992, jrg. 42, nr. 3, blz. 34-47; en Centraal Bureau voor de Statistiek, 'Bevolkingsontwikkeling vier grote gemeenten vooral bepaald door buitenlandse migratie'; Maandstatistiek van de Bevolking, 1994, jrg. 44, nr. II, blz. 22-26.

84] Zie Tesser en Van Praag (1995), op.cit,, hoofdstuk 2. 
Volgens de meest verregaande variant, CBS-Hoog, loopt het percentage allochtonen in 2015 voor heel Nederland op tot 17 . Voor de provincies buiten de Randstad zou het aandeel dan uitkomen op 9,3 procent, voor de Randstad op 26,7 procent en voor de vier grote steden op 59 procent 85 . Vooralsnog ziet het er niet naar uit dat de netto-immigratie zich zal voltrekken overeenkomstig deze variant ${ }^{86}$, maar zelfs in het CBS-Laag scenario zal in 2015 naar verwachting bijna 40 procent van de bevolking van de vier grote steden uit allochtonen bestaan. Gegeven de nu al bestaande verdeling binnen de steden, houdt dat in dat nog meer wijken nog grotere concentraties allochtonen zullen tellen. Nogmaals, deze berekeningen zijn gebaseerd op trends zoals deze de afgelopen jaren waarneembaar waren. Eerder is al betoogd dat op dit moment geen inzicht bestaat in de mogelijke samenhang tussen maatschappelijke participatie en migratie vanuit achterstandswijken naar andere wijken dan wel naar omringende gemeenten. Als die samenhang wel bestaat en als allochtonen er in slagen hun positie te verbeteren, ligt het voor de hand dat bovengenoemde percentages anders zullen uitvallen.

Ongeacht het al dan niet optreden van suburbanisatie bij allochtonen, is een oordeel over deze situatie mede afhankelijk van de omvang van de immigratie. Is de immigratie gering, en wordt de bevolkingsgroei vooral veroorzaakt door geboortes, dan is de situatie vanuit het oogpunt van maatschappelijke participatie positiever in te schatten dan in de situatie dat vooral immigratie voor die toename verantwoordelijk is. De maatschappelijke integratie van allochtonen in de Nederlandse samenleving blijkt vooral moeilijk te zijn voor diegenen die in het buitenland geboren zijn, de Nederlandse taal niet geleerd hebben en die onvoldoende opleiding hebben voor een entree op de arbeidsmarkt 87 . Voor diegenen die in Nederland geboren zijn, is de situatie weliswaar niet zonder problemen, maar over het algemeen verloopt de maatschappelijke integratie dankzij het onderwijs en de kennis van de Nederlandse taal toch eenvoudiger. Naarmate de immigratiestroom geringer is, zal het aandeel van de hier geborenen sneller toenemen, en daarmee de kans op integratie in de Nederlandse samenleving. Op basis van analyses van Butzelaar valt op te maken dat voor de hier onderscheiden groep van allochtonen op dit moment ongeveer 27 procent in Nederland geboren is of tot de tweede generatie kan worden gerekend ${ }^{88}$. Op basis van eigen berekeningen en uitgaande van de CBS-Laag variant, zou dit percentage in 2015 uitkomen op 41. In de CBSHoog variant zou het aandeel van de hier-geborenen beduidend lager uitkomen, namelijk op 27 procent. In dat geval mag verwacht worden dat de maatschappelijke integratie van deze groepen in de Nederlandse samenleving in 2015 minder ver zal zijn voortgeschreden.

Ook in 2015 zal de meerderheid van de allochtonen nog tot de eerste generatie behoren. Hoe waardevol alle onderwijsinspanningen aan allochtone kinderen ook zijn, daarmee wordt toch slechts een deel van deze bevolkingsgroep bereikt. Ook dan zal, net als nu, een meerderheid niet hier naar school zijn geweest, met alle aanpassingsproblemen vandien. Dit alleen al is voldoende

85] Van de vier grote steden wordt voor Amsterdam het hoogste percentage verwacht, namelijk 66,7 procent van de totale bevolking.

86] Zie Ph. Muus, 'Migratie naar Nederland daalt snel'; Stautscourant, 13-6-1996, blz. 4. Recente berichten maken weliswaar gewag van een hernieuwde toename van immigratie (zie bijv. B. Bommels, 'Nederland 'verkleurt' sneller'; Elsevier, 19-10-1996), maar ook dan komt de totale netto-immigratie (30.000 personen) voor 1996 lager uit dan verondersteld wordt in het CBS-Midden scenario (35.000 personen).

घ7 Die laatste toevoeging is niet onbelangrijk. In het begin van de paragraaf over allochtonen is duidelijk gemaakt dat er tal van allochtonen in Nederland wonen, die aan de eerste twee voorwaarden voldoen, die zich afzijdig houden van de Nederlandse samenleving en desondanks niet als gesegmenteerd gezien worden.

88] Zie E. Butzelaar, Prognose eerste en tweede generotie allochtonen; Doctoraal-scriptie, Universiteit van Amsterdam, 1995. 
reden om de recente koerswijziging in het allochtonenbeleid, namelijk streven naar een betere inburgering van alle hier aanwezige allochtonen, toe te juichen. Door een grotere maatschappelijke weerbaarheid, door een betere kennis van de Nederlandse taal en samenleving, is de kans op maatschappelijke integratie, via de arbeidsmarkt, de woningmarkt, de huwelijksmarkt, ook groter. Van deze factoren is de arbeidsmarkt waarschijnlijk de belangrijkste. Wanneer men erin zou slagen de arbeidsparticipatie van de eerste generatie allochtonen te verhogen, bereikt men niet alleen dat deze mensen een hoger inkomen krijgen, maar ook dat zij daardoor meer kansen hebben op betere huisvesting en daarmee weer op betere scholingsmogelijkheden voor de kinderen. In dat perspectief wordt een verbetering van de arbeidsparticipatie gezien als de aanjager van de dynamiserende stadsontwikkeling, waarbij mensen aanvankelijk in een concentratiewijk wonen maar na verloop van tijd voldoende mogelijkheden ontwikkelen om hun eigen positie te verbeteren. Gegeven de momenteel verwachte ontwikkeling van de concentratiewijken - allochtonen vormen ten minste 40\% van de bevolking van de grote steden -, wordt daarmee de kans groter dat deze concentratiewijken zullen veranderen in armoedegetto's. Hoe hoopgevend de perspectieven voor de arbeidsmarkt ook zijn, zoals in hoofdstuk 2 beschreven, de positie van de lagergeschoolden en dus ook van de meeste allochtonen zal ceteris paribus ook in de overzienbare toekomst problematisch blijven. Dit impliceert dat de problemen niet zullen worden opgelost als men de volle nadruk legt op een verbetering van individuele kwalificaties. Ook aan de aanbodkant van de arbeidsmarkt zullen structurele veranderingen moeten worden doorgevoerd. Gebeurt dit niet en wordt de bestaande situatie gehandhaafd, met feitelijk een blokkade voor laaggeschoolde werkgelegenheid, dan zijn de vooruitzichten op voldoende maatschappelijke participatie ook voor deze groep laaggeschoolden weinig hoopvol. Vandaar dat aan het slot van dit hoofdstuk juist op dit vraagstuk zal worden teruggekomen.

\subsection{Ouderen}

\subsubsection{Inleiding}

Toekomstige ontwikkelingen zijn doorgaans onzeker, maar voor demografische ontwikkelingen geldt dit in mindere mate. De ouderen van na 2015 zijn er immers al, zij vormen de generaties die nu 40 jaar en ouder zijn. Zoals in tal van publicaties al is aangegeven, is één ding duidelijk: er zullen veel meer ouderen komen en, nauw hiermee verbonden, zonder beleidscorrecties op tal van terreinen, ook veel meer problemen ${ }^{89}$. Terwijl momenteel ruim 13 procent van de bevolking ouder is dan 65 jaar, stijgt dat percentage tot ruim 14 in 2005 en tot bijna 17 in $2015{ }^{90}$. In die jaren zal de naoorlogse geboortegolf tot de rijen der 65-plussers toetreden. Het aandeel van de ouderen in de totale bevolking zal dan nog sneller gaan toenemen, tot ongeveer 23 procent in 2035 .

De groei van het aantal ouderen is vooral problematisch genoemd in verband met de financiering van de pensioenen. In dit rapport is de invalshoek een andere, namelijk de vraag of mensen in deze groep door hun bijzondere situatie - leeftijd, gepensioneerd zijn, gezondheid, huisvesting en inkomen - voldoende dan wel onvoldoende mogelijkheden hebben tot maatschappelijke participatie. Waar in dit rapport de nadruk wordt gelegd op meer maatschappelijke participatie via arbeid en op een grotere dynamiek, daar is juist kenmerkend voor de onderhavige groep dat ze niet meer op de arbeids-

89] Zie bijvoorbeeld WRR, Ouderen voor ouderen; Demogrofische ontwikkelingen en beleid; Rapporten aan de Regering $\mathrm{nr}$. 43 , 's-Gravenhage, Sdu Uitgeverij, 1993; en R.M.A. Jansweijer, Gouden bergen, diepe dalen; De inkomensgevolgen van een betoolbore oudedagsvoorziening, WRR, Voorstudies en achtergronden nr. 92, 's-Gravenhage, Sdu Uitgeverij, 1996.

90] Bij de vrouwen liggen de percentages hoger en bij mannen lager. 
markt actief is en dat de dynamiek beperkt is. Hoe problematisch is dit? Achtereenvolgens zal de situatie van de ouderen aan de hand van de verschillende thema's worden verkend.

\subsubsection{Arbeidsmarkt}

Het is wellicht vreemd dat ook in deze paragraaf begonnen wordt met de arbeidsmarkt. Over het algemeen werken mensen na hun vijfenzestigste levensjaar niet meer. Dit geldt met name voor werknemers; het reguliere arbeidscontract loopt dan af. Het is niet verboden een nieuwe overeenkomst af te sluiten, maar de animo daarvoor is vooralsnog beperkt, bij werknemers èn werkgevers. Bij zelfstandigen komt werken na het vijfenzestigste levensjaar vaker voor. Er zijn dus ouderen die na hun vijfenzestigste nog werken, maar hun aantal is beperkt. Een vergelijking met andere OESO-landen laat zien dat de arbeidsparticipatie in deze leeftijdsgroep in Nederland al in 1986 uiterst gering was. Waar in dat jaar percentages konden worden waargenomen van 3 voor mannen en 1 voor vrouwen ${ }^{91}$, lag in 1990 in 11 landen het percentage bij de mannen en in 4 landen bij de vrouwen boven de 8 procent ${ }^{92}$. Uitschieter was Japan, maar ook zulke verschillende landen als de Verenigde Staten, Noorwegen en Portugal lieten een relatief hoge arbeidsparticipatie van ouderen zien.

Dit roept de vraag op naar het waarom van de lage arbeidsparticipatie in Nederland. Wiggers stelt dat ouderen in dit land niet meer hoeven, mogen, willen en kunnen werken ${ }^{93}$. Ook De Kemp geeft aan dat een complex van factoren hiervoor verantwoordelijk is, uiteenlopend van macrofactoren - instituties, demografische en economische ontwikkeling en sociaal-culturele visies en organisatiespecifieke aspecten tot individuele omstandigheden. Bij dat laatste kan men denken aan de kwaliteit van de arbeid, sociale en medische factoren, financiële overwegingen "en sociaal-demografische aspecten ${ }^{94}$. Wanneer de argumentatie beperkt wordt tot economische argumenten, leiden het achterblijven van het aanbod van banen, de divergentie tussen de vraag naar hooggeschoolde werknemers en de relatief lage scholing van ouderen, hun lagere productiviteit en hun relatief hoge beloning ertoe dat de arbeidsmarkt voor ouderen eerder push- dan pull-factoren kent. Wanneer dan ook nog allerlei regelingen bestaan - zoals WAO en VUT - die het vertrek van de arbeidsmarkt ruim voor het bereiken van het vijfenzestigste levensjaar al zeer aantrekkelijk maken, mag de lage arbeidsparticipatie geen verwondering meer wekken. Niet voor niets is ook de arbeidsparticipatie van de leeftijdsgroep 55 tot 65 jaar met net 40 procent in internationaal perspectief tamelijk laag. Overigens is die lage arbeidsparticipatie pas van recente datum. Zo lag in 1972 de arbeidsparticipatie van de groep tussen 55 en 65 jaar nog op bijna 80 procent en die van de 65-plussers nog altijd op 10 procent.

Zoals de arbeidsparticipatie van ouderen sindsdien dramatisch is gedaald, zo zou niet bij voorbaat een terugkeer naar de eerdere situatie uitgesloten moeten worden. De noodzaak van een dergelijke correctie neemt naar verwachting toe. De discrepantie tussen vraag en aanbod op de arbeidsmarkt lijkt al in het begin van de volgende eeuw af te gaan nemen. Natuurlijk, opnieuw geldt dat de markt voor lagergeschoolden, voor de minder productieven langzamer geruimd zal worden dan voor de anderen. Voor oudere werknemers geldt echter ook dat zij vaak meer ervaring hebben, hetgeen voor werkgevers aantrekkelijk kan zijn. Daarnaast geldt dat geleidelijk aan de eerste naoor-

9'] Latere gegevens zijn niet beschikbaar.

92] Zie A.A.M. de Kemp, Ouderen tussen pensioen en bijstand; Rijswijk, SCP, 1992, blz. 98.

93] Zie J.A. Wiggers, Ouderen en arbeidsmarkt; Rijswijk, Ministerie van WVC, 1990.

94] Zie De Kemp, op. cit., speciaal hfdst. 4. 
logse generaties, die veel beter zijn opgeleid, tot de ouderen gaan behoren. Dankzij die betere scholing zijn hun arbeidsmarktkansen gunstiger. Daarenboven zijn deze nieuwe groepen ouderen gemiddeld genomen gezonder en daardoor ook productiever. De conclusie kan luiden dat het aanbod van arbeid voor deze groep weer zou kunnen gaan toenemen. Aan de andere kant zijn of worden belangrijke veranderingen in de sociale zekerheid doorgevoerd - met name in de WAO en VUT - waardoor de uitstroom zal gaan afnemen. Gevoegd bij de in gang gezette maatschappelijke discussie over pensioenkosten, mag verwacht worden dat ook in de sociaal-culturele sfeer bij ouderen (en jongeren) een andere houding ten opzichte van arbeid zou kunnen ontstaan. Zelfs moet het niet uitgesloten worden geacht dat binnen afzienbare tijd ook arbeid door gepensioneerden weer in een ander daglicht zal worden geplaatst ${ }^{95}$.

\subsubsection{Inkomen}

Een volwaardige maatschappelijke participatie van ouderen hangt, aldus ook de nota Ouderen in tel, in belangrijke mate af van een toereikend inkomen ${ }^{96}$. Juist ook omdat ouderen niet of nauwelijks kans hebben om via arbeid een extra inkomen te verwerven, hangt hun inkomenspositie in belangrijke mate af van eerder genomen persoonlijke beslissingen over opleiding, werk, en pensioenopbouw. Tegelijkertijd wordt de huidige inkomenspositie ook beïnvloed door tal van macro-economische beslissingen, uiteenlopend van het al dan niet handhaven van de koppeling tot de prijsontwikkeling in het algemeen en die voor huisvesting en gezondheidszorg in het bijzonder.

De inkomensontwikkeling van ouderen laat een verbetering van de relatieve positie zien in de jaren zeventig en een relatieve verslechtering daarna ${ }^{97}$. Het inkomen van ouderen bestaat uit de AOW-uitkering, eventueel aangevuld met bedrijfspensioenen, inkomen uit vermogen of inkomenssubsidies zoals de individuele huursubsidie. Aanvullende pensioenen en inkomen uit vermogen komen iets vaker terecht bij echtparen en mannen dan bij vrouwen. Verder blijkt het inkomen van zelfstandig-wonenden belangrijk hoger uit te komen dan van tehuisbewoners ${ }^{98}$. De indruk bestaat dat er een niet onaanzienlijke groep ouderen is, vooral alleenstaande vrouwen, die geen ander inkomen hebben dan een AOW-uitkering. Zo alleenstaande vrouwen al in aanmerking komen voor een aanvullend pensioen, dan is hun uitkering beduidend lager. Timmermans laat zien dat ongeveer 20 procent van de alleenstaande 65-plussers, voor het merendeel vrouwen, en 8 procent van de echtparen een besteedbaar inkomen hebben tot 105 procent van het sociaal minimum. Die kans neemt toe naarmate men ouder wordt ${ }^{99}$.

Recent heeft het CBS gegevens gepubliceerd over de betekenis van aanvullende inkomsten voor AOW-ers ${ }^{100}$. De gegevens hebben betrekking op 1994. Daaruit komt naar voren dat de meeste huishoudens in deze groep over een aanvullend inkomen beschikken. Acht van de tien huishoudens hebben een aanvullend pensioen, ruim de helft heeft inkomen uit vermogen en ongeveer een kwart van de ouderen ontvangt individuele huursubsidie. Die aanvullingen zijn niet onaanzienlijk. Gemiddeld genomen is het aanvullend inkomen

95] Gezien de negatieve reacties op voorstellen in deze zin van de WD en VNO/NCW is de publieke opinie op dit moment zeker nog niet zo ver.

96] Zie Ministerie van Welzijn, Volksgezondheid en Cultuur, Ouderen in Tel, Beeld en beleid rond ouderen 1990-1994; Tweede Kamer 1990/1991, 21814, nrs. 1-2.

97 Zie J.A.M. Timmermans, Rapportoge ouderen 1993; Riịswijk, SCP, 1993, blz. 15 en 16.

98] Ibid., blz. 18-20.

99] Ibid., blz. 21.

${ }_{100}$ Zie W. Bos. 'Inkomen van AOW-ers, 1994'; SociootEconomische Maandstatistiek, 1996, vol. 13, nr. 8, blz. 20-23. 
gelijk aan de AOW, terwijl bij echtparen de toename nog groter is. Wordt het besteedbaar inkomen gestandaardiseerd naar huishoudomvang, dan komt men op jaarbasis gemiddeld 1.800 gulden lager uit dan de overige huishoudens. Bij een verdeling van de totale huishoudenspopulatie in tien naar omvang gelijke groepen, komen de 65-plussers op basis van het gestandaardiseerd inkomen vooral in het tweede, derde en vierde deciel voor.

Op een totaal van 1,32 miljoen huishoudens van ouderen, waren er 41.000 zonder enige aanvullend inkomen en in totaal 134 duizend (ongeveer $10 \%$ van de totale populatie) met een aanvullend inkomen tot maximaal 200 gulden per maand. Jonge ouderen hebben een hoger besteedbaar inkomen dan senioren. Alleenstaande vrouwen komen relatief vaak in aanmerking voor individuele huursubsidie.

Het besteedbaar inkomen bedroeg per huishouden in 199436.400 gulden. Sinds 1990 is het nominale bedrag jaarlijks gemiddeld met 2 procent toegenomen, maar omdat jaarlijks de prijzen met 2,5 procent stegen, betekende dit reëel een jaarlijkse daling met een half procent ${ }^{101}$. Alleenstaanden komen gemiddeld uit op 26.600 gulden ( $73 \%$ ), echtparen (met beiden een AOW) hebben een besteedbaar inkomen van 40.600 gulden (112\%).

Twee probleemgroepen springen eruit, namelijk AOW-ers in bejaardenhuizen en verzorgingstehuizen, en alleenstaande vrouwen. De AOW-ers in een institutioneel huishouden hebben een jaarlijks besteedbaar inkomen van 20.600 gulden, diegenen zonder aanvullend pensioen zelfs maar 16.800 gulden (46\% van het gemiddelde). Het gaat in totaal om 137.000 mensen, ruim 10 procent van het totaal. Alleenstaande vrouwen hebben een besteedbaar inkomen van 25.900 gulden, diegenen zonder aanvullend pensioen 21.900 gulden ${ }^{102}$. Dit is nauwelijks 60 procent van het gemiddelde. Gegeven de zwaarte van de vaste lasten ${ }^{103}$, die ook blijkt uit het omvangrijke beroep op de individuele huursubsidie, is hier sprake van een omvangrijk en structureel probleem. Het gaat om 144.000 vrouwen, 11 procent van de 65-plussers. Deze groep beslaat 50 procent van alle huishoudens zonder aanvullend pensioen. Hun aantal neemt sterk toe met de leeftijd.

Wanneer verondersteld wordt dat de AOW zich tot 2015 min of meer welvaartsvast zal ontwikkelen, zijn de inkomensvooruitzichten voor ouderen op het eerste oog niet ongunstig. Zo neemt het aantal 65-plussers zonder aanvullend pensioen snel af. Van de groep ouder dan 80 jaar heeft ruim 28 procent geen aanvullend pensioen, van de groep tussen 65 en 69 jaar is dat percentage nog maar 14 . Bij de alleenstaande vrouwen zijn die percentages 31 respectievelijk 20. De verklaring voor deze afname moet gezocht worden in de sterke toename van het aantal mensen met een aanvullend bedrijfspensioen, alsmede de sterke groei van het aantal werkende vrouwen. De gevolgen van deze laatste ontwikkeling zijn nu nog maar beperkt merkbaar, maar op de langere termijn zal dit de inkomenspositie van oudere vrouwen in belangrijke mate positief gaan beïnvloeden. Beide ontwikkelingen dragen ertoe bij dat naar verwachting steeds minder 65-plussers in de toekomst zonder aanvullend pensioen en dus met een relatief laag inkomen moeten zien rond te komen.

101] Zie L. Trimp, 'Tien jaar koopkrachtveranderingen: 1984-1994'; Sociaal Economische Maandstatistiek, 1996, vol. 13, nr. I, blz. 21-25.

102] Overigens is het inkomen van alleenstaande mannen zonder aanvullend pensioen nauwelijks hoger. Wel is hun aantal (28.000) veel geringer dan van de vrouwelijke alleenstaanden.

103] In 1990 gaven 65-plussers gemiddeld 37 procent van hun inkomen uit aan woonlasten (huur, verwarming, verlichting, enz.), alleenstaanden zelfs 42 procent. Zie Timmermans, op. cit., blz. 23. 
De grootste onzekerheid betreft echter precies de basis van de inkomens voor ouderen, namelijk de AOW ${ }^{104}$. Voor de hoogte van de AOW is het van groot belang of men ernaar streeft bij het sociaal minimum de gemiddelde prijs- dan wel loonontwikkeling te volgen èn of de koppeling tussen sociaal minimum en AOW-uitkering gehandhaafd blijft. Volgt men de prijsontwikkeling en blijft de koppeling gehandhaafd, dan zal de inkomenstoename veel geringer zijn dan in het geval men kiest voor de welvaartsvaste variant. Vooral voor mensen die slechts een gedeeltelijk aanvullend bedrijfspensioen hebben weten op te bouwen, doordat ze geen $\mathbf{4 0}$ dienstjaren hebben opgebouwd dan wel in deeltijd hebben gewerkt, impliceert de keuze voor een waardevaste AOW-ontwikkeling een veel lager inkomen dan wanneer men voor een welvaartsvaste AOW zou hebben geopteerd. Verder bestaat er onzekerheid over de vraag hoe de aanvullende bedrijfspensioenen er in de toekomst uit zullen zien. In de discussies over een mogelijk drieslagstelsel - AOW, aanvullend bedrijfspensioen en individuele regeling - krijgt het derde onderdeel steeds meer aandacht. Dit zou kunnen betekenen dat het aanvullend bedrijfspensioen wellicht minder inkomen zou gaan opleveren dan op dit moment het geval is. Weliswaar lijken in de nabije toekomst meer 65-plussers over een extra inkomen naast hun AOW te beschikken, maar duidelijk zal zijn dat over de hoogte van het daarmee te bereiken inkomen veel onzekerheid bestaat.

Ongeacht de te verwachten ontwikkeling van de hoogte van de AOW, is het op basis van de huidige situatie gewenst in te grijpen in de inkomensontwikkeling van twee groepen, namelijk van AOW-ers in een institutioneel huishouden en van alleenstaanden zonder aanvullend pensioen. Is men werkelijk de opvatting toegedaan dat de maatschappelijke participatie van ouderen afhankelijk is van de hoogte van het besteedbaar inkomen, dan is het dringend gewenst dat op enigerlei wijze de inkomenspositie van deze personen wordt verbeterd. Dit kan via aanpassingen in de hoogte van de AOW, maar ook kan men denken aan andere regelingen, bijvoorbeeld de individuele huursubsidie.

\subsubsection{Wonen 105}

$\mathrm{Bij}$ de bespreking van de inkomenspositie van ouderen is al aangegeven dat ouderen te maken hebben met relatief hoge woonlasten, gegeven het besteedbaar inkomen. Dit geldt vooral voor huurders. Hoe ouder men wordt, hoe hoger de woonkosten. Eigenaren van een eigen huis hebben juist lagere kosten, die ook nog eens afnemen met de leeftijd. Ouderen zijn over het algemeen tevreden over de woning die zij hebben. Als ze verhuizen, gebeurt dit vooral vanwege gezondheids- of leeftijdsredenen. De afgelopen jaren is het aantal aangepaste woningen weliswaar toegenomen, maar nog altijd blijft het aanbod achter bij de vraag. Juist voor de senioren, diegenen boven de 80 , is de behoefte aan dit soort woningen groot.

\subsubsection{Maatschappelijke participatie}

In een samenleving waarin betaalde arbeid voor velen de sleutel tot maatschappelijke participatie is, stelt zich de vraag naar de maatschappelijke participatie van diegenen die vanwege hun leeftijd niet meer aan het arbeidsproces mogen (en vaak ook niet meer kunnen) deelnemen. Voor deze groep geldt dat de maatschappelijke participatie afhankelijk is van geld, tijd, gezondheid en mobiliteit. Hiervoor is aangegeven dat de situatie voor de ouderen wat betreft het besteedbaar inkomen en de huisvesting grosso modo als positief

104] Zje WRR (1993), op. cit; en Jansweijer, op. cit.

105] Deze paragraaf is gebaseerd op Timmermans, op. cit., blz. 32-43. 
beoordeeld kan worden, met uitzondering van die groepen die alleen van een AOW-uitkering moeten leven. Dit houdt in dat voor de meeste ouderen maatschappelijke participatie in principe mogelijk is.

In de periode 1974-1991 is de gezondheidstoestand van de ouderen tamelijk stabiel geweest, op basis van het eigen oordeel van betrokkenen. Ook als gekeken wordt naar het gebruik van medische dienstverlening, is de situatie tussen 1974 en 1991 nauwelijks veranderd. Wordt in de populatie ouderen een onderscheid gemaakt naar zelfstandig wonende ouderen en bewoners van bejaardenoorden, dan blijkt de eerste groep beduidend gezonder uit de bus te komen. Dit hangt ook samen met de leeftijd, en met de daarmee samenhangende grotere kans om alleenstaand te worden. Is men eenmaal de 75 gepasseerd, dan loopt het aantal klachten snel op ${ }^{106}$ en is men veel meer afhankelijk van enigerlei vorm van hulp. Eerder is al aangegeven dat deze groep snel in omvang toeneemt.

Gebrek aan tijd lijkt voor ouderen geen probleem. Men werkt niet meer, men heeft meestal geen kinderen meer te verzorgen: er is ruimte voor andere activiteiten. Die toename valt echter slechts gedeeltelijk toe aan vrije tijd. Ouderen blijken namelijk meer tijd aan persoonlijke verzorging en overige verplichtingen te besteden, wat mede samenhangt met de achteruitgang in gezondheid. Dit geldt vooral voor de senioren. Daarnaast zorgt de traditionele rolverdeling er voor dat vrouwen ook in deze levensfase minder vrije tijd hebben dan mannen. Ouderen kijken meer televisie, lezen meer en besteden meer tijd aan hobby's dan jongeren. De toename in vrije tijd heeft zich vertaald in een grotere tijdsbesteding van traditionele activiteiten, niet of nauwelijks in nieuwe tijdsbestedingen. Bij deelname aan recreatieve en culturele voorzieningen elders blijken de mate van validiteit, het opleidingsniveau, de urbanisatiegraad en de leeftijd van invloed te zijn. Het inkomen blijkt geen significante invloed uit te oefenen ${ }^{107}$.

Om aan externe activiteiten te kunnen deelnemen, moeten mensen mobiel zijn. De mogelijkheden hiervoor lijken te zijn toegenomen, zeker wat betreft het particulier vervoer ${ }^{108}$. Het autobezit en het autogebruik van ouderen loopt nog steeds op, ook doordat bij de vrouwen sprake is van een duidelijk inhaaleffect. Tussen 1978 en 1994 is het aantal rijbewijsbezitters ouder dan 65 jaar met 150 procent toegenomen. Bij de vrouwen bedroeg die toename zelfs 414 procent. Terwijl in 1978 slechts ruim 5 procent van de vrouwen een rijbewijs had, bedraagt dit percentage nu 30. Gezien de percentages bij de vrouwen boven de 50 jaar zal dit snel verder oplopen. Het aantal vrouwen dat een auto bezit, is nog laag (16\%), maar ook hier zijn er voldoende aanwijzingen voor een snelle groei. De vervoersconsumptie van ouderen bevindt zich in een stijgende lijn, met een toenemend aandeel voor de auto en een licht dalend aandeel voor het openbaar vervoer. Wordt onderscheiden naar mannen en vrouwen, dan valt op dat mannen per dag vaker en verder reizen, en dat hun vervoersconsumptie wel en die van vrouwen nauwelijks is toegenomen. Verder valt op dat oudere vrouwen relatief vaker gebruik maken van het openbaar vervoer. Eventuele veranderingen in de prijs en de kwaliteit van het openbaar vervoer - lijnennet, frequentie, veiligheid - kunnen derhalve voor oudere vrouwen van meer belang zijn dan voor mannen.

106] Zo loopt het aantal klachten over functiestoornissen bij mensen boven de 75 jaar snel op. Zie Timmermans, op. cit., blz. 46.

107] Zie Sociaal-Cultureel Planbureau (1996), op. cit, hfdst. 8.

108] Zie Centraal Bureau voor de Statistiek, De mobiliteit van de Nederlandse bevolking 1995; Voorburg/Heerlen, 1996, en eerdere edities van deze statistiek. 
De laatste jaren zijn 'ouderen' in toenemende mate onderwerp van maatschappelijke discussie geworden. In deze discussie sprongen twee zaken er uit: de inkomenspositie van ouderen, meestal vrouwen, die moesten zien rond te komen met alleen een AOW-uitkering zonder aanvullend pensioen, en de financiële gevolgen op lange termijn van de demografische ontwikkeling met een snel oplopende 'grijze druk'. De aandacht concentreerde zich hierbij vooral op de betaalbaarheid van de AOW. De onzekerheid daarover onder ouderen weerspiegelde zich in de doorbraak van ouderenpartijen bij de verkiezingen voor de Tweede Kamer in mei 1994.

Het beeld dat deze ouderenpartijen oproepen, is dat van bezorgdheid en ongerustheid. Naar de mening van de Raad behoeft dit betrekkelijk negatieve beeld nuancering vanuit het perspectief van maatschappelijke participatie. Natuurlijk zijn er onzekerheden, maar tegelijk is in het voorgaande duidelijk gemaakt dat de vooruitzichten voor de maatschappelijke participatie van ouderen in de periode tot 2015 tamelijk positief zijn. Deze inschatting is vooral terug te voeren op de constatering dat de samenstelling van de groep ouderen, gelet op het aspect van inkomensverwerving, drastisch zal veranderen. De komende jaren is een instroom te verwachten van mensen, die veel beter geschoold zijn en die over het algemeen een gunstiger arbeidsmarktcarrière hebben kunnen volgen dan diegenen die de afgelopen jaren de grens van 65 jaar zijn gepasseerd ${ }^{109}$. Voor deze personen gold dat zij hebben moeten werken in een tijd van economische crisis (jaren dertig) en van de Tweede Wereldoorlog, dan wel dat zij bij de wederopbouw waren ingeschakeld. In die tijd waren de lonen relatief laag en bedrijfspensioenen nog betrekkelijk schaars. Werkende vrouwen kwamen al helemaal nauwelijks voor. Voor de cohorten die nu de 65 jaar gaan naderen, zijn veel van deze zaken veel gunstiger geweest. Natuurlijk, er bevinden zich in deze groep nog veel mensen met weinig scholing en met een hoge incidentie voor sociale zekerheid (WW, WAO, VUT), maar over het algemeen is het beeld toch positiever. Datzelfde geldt voor de gezondheid en voor de kwaliteit van de woningen. Gegeven deze ontwikkelingslijnen is de Raad dan ook voorstander van een specifiek beleid om de inkomensontwikkeling van diegenen die geen of nauwelijks extra inkomen bovenop hun AOW-uitkering hebben, te steunen.

\subsection{De positie van de grote steden}

In de voorafgaande drie paragrafen is de schijnwerper gericht geweest op drie onderscheiden groepen in de samenleving. Afgezien van de huisvestingsproblematiek van de allochtonen is daarbij de ruimtelijke dimensie niet aan de orde gekomen. Duidelijk is dat hiermee een relevant onderscheid onderbelicht wordt. De maatschappelijk ongelijke verdeling van beroep, onderwijs en inkomen kent namelijk ook een ruimtelijk aspect: het onderscheid tussen gebieden - regio's, gemeenten dan wel wijken - met een relatief gunstige verdeling qua maatschappelijke participatie en andere gebieden waar de uitkomsten in dat verband veel ongunstiger zijn. Het scherpst kan dit ruimtelijk onderscheid worden waargenomen in de grote steden. Niet voor niets wordt daar gesproken over 'armoedewijken', wijken met een hoge concentratie aan mensen met

109] Indicatief voor de vermogensvorming is ook de omvang van het eigen woningbezit. Deze neemt gedurig toe. Uitsplitsing naar leeftijd laat zien dat de leeftijdsgroepen tussen 40 en 55 jaar momenteel het hoogste aandeel eigen woningen hebben. Ook in dat perspectief zijn de vooruitzichten voor de ouderen van morgen niet ongunstig. Zie Centraal Bureau voor de Statistiek, Inkomen en consumptie 1994; Voorburg, 1994, figuren 4.3.1 en 4.3.2, blz. 80.

110] Zie L.A.P. Montijn e.a., Grote steden, grote kansen; Rapport van de externe commissie-grote stedenbeleid, Ministerie van Binnenlandse Zaken, 's-Gravenhage, 1989; en WRR, Van de stad en de rond; Rapporten aan de Regering nr. 37, 's-Gravenhage, Sdu Uitgeverij, 1990. 
een lage maatschappelijke participatie en met weinig vooruitzichten op verbetering. Vandaar dat in deze paragraaf op deze dimensie nader ingegaan wordt. Over de grote steden en over de problemen van bepaalde wijken daar is de afgelopen jaren al veelvuldig gepubliceerd ${ }^{110}$. Recentelijk heeft het SCP in het Sociaal en Cultureel Rapport 1996 een apart hoofdstuk aan deze problematiek gewijd 111 .

Uitgangspunt voor de beschouwingen in het onderhavige rapport is dat maatschappelijke participatie voor mensen tussen 15 en 65 jaar vooral kan worden gerealiseerd door middel van arbeidsparticipatie. Men draagt bij aan de maatschappelijke productie, is onderdeel van een organisatie, bouwt contacten op en creëert kansen om de eigen positie op de maatschappelijke ladder te verbeteren. Daarnaast verwerft men een inkomen. Voorwaarde is wel dat op de arbeidsmarkt voldoende banen aangeboden worden op het niveau waarop men is opgeleid. Is dit niet het geval, dan is de kans op werkloosheid, al dan niet via verdringing door hogergeschoolden, zeer groot.

Tabel 3.11 Ontwikkeling van de werkgelegenheid, 1973-1993

\begin{tabular}{lcccc}
\hline & $\begin{array}{c}\text { Procentuele verandering } \\
1973-1983\end{array}$ & 1983-1993 & Aandeel 1973 & Aandeel 1993 \\
\hline grote steden & 7 & 7 & 24 & 18 \\
Randgebieden grote steden & 19 & 47 & 10 & 14 \\
Rest Nederland & 5 & 29 & 66 & 68 \\
Totaal & 4 & 27 & 100 & 100 \\
\hline
\end{tabular}

Toelichting: De werkgelegenheid betreft banen van werknemers

Bron: SCP (1996), Sociaal en Cultureel rapport 1996, tabel 4.3

In de grote steden nu hebben zich de laatste 20,30 jaar ontwikkelingen voltrokken die de positie van de lagergeschoolden sterk negatief hebben beïnvloed. Naar tabel 3.11 aangeeft, is de werkgelegenheidsontwikkeling aan de aanbodkant in de grote steden achtergebleven bij de omringende regio's en bij het totaal. Terwijl de werkgelegenheid in de grote steden qua omvang nauwelijks veranderde, steeg de werkgelegenheid in de randgebieden juist bijzonder sterk. In de concurrentie tussen grote steden en hun randgebieden bleek dat de laatstgenoemde gebieden in toenemende mate aantrekkelijker worden als vestigingsplaats, vanwege hun bereikbaarheid - voor af- en aanvoer van (intermediaire) producten en voor personeel en klanten - en de beschikbaarheid van (ruime) bedrijfsterreinen. Voor grote steden stond hier weliswaar het agglomeratievoordeel tegenover, maar dit aspect moet het in toenemende mate afleggen tegen de afnemende bereikbaarheid. Verbetering van de vestigingsvoorwaarden van grote steden zou in dit beeld verandering kunnen brengen, maar tot op heden is dit beleid weinig succesvol geweest.

De werkgelegenheidsontwikkeling in de grote steden was de resultante van een relatief grote daling in de traditionele sectoren (landbouw, industrie, bouwnijverheid, openbaar nut, vervoer, transport en communicatie), een relatief achterblijvende toename in de commerciële diensten (handel, horeca, bank- en verzekeringswezen, zakelijke diensten, overige dienstverlenende bedrijven) en een toename van de niet-commerciële diensten (openbaar bestuur, onderwijs, gezondheidszorg, maatschappelijke zorg e.d.). Deze veranderingen hebben geleid tot een arbeidsmarkt met een post-industrieel

1'] Zie 5ociaal-Cultureel Planbureau (1996), op.cic., hoofdstuk 12; alsmede P. de Beer, 'Werkloosheid in de grote stad'; Tijdschrift voor Arbeidsvroogstukken, 1996, jrg. 12, nr. 3, blz. 215-232. Zie verder Tesser en Van Praag (1995), op.cit.; en Van der Wouden, op. cit. 
karakter ${ }^{112}$. Ongeveer 80 procent van de werkgelegenheid valt onder de dienstensector. Overeenkomstige veranderingen hebben zich voltrokken in de beroepenstructuur.

Ten opzichte van de randgebieden om de grote steden en de rest van Nederland wordt de beroepsbevolking in de grote steden gekenmerkt door een relatief groter aanbod van vrouwen, jongeren, ongehuwden, allochtonen, ongeschoolden en hooggeschoolden. Dit wordt deels bepaald door de aanwezigheid van veel opleidingen in de grote steden, die op hun beurt zorgen voor een grote instroom van jongeren. Diegenen die afstuderen en vervolgens in de grote stad blijven wonen, zullen relatief vaak jong, ongehuwd en hooggeschoold zijn.

In paragraaf 3.3.5 is al aangegeven dat ook allochtonen, om heel andere redenen overigens, tot nu toe sterk op de grote steden georiënteerd zijn. Problematischer is de groep der ongeschoolden, vaak maar niet altijd allochtoon. Ook deze groep neemt toe. Deze beide groepen vinden landelijk vooral emplooi in de traditionele sectoren. In de grote steden, met hun nadruk op de diensten, betekent dit dat deze groepen minder kansen hebben. Deze divergentie zou ongeveer de helft van het werkloosheidsprobleem in de grote steden verklaren 113 .

Tegelijkertijd wordt de toename van banen met een hoog opleidingsniveau voor een belangrijk deel vervuld door forenzen. De migratie vanuit de steden naar de omringende gebieden bestond en bestaat vooral uit beter verdienende, goed opgeleide personen in gezinsverband. Voor hun baan bleven deze mensen aanvankelijk aangewezen op de grote stad. Daarna kwamen er echter in toenemende mate ook banen in hun directe woonomgeving beschikbaar. Momenteel wordt ongeveer de helft van het aantal banen in de stad bezet door mensen van buiten de stad. De inkomende pendel in de grote steden nam sterk toe in de periode 1977-1985, waarna een stabilisatie optrad 114. Bij de uitgaande pendel is sprake van een gematigde toename, maar wel op een beduidend lager niveau.

Kortom, er zijn minder banen voor de laaggeschoolden in de grote steden ${ }^{115}$, en er is meer concurrentie met goed-opgeleide forenzen om de overige banen ${ }^{116}$. Volgens het SCP zijn er weinig aanwijzingen dat de hoge werkloosheid in de grote steden samenhangt met een afwijkende attitude van deze mensen ten opzichte van de arbeidsmarkt. Zij benutten wel minder zoekkanalen dan werklozen in de rest van het land, maar daar staat tegenover dat zij vaker solliciteren en minder hoge eisen stellen. Wel lijkt de geringe bereidheid om naar elders te verhuizen een serieuze belemmering te zijn om uit de werkloosheid te komen ${ }^{117}$. Het resultaat van al deze ontwikkelingen is dat de grote stad ten opzichte van de rest van het land, en vooral ten opzichte van de omringende regio's, relatief meer laaggeschoolden, meer werklozen en andere

112] Alleen Rotterdam laat nog een hoog aandeel voor de traditionele sectoren zien.

113] Zie Sociaal-Cultureel Planbureau (1996), op. cit., blz. 125.

114] Ibid., blz. 89.

115] Er zijn voor zover bekend geen gegevens over het forensgedrag van bewoners van grote steden naar buiten toe. Gelet op het gegeven dat laaggeschoolden een lagere woon-werk afstand laten zien dan hoger geschoolden, mede vanwege het geringere autogebruik, en gegeven het hoge aandeel laaggeschoolden in de grote steden, zou men mogen concluderen dat de mogelijkheden voor deze mensen om op banen buiten de steden te solliciteren beperkter zijn. Zie M. Hanou en M. Hofmans, 'Op weg naar het werk'; Supplement bij de sociaalecanomische moandstotistiek, 1994-4, blz, 5-18.

116] Wellicht is mede door die concurrentie van buiten het werkloosheidspercentage van hoog-opgeleide inwoners van grote steden ook hoger.

I1] Zie Sociaal-Cultureel Planbureau (1996), op. cit., blz. 125. 
uitkeringsgerechtigden kent, die tamelijk geconcentreerd in wijken met een lage sociale status wonen ${ }^{118}$.

Welke beleidsmogelijkheden zijn er om de structurele positie van de stedelijke laaggeschoolden te verbeteren? In de eerste plaats ligt het voor de hand om het opleidingsniveau van deze mensen te verbeteren. Dit gebeurde en gebeurt ook, en het heeft voor een aantal mensen zeker tot een verbetering van hun arbeidsmarktpositie geleid. Eerder is al opgemerkt dat de zogenoemde inburgerings'-contracten hier een belangrijke bijdrage kunnen leveren. Speciaal voor de allochtone laaggeschoolden geldt dat een verbetering van hun situatie langs deze weg een lange adem vergt. Tegelijk moet men zich ook de vraag stellen naar de rentabiliteit van dergelijke inspanningen. Naarmate het aantal laaggeschoolden verder afneemt, zal het steeds moeilijker worden om de nog overgebleven personen in deze categorie te scholen. De vraag is onontkoombaar of de hiermee nog te bereiken verbeteringen wel opwegen tegen de kosten.

Een tweede mogelijkheid is om via de huisvesting de kansen van deze groep te beïnvloeden. Dit komt neer op een grotere migratie vanuit de grote steden naar omringende gebieden, dan wel naar andere regio's, waar meer werkgelegenheid voor laaggeschoolden bestaat. Aan de ene kant betekent dit waarschijnlijk een aanpassing van het woningbouwprogramma in de ontvangende gebieden, aan de andere kant een grotere bereidheid dan tot nu toe waarneembaar is geweest van laaggeschoolden in de grote steden om te verhuizen omwille van het arbeidsmarktperspectief. De vraag is ook hoe groot de maatschappelijke druk moet zijn. Gegeven de huidige vestigingspatronen is de voorkeur voor de grote stad aanzienlijk. Als een dergelijk herhuisvestingsbeleid al effect heeft, dan is dat pas op de langere termijn. Eerst moet huisvesting beschikbaar komen. Tegelijkertijd moet bedacht worden dat ook in die regio's de werkgelegenheidskansen voor laaggeschoolden eerder zullen verslechteren dan verbeteren.

De derde mogelijkheid is het aanbod van laaggeschoold werk in de grote steden te vergroten, waardoor de kansen van laaggeschoolden op werk kunnen toenemen. Ook deze beleidslijn heeft in het verleden al veel aandacht gekregen, namelijk via de creatie van zogenoemde additionele arbeid, speciaal gericht op het scheppen van werk voor laaggeschoolden. In het wat verdere verleden heeft dit geleid tot projecten als Kaderregeling arbeidsinpassing, banenpools en Jeugd Werk Garantieplannen. In de afgelopen jaren zijn hier vier andere vormen van additionele arbeid bijgekomen, kortweg aangeduid als Melkert-I tot en met Melkert-IV. De intentie is dat in 1998 ongeveer 200.000 langdurig werklozen een dergelijke additionele arbeidsplaats zullen bezetten, een toename van ongeveer 75.000 ten opzichte van de situatie in 1994. Daarmee zou de werkloosheid van langdurig werklozen, veelal laaggeschoolden, met ongeveer een derde kunnen worden teruggedrongen.

$B i j$ veel maatregelen is de veronderstelling dat men van hieruit doorstroomt naar regulier werk. Gegeven de werkgelegenheids- en werkloosheidsontwikkeling is dit echter een tamelijk heroïsche veronderstelling. Wat gebeurt er als de verhoopte werkgelegenheid uitblijft? Mogen mensen dan langer dan gepland in deze regeling blijven, of vallen ze terug in de werkloosheid? In het eerste geval zou dit neerkomen op het scheppen van een groot aantal gesubsidieerde banen, die qua status waarschijnlijk minder zullen zijn dan normale banen. Tegelijk zullen de mogelijkheden voor toekomstig langdurig werklozen om via deze additionele banen terug te keren naar de reguliere arbeidsmarkt afnemen. Nog minder aantrekkelijk lijkt de optie om in het werklozenbestand

118] Ibid., hfdst. 4, 5 en 12. 
terug te keren. De kans dat men daardoor mensen volledig voor de arbeidsmarkt afschrijft, is zeer wel aanwezig.

Toch is deze weg, de creatie van nieuwe banen, aangepast aan de opleidingskwalificaties van het aanwezige werkloosheidsbestand, waarschijnlijk de beste. Meer dan tot nu toe zou hierbij het uitgangspunt moeten zijn dat in een moderne, stedelijke samenleving behoefte bestaat aan een omvangrijk pakket van arbeidsintensieve, maar ook relatief eenvoudig te verlenen diensten, waarvoor afnemers bereid zijn te betalen en die geëigende werkgelegenheid kunnen creëren voor laaggeschoolden. Een dergelijke benadering wijkt sterk af van het tot nu toe gevoerde beleid. Uitgaande van een loonontwikkeling die in de particuliere sector en in (semi-)collectieve diensten min of meer overeenkomstig was, gegeven de observatie dat de productiviteitsontwikkeling in tal van niet-commerciële diensten structureel lager is dan in andere sectoren, en onder druk van de doelstelling om de overheidsuitgaven - ook die voor de productie van uiterst relevante diensten in sectoren als onderwijs en gezondheidszorg - waar mogelijk terug te brengen, is ook in deze dienstensectoren het behoud van een arbeidsplaats afgemeten aan de productiviteit dan wel het beschikbare budget. Eerder al heeft de WRR aannemelijk gemaakt dat de werkgelegenheidsontwikkeling in dit land gekenmerkt werd door een negatieve spiraal: hoge loonkosten spoorden aan tot productiviteitsverbetering, die niet zelden gerealiseerd kon worden via het doen verdwijnen van de minderproductieve, laaggeschoolde werknemers in enigerlei sociale zekerheidsregeling. Hierdoor liepen de premies verder op en zo ook de loonkosten ${ }^{119}$. Het gevolg was dat de arbeidsproductiviteit in Nederland weliswaar bijzonder hoog was, maar dat de arbeidsparticipatie en het BNP per hoofd juist aan de lage kant waren. Verder werd aangegeven dat de werkgelegenheid in tal van sectoren, uitgedrukt per 100 inwoners, in Nederland beduidend lager lag dan in landen als Zweden en de Verenigde Staten.

In hoofdstuk 2 is aangegeven dat de ontwikkeling van de werkgelegenheid de laatste jaren een keer ten goede heeft gemaakt en dat ook de vooruitzichten niet ongunstig zijn. Tegelijkertijd is duidelijk dat de positie van laaggeschoolden op de arbeidsmarkt vooralsnog slecht zal blijven. Verhoging van hun opleidingsniveau of verlaging van hun loonkosten lijken onvoldoende effectief te zijn om hierin verbetering te brengen. Dit betekent dat ook andere opties overwogen zouden moeten worden. Gegeven de hoge werkloosheid van laaggeschoolden in de grote steden en de observatie dat juist daar ook nu nog veel onvervulde taken bestaan, is het gewenst om uit te zoeken welke mogelijkheden er zijn om structureel nieuwe banen voor deze groep te scheppen, waarmee maatschappelijk relevante arbeid verricht kan w.orden en waarbij wordt aanvaard dat de uitgaven voor sociale zekerheid voor deze groep slechts zullen dalen wanneer de overheidsuitgaven voor deze activiteiten worden verhoogd. In het slothoofdstuk zal op deze materie worden teruggekomen.

\subsection{De gemeenschappelijke factor: laaggeschooldheid}

In dit hoofdstuk is de emancipatie van een aantal kansarme groepen verkend. Omvang en maatschappelijke aandacht waren bepalend voor de keuze van de groepen. Achtereenvolgens ging het over de vrouwen, de allochtonen en de ouderen. Duidelijk werd dat het proces van emancipatie voor velen in de desbetreffende groepen succesvol heeft uitgewerkt. Tegelijkertijd werd ook duidelijk dat datzelfde proces van emancipatie niet heeft kunnen voorkomen dat mensen binnen de respectievelijke groepen achterbleven en soms zelfs verder achterop raakten. Gemeenschappelijk kenmerk daarbij was de mate van scholing. Steeds weer waren het de laaggeschoolden, die niet of in onvoldoende mate konden participeren, met name ook op de arbeidsmarkt. 
Onlangs heeft het SCP een publicatie uitgebracht ${ }^{120}$, waarin wordt betoogd dat deze verslechterde positie niet was terug te voeren op een dalend aantal banen voor laaggeschoolden. Integendeel, de conclusie luidde dat ook nu nog ongeveer een kwart van de banen zich aan de onderkant van de arbeidsmarkt bevindt, op basis van een oordeel over betaling, scholing, flexibiliteit en arbeidsomstandigheden ${ }^{121}$. Weliswaar daalt het aantal lager geschoolde banen met slechte arbeidsomstandigheden, maar daartegenover staat een toename van laag betaald en flexibel werk. Gaat men af op functieniveau dan wel op scholingsniveau op basis van de EBB, dan is er echter wel sprake van een duidelijke afname van het onderste arbeidsmarktsegment ${ }^{122}$. In absolute zin is die daling weliswaar gering, maar gegeven de toename van de totale werkgelegenheid is hier sprake van een duidelijke daling.

Wordt naar de aanbodkant gekeken, dan blijkt, in lijn met eerder vermelde bevindingen in dit rapport, er sprake te zijn van een duidelijke daling van het aanbod van laaggeschoolden en een duidelijke oververtegenwoordiging van allochtonen. Tegelijk moet beseft worden, aldus het SCP, dat driekwart van de banen aan de onderkant van de arbeidsmarkt bezet wordt door autochtonen en personen ouder dan 25 jaar, voor de helft door middelbaar en hoger opgeleiden. Laagopgeleiden en allochtonen hebben een relatief grote kans om hun baan te verliezen en werkloos te worden, en een betrekkelijk geringe kans om weer aan de slag te raken.

Dat de werkloosheid onder laaggeschoolden (en daaronder allochtonen) zoveel hoger en structureler is dan voor anderen, is dus volgens het SCP niet terug te voeren op een daling van het aantal bij deze groep passende banen. Veel meer wordt de oorzaak gezocht in de conjuncturele kwetsbaarheid van veel van deze banen, in de verdringing van laaggeschoolden op die posities door beteropgeleiden en in de slechte fit van het zoekgedrag van werklozen en potentiële werkgevers. Volgens het SCP is het huidige overheidsbeleid, waarin veel gebruik gemaakt wordt van financiële prikkels, weinig effectief. Werkgevers zoeken niet zozeer goedkope als wel goede arbeidskrachten, werknemers zoeken niet zozeer goed betaalde als wel aantrekkelijke banen. De mogelijke aansluiting tussen vraag en aanbod kan op zichzelf worden verbeterd door werknemers te scholen, dan wel door de loonkosten aan de onderkant in de vorm van belasting- of premievrijstelling te verlagen. Een werkelijke verbetering van de arbeidsmarktsituatie aan de onderkant van de arbeidsmarkt wordt echter pas gerealiseerd bij sterke algehele werkgelegenheidsgroei, aldus het SCP ${ }^{123}$.

Daarmee wordt teruggekeerd naar deze studie. In het vorige hoofdstuk is verkend hoe de arbeidsmarkt zich tot 2015 zou ontwikkelen, op basis van aannames betreffende vraag en aanbod. Grosso modo waren de conclusies niet in mineur. Uitgaande van een gematigde groei van de werkgelegenheid

120] Zie P. de Beer, Het onderste kwart Werk en werkloosheid aan de onderkant van de orbeidsmorkt; Rijswijk, SCP. 1996.

121] Daarbij moet overigens worden opgemerkt, dat de verschillen binnen dat onderste kwart opmerkelijk groot zijn. Op basis van een uitgebreide statistische analyse op basis van gegevens uit 1995. wordt een indeling in 7 groepen gemaakt. Op de schaal van 0 tot 10, blijkt 4 procent van de banen zich te bevinden in het eerste cluster, met een, lage, waardering van 2,7. De volgende twee clusters, met 23 procent van de werkgelegenheid, komen uit op een waardering van ongeveer 5 . De daarop volgende drie clusters, met $\$ 2$ procent van de banen, kent een waardering van 7, en voor 20 procent van de banen komt het hoogste cluster op een waardering van bijna 9. Men kan zich de vraag stellen of het verantwoord is de eerste drie clusters samen te voegen, gelet op het grote verschil in waardering tussen de clusters I en 2/3. Daarmee komen de onderlinge verschillen onvoldoende naar voren. Daarnaast valt het te betreuren dat deze analyse niet voor eerdere jaren kon worden toegepast, op basis van gelijke criteria. Pas dan zou men tot harde uitspraken over het verloop van de banen aan de onderkant hebben kunnen komen. Zie De Beer (1996), op.cit., blz. 54.

122] Zie De Beer (1996), op.cit, blz. 61-62.

123] Ibid., hfdst. 7. 
- gematigd in vergelijking met de feitelijke ontwikkeling in de afgelopen jaren - en rekening houdend met de demografische ontwikkeling, wordt voorzien dat al vanaf ongeveer 2005 een structurele daling van de werkloosheid kan gaan optreden. Dit geldt zeker als het arbeidsaanbod zou stabiliseren op het huidige niveau. Maar zelfs als het arbeidsaanbod verder zou groeien, met name dan bij de vrouwen, zijn de vooruitzichten niet ongunstig te noemen. Ook bij de analyse in dit hoofdstuk bleek dat de verwachtingen voor de meeste groepen niet negatief zijn. Dit heeft te maken met reeds in gang gezette ontwikkelingen die de structuurkenmerken van de onderscheiden groepen in positieve richting hebben bijgesteld. Hierbij gaat het om de mate van opleiding en om de arbeidsparticipatie. De toename hiervan zal gunstig uitwerken op de kansen op werk, op een redelijk inkomen tijdens en na een arbeidzaam leven en op de maatschappelijke participatie in het algemeen. Deze positieve vooruitblik geldt vooral voor vrouwen en ouderen.

Nog het minst rooskleurig zijn de vooruitzichten voor de allochtone groepen. Hun geringe scholing, de nog toegenomen achterstand qua scholing van de tweede generatie op de autochtonen, de kans op een nieuwe instroom van laaggeschoolden en daardoor kansarmen, alsmede hun huisvestingssituatie zijn evenzovele indicaties dat de kansen op maatschappelijke participatie van deze groep, gegeven de huidige situatie, als problematisch moeten worden beschouwd. Dit kan leiden tot sociale segmentatie. Of deze situatie zich zal voordoen, hangt in belangrijke mate af van de ontwikkeling van de arbeidsmarkt. Ruimt deze niet, blijven er velen werkloos of moeten de kansen op werk voor laaggeschoolden somber worden ingeschat, dan is een proces van sociale segmentatie niet uit te sluiten. Wanneer de sociaal-economische ontwikkeling echter volgens een ander patroon verloopt, met betere kansen op werk ook voor deze groep, zijn de vooruitzichten heel anders. De analyse in het vorige hoofdstuk leverde op dat ook kansen op een zonniger perspectief aanwezig zijn.

De beschouwingen in dit hoofdstuk monden aldus uit in de conclusie dat een analyse van het verschijnsel tweedeling zich niet moet richten op zulke algemene categorieën als vrouwen, allochtonen en ouderen, maar veel scherper zal moeten kijken naar de maatschappelijke participatie van de laaggeschoolden. Het zijn juist de laaggeschoolden die voor een onmogelijke keuze worden geplaatst. Ofwel moeten ze trachten hun kennisniveau te verbeteren, maar gegeven de verdeling van vaardigheden over individuen zal er altijd een groep mensen blijven die niet in staat is om meer dan een basale opleiding te volgen. Ofwel hun maatschappelijke participatie wordt geblokkeerd op basis van een vergelijking van hun loonkosten en productiviteit. Wat resteert, is dan een uitkering. Steeds duidelijker blijkt dat geld geen voldoende voorwaarde is voor adequate maatschappelijke participatie. Dan rijst de vraag of er wellicht andere mogelijkheden zijn om deze groep meer kansen te geven op meer maatschappelijke participatie. Over de mogelijke opties in deze richting gaat het slothoofdstuk. 


\section{Om de kwaliteit van de toekomst}

\section{I Over dimensies en groepen; een eerste balans}

Uit de voorgaande analyses kwam naar voren dat de in Nederland traditioneel hoge mate van formele inactiviteit steeds meer in termen van uitsluiting en steeds minder in termen van bescherming werd beschouwd. Deze sociaalculturele omslag van de jaren zeventig en tachtig kon door de ontwikkeling van de werkgelegenheid niet worden bijgebeend, hetgeen de maatschappelijke cohesie op de proef stelde.

Daarnaast kon echter ook worden vastgesteld dat de sociaal-economische kansen of randvoorwaarden voor een cohesieve maatschappelijke ontwikkeling in de komende twintig jaar thans vermoedelijk gunstiger zijn dan voorheen. Vergeleken met de afgelopen twee decennia lijkt een harmonischer ontwikkeling derhalve tot de mogelijkheden te behoren. Dit heeft er vooral mee te maken dat de arbeidsmarkt de inhaalslag van een groeiend arbeidsaanbod langzamerhand aan het verwerken is. Als deze ontwikkeling doorzet, zou dit er op betrekkelijk korte termijn zelfs toe kunnen leiden dat in bepaalde kennisintensieve sectoren arbeidsmarktkraptes zullen ontstaan. De effecten van een dergelijke arbeidsmarktontwikkeling op de beide andere verdelingsdimensies (onderwijs en inkomen) zijn niet te verwaarlozen. Zo kan het onderwijs zich voorbereiden op een situatie waarin het volgen van een opleiding weer (of: meer nog dan thans) loont; het debat over overscholing en diplomainflatie zal dan naar de achtergrond verdwijnen ${ }^{1}$. De onevenwichtigheden die de verhouding van onderwijs en arbeidsmarkt de afgelopen jaren hebben beheerst, zullen plaats maken voor een sterker accent op vorming, waardoor een betere en flexibeler aansluiting op de arbeidsmarkt mogelijk zal worden. Daarnaast zullen steeds meer mensen via de arbeidsmarkt een inkomen kunnen verwerven.

Toch moeten hier ook enige kanttekeningen worden geplaatst. De gunstige ontwikkeling van de arbeidsmarkt zal waarschijnlijk slechts een beperkt positief effect hebben voor degenen met een laag scholingsniveau. Aan de onderkant van de arbeidsmarkt zal door 'ontdringingsverschijnselen' weliswaar enig soelaas worden geboden, maar voldoende zal dit zeker niet zijn ${ }^{2}$. In het licht van de oorspronkelijke vraag van dit rapport, ligt hier een serieuze kans op maatschappelijke frictie. Het is zaak hier in dit hoofdstuk nader op in te gaan.

In hoofdstuk 3 werd ingegaan op groepen of categorieën (vrouwen, allochtonen, ouderen) die in de tweedelingsdiscussie veel aandacht krijgen. Hier deed zich een vergelijkbare sequens voor. De onderscheiden groepen of categorieën bleken langzamerhand intern zozeer te verschillen qua maatschappelijke kansen en bereikte resultaten, dat het geen relevant beleidsdoel meer dient alle vrouwen, alle allochtonen, alle ouderen of alle stedelingen over één kam te scheren. Integendeel, hoewel deze beleidsoriëntatie op afgebakende groepen vroeger zeker nut heeft gehad, zou het tegenwoordig onbedoelde discriminerende effecten kunnen hebben wanneer zulke categorieën worden gehandhaafd terwille van te voeren beleid ${ }^{3}$. 
Maar ook hiermee is lang niet alles gezegd. Als categorie mogen vrouwen, ouderen en allochtonen dan minder een probleem gaan vormen, dit betekent niet dat er binnen deze categorieën geen problemen zouden bestaan. Naast de etnische, sekse-, leeftijds- of ruimtelijke factoren speelt hierbij vooral de combinatie een rol van lage scholing en het afgesloten zijn van de arbeidsmarkt. Bijna steeds wanneer vrouwen, allochtonen, ouderen of stedelingen (maar ook mannen, autochtonen, jongeren en plattelanders) in problemen komen, is het de combinatie van lage scholing en het aangewezen zijn op een uitkering vanwege onvrijwillige werkloosheid, arbeidsongeschiktheid of het verrichten van (informele) zorgtaken -, die hiervan de achtergrond vormt. De mate waarin de scholing en ervaring van elk individu passen bij de eisen van de arbeidsmarkt, heeft zich dan ook ontwikkeld tot de meest elementaire voorwaarde voor een cohesieve sociaal-culturele ontwikkeling. De individuele $f t$ van scholing en arbeidsmarkt heeft een zwaarder accent gekregen; de eventuele misfit groeide uit tot de belangrijkste oorzaak van maatschappelijke achterstand en uitsluiting.

In de naoorlogse periode is dit een betrekkelijk nieuw verschijnsel. Van een belangrijk deel van de bevolking was het niet-deelnemen aan betaalde arbeid immers volstrekt normaal. Sterker nog: volwassen vrouwen hoorden daar zelfs niet aan deel te nemen. Hun aansluiting met de wereld van de arbeid verliep via de kostwinner. Met de emancipatie- en individualiseringsprocessen van de laatste drie decennia is dit veranderd. Dat ging niet gemakkelijk, want op de arbeidsmarkt was de te benutten ruimte door de elkaar opvolgende economische crises verkleind. Het mocht dan ook geen wonder heten dat de opvattingen van een groot deel van de bevolking (en hun politieke leiders) in een andere richting wezen. Voor de behoudende groep was de sociaalculturele normaliteit van het kostwinnersgezin tot norm uitgegroeid; een norm, die, eenmaal bedreigd, hardnekkig werd verdedigd. Voor het meer progressieve deel van de bevolking was de fit om een andere reden uit het zicht verdwenen: voor hen had de arbeidssamenleving haar langste tijd gehad. Beide opvattingenstelsels zijn inmiddels schipbreuk aan het lijden of hebben dit reeds gedaan. Voor de komende twintig jaar mag er dan ook van worden uitgegaan dat de sociaal-culturele samenhang en verscheidenheid van onze samenleving pas werkelijk zullen floreren als scholing en arbeidsmarkt weer aansluiten, ook op individueel niveau.

In dit slothoofdstuk wordt een aantal ontwikkelingen geschetst die zich naar het oordeel van de Raad in het huidige spanningsveld van scholing en arbeidsmarkt zullen kunnen voordoen. Deze formulering is welbewust voorzichtig gehouden, omdat de focus ligt op de huidige en toekomstige interactie van feitelijke ontwikkelingen èn ontwikkelingen in opvattingen. Empirische en teleologische beschouwingswijzen wisselen elkaar dan noodgedwongen af. Gedeeltelijk betreft het ontwikkelingen van feiten en opvattingen die zich thans reeds aftekenen; deze hebben dus een min of meer empirische basis. Maar zeker zo belangrijk is het na te gaan wat de consequenties van deze ontwikkelingen zullen kunnen zijn. Dit is wat wordt bedoeld met teleologische of functionalistische beschouwingswijzen. Bijvoorbeeld: als de behoefte aan arbeidsparticipatie zich zal blijven doorzetten, dus als het steeds belangrijker wordt werk te hebben, wat betekent dit dan voor de beoordeling van degenen die niet aan werk kunnen komen? Zullen degenen aan de onderkant van de scholings- en arbeidsmarkt voor wie nauwelijks of geen plaats is, nog scherper dan thans worden uitgesloten? En wat zou dit gaan betekenen voor de inrichting van de arbeidsmarkt en voor de inrichting van het sociale-(zekerheids)stelsel? Of een ander voorbeeld: als het belang van onderwijs en opleiding in een kennisintensieve samenleving naar verwachting alsmaar groter wordt, wat betekent dit dan voor degenen die daarin niet kunnen meekomen of voor degenen die niet de kans krijgen om door ervaring wijzer te worden? Zal dit tot een nog scherpere cesuur van insiders en outsiders leiden of zal 
misschien de negatieve opvatting over laaggeschooldheid in een kennisintensieve samenleving worden bijgesteld? Dergelijke beschouwingen betreffen steeds de interactie van feiten en opvattingen, en ontstijgen derhalve het niveau van de empirische beschouwing alleen. Ze weerspiegelen het hoofdprobleem van een sociaal-culturele toekomstverkenning: de moeilijk traceerbare dynamiek van hoe feiten de opvattingen veranderen en veranderde opvattingen andere feiten onder de aandacht brengen.

In hoofdstuk 1 is het maken van een sociaal-culturele toekomstverkenning vergeleken met kleiduivenschieten vanuit een roller coaster: de baan van de duif valt te berekenen, de bewegingen van de roller coaster eventueel ook, maar de manier waarop die twee samengaan, kan het leven van de schutter flink zuur maken. De parallel met de sociaal-culturele wereld lag voor het oprapen: feitelijke ontwikkelingen kunnen worden achterhaald (al is dit niet zo eenvoudig als men het vaak doet voorkomen, getuige de sociaal-culturele bepaaldheid van de concepten die aan de 'feiten' vooraf gaan); ook verschuivingen in opvatting kunnen worden gedocumenteerd en gerubriceerd. Maar met hun onderlinge relatie ligt het een stuk moeilijker. Voor wat het verleden betreft, zou een en ander, ondersteund door een nieuwe schikking van empirisch materiaal, kunnen worden hineininterpretiert, maar voor de toekomst gaat de empirische basis waarop wetenschappelijke uitspraken over de relatie van feiten en opvattingen moeten worden gedaan per definitie verloren.

Toch is deze complexe verhouding van feiten en opvattingen tegelijk de essentie en de uitdaging van elke sociaal-culturele toekomstverkenning. Onder erkenning hiervan heeft de Raad een aantal overwegingen bijeengebracht waarvan hij, redenerend vanuit het heden, verwacht dat zij, gegeven de voorafgaande analyses, de toekomst in aanzienlijke mate zullen bepalen.

Vier thema's worden hieronder nader uitgewerkt, het eerste meer methodologisch en kennissociologisch van aard, de andere drie vooral inhoudelijk. Het eerste thema grijpt in het hart van de vraagstelling van deze studie (zie hfdst. 1) en geeft ten minste een gedeeltelijke verklaring voor de grote discrepantie tussen de tamelijk sombere sociaal-culturele toekomstverwachtingen waarnaar dit rapport verwees en de tamelijk gunstige toekomstmogelijkheden die uit de eigen analyses volgden. In de desbetreffende paragraaf (4.2) wordt nader ingegaan op de sociaal-culturele en sociaal-historische gebondenheid van de concepten waarmee de wereld van mens en maatschappij wordt bestudeerd. Betoogd wordt dat de bovengenoemde discrepantie voor een deel herleid kan worden op het gebruik van concepten die in een eerdere sociaalculturele periode wèl adequaat waren maar dit thans in veel mindere mate zijn ${ }^{4}$.

Het tweede thema behandelt de emancipatie van de arbeid, dat wil zeggen: het geleidelijke, inmiddels al een eeuw durende proces van kwaliteitsverandering van arbeid. Dit thema bouwt voort op paragraaf 2.2 en de aldaar gedane suggesties. Pas sinds enkele jaren is de betekenis van dit veranderingsproces tot ons doorgedrongen en is duidelijk geworden hoe de emancipatie van arbeid het gezicht van de samenleving fundamenteel heeft veranderd en nog steeds aan het veranderen is. Daar zicht op hebben, is voor een toekomstgericht beleid van groot belang. De consequenties voor de sociaal-economische orde en voor de inrichting van het stelsel van sociale zekerheid zijn nog maar nauwelijks doorgrond. In paragraaf 4.3 worden de contouren

4] Daarnaast bestaan er natuurlijk nog tal van andere factoren die die discrepantie helpen te verklaren. Zo is het feit dat veel wetenschap gericht is op probleemidentificatie en dat eenmaal geïdentificeerde problemen een brede verspreiding krijgen via de massamedia, ongetwijfeld van invloed. Men moet ook niet vergeten dat ook in de jaren vijftig de notie van een 'crisis' het maatschappelijke discours bepaalde. 
geschetst van een sociaal stelsel dat voortbouwt op dit proces van arbeidsemancipatie. Het blijft daar overigens slechts bij contouren. In een volgend rapport zal de Raad ingaan op de eisen die aan een stelsel van sociale zekerheid moeten worden gesteld, wanneer de verruiming van de arbeidsparticipatie daarbij als doelstelling wordt gekozen ${ }^{5}$.

Het derde thema biedt onder de noemer van de emancipatie van talent (hetgeen betekent alle talent) een uitwerking van één van de hoofdvragen van de sociale samenhang in de (nabije) toekomst: de verhouding tussen meritocratie, menselijke waardigheid, sociale gelijkheid, de rol van het onderwijs en scholing en de positie van laaggeschooldheid. In paragraaf 2.3 werd reeds ingegaan op de betekenis van het onderwijs om sociale gelijkheid te realiseren; daar werd ook reeds gewezen op de beperkingen die hieraan zijn verbonden. In paragraaf 4.4 wordt deze kwestie verder opgenomen. Hier wordt betoogd dat de identificatie van intellectuele of cognitieve vaardigheid met menselijke waardigheid tot een vorm van sociale ongelijkheid leidt die in essentie niet anders is dan toen sociale ongelijkheid vooral op sociale herkomst was gefundeerd. Ook die herkenning verloopt moeizaam, maar zou uiteindelijk wel eens kunnen uitmonden in de afbraak van deze identificatie, waardoor zowel aan de boven- als aan de onderkant van de talentenverdeling meer ruimte zal ontstaan. Toekomstverwachting en 'wishful thinking' komen hier ongetwijfeld dicht bij elkaar, maar de Raad gaat ervan uit, dat een meritocratie die de (gelijk)waardigheid van mensen afhankelijk maakt van intellectuele competentie in strijd komt met de grote betrokkenheid van onze cultuur op sociale gelijkheid 6 . In het verlengde van die gedachte wordt deze paragraaf afgesloten met een pleidooi voor de emancipatie van de laaggeschooldheid.

Ten slotte gaat de Raad in het vierde thema in op de kernvraag van de sociaal-culturele samenhang van de eenentwintigste eeuw: is solidariteit in een gefragmenteerde of geïndividualiseerde samenleving mogelijk en, zo ja, hoe ziet die er dan uit? De afgelopen decennia hebben in het teken gestaan van een steeds voortschrijdende ontzuiling. De verticale of kolomsgewijze indeling van de samenleving heeft hierdoor aan belang ingeboet. Naar de mate dat het criterium van religieuze affiliatie als maatschappelijk indelingscriterium naar de achtergrond verdween, kwam in de jaren zeventig en tachtig het accent in toenemende mate op de maatschappelijke ongelijkheid van sociaaleconomische lagen of strata te liggen. De vraag is of nu en in de toekomst ook deze horizontale lagenstructuur niet in afnemende mate relevant wordt voor de organisatie van de samenleving. Betekent individualisering van maatschappelijke problematiek uiteindelijk niet ook - zo luidt dan de vraag - dat naast ontzuiling ook ontlaging zich als maatschappelijk proces zal doorzetten? En als ook die vorm van groepssolidariteit gaat eroderen, wat is dan het cement dat een steeds amorfere samenleving bijeen weet te houden? In paragraaf 4.5 wordt hierop ingegaan.

Ten slotte wordt in paragraaf 4.6 de balans opgemaakt en worden de hoofdgedachten van dit slothoofdstuk in beleidstermen vertaald.

\subsection{De 'Seinsverbundenheit des Wissens' 7}

Eén van de opvallendste verschijnselen in de huidige sociaal-culturele toekomstverwachting is de discrepantie tussen de ontwikkeling in feiten en in

5] Rapport over de toekomst van de sociale zekerheid, te verschijnen in het voorjaar van 1997.

6] W.Th.M. Frijhoff, Eigenzinnig Nederland; het verleden in de toekomst van een cultuurnatie; NWO-O.K. en W. voorjaarslezing. 8 mei 1996, Den Haag, K.L. Pollstichting, NWO, 1996.

] Cf. Karl Mannheim, 'Wissenssoziologie'; in: Alfred Vierkandt, Hondwörterbuch der Soziologie; Stuttgart, Enke. I939; later als hoofdstuk V opgenomen in: Ideology and Utopia; An Introduction to the Sociology of Knowledge; London, Kegan Paul, 1936, blz. 237-280. 
opvattingen. De hoge mate van somberheid en pessimisme die veelal over de te verwachten ontwikkelingen wordt gehoord, contrasteert met de over het algemeen perspectiefrijke toekomst die in de voorgaande analyses werd geschetst. Door reeds aan het begin van deze studie aandacht hiervoor te vragen, is voorkomen dat ééndimensionale en mechanistische extrapolaties het beeld van de toekomst zouden bepalen. Twee denkbewegingen liggen hieraan ten grondslag.

Op de eerste plaats bestaat de mogelijkheid dat feitelijke ontwikkelingen als desastreus worden herkend en dat vervolgens wordt opgeroepen tot beleid, dat de gevreesde uitkomsten voorkomt. De wal van de opvattingen keert dan als het ware het schip van de feitelijke ontwikkelingen door op adequate wijze koerscorrecties uit te voeren. Overigens moet ook hier niet te mechanisch worden gedacht. 'Objectieve' ontwikkelingen worden immers vaak pas als desastreus herkend, als ze door externe oorzaken al wat minder desastreus aan het worden zijn. Vormden de jaren vijftig bijvoorbeeld de hoogtij van sekse-ongelijkheid, toch werd er toen weinig gesproken over discriminatie van de vrouw. Die werd pas als probleem herkend toen de vanzelfsprekendheid van de traditionele sekserollen begon te verrafelen en een beperkt aantal vrouwen zich hieraan ook werkelijk wist te ontworstelen 8 . Een ander, meer recent voorbeeld is de leeftijdsdiscriminatie. Ouderenbescherming is lange tijd meer als verworvenheid dan als maatschappelijk probleem beschouwd. Ook hier was pas sprake van een probleem toen het begin van een nieuwe oplossing voorhanden was.

Maar het kan natuurlijk ook voorkomen dat dezelfde, ooit als negatief ervaren ontwikkelingen in een ander, positiever, licht komen te staan. Ook in dit geval volgt de ideologie de werkelijkheid. Voorbeelden zijn er genoeg. Toen de uitstoot van industriële arbeid serieuze vormen ging aannemen, begon het al eerder door Fourastié gelanceerde vrijetijdsdenken ook in Nederland aan te slaan ${ }^{9}$. Van verschillende kanten is erop gewezen dat de 'goedheid' van het sociale stelsel een uitvloeisel is van de economische noodzaak om mensen op de been te houden ${ }^{10}$. Nog maar twee jaar geleden viel het pleidooi voor meer banen tussen het wettelijk minimumloon en de laagste loonschalen van de CAO's slecht; thans vormt het een speerpunt van beleid ${ }^{11}$. Nog concreter is het voorbeeld van de flexibilisering, waar de discussie zich thans precies concentreert op de vraag of flexibilisering voortaan als een positief dan wel als een negatief verschijnsel moet worden beschouwd ${ }^{12}$.

De erkenning van deze complexe interactie van feiten en opvattingen relativeert zowel de eendimensionale vooruitberekeningen van objectieve ontwikkelingen als de tendenties die men soms in opinie-onderzoeken meent waar te nemen. Zeker in een sociaal-culturele toekomstverkenning is het zaak een greep achter die oppervlakkige werkelijkheden te doen.

8] In dezelfde lijn is gesignaleerd dat het besef van milieucatastrofen juist sterker werd toen de politiek vorderingen maakte bij de reductie van milieuproblemen; cf. Volker von Prittwitz. Das Katastrophenparadox; Elemente einer Thearie der Umweltpolitik; Opladen, Leske \& Budrich, 1990.

9] J. Fourastié, 40.000 uur. De mens in het perspektief van een verkorte orbeidstijd; Hilversum/Antwerpen, 1966; Bart van Steenbergen, In de praeftuin van de samenleving; de post-materialistische moatschappij als voorbeeld van ontwerpsocialogie, deel II; Amersfoort, De Horstink, 1983; Th. Beckers, "s Morgens jagen, 's middags vissen en 's avonds veetelen en kritiseren. Arbeid en recreatie in 1998, een concrete utopie'; Recreatie '98, 's-Gravenhage, 1978, blz. 57-73.

10] Vgl. Abram de Swaan, Zorg en de Stoat; welzijn, onderwijs en gezondheidszorg in Europo en de Verenigde Stoten in de nieuwe tijd; Amsterdam, Bert Bakker, 1988.

1] Vgl. Saciale zekerheid bij de tijd; PvdA projectgroep (vz. Karin Adelmund), 1996.

12] Vgl. FNV, Flexibilisering van arbeid; Amsterdam, 1995; FNV, Tijd voor zekerheid; Amsterdam, 1995. 
In de interactie tussen tussen feiten en opvattingen en het uiteenlopen hiervan speelt één verschijnsel een belangrijke rol: het contrast tussen het 'exclusieve' en het 'inclusieve' vocabulaire. In het gangbare sociaal-economisch onderzoek en beleid wordt over het algemeen een calculus gebruikt die grote affiniteit heeft met de sociaal-culturele werkelijkheid van de naoorlogse decennia. Zo wordt werkloosheid gemeten over de beroepsbevolking, niet over de potentiële beroepsbevolking, omdat er immers lange tijd van werd uitgegaan dat de overigen, in casu de vrouwen, niet bij de beroepsbevolking hoorden. Het feit dat er nog steeds een conceptueel onderscheid bestaat tussen beroepsbevolking (of arbeidsaanbod) en potentiële beroepsbevolking, weerspiegelt de ervaren normaliteit van die naoorlogse huishoudensopbouw. Dit geldt eveneens voor andere belangrijke sociaal-economische concepten. Arbeidsproductiviteit wordt doorgaans gemeten naar rato van het aantal werknemers of het aantal gewerkte uren; als de gemiddelde arbeidsproductiviteit omlaag zou gaan doordat er veel relatief laagproductieve banen bijkomen (en de productie en dus het nationale inkomen hierdoor stijgt), wordt dit vaak als een teken van verslechtering gezien ${ }^{13}$. Zo ook worden de inkomensverdeling en de bewegingen van scheefheid en mobiliteit uitsluitend gerelateerd aan diegenen die een inkomen verdienen; degenen die dat (nog) niet doen worden niet meegeteld. Op tal van andere terreinen zijn er voorbeelden van deze exclusieve calculus te vinden.

Zolang de participatie aan de arbeidsmarkt inderdaad een aangelegenheid van huisvaders was, viel op deze calculus niet veel aan te merken. Met de grote sociaal-culturele veranderingen van de afgelopen decennia, alsmede de veranderingen die in de kwaliteit van de arbeid zelf zijn opgetreden, is de vanzelfsprekende basis echter aan deze concepten ontvallen. Al eerder heeft de Raad dit opgemerkt ten aanzien van de concepten werkloosheid en volledige werkgelegenheid 14 Toen stelde hij voor een 'inclusievere' term te gebruiken, die los stond van de vraag welk deel van de potentiële beroepsbevolking geacht werd te behoren tot het feitelijke arbeidsaanbod. Beter ware het - zo luidde toen het advies - voortaan vooral in termen van arbeidsparticipatie te spreken.

De analyse van hoofdstuk 2 heeft duidelijk gemaakt dat het overwegend 'exclusieve' vocabulaire waarin de sociaal-economische werkelijkheid wordt gegoten, een zelfstandige oorzaak is van vertekening van de werkelijkheid. Deze vertekeningen manifesteren zich als vormen van zowel naïef optimisme als naïef pessimisme. Zij worden echter zelden als zodanig herkend, omdat ze op feiten, data en officiële statistieken lijken te zijn geënt. Ook al is momenteel vooral het naïeve pessimisme een nadere bespreking waard, voor een goed begrip van de 'logica' daarvan is het nodig eerst de structuur van het naïeve optimisme uit te werken ${ }^{15}$.

Het gemakkelijkst gaat dit aan de hand van het begrip volledige werkgelegenheid. In de jaren zestig was de werkgelegenheid zo volledig dat de nieuwe banen door gastarbeiders moesten worden bemenst. Vanuit de overtuiging dat er in Nederland geen arbeidskracht meer te vinden was, werden grote groepen mensen uit de mediterrane landen hierheen gehaald. Natuurlijk had

13] Hans Blankert, 'Drieslag voor produktiviteit'; lezing gehouden bij de aanvaarding van het voorzitterschap van VNO-NCW, 3-6-1995; verschenen in Forum, 1-8-1995.

14] WRR, Een werkend perspectief; arbeidsporticipotie in de jaren '90; Rapporten aan de Regering nr. 38, 's-Gravenhage, Sdu Uitgeverij, 1990.

15] Hans P.M. Adriaansens, 'De calculus van de vergeten poedel'; in: Beleidswetenschop en Proktijk I; door Gerard Alberts (red.), Nijmegen, 1996, blz. 105-114. 
dit ook te maken met het soort banen, maar opvallend blijft dat de mogelijkheid van een hogere arbeidsparticipatie van vrouwen niet eens overwogen werd. Dit strookte immers niet met de bescherming ten opzichte van de arbeid die vanouds aan vrouwen werd geboden. Want dit was het sociaal-culturele fundament waarop de volledige werkgelegenheid van de jaren zestig was gebaseerd: vrouwen werden - letterlijk en figuurlijk - niet meegeteld. Als vrouwen toch tot de arbeidsmarkt toetraden, dan was dit veelal tijdelijk; bovendien was het normaal dat ze ook minder verdienden. Mannen daarentegen kregen een salaris waarin een kostwinnersvergoeding was verdisconteerd, ook als ze nog kostwinner moesten worden. Het minimumloon hield zelfs al rekening met twee kinderen. Het gevolg was dat de zogeheten volledige werkgelegenheid van de jaren zestig werd bereikt bij een arbeidsparticipatie die - voor wat betreft het percentage werkzame personen - niet hoger ligt dan thans ${ }^{16}$.

Blijkbaar hadden zowel wetenschap als beleid de formele inactiviteit van vrouwen zo volledig geaccepteerd dat ze niet konden bevroeden dat het ook anders kon. Het paradigmatische karakter van dit sociaal-culturele patroon wordt onderstreept door het feit dat ook de begrippen en categorieën waarin de sociaal-economische werkelijkheid werd gevangen, van deze sociaal-culturele vanzelfsprekendheid waren doortrokken. De werkgelegenheid was 'volledig' zolang de markt voor de mannelijke beroepsbevolking volledig werd geruimd. In de loop van de tijd is hierin wel wat verandering gekomen, maar nog steeds worden werkgelegenheid en werkloosheid gerelateerd aan het geregistreerde arbeidsaanbod. Het is dus nog alleszins normaal dat niet iedereen van de potentiële beroepsbevolking een plek op de arbeidsmarkt claimt.

In dit licht wordt ook veel van het sociaal-economisch beleid van de jaren zeventig en tachtig begrijpelijk. Het probleem van de tekortschietende werkgelegenheid werd opgelost door zoveel mogelijk potentiële werkers apart te zetten en voortaan niet mee te tellen. Door een deel van de sociale wetenschappers werd zelfs het einde van de arbeidssamenleving voorspeld 17. Vandaar dat nog steeds veel vrouwen niet worden meegeteld, dat arbeidsongeschiktheid lange tijd als een legitieme ontsnappingsroute werd gezien en dat ook langdurig werklozen van 57 jaar en ouder mochten worden afgeschreven. Een gevolg hiervan is dat het werkloosheidscijfer op dit moment niet zoveel zegt. Het bedraagt ongeveer een kwart van wat het zou bedragen als het niet als percentage van het geregistreerde arbeidsaanbod, maar als percentage van de potentiële beroepsbevolking zou worden uitgedrukt 18 . Hierbij moet dan wel worden bedacht dat als we deze 'inclusieve' calculus zouden toepassen op de periode van volledige werkgelegenheid, de werkloosheidscijfers van toen ongeveer even hoog zouden zijn uitgevallen.

In het licht van de huidige opvattingen weerspiegelen de volledige werkgelegenheid van de jaren zestig en de werkloosheidscijfers van thans dus vormen van naïef optimisme. Hetzelfde geldt voor de hoge arbeidsproductiviteitscijfers. Nederland is trots op zijn hoge arbeidsproductiviteit en concurreert op dit punt met de VS, Canada en Japan. Maar ook hier speelt de exclusieve calculus ons parten. Immers, de arbeidsproductiviteit wordt bij voorkeur gemeten per werkende. Hierdoor lijkt het uiteindelijk zelfs aantrekkelijk te worden om laag-productieve arbeid weg te saneren en mensen die alleen laag-productieve arbeid kunnen leveren met een uitkering buiten het gemiddelde arbeids-

16] Als alle vormen van formeel betaalde arbeidsparticipatie worden meegerekend, ook wanneer ze minder dan 12 uur per week betreft, is de arbeidsparticipatie thans zelfs enkele procentpunten hoger dan toen; in arbeidsjaren gemeten overigens niet.

17] Ten onzent bijv. Thoenes, Van Steenbergen en anderen; o.m. in A. Hogervorst e.a., Konsumptieverondering in maatschappelijk perspectief; WRR, Voorstudies en achtergronden nr. 10, 's-Gravenhage, Staatsuitgeverij, 1979.

18] OESO, Economic Survey. The Netherionds; Parijs, 1996, tabel 3, blz. 41. 
productiviteitscijfer te houden. Op die manier blijft dat cijfer hoog. Zou echter de arbeidsproductiviteit per hoofd van de bevolking worden berekend, dan resulteert een minder flatteus beeld. Vanuit de top vier zakt Nederland dan een flink aantal plaatsen op de OECD-ladder, zij het nu niet meer zo veel als enkele jaren geleden ${ }^{19}$.

Het conventionele beeld van de werkelijkheid, zoals weergegeven in statistische presentaties, brengt doorgaans dus een vertekening met zich mee. Helaas blijken wetenschap en beleid zich hiervan niet altijd voldoende rekenschap te geven. In de omstandigheden van vandaag leidt dit ertoe dat op zichzelf positieve of emancipatoire ontwikkelingen (zoals de groei van het aantal banen en inkomens) gemakkelijk de indruk vestigen van neergang en verwording. Het pessimisme dat hieruit spreekt, verdient dus de toevoeging naïef. Dergelijke vertekeningen kunnen aan de hand van de discussie over de inkomensverdeling worden toegelicht.

Regelmatig verschijnen er berichten dat de scheefheid van de inkomensverdeling is toegenomen en dat de inkomens in dit land verder uit elkaar zijn komen te liggen. Verwezen wordt dan naar de maatregelen die gedurende de laatste jaren in het kader van de sociale zekerheid zijn genomen; een verwijzing die ongetwijfeld correct is. Maar voor het grootste deel is de toename van de scheefheid in de inkomensverdeling het gevolg van een doorgaans als positief en emancipatoir gekenschetst verschijnsel: de toename van het aantal inkomenstrekkers. Omdat echter de categorie der nulverdieners in de exclusieve of uitsluitende inkomensverdeling niet bestaat, speelt ook de toestroom van nulverdieners naar de inkomensverdeling geen rol in de beoordeling van de verschuivingen binnen de inkomensverdeling. Als veel nulverdieners tot de inkomensverdeling toetreden - en zoals meestal het geval is, ergens onderaan beginnen -, wordt de inkomensverdeling per definitie schever. Hieruit te concluderen dat er sprake is van een anti-egalitaire beweging, is niet correct. Immers, waren de nulverdieners van stond af aan in de inkomensverdeling opgenomen, dan zouden juist de tegenovergestelde - egalitaire - tendenties aan het licht zijn gekomen.

Het verschijnsel dat zich hier voordoet, zou wel eens een belangrijke factor kunnen vormen in (de bestendiging van) het hedendaagse toekomstpessimisme ${ }^{20}$. Het komt erop neer dat een op zichzelf steeds inclusievere werkelijkheid wordt gemeten met een overwegend exclusief begrippenapparaat. Hierdoor wordt de indruk gewekt dat bewegingen naar grotere gelijk(matig)heid zoals emancipatiebewegingen nu eenmaal zijn, juist tot het tegenovergestelde resultaat leiden. De instroom van nieuwe verdieners leidt dan tot de suggestie van grotere ongelijkheid, de instroom van nieuwe beroepsbeoefenaars tot de suggestie van een lagere productiviteit, enzovoort.

Wanneer het beschikbare statistische materiaal op deze wijze wordt gebruikt, dan wordt de geleidelijke on thulling van een verborgen werkelijkheid voor een werkelijkheidsproces gehouden. Mensen gaan dan vinden dat er aan één stuk door arbeidsuitstoot plaatsvindt, maar hebben geen weet van de (grotere) arbeidsinstroom. Of zij menen dat de inkomensverdeling steeds schever wordt, terwijl zij zich niet realiseren dat dit verband houdt met de enorme groei van het aantal inkomenstrekkers. Het wonderlijke van dit alles is dat juist het afscheid van de exclusieve calculus bij velen voor het eerst de suggestie van uitsluiting lijkt op te roepen; daarvoor was de situatie - objectief bezien - wellicht nijpender, maar was men zich er niet of minder van bewust. 
Goede wetenschap is wetenschap die zich bewust is van de sociaal-culturele context waarin haar begrippen tot stand komen. Dat geldt a fortiori voor de gamma-wetenschap. Haar context is onvermijdelijk een politieke context, vol van voornemens, plannen, ideologieën en taboes. Als een Baron von Münchhausen die zich aan zijn eigen haren uit het moeras trekt, moet zij die context bestuderen met instrumenten die onvermijdelijk door diezelfde context zijn getekend. De kunst van de gamma-wetenschap ligt er dus in een verantwoorde balans van distantie en nabijheid te realiseren. De concepten, vragen en antwoorden die de sociale wetenschappen typeren, zijn onderdeel van hetzelfde historisch proces dat met behulp van die concepten, vragen en antwoorden moet worden bestudeerd. Wetenschap is net als beleid in de stroom der geschiedenis opgenomen.

In de wetenschappen die zich richten op (de geschiedenis van) mens en maatschappij moeten concepten heuristische waarde hebben. Een probleem is hierbij dat de stroom der geschiedenis geen definitief houvast biedt, geen archimedisch punt van waaruit adequate en bestendige kennis kan worden verkregen van mens en maatschappij. Er zijn immers vele gezichtspunten die relevante kennis kunnen opleveren. Dit hangt niet alleen af van de kwaliteit van het gezichtspunt, maar evenzeer van de vraag naar welke kennis we nu eigenlijk op zoek zijn. Als we inzicht willen hebben in het verloop van de Nederlandse kustlijn, dan moeten we niet langs het strand gaan lopen, maar kunnen we beter een vliegtuig huren. Vanuit een vliegtuig kunnen we evenwel weer niets zeggen over de vervuiling van het kustwater of de zeewerende kwaliteit van de duinen. Wie geinteresseerd is in het verhaal van de religieuze en politieke verzuiling van Nederland of de lotgevallen van een bijstandsmoeder met twee jonge kinderen, zit op tien kilometer hoogte te ver weg. Dit wil niet zeggen dat we altijd overal met de neus bovenop moeten zitten. Over de maatschappelijke consequenties van de verzuiling hebben we zeker niet alles verteld als we ons beperken tot participerende observatie in kerkgenootschappen. Over de bijstand zijn we nog lang niet uitgesproken als we alleen het verhaal van de betrokkenen hebben verteld. Wetenschap heeft dus bij voortduring te maken met de vraag naar het evenwicht tussen distantie en nabijheid, en steeds wordt aan dat evenwicht een andere invulling gegeven, afhankelijk van de vraag wat we nu eigenlijk willen weten, wat voor soort kennis we willen verwerven en wat we vervolgens met die kennis zouden willen doen.

De boodschap die bovenstaande formulering met zich brengt, is tweeledig. Allereerst moet duidelijk zijn dat de wetenschappelijke methode geen andere functie heeft dan de verbeeldingskracht te ondersteunen. Dit te erkennen maakt het bovendien mogelijk te begrijpen dat de onderzoeksmethode en de concepten die hierbij worden gebruikt, soms zó slecht zijn gaan passen bij het onderzoeksobject, dat ze de productie van relevante kennis eerder in de weg staan dan bevorderen.

Tegelijkertijd moet duidelijk zijn dat zonder concepten de werkelijkheid van mens, cultuur en maatschappij een gesloten boek blijft. Het is dan ook zaak de concepten die we ter bestudering van mens en maatschappij gebruiken, voortdurend te beoordelen op hun zoekkracht of heuristische waarde en ons te blijven realiseren dat die concepten in de meest letterlijke zin van het woord relatief zijn. Het grote gevaar van de institutionalisering van (gamma)wetenschap is dat haar concepten en andere wetenschappelijke instrumenten vaak te lang gebonden blijven aan een sociaal-culturele context die zelf al is achterhaald. Natuurlijk is er niets anders mogelijk dan het wetenschappelijk zoekproces te institutionaliseren. Bovendien zou zonder een dergelijke structurering waarschijnlijk in het geheel geen relevant onderzoek 
tot stand komen. Niettemin blijft het zaak in de wetenschap mechanismen in te bouwen die bestaande concepten bij voortduring op de proef kunnen stellen. In dit verband kan meer accent op toekomstonderzoek van belang zijn, omdat vooral daar de gebruikelijke instrumenten en de vanzelfsprekende concepten van beleid tegen het licht worden gehouden. In het toekomstonderzoek worden we geconfronteerd met de mythes van het heden, eerder nog dan in de empirische beschouwing alleen ${ }^{21}$. Daarom is het jammer dat de op zichzelf nuttige en noodzakelijke empirische oriëntatie van het wetenschapsbedrijf zo eenzijdig naar heden en verleden wijst. Aanvulling met een toekomstgerichte, meer teleologische en/of functionalistische beschouwing waarin de interactie van feiten en opvattingen een hoofdrol speelt, zou de voor de verbeeldingskracht noodzakelijke balans van distantie en nabijheid dichterbij kunnen brengen.

\subsubsection{Conclusie}

Als er al een les schuilt in bovenstaande beschouwing, dan is dit niet de les van het relativisme. De gedachte dat de begrippen waarmee we de werkelijkheid vangen seinsverbunden zijn, betekent nog niet dat anything goes. De les is wel dat elke historische periode haar eigen sociaal-culturele werkelijkheid met zich draagt; dat die sociaal-culturele werkelijkheid in opvattingen en concepten wordt gevangen; en dat de institutionalisering van dergelijke opvattingen en concepten na verloop van tijd kan leiden tot fricties tussen feitelijke ontwikkelingen en waargenomen werkelijkheid. Het betekent ook dat veel discussies over 'goed' of 'fout' niet alleen een paradigmatische vertekening in zich bergen maar tevens door de tijd kunnen verglijden. Politieke en morele meningsvorming is een poging om fundamentele opvattingen met betrekking tot menselijkheid, rechtvaardigheid en solidariteit zeitgemäsz of tijdsadequaat vorm te geven. Niet zelden wordt hierbij de concrete vorm of institutionalisering voor de dieper liggende waarde of het fundamentelere principe gehouden. Zo lijkt het in retrospect vanzelfsprekend dat kolonialisme of apartheid tot de morele categorie 'fout' behoren, maar in de sociaal-culturele werkelijkheid van het begin van deze eeuw konden zij ook worden beschouwd als adequate invullingen van centraal gekoesterde - ook nu nog aangehangen waarden. Hetzelfde geldt voor opvattingen met betrekking tot de huishoudensvorming en in het bijzonder met betrekking tot de rol van de vrouw en de plaats van de kostwinner. De normaliteit van een voorbije periode wordt te gemakkelijk door de protagonisten van een nieuwe tijd als 'fout' en discriminatoir bestempeld, net zoals de groeiende normaliteit van die nieuwe periode voor de verdedigers van het bestaande slechts moreel verval kan inhouden, zonder dat in feite over de achterliggende waarden verschil van mening bestaat 22 .

Om de concepten te vinden waarin het heden adequaat kan worden gevangen, is het nodig de toekomst 'bij elkaar te denken'. Zoals een verblijf in het buitenland zicht biedt op de sociale en culturele eigenaardigheden van het eigen land, zo biedt een toekomstverkenning de mogelijkheid na te denken over de vraag of de geïnstitutionaliseerde concepten en praktijken van wetenschap en beleid nog wel in staat zijn om de eigentijdse werkelijkheid boven tafel te krijgen.

${ }^{21}$ C Cf. I.J. Schoonenboom, Tussen Utopie en Dystopie; oratie, Wageningen, 21 juni 1990. Hier wordt het begrip 'toekomstbeeld' neergezet als een geheel van impliciete, vanzelfsprekende verwachtingen, die vaak zo vanzelfsprekend zijn dat ze het zicht ontnemen op afwijkende empirische ontwikkelingen. Toekomstonderzoek kan dan bevrijdend of verbredend werken.

22] Een voorbeeld daarvan levert het rapport van het Strategisch Beraad van het CDA. Het maakt zo'n zelfde gedachtengang niet slechts in de titel duidelijk (Nieuwe wegen, vaste waarden), maar beproeft tevens een uitwerking op sociaal-economisch terrein en in het bijzonder dat van de sociale zekerheid. Zie CDA, Nieuwe wegen, vaste waarden; aanzet tot strategisch beraad binnen het CDA; Den Haag, CDA, 1995.

23] SCP (1996), op. cit. 
In het voorgaande is betoogd dat ten minste een deel van de discrepantie tussen de sombere toekomstverwachtingen van een groot deel van de Nederlandse bevolking ${ }^{23}$ en de naar huidige inzichten zeker niet ongunstige vooruitzichten die de vaderlandse economie lijkt te bieden voor de sociale samenhang van de nabije toekomst, verklaard kan worden uit de inadequaatheid van de concepten waarmee die werkelijkheid in beeld wordt gebracht. Daarmee werd overigens niet betoogd dat de andere, 'inclusieve', manier van kijken wèl de volledige waarheid boven tafel kan brengen. Juist in de confrontatie van die twee manieren van kijken kan duidelijk worden welke interacties van feiten en opvattingen zich thans en wellicht ook in de toekomst voordoen. Een ongeclausuleerd oordeel over de aan- of afwezigheid van tweedeling, nu of in de toekomst, past daar niet bij.

\subsection{De emancipatie van de arbeid}

De fricties die zich zowel in sociaal-economisch als in sociaal-cultureel opzicht hebben voorgedaan gedurende de afgelopen twee decennia, markeren naar het oordeel van de Raad een belangrijke verandering, die wellicht zelfs als paradigmawisseling kan worden aangemerkt. In een periode van twintig jaar wordt in het publieke discours de ene vanzelfsprekende manier van denken en doen (i.e. paradigma) langzaam door een andere vervangen. Dat het hier om wezenlijk iets anders gaat dan om een gewone verschuiving op het spectrum van politieke opvattingen (bijv. van sociaal-democratisch naar neo-liberaal), kan worden afgelezen uit de omstandigheid dat alle belangrijke politieke groeperingen met de opeenvolging van die paradigma's worstelen. Om de aard van deze paradigmawisseling in beeld te brengen èn om de betekenis ervan voor de onmiddellijke toekomst scherp te krijgen, is het nodig die over elkaar schuivende paradigma's te typeren. Dit wordt hieronder gedaan via een korte geschiedenis van (de emancipatie van) de arbeid.

\subsection{Het beschermingsparadigma}

De ontwikkeling èn het succes van de verzorgingsstaat zijn gebaseerd op de gedachte dat het sociale leven beschermd moet worden tegen de ongelimiteerde dynamiek van de economische productie. In extreme vorm werd zelfs de verhouding tussen de beide domeinen van maatschappelijke organisatie, het sociale en het economische, als tegenstelling opgevat, getuige de steeds terugkerende waarschuwing dat de 'leefwereld' door 'het systeem' gekoloniseerd dreigde te worden ${ }^{24}$, dat de 'Gemeinschaft' door de 'Gesellschaft' werd ondergesneeuwd ${ }^{25}$, of dat de 'substantiële rationaliteit' door de 'functionele rationaliteit' werd opzijgeduwd ${ }^{26}$. De werkzaamheid van politiek en maatschappijwetenschap bestond er voor een groot deel in deze tegenstelling te verzachten. De verzorgingsstaat werd binnen dat paradigma als de ultieme overbrugging geduid. Het concept of de filosofie achter de verzorgingsstaat is er daarmee een van bescherming: bescherming van het sociale ten opzichte van de aberraties van het economische. De vraagstellingen en oplossingsrichtingen van wetenschap en politiek zijn in hoge mate door dit paradigma gekleurd.

Dit beschermingsparadigma vindt zijn oorsprong in de overgang naar het industriële tijdperk. In het laatste kwart van de negentiende eeuw kon de

24] Cf. J. Habermas, Theorie des kommunikativen Hondelns; 198।. In het Nederlands vertaald en bewerkt: H. Kunneman, Habermos' theorie van het communicatieve handelen; Meppel, Boom, 1983.

25] Cf. F. Tönnies, Gemeinschafi und Gesellschaft, Abhandlung des Communismus und des Socialismus als empririscher Culturformen; Leipzig, 1887.

26] Cf. Karl Mannheim, Man and society in an age of reconstruction; studies in modern social structure; London, Routledge and Kegan Paul, 1940; Anton C. Zijderveld, The Abstract Society; a cultural analysis of our time; New York. Doubleday, Garden City, 1970. 
tegenstelling tussen de eisen van de toenmalige economische productie enerzijds en elementaire vormen van sociaal welbevinden anderzijds maar weinigen ontgaan. De theorieën van Karl Marx en de romans van Charles Dickens spreken wat dit betreft boekdelen. Geen wonder dan ook dat de eerste resultaten van de poging om deze tegenstelling draaglijk te maken, te vinden zijn in de sfeer van het arbeidsrecht.

De manier waarop bescherming werd geboden, bestond erin de staatsmacht te vergroten ten opzichte van de markt, aanvankelijk nog vooral via de publieke steun aan organisaties van het particulier initiatief, maar uiteindelijk voor een groot deel door overheidsorganisaties zelf. De staatstaak ontgroeide hiermee de sfeer van ordening alleen; de staat ging op tal van domeinen ook zelf presteren. De sociale staat is een aanduiding voor een staat die op het vlak van het sociale tot presteren gehouden is. De tegenstelling tussen staat en markt of tussen plan en markt ging zo een wezenlijk onderdeel van het beschermingsparadigma vormen.

Het kan niet genoeg worden benadrukt dat het succes van dit paradigma groot is geweest. De Nederlandse verzorgingsstaat werd wijd en zijd geprezen. Maar zagen we in de voorgaande paragraaf al dat enkelvoudige concepten door de stroom der geschiedenis werden ingehaald, hier doet zich iets dergelijks voor met een complex systeem van opvattingen en regelingen. De beschermingsfilosofie en de constructies die eruit voortkwamen (samen het beschermingsparadigma vormend), gingen steeds minder goed passen bij de nieuwere ontwikkelingen in de economie en het sociaal-culturele domein.

\subsubsection{Van vervreemding naar ontplooiing}

Wat waren dan die ontwikkelingen? Voorop stond de geleidelijke verandering in de economische productie. In hoofdstuk 2 is er al op gewezen dat in de loop van deze eeuw het aandeel van de industriële en agriculturele sectoren in het totaal van de economische productie steeds kleiner is geworden. In plaats van deze primaire en secundaire sectoren waren het de tertiaire en quartaire sectoren (zeg maar: private en publieke dienstverlening) die het leeuwendeel gingen uitmaken van het bruto nationaal product. Dit geldt zo mogelijk nog sterker voor de werkgelegenheid. Hierdoor voltrok zich een majeure verandering in de aard en kwaliteit van een steeds groter deel van de arbeid. De 'energie-intensieve' aard van veel industriële arbeid maakte geleidelijk plaats voor een veel 'kennis-intensiever' en 'zorg-intensiever' 27 accent in de modernere vormen van (formele) arbeid. Arbeid begon de intrinsieke vervreemding die zo kenmerkend was voor de (pre-)industriële periode, langzaam te verliezen, en groeide uit tot een wezenlijk onderdeel van de eigen persoonlijke leefwereld ${ }^{28}$. Hiermee leidde de ontwikkeling van de economische productie tot een eerste bres in het fundament van het tegenstellings- of beschermingsparadigma: naar de mate dat arbeid zelf mensen ging 'beschermen' (tot ontplooiing brengen, zelfverwerkelijking mogelijk maken, enz.), nam de noodzaak af om mensen tegen arbeid in bescherming te nemen.

In samenhang met deze kwalitatieve ontwikkeling van de economische productie viel op sociaal en cultureel vlak een ontwikkeling waar te nemen in de richting van grotere mondigheid, individuele zelfstandigheid en zelfredzaamheid. Emancipatiebewegingen liepen volgens eenzelfde - en in dit verband

${ }^{27}$ Zie onder meer Robert B. Reich. The work of nations; preparing ourselves for 2 / st century capitalism; London. Simon and Schuster. 1993.

28] In dit verband zou de conceptuele trits van Hannah Arendt in The Human Condition (labor, work and action) goede diensten kunnen bewijzen. Cf. H. Arendt, The Human Condition; a study of the central dilemma's facing modern man; Garden City, N.Y., Anchor books, 1959. 
saillant - stramien: ze attackeerden de traditionele arrangementen die hen tegen arbeid moesten beschermen en gingen ze zien als instrumenten van maatschappelijke uitsluiting. Dit gold voor vrouwen in de jaren zeventig, voor allochtonen in de jaren tachtig en voor ouderen in de jaren negentig. Let wel, in al die gevallen waren het dezelfde arrangementen in de socialezekerheidssfeer die enkele decennia eerder ter bescherming waren opgezet en die nu als discriminatoir van de hand werden gewezen. Individualisering betekende eerst en vooral de groeiende behoefte om deel te hebben aan als wezenlijk ervaren maatschappelijke processen, niet via een plaatsvervanger of kostwinner, maar vooral ook zelf. De enorme groei van het arbeidsaanbod in de jaren zeventig, tachtig en negentig valt immers niet alleen uit noodzaak te verklaren. Dat de kwaliteitsverandering van arbeid hierbij een aanzuigende rol heeft gespeeld, is wel duidelijk.

Door deze dubbele beweging voldoet de beschermingsfilosofie steeds minder als grondslag voor een moderne samenleving. De fricties die van die groeiende discrepantie het gevolg zijn, worden evenwel niet altijd als zodanig herkend. Opvallend is dat wordt geprobeerd dergelijke fricties met de oude partijpolitieke epitheta te benoemen. Dit is niet alleen niet correct, maar leidt er bovendien toe dat ook de concrete maatregelen die worden voorgesteld of genomen binnen de oude schema's blijven ${ }^{29}$.

Zoals de reikwijdte van het beschermingsparadigma zich uitstrekte over een veelheid van levensdomeinen, zo beperkt ook de afnemende adequaatheid ervan zich niet tot het terrein van de arbeid zelf. Het geldt bijvoorbeeld ook voor het terrein van de sociale zekerheid, waar steeds meer wordt onderkend dat de vorm die het zekerheidsstelsel heeft aangenomen weliswaar ten minste een minimuminkomen garandeert, maar tegelijk tot maatschappelijke uitsluiting leidt en uiteindelijk ook niveau en duur van uitkeringen in gevaar brengt. De bescherming van degenen die het echt nodig hebben, werd zo in gevaar gebracht. De geleidelijke verandering van opvatting loopt dan ook parallel aan de introductie van een nieuw element in de grondslag voor de sociale zekerheid, namelijk het participatie-element. Was het voorheen zo dat de sociale zekerheid vooral inkomen garandeerde en weinig tot geen specifieke maatregelen inhield die terugkeer naar de arbeidsmarkt konden bevorderen, vanaf het einde van de jaren tachtig werd steeds meer nadruk gelegd op het activerende - 'springplank' - effect dat van de sociale zekerheid zou moeten uitgaan ${ }^{30}$. Dit accent kwam evenwel gemakkelijk in conflict met traditionele opvattingen over de zuiverheid (of, in termen van de voorgaande paragraaf: de exclusiviteit) van de arbeidsmarkt. Opvattingen over concurrentievervalsing, over 'kunstbanen', enzovoort onderstrepen de exclusiviteit van de arbeidsmarkt. Deze discussie is nog steeds niet afgesloten en vertegenwoordigt een dilemma dat binnen het beschermingsparadigma niet werkelijk kan worden opgelost ${ }^{31}$.

Ook op tal van andere levensdomeinen doen zich dergelijke dilemma's voor. Het gaat niet aan al die dilemma's uitvoerig in het licht van de tanende invloed van het beschermingsparadigma te bespreken. Volstaan wordt met de vaststelling dat op het terrein van de cultuur, het onderwijs en vele andere terreinen die vanouds tegen de gevaren van de economische productie in bescherming genomen moesten worden, soortgelijke fricties kunnen worden

29] Vgl. de discussie over de 'kerntaken van de overheid en de eendimensionaliteit van het concept 'terugtredende overheid'; zie de binnenkort door de WRR te publiceren studie over kerntaken van de overheid.

30] Vgl. WRR, Activerend orbeidsmorktbeleid; Rapporten aan de Regering nr. 33, 's-Gravenhage, Sdu Uitgeverij, 1987; en WRR, Een werkend perspectief, op. cit.

${ }^{31}$ ] Vgl. de discussie over de Melkert-banen e.d., bijv. in Bestuursforum, maart 1995; Binnenlands Bestuur, 29-1 1-1996; Intermediair, 10-5-1996 en 13-9-1996; FEM, 8-6-1996; Vrij Nederiand, 16-11-1996. 
onderkend. In het jargon van dit tijdsgewricht heet het dan dat markt(conforme) principes aan invloed winnen en overheidsinterventies naar de achtergrond dringen. Op het terrein van de staatstaak zijn de fricties en dilemma's wellicht nog het meest voelbaar. Toch begint ook in de discussie over de omvang van de staatstaken langzamerhand het idee post te vatten dat staat en markt zich niet als communicerende vaten tot elkaar verhouden. Ook daar is in steeds mindere mate sprake van nulsomdenken (waardoor een sterke overheid tot een zwakke markt leidt en een sterke markt een zwakke overheid veronderstelt) maar juist van synergie (waardoor alleen een sterke overheid voor een krachtige en dynamische markt kan zorgen).

Dit alles mag natuurlijk niet zo worden begrepen dat bescherming door middel van arrangementen van de verzorgingsstaat is achterhaald. De verzorgingsstaat diende aanvankelijk als correctie op de scherpe kanten van een ongebreidelde economische ontwikkeling: zeer lange arbeidstijden, kinderarbeid, gevaarlijke arbeidsomstandigheden, enzovoort. Later werd inkomensbescherming steeds belangrijker. Het succes van de verzorgingsstaat mag dan gelegen zijn in het feit dat op al deze punten grote verbeteringen zijn opgetreden, dit betekent nog niet dat dergelijke beschermingsarrangementen overbodig zijn geworden. Evenmin is het zo, dat deelname aan moderne vormen van arbeid voor iedereen vooral ontplooiing betekent. Zowel vanwege de immanente eigenschappen van de te ondernemen arbeid als vanwege de arbeidsverhoudingen zullen er ook in de toekomst banen blijven die in kwaliteit achterblijven. Bescherming en begeleiding zullen dan ook nodig blijven. Dit alles neemt niet weg dat de deelname aan formele arbeid thans meer dan ooit, en voor meer mensen dan ooit, beschouwd kan worden als een belangrijke kans op maatschappelijke deelname en integratie.

\subsubsection{Het participatieparadigma}

Als arbeid niet langer vooral als een verschijnsel moet worden gezien waartegen mensen in bescherming moeten worden genomen, maar ook steeds meer kan worden opgevat als 'beschermer' of 'ontplooier', raakt de complexe institutionele structuur, die op het oude principe van bescherming is geënt, geleidelijk achterhaald. Dit uit zich het meest pregnant in de discussie over participatie en uitsluiting ${ }^{32}$. De geijkte vormen van bescherming oriënteerden zich vooral op inkomensbescherming, ongetwijfeld vanuit de impliciete opvatting dat met een redelijk inkomen de maatschappelijke betrokkenheid van uitkeringsgerechtigden in stand zou kunnen blijven. Nederland had tenslotte een lange traditie van geaccepteerde (formele) inactiviteit, en het was dus niet vreemd dat het sociale stelsel dat in de jaren vijftig en zestig werd opgebouwd, hier als vanzelf aansluiting bij zocht. Bovendien betrof de arbeidsuitstoot toen vooral het type werk dat langzamerhand als minderwaardig werd gezien; een uitkering kon in sommige gevallen dan ook als een verdiende beloning voor jarenlang hard werken worden beschouwd. Door een uitgebreid stelsel van vrijwilligerswerk waren er voorts mogelijkheden genoeg om bij de maatschappij betrokken te blijven.

Door verschillende ontwikkelingen werd dit beeld echter verstoord. Toen ook in de hogere regionen werkloosheid om zich heen ging grijpen, was het met de gedachte dat niet-werken vooral 'genieten' van een uitkering betrof, snel gedaan. De algèmene opvatting luidt tegenwoordig dat het missen van de mogelijkheid om aan de centrale processen van de samenleving deel te nemen - en arbeid heeft binnen het geheel van die processen inmiddels een sleutelpositie verworven - tot uitsluiting en achterstelling leidt. De geijkte vormen

32] Cf. Symposia en conferenties over dit onderwerp, zie overzicht van congressen in: Nieuwsbrief Sociale Zekerheid; 's-Gravenhage, VUGA. 
van bescherming zijn dus tekort gaan schieten. Men ging zich in zijn ontwikkelingsmogelijkheden geschaad voelen, omdat de kansen ergens anders opnieuw een baan te vinden, kleiner werden en de relatieve hoogte van de uitkering steeds meer te wensen overliet. De uitkering werd een afkoopsom, temeer daar verschillende van de activiteiten die verricht zouden moeten worden om zich opnieuw voor de arbeidsmarkt te kwalificeren, aan uitkeringsgerechtigden verboden waren. Dat zou immers concurrentievervalsing impliceren en de posities in gevaar brengen van degenen die zich nog wel op de arbeidsmarkt bewogen. In die omstandigheid ontwikkelden zich tal van fenomenen die alleen vanuit de verkokering van het overheidsbudget enigermate te begrijpen waren, zoals de anomalie van leraren die òf werkloos waren òf overwerkt, een tekort aan zorg ondanks grote werkloosheid in de verpleging. Deze anomalieën toonden eens te meer aan dat de incongruente vormgeving van het economische en het sociale stelsel in de ogen van steeds meer slachtoffers tot grote onrechtvaardigheden aanleiding gaf. In ieder geval creëerde ze meer problemen dan ze kon oplossen.

Inmiddels hebben deze eigenaardigheden het besef aangewakkerd dat er toch manieren moeten zijn om de tegenstelling van het economische en het sociale te relativeren en - helemaal in overeenstemming met de emancipatie van de arbeid - ruimte te laten voor een parallelschakeling van beide. Dit is niet alleen maar een wens. Zoiets gebeurt reeds wanneer de traditionele opponenten - werkgevers en werknemers - gezamenlijk ondernemerschap gaan bevorderen vanuit de gedeelde overtuiging dat alleen op die manier werkgelegenheid en economische dynamiek kan worden begunstigd. Het gebeurt wanneer werkgevers en werknemers samen gaan zoeken naar mogelijkheden voor nieuwe banen tussen de laagste loonschalen van de CAO's en het wettelijk minimumloon. Het gebeurt wanneer werknemersorganisaties op zoek gaan naar mogelijkheden om de steeds flexibeler vormen van economische productie niet meer alleen als schending van de waardigheid te beschouwen, maar ze tegelijk proberen in te passen in een nieuw stelsel van employability en flexecurity. En het gebeurt ook wanneer iets wat eigenlijk niet binnen het paradigma mag worden toegestaan (bijverdienen in de bijstand, werken met uitkeringsgeld, studeren van een uitkering, enz.) min of meer officieel wordt gedoogd omdat de eigenlijke beleidslijn in het licht van een nieuwe participatiefilosofie kennelijk onredelijk is geworden. Het mooiste voorbeeld van de effecten van deze paradigmawisseling - van bescherming naar participatie - is evenwel te vinden in de net begonnen discussie over de inrichting van de sociale zekerheid.

\subsubsection{Naar een inclusieve arbeidsmarkt en een inclusieve sociale zekerheid}

Ook al lijkt de kwantitatieve ontwikkeling van de arbeidsmarkt voor de middellange termijn enige verlichting te bieden voor het stelsel van sociale zekerheid ${ }^{33}$, dit is nog geen reden om niet juist aan de onderkant van de arbeidsmarkt met extra maatregelen te komen. Het socialezekerheidsstelsel speelt hierin een belangrijke rol. In het voorgaande is betoogd dat wanneer een steeds zwaarder accent komt te liggen op arbeid als centrale vorm van maatschappelijke participatie, de ontoegankelijkheid van de arbeidsmarkt voor laaggeschoolden tot een serieuze bron van maatschappelijke ontwrichting zal kunnen uitgroeien. De in dit verband te nemen maatregelen kunnen niet los worden gezien van de inrichting van het stelsel van sociale zekerheid èn de verkokering van de overheidsbureaucratie. Die maatregelen zullen ertoe moeten leiden dat de door het huidige socialezekerheidsstelsel zelf opgeroepen uitschakeling van eenvoudig werk niet alleen een halt wordt toegeroepen, maar ook wordt omgekeerd. Hiervoor is nodig dat het participatieprincipe serieus 
wordt geïmplementeerd en dat het - overvloedige - werk in banen wordt georganiseerd. 'Ontschotting' van departementale begrotingen zou hierbij helpen. Waar bijvoorbeeld het leeuwendeel van de voorziene stijging van de kosten van de gezondheidszorg te maken heeft met de kosten van care (i.e. zorg) en niet zozeer met cure, valt niet in te zien waarom veel van de gedwongen (en via uitkeringen en kostwinnersvergoedingen toch betaalde) inactiviteit niet ook in die sector kan worden ingezet. Hetzelfde geldt voor tal van andere vormen van zorgintensieve dienstverlening, zoals het onderwijs, waarin de positieve effecten van professionalisering begrensd worden door een te grote en langdurige veronachtzaming van het belang van een kleinschalige - en dus arbeidsintensieve - vormingscontext ${ }^{34}$.

Twee veelgehoorde en met elkaar samenhangende vormen van kritiek op de participatiefilosofie mogen hier niet onbesproken blijven. De eerste betreft het verwijt dat de emancipatie van arbeid wellicht in de hogere regionen van de arbeidsmarkt heeft toegeslagen, maar dat zich juist aan de onderkant van de arbeidsmarkt nog veel soorten werk bevinden waartegen ook nu nog mensen nadrukkelijk in bescherming moeten worden genomen. Het tweede verwijt luidt dat er nu eenmaal te weinig werk is en dat alleen daardoor al de accentuering van arbeidsdeelname tot grotere frustratie moet leiden.

Inderdaad is het zo dat zich aan de onderkant van de arbeidsmarkt nog veel 'ongeëmancipeerd' werk bevindt. Het 'tegenargument', dat veel van dat oninteressante werk door velen interessanter wordt gevonden dan de onvrijwillige werkloosheid, mag dan niet van waarheid ontbloot zijn, maar overtuigt toch niet echt. Belangrijker is in dit verband de vaststelling dat de zorgintensivering van de economische productie ${ }^{35}$ vanaf een gegeven moment niet meer door de formele arbeidsmarkt kon worden opgenomen. Terwijl de twintigste eeuwse arbeidsmarkt in haar eerste 75 jaar juist een enorme toename van dienst- en zorgverlenende activiteiten en banen te zien heeft gegeven, is het proces van incorporatie van zorgtaken in de formele arbeidsmarkt in het laatste kwart van de eeuw gestagneerd. Dit heeft zeker niet te maken met een eventuele afname in de maatschappelijke behoefte aan zorg, maar vooral met de wijze waarop de verzorgingsstaat zichzelf met zijn eigen regelingen voor de voeten is gaan lopen. De toenemende vraag naar zorg maakt het in de toekomst weer mogelijk om van de incorporatie van zorgtaken in de formele arbeidsmarkt niet alleen de sociale, maar ook de economische baten op juiste waarde te schatten.

Dit brengt ons onmiddellijk op het tweede verwijt, dat er niet genoeg werk is voor laaggeschoolden. Het is goed hier te refereren aan de zogeheten 'Wet van Baumol'. Volgens Baumol bestaat er een duidelijk en structureel onderscheid tussen sectoren in productiviteitsgroei ${ }^{36}$. In sectoren waarin technologische ontwikkeling en investeringen een cruciale rol spelen, kan arbeid relatief gemakkelijk worden vervangen door andere productiefactoren. Hierdoor kan de productiviteit van de resterende arbeid snel stijgen. Het gaat hierbij met name om sectoren die blootgesteld staan aan buitenlandse concurrentie, zoals landbouw, industrie en bepaalde dienstensectoren. Hiertegenover staan sectoren, waarin dergelijke mogelijkheden op de korte of middellange termijn

34] Vgl. Staatssecretaris Netelenbos, 'Groepsgrootte in het basisonderwijs'; Tweede Kamer 1996/1997, 25065; Advies commissieVan Eyndhoven, Groepsgrootte in het onderwijs; Tweede Kamer 1996/1997, 25065, 22 oktober 1996. Voorts Ministerie van Onderwijs, Cultuur en Wetenschappen, Moatregelen ter bestrijding van wachtgelders (participatiefonds); Tweede Kamer 1996/1997, 25000 VIII, (Begroting OCW) blz. 105, 106, 211, 212.

35] Cf. Robert B. Reich, op. cit.

36] Zie W. Baumol, 'Macroeconomics of Unbalanced Growth: The Anatomy of Urban Crisis'; American Economic Review, vol. 57, 1967, blz. 415-426. 
niet of nauwelijks voorhanden zijn, zoals de quartaire sector ${ }^{37}$ : onderwijs, maatschappelijke zorg, delen van de gezondheidszorg, toezicht en dergelijke. Het gevolg is dat loonstijgingen in de eerste groep relatief gemakkelijk kunnen worden betaald uit productiviteitsverbeteringen, maar dat de tweede groep zich geconfronteerd ziet met de noodzaak om bij een geringe stijging van de productiviteit de prijzen te verhogen dan wel naar andere oplossingen te zoeken. Daarenboven geldt dat de vraag naar producten uit die tweede groep een hoge inkomenselasticiteit laat zien: naarmate het inkomen toeneemt, neemt ook de vraag naar deze producten relatief toe.

Beide ontwikkelingen, een achterblijvende productiviteitsontwikkeling en een hoge inkomenselasticiteit, resulteren in een stijgend aandeel van deze activiteiten in het bruto nationaal product en in de werkgelegenheid. Waar deze activiteiten in een land als Nederland veelal via collectieve uitgaven gefinancierd werden, verhoogden ze de collectieve lasten. Op basis van de bestaande maatschappelijke vraag en maatschappelijke waardering had dit ook niet problematisch hoeven te zijn.

Deze collectieve uitgaven stegen echter niet alleen voor deze (dienst- en zorgverlenende) activiteiten, maar nog sterker ten behoeve van de uitgaven in het kader van de sociale zekerheid. De hoge mate van non-participatie vertaalde zich in een hoge uitgaven- en premiedruk. In de afgelopen jaren zijn dan ook tal van maatregelen genomen, onder meer om de uitgaven voor de collectief gefinancierde laagproductieve activiteiten terug te brengen: door verlaging van de loonkosten - hetzij via een achterblijvende loonontwikkeling van ambtenaren en trendvolgers, hetzij via gesubsidieerde vormen van arbeid (JWG, banenpool, Melkertbanen) -; door invoering dan wel verhoging van verschillende eigen bijdragen; door privatisering van de uitvoering van allerlei wetten en regelingen; en door vermindering van het volume van deze laagproductieve productie ${ }^{38}$. De ervaring heeft geleerd dat de eerste optie, die van een divergerende loonontwikkeling, langzamerhand is uitgewerkt. Zo moesten in de gezondheidszorg de salarissen tussentijds weer worden verhoogd. De tweede en de derde optie zorgen weliswaar voor lagere collectieve uitgaven, maar niet voor lagere totale uitgaven voor deze producten. En nu is ook de vierde optie steeds meer onder druk komen te staan. De opvallende omslag die zich in september/oktober 1996. voltrok bij de discussie over de klassengrootte in het basisonderwijs spreekt voor zich. Blijkbaar accepteert men de daling in kwaliteit die hiervan het gevolg is, niet meer. Ook andere signalen - discussies over schaalvergroting in onderwijs en gezondheidszorg, de conducteur weer terug op de tram -, duiden erop dat mensen een steeds groter discrepantie ervaren tussen wat zij aan kwaliteit en kwantiteit verwachten en wat er feitelijk wordt aangeboden. Velen blijken die discrepantie te hoog te vinden.

Hieruit zou men kunnen afleiden dat mensen ook bereid zijn de bij goede voorzieningen behorende lasten te betalen. Tot nu toe is een zuivere discussie hierover echter niet mogelijk geweest, mede doordat alle collectieve uitgaven op een hoop werden gegooid en voorstanders van een verlaging van die uitgaven nauwelijks onderscheid maakten naar uitgavengroep. Toch zou deze discussie naar het oordeel van de Raad gevoerd moeten worden. De maatschappelijke

37] Naast inherente factoren, zoals hier benadrukt door Baumol, kan die achterblijvende productiviteitsontwikkeling ook veroorzaakt zijn door het gedrag van participanten in hec collectieve besluitvormingsproces. Hazeu onderscheidt vier mogelijkheden: afwezigheid van marktprikkels, wijze van besluitvorming, overdracht van 'productiviteitskneusjes', en de bijzondere positie van de overheid, waarbij kwaliteit de voorkeur krijgt boven productiviteit. Zie C.A. Hazeu, 'Het aanbod van collectieve voorzieningen'; Economisch-Stotistische Berichten, 1980, jrg. 65, blz. 16-21. Zelfs als men er in zou slagen het deficiënte gedrag van actoren op al deze punten weg te werken, dan nog geldt dat de productiviteitsontwikkeling in de quartaire sector structureel lager is dan in de eerstgenoemde sectoren.

38] Zie M. Wilke, 'De wet van Baumol en de collectieve lastendruk'; Economische-Statistische Berichten, 1996, jrg. 80, blz. 86-88. 
prijs die betaald is voor het terugdringen van het volume van de uitgaven, is immers meer dan de achteruitgang in kwaliteit en kwantiteit in dienstverlening. Ook de non-participatie van vooral de laaggeschoolden kan gezien worden als een uitvloeisel van dit beleid. Om nog zoveel mogelijk van het oorspronkelijke productaanbod overeind te houden, werden functies opgewaardeerd, waardoor lagergeschoolden nog eerder moesten verdwijnen. Binnen de gegeven kaders voltrok deze ontwikkeling zich volstrekt rationeel ${ }^{39}$. Bij constante, soms zelfs teruglopende, budgetten waren andere keuzen niet of nauwelijks mogelijk. De hier aangegeven gevolgen voor de samenleving werden niet in de afweging betrokken 40 .

Wordt deze afweging wel gemaakt, dan ontstaan andere perspectieven. Natuurlijk, waar mogelijk moet gestreefd worden naar productiviteitsverbetering, ook in de quartaire sector. Waar mogelijk moeten de collectieve uitgaven worden teruggebracht. Eerder is al naar voren gebracht dat de mogelijkheden hiertoe wel degelijk aanwezig zijn, gegeven de perspectieven op meer arbeidsparticipatie en de kansen op daling van de non-participatie. Maar tegelijk moet duidelijk zijn dat voor het behoud van bestaande en bovenal creatie van nieuwe werkgelegenheid in de quartaire sector, met veel meer baanmogelijkheden voor lagergeschoolden, wel een prijs zal moeten worden betaald. Het gaat dan om een arbeidsintensiever aanbod van quartaire diensten, van onderwijs tot plantsoenenonderhoud, van gezondheidszorg tot veiligheid op straat.

Het uitgangspunt dat een nieuw sociaal stelsel op geen enkele manier mag bijdragen aan uitsluiting van mensen uit het arbeidsproces, zal vroeger of later ook aanleiding kunnen geven tot een herformulering van de waarborgfunctie van de sociale zekerheid - of liever, van de via de sociale zekerheid te waarborgen of te verzekeren zaak ${ }^{41}$. Daarbij zal het onderscheid tussen de twee manieren waarop toegang tot de sociale zekerheid kan worden verkregen, namelijk via arbeidsvrijstelling dan wel onvrijwillige werkloosheid, worden aangescherpt. Beweging in deze richting is er overigens al; de grootschalige herkeuring van WAO-gevallen dient er juist toe om het onderscheid weer helder te krijgen tussen arbeidsongeschiktheid als vorm van arbeidsvrijstelling en onvrijwillige werkloosheid. Voor wat het eerste toegangscriterium betreft, zal er ook onder het participatieregime niets veranderen: de categorie arbeidsongeschiktheid zou via een arbeidsverlofregeling kunnen worden verbreed tot al die categorieën van wie om nader vast te stellen redenen (zwangerschap, verzorgingstaken, studie, ouderdom, enz.) niet wordt verwacht dat zij zelfstandig via arbeid in hun onderhoud moeten voorzien, maar die wel op het desbetreffende inkomen zijn aangewezen ${ }^{42}$. De waarborgfunctie is en blijft er in dit geval dus op gericht inkomen te verstrekken. Zet de participatiefilosofie door, dan zal in het geval van onvrijwillige werkloosheid de waarborgfunctie geleidelijk anders komen te liggen. Ook hiervan zijn de eerste tekenen onmiskenbaar aanwezig. Naarmate arbeid belangrijker wordt als instrument tot maatschappelijke participatie, zal voor al degenen die niet van arbeid zijn vrijgesteld (in de definitie van hierboven) de waarborgfunctie in eerste instantie het verwerven van een nieuwe plaats op de arbeidsmarkt gaan betreffen. Dat hiervoor (tijdelijk en/of gedeeltelijk) een uitkering noodzakelijk

39] Vergelijkbare processen deden zich ook in de particuliere sector voor. Zie WRR (1990), par. I.4.

${ }^{40}$ ] Zie in dat verband de recent verschenen notities betreffende de gevolgen van de afbraak van werkgelegenheid in Rotterdam en 's-Gravenhage, en de noodzaak hiervoor nieuwe werkgelegenheid te scheppen. Bijv. Naor een nieuw economisch klimaot: innovatiekracht en ondememerschop als sleutelfactoren in de Rotterdamse regio in de 2 le eeuw, Ontwikkelingsbedrijf en Havenbedrijf Rotterdam, 1996; en Discrepantie tussen vraog en aanbod op de arbeidsmarkt: Gemeente Den Haag, Dienst Sociale Zaken en Werkgelegenheidsprojecten, 1996.

${ }^{41}$ Cf. CDA, Nieuwe wegen, vaste waorden, op. cit.

12] Cf. Minister Melkert, 'Om de kwaliteit van arbeid en zorg: investeren in verlof(nota); Tweede Kamer 1994//995, 24 332, nr. 2; en VNO-NCW in samenwerking met NZF, Zorg in Bedrij; discussienata; Den Haag, 1995. 
is, spreekt vanzelf, maar zo'n uitkering zal meer dan thans in functie staan van een hernieuwde intrede in het arbeidsproces.

De geleidelijke introductie van het participatiebeginsel in de waarborgfunctie van de sociale zekerheid heeft vele, nog nauwelijks onderzochte, consequenties. De Raad hoopt hier binnenkort ten principale op in te gaan in een rapport over de toekomst van de sociale zekerheid. De ontwikkeling in de waarborgfunctie van de sociale zekerheid wordt daar in drie ideaaltypische modellen gevat. Daardoor kan een scherper zicht verkregen worden op de implicaties van die verschuiving èn op de niet altijd gemakkelijke politieke keuzen die met de implementatie van het relatief nieuwe participatieprincipe gepaard gaan.

\subsubsection{Conclusie}

Om de naar het zich laat aanzien gunstige ontwikkeling van de economie en de werkgelegenheid ook ten goede te laten komen aan de onderkant van zowel de scholings- als de arbeidsmarkt, is het noodzakelijk de consequentie te trekken uit de emancipatie van de arbeid en dus uit de verschuiving van een beschermings- naar een participatieparadigma. Door die verschuiving zijn de participatieve elementen van arbeid sterker op de voorgrond getreden dan de bedreigende elementen. Hiermee is arbeid thans in grotere mate dan voorheen geworden wat Durkheim al in 1893 voorzag: een wezenlijk element in de sociale samenhang van een geïndividualiseerde samenleving. De organisatie van de sociaal-economische orde zal juist dit aspect van arbeid serieus moeten nemen. Zij zal daaraan weinig mogelijk in de weg moeten leggen. De maatschappelijke druk op en de behoefte aan arbeidsdeelname, alsmede de erkenning dat verdere blokkades op dit punt tot de maatschappelijke uitsluiting leiden die ze juist hadden moeten voorkomen, zullen de komende decennia een belangrijke rol spelen bij de herinrichting van het sociale stelsel. Op het terrein van de sociale zekerheid zullen deze ontwikkelingen het meest markant tot uiting komen en ook moeten komen. Waar in hoofdstuk 2 kon worden geconstateerd dat vooral de hogere en middenregionen zullen profiteren van de te verwachten gunstige ontwikkeling van de werkgelegenheid, blijft naar het oordeel van de Raad derhalve een beleid noodzakelijk dat ook de onderkant van de scholings- en arbeidsmarkt openbreekt. Hierbij zou de door Baumol geuite gedachte dat zuiverder moet worden omgegaan met het begrip collectieve lasten, behulpzaam kunnen zijn. Een beleid dat deze noties verdisconteert, zou kunnen helpen een situatie te voorkomen waarin wèl de bovenkant van de arbeidsmarkt min of meer probleemloos wordt geruimd, maar aan de onderkant het stigma en de frustratie van onvrijwillige werkloosheid zou blijven bestaan of zelfs zou toenemen.

\subsection{De emancipatie van talent}

Hierboven werd als de kern van eventueel toenemende maatschappelijke spanningen het niet-aansluiten beschouwd van scholing en arbeidsmarkt in de lagere regionen. Voor de hogere en middenregionen werd voorzien dat relatief gunstige arbeidsmarktperspectieven er wel voor zouden zorgen dat het arbeidsaanbod daar zou worden geruimd, hetgeen tevens ruimte zou bieden voor een minder krampachtige verhouding onderwijs - arbeidsmarkt. Opleidingen zouden zich daar meer dan vroeger oriënteren op het aanbieden van een vormingscontext waarin leerlingen en studenten opgewassen raken tegen de snel veranderende kennisbehoeften van de maatschappij. 'Leren leren', 'platformkennis', 'analytisch vernuft', 'methodische diepgang' en 'communicatieve vaardigheid', vormen de uitdrukking van een beweging in het onderwijs die meer accent wil leggen op cognitieve vaardigheden dan op inhoudelijke kennisbestanden. Dit brengt met zich mee dat meer ruimte ontstaat voor vormen van niveaudifferentiatie, voor onderwijs op maat en dat 
binnen en wellicht ook tussen scholen niveauverschillen worden geaccepteerd. Een sterker meritocratisch accent blijkt zich op dit gebied reeds voorzichtig af te tekenen.

Hiermee is echter aan de onderkant van de scholingsmarkt nog geen (arbeidsmarkt)soelaas geboden. Integendeel, de combinatie van een sterker wordend meritocratisch accent in de samenleving als geheel met de afwezigheid van kansen aan de onderkant van de arbeidsmarkt, zou voor oplopende frustraties kunnen zorgen. Het probleem is immers dat op het niveau van de laaggeschooldheid niet voldoende banen bestaan. In de vorige paragraaf is beargumenteerd dat dergelijke banen mede door een te lang volgehouden beschermingsideologie en onder druk van de bezuinigingen als het ware kunstmatig van de arbeidsmarkt zijn verdwenen of weggehouden. Bovendien is gesteld dat een nieuw sociaalzekerheidsstelsel de consequenties moet trekken uit de 'nieuwe' participatie-ideologie, zodat dergelijke banen weer wel tot de arbeidsmarkt kunnen gaan behoren zonder dat een categorie van 'working poor' ontstaat zoals in de Verenigde Staten.

Voor een dergelijke ontwikkeling moeten veel weerstanden worden overwonnen, waarvan de belangrijkste diep wortelen in onze culturele traditie. Eén hiervan betreft de opvatting dat er laagwaardige banen bestaan, sommige zelfs zo laagwaardig dat mensen hiertegen moeten worden beschermd. Dit is veelal het geval bij werk waarvan de productiviteit te laag ligt om er het minimumloon voor te kunnen betalen. In dat geval wordt tot nu toe een antwoord op laaggeschooldheid gegeven door de betrokkenen te gaan beschermen of scholen. Een derde mogelijk antwoord, namelijk: laat de laaggeschoolde in zijn waarde en zorg dat hij zich via arbeid bij de maatschappij betrokken kan voelen, kan in het bestaande paradigma niet gemakkelijk worden gegeven en wordt met een verwijzing naar de onaantrekkelijkheid van banen aan de onderkant gemakkelijk in diskrediet gebracht. Berichten over de kennisintensivering van de economische productie lijken het bovendien nog lastiger te maken om een plaats vrij te houden voor mensen met een lage scholing. Toch is het niet onwaarschijnlijk dat de ontwikkelingen op dit vlak een richting zullen inslaan die de verhouding tussen menselijke waardigheid enerzijds en opleidings- en beroepsniveau anderzijds wezenlijk zullen veranderen. De groeiende behoefte om zowel aan de bovenkant als aan de onderkant van de arbeids- en scholingsmarkt extra kansen en extra ruimte te bieden, verplicht er als het ware toe de verholen verbinding van menselijke waardigheid met het niveau van de genoten opleiding of vervulde baan, (verder) los te laten. In dit verband betekent de 'emancipatie van talent' dus ook erkenning van de fundamentele gelijkheid van ieders menselijke waardigheid.

\subsection{Gelijkwaardigheid en onderwijs}

Onderwijs kwam vanaf de tweede helft van de jaren zestig duidelijk in het teken te staan van de Nederlandse aandacht voor sociale gelijkheid. Door onderwijskansen gelijkmatiger over de uiteenlopende sociale strata te verdelen, zou uiteindelijk de op herkomstverschillen gebaseerde sociale ongelijkheid gaan afnemen, zo werd gehoopt. Onderwijs werd aldus vooral een emancipatie-instrument. Onderwijsbeleid en onderwijswetenschap moesten bijdragen aan het verzachten van sociale ongelijkheid. Het talentenproject van Van Heek c.s. ging dus eerder over de emancipatie van groepen wier talent vanwege hun lage sociale herkomst niet tot ontwikkeling kon komen, 
dan over de emancipatie van talent ${ }^{43}$. Het bestreed de verdeling van onderwijskansen op basis van sociale herkomst, maar door de sociale gelijkheid voortaan zo sterk van onderwijskansen afhankelijk te maken, zou op termijn een nieuw probleem ontstaan. Waar de onderwijsvernieuwers van de jaren zestig en zeventig namelijk geen raad mee wisten, waren de nieuwe ongelijkheden die zouden ontstaan zodra de rol van sociale herkomst in onderwijskansen zou zijn teruggedrongen en talent onbeperkt tot ontplooiing zou kunnen komen. Er was dan weliswaar veel gewonnen, maar het probleem zou dan veranderen in 'gelijke kansen op ongelijkheid' 44.

Hiermee komen zowel de preoccupatie met als de gebrekkige realisering van sociale gelijkheid in een scherper licht te staan. Sociale gelijkheid moet kennelijk steeds opnieuw worden bewezen. Dat is niet alleen kenmerkend voor ons land, het geldt voor de meeste landen van West-Europa. Hierin ligt het grote verschil met de manier waarop in de Verenigde Staten met gelijkheid en gelijkwaardigheid wordt omgegaan. Gelijkwaardigheid is daar bovenal een axioma, niet iets wat voortdurend moet worden bewezen. Dit brengt met zich mee dat op tal van verdelingsdimensies de ongelijkheid er aanzienlijk groter is. De vaak enorme verschillen in rijkdom, opleiding enzovoorts komen paradoxalerwijs voort uit het belang dat aan het gelijkwaardigheidsaxioma wordt gehecht, waarvan meritocratie, concurrentie, vrije markt een passende uitdrukking schijnen te vormen. Juist het onbetwistbare karakter van menselijke gelijkwaardigheid doet in de VS de behoefte afnemen om sociale gelijkheid te beoordelen aan de hand van de uitkomsten van maatschappelijke (verdelings)processen.

Natuurlijk valt het ons moeilijk om op het punt van gelijkheid en gelijkwaardigheid lessen te trekken uit een systeem dat tot zulke grote verschillen tussen mensen leidt. Toch zijn er Europese auteurs geweest - en niet de minsten -, die in het contrast tussen de Europese en de Amerikaanse omgang met gelijkheid aspecten hebben ontdekt die een interessante aanvulling op ons gelijkheidsdenken kunnen bieden. Beroemd is de verwondering van die Franse heer van stand, Alexis de Tocqueville, toen hij de democratie van Amerika beschreef. Het contrast met het eigen post-revolutionaire Frankrijk doortrok zowel inhoud als toon van zijn beschrijvingen. Hij begint zijn reisverslag dan ook aldus:

'Il est un fait qui plus que tout le reste attire l'attention de l'Européen à son arrivée sur les rivages du noveau monde. Une égalité surprenante y règne parmi les fortunes; au premier abord les intelligences elles-mêmes semblent égales. Je fus frappé, comme les autres, à la vue de cette extrême égalité des conditions et je découvris sans peine l'influence prodigeuse qu'exerce ce premier fait sur la marche de la société; il donne à l'esprit public une certaine direction, un certain tour aux lois; aux gouvernants des maximes nouvelles, et des habitudes particulières aux gouvernés ${ }^{45}$.

43] F. van Heek, Het verborgen talent; Meppel, Boom, 1968; na aanvankelijke algemene instemming volgde kort daarop kritiek, onder meer dat Van Heek eenzijdig lette op de optimalisering van selectie binnen het bestaande hiërarchisch gelede onderwijssysteem zonder dat systeem zelf ter discussie te stellen. $\mathrm{Vgl}$. J.A. van Kemenade en J.A Kropman, 'Verborgen talenten? Kritische kantekeningen bij een onjuiste interpretatie'; Sociologische Gids, 1972, jrg. 19, blz. 219-228; en H. Harbers, 'Sociologie, staat en maatschappij, de rationaliteit van een driehoeksverhouding'; in: Saciologisch en antropologisch jaarboek; Deventer, Van Loghum Slaterus, 1987, blz. 203.

44] C. C.E. Vervoort, 'Onderwijs en beleid'; In: Gelijkheid en ongelijkheid in Nederland; analyse en beleid; door J. van den Doel en A. Hoogerwerf (red.), Alphen aan de Rijn, Samsom Uitgeverij, 1975, blz. 168.

45] Alexis de Tocqueville, De lo démocratie en Amerique, première edition historico-critique, revue et augmentée par $E$ Nolla; Tome I, Paris, Libraire philosophique J Vrin, 1990, Introduction, blz. 3 (oorspronkelijke manuscriptversie). 
Uit het citaat blijkt dat het Tocqueville gaat om de 'conditions des égalités'. Buiks, van wie ook de aanduiding 'heer van stand' stamt, licht dat toe met het volgende door hem vertaalde citaat van Tocqueville:

Om kort te gaan, zowel in Amerika als bij ons, worden de mensen in de loop van het sociale bestaan volgens bepaalde categorieën gerangschikt; de gemeenschappelijke gewoonten, de opleiding en vooral de rijkdom bepalen de classificatie; maar die regels zijn noch absoluut, noch onbuigzaam, noch permanent. Ze bepalen verschillen van voorbijgaande aard en vormen geen echte klassen; ze geven geen enkele mens enige superioriteit, zelfs niet qua opinie, boven de ander, zodat hoewel die twee individuen elkaar nooit in dezelfde salons zien, als ze elkaar in het openbaar ontmoeten, de een de ander ziet zonder hoogmoed, en de ander de een bekijkt zonder te glunderen. Uiteindelijk voelen zij zich gelijk en dat zijn ze ook'. ${ }^{46}$

In de minstens even scherpe Amerikaanse waarnemingen van Johan Huizinga ontwaren we eenzelfde contrast. Zo vraagt hij zich aan het begin van zijn bekende studie Mensch en meenigte in Amerika waarom het hem niet lukt een scherper beeld te krijgen van Amerika. Hij geeft dan vervolgens als antwoord dat zijn begrippenapparaat is ontleend aan de oude wereld met zijn oude tegenstellingen, bijvoorbeeld die van traditie tegenover vernieuwing, standaardisatie tegenover differentiatie, individualisme tegenover collectivisme, ontplooiing tegenover dwang ${ }^{47}$. Huizinga beklemtoont dat zaken die elkaar vanuit Europees gezichtspunt lijken uit te sluiten, elkaar in Amerika juist veronderstellen en bovendien wederzijds versterken ${ }^{48}$.

In zulke vergelijkingen van het avondland met de anti-aristocratische democratie van Amerika valt telkens weer op dat ons egalitarisme zich richt op de resultaten van het maatschappelijk proces. Als deze maar niet tezeer uiteenlopen, is bewezen dat de rol van sociale herkomst (of van intelligentie, onderwijs of geslacht) verwaarloosbaar klein is geworden. Sociale herkomst is daarmee niet verdwenen als onderscheidingscriterium; het speelt integendeel juist een belangrijke rol in zoverre als moet worden gepoogd mensen van een nederiger sociale herkomst gelijke maatschappelijke kansen te geven. Ons egalitarisme beoogt de resultaten van het maatschappelijke verdelingsproces binnen een zekere bandbreedte te houden en ziet beperktheid van de bandbreedte als bewijs van de gelijkwaardigheid van mensen.

De discreditering van sociale herkomst als verschaffer van onderwijskansen heft derhalve niet de resultaatoriëntatie op, die in de Nederlandse definitie van sociale ongelijkheid ligt besloten. Alleen is de fakkel nu overgenomen door intellectuele vaardigheid of cognitieve competentie. In toenemende mate lijken dit de criteria te worden aan de hand waarvan sociale ongelijkheid wordt gelaagd. Met deze nieuwe bedreiging van het gelijkheidsideaal wordt vooralsnog onhandig omgegaan. Enerzijds is de overwinning op het criterium van sociale herkomst niet te versmaden, anderzijds mag het nieuwe criterium van intellectuele competentie niet te hoog worden opgespeeld, omdat ook dan sociale ongelijkheid weer het resultaat is. Dit leidt tot tal van compromissen die steeds het midden houden tussen twee bewegingen: de afkeer van vormen van onderwijs die degenen met de meeste talenten optimaal begeleiden èn de

46] P.E.J Buiks, Alexis de Tocqueville en de democratische revolutie; een cultuursociologische interpretatie; Assen, Van Gorcum, 1979. blz. 59-60. In het vervolg van zijn betoog wijst Buiks erop dat Tocqueville een ideaaltypische werkwijze hanteerde en dat het hem niet ging om de verschijningsvorm van een concreet verschijnsel, maar om het 'pure (of 'ideale') type hiervan'. |bid. blz. 147-151.

77 J. Huizinga, 'Mensch en Meenigte in Amerika'; opgenomen in: Verzamelde werken; Haarlem, H.D. Tjeenk Willink en Zn, 1950 , blz. 251.

48] Ook voor de meer recente periode zijn er vele auteurs die - impliciet of expliciet - het bedoelde contrast als uitgangspunt nemen van hun uiteenzettingen. 
onrealistische behoefte om elke laaggeschoolde eindeloos verder te scholen. De bandbreedte mag immers niet te groot worden. Men zou in dit verband van de Procrustes-these kunnen spreken, die verklaart waarom, ondanks de enorme expansie van het hoger onderwijs in ons land, het plafond van dat onderwijs gedurende de jaren zeventig en tachtig eerder omlaag is gegaan dan omhoog 49. Deze these zou mede de enorme vlucht kunnen verklaren die het speciaal onderwijs in diezelfde periode heeft genomen, de efficiency-maatregelen, de grote fusiebewegingen, de studieduurverkorting, de gemeenschappelijkheid van allerlei regelingen, de gewogen loting bij studierichtingen waar een numerus fixus bestaat, enzovoort.

De confrontatie met de Amerikaanse variant van egalitarisme zou de gelegenheid kunnen bieden een volgende stap te zetten in het talentenproject van weleer. In dit vervolg op het talentenproject zou het niet meer moeten gaan om de realisering van gelijke onderwijskansen voor mensen van uiteenlopende sociale herkomst, maar om de emancipatie van talent in zijn geheel. Het streven zou hierbij dus zijn elk talent op zijn eigen merites te bezien en naar de mate van het mogelijke tot ontwikkeling te brengen. Een dergelijke beweging begint zich momenteel voorzichtig te manifesteren zowel aan de onderkant als aan de bovenkant van de talentenverdeling. Onderwijs gaat geleidelijk weer gezien worden als 'het koesteren van talent', ongeacht de vraag of dat talent nu hoog of laag op de intellectuele ladder scoort en ongeacht de vraag hoe sterk hiermee de bandbreedte van resultaten wordt opgerekt. Voor het eerst sinds jaren wordt openlijk gesproken over de manier waarop met toptalent moet worden omgegaan en tegelijkertijd groeit de erkenning dat ook laaggeschoolden de kans moeten hebben zich op de arbeidsmarkt te weren. Hier is sprake van een centrifugale beweging die als vanzelf de traditionele resultaatgerichte opvatting over sociale gelijkheid onder druk zet. Dit roept de vraag op hoe hiermee moet worden omgegaan.

De beweging in de richting van een grotere bandbreedte valt te rechtvaardigen indien en voorzover er voor degenen aan de onderkant van de opleidingsverdeling een volwaardige plaats in de samenleving beschikbaar komt. Een meritocratie die voorbijgaat aan de verdiensten van lagergeschoolden zou in onze cultuur van sociale gelijkheid worden beschouwd als een ongelukkige erfopvolger binnen de traditie waarmee juist had moeten worden afgerekend. De enige mogelijkheid in dit opzicht ligt in de ongeclausuleerde erkenning van menselijke waardigheid als het fundament van sociale gelijkheid, zonder dus die waardigheid te koppelen aan of afhankelijk te maken van andere elementen zoals sociale herkomst of intellectuele potentie. Het blote feit dat hierin een mogelijkheid ligt, betekent natuurlijk nog niet dat die mogelijkheid ook zal worden benut. Dergelijke teleologische redeneringen zijn in het tijdperk van empirische wetenschap in diskrediet geraakt. Toch kan de feitelijke ontwikkeling in een richting van grotere ongelijkheid van resultaten alleen worden gelegitimeerd door een ideologie die 's mensen gelijkheid en gelijkwaardigheid niet (alleen) meer hoeft te bewijzen, maar ze (ook) als axioma neemt. Dàt er door de veranderende omstandigheden behoefte aan zo'n legitimering zal ontstaan, staat buiten kijf. Of die er ook zo uit zal zien als hier wordt gesuggereerd, is een tweede. Gegeven het erfgoed van onze verzorgingsstaat, is hopelijk aan te nemen dat - anders dan bijvoorbeeld in de Verenigde Staten de variatiebreedte van resultaten nooit een als humaan bestempelde grens zal kunnen onderschrijden. 
Een van de consequenties van een lijn van denken als hiervoor aangegeven is dat ook de laaggeschoolde in zijn waarde kan worden gelaten zonder hem de druk van verdere scholing op te leggen. Lange tijd is de enige manier om laaggeschoolden tegemoet te treden geweest, hen tot meer scholing aan te zetten, dan wel hen uit te sluiten van deelname aan het arbeidsproces. Door allerlei beschouwingen over de kennisintensivering van de samenleving werd deze neiging nog versterkt: volwaardig meedoen zou immers alleen mogelijk zijn bij een steeds hoger minimum aan intellectuele competentie. Al eerder is gezegd dat deze nadruk op kennisintensivering tot eenzijdigheden leidt. Naast kennisintensivering van de economische productie is ook de zorgintensivering ervan een zo mogelijk nog opvallender karakteristiek van de emancipatie van de arbeid.

In dit verband is er al vaker op gewezen dat juist in de zorgintensieve sectoren van de samenleving de behoefte aan formele inzet aanmerkelijk groter is dan wat de arbeidsmarkt op het ogenblik aan vacatures te bieden heeft. De omvang van het vrijwilligerswerk vormt hiervan sinds jaar en dag het bewijs. Juist in de sterk geprofessionaliseerde sectoren van dienstverlening, zoals het onderwijs en de gezondheidszorg, is de behoefte aan arbeidskrachten groot en de formele mogelijkheid om mensen in dienst te nemen gering. Dit heeft een zichzelf versterkend effect: de desbetreffende zorg of dienst wordt meer dan nodig is beoordeeld op grootschalige efficiency en minder op kleinschalige 'context'. Vandaar dat de overwegend kleinschalige context van het vrijwilligerswerk op het punt van betrokkenheid, warmte en emotionaliteit zo gunstig afsteekt tegen de overwegend anonieme en bureaucratische structuur van professionele en 'betaalde' zorg. Vandaar ook dat hetzelfde type arbeid dat in het vrijwilligerscircuit als nobel Florence Nightingale-werk wordt beschouwd, eenmaal opgenomen in het formele of professionele circuit (waarvoor overigens Florence Nightingale de grondslagen legde) als 'laagwaardig' of zelfs als onwaardige 'hamburgerbaan' wordt beschouwd. De sterk overdreven tegenstelling tussen 'geld' en 'zin' van respectievelijk betaald werk en vrijwilligerswerk, is terug te voeren op deze zichzelf versterkende dynamiek.

$\mathrm{Al}$ eerder is er op gewezen dat het terrein van de quartaire dienstverlening vele mogelijkheden biedt om uitkeringen in betaalde banen om te zetten en dat zulks de maatschappij als geheel ten goede zou komen, maar tevens juist aan de onderkant van de scholingsmarkt soelaas zou bieden. Afsplitsing van functies, mede gericht op het bieden van weliswaar professioneel gestuurde maar kleinschalige vormings- en zorgcontexten, zou zowel in onderwijs als gezondheidszorg voor aanmerkelijke kwaliteitsverbetering kunnen zorgen. De vele miljoenen ${ }^{50}$ die hiermee gepaard gaan, zouden dan vanuit de begroting van Sociale Zaken en Werkgelegenheid moeten worden gefourneerd en betreffen voornamelijk een activering van uitkeringsgelden.

\subsubsection{Conclusie}

De emancipatie van talent is een beweging waarin feitelijke ontwikkelingen en verschuivingen van opvatting met elkaar interacteren. Met de voortgaande kennisintensivering van de samenleving en de economische productie dreigt het gevaar dat alleen aan de bovenkant van de talentenverdeling ruimte zou ontstaan. Hoewel op zichzelf van groot belang voor de dynamische ontwikkeling van de samenleving, is dit niet genoeg. Juist een kennisintensieve samenleving biedt pas een goed thuis, als de onderkant van de talentenverdeling bij die samenleving betrokken kan raken. De maatschappelijke emancipatie van 
talent in de hierboven bedoelde zin is daarom een belangrijke voorwaarde voor de integratie van nu veelal uitgesloten groepen en individuen. Of deze voorwaarde in de nabije toekomst zal worden vervuld, is natuurlijk niet zeker. Zou dit echter niet gebeuren, dan is de kans op maatschappelijke tweedeling navenant groter.

\subsection{De sociale samenhang van een geïndividualiseerde samenleving}

Veranderingen in de samenleving zijn van invloed op het debat over sociale cohesie. De druk op bestaande instituties neemt toe en de sociale cohesie kan een 'kwestie' worden. De reacties variëren doorgaans van tegenhouden, ontkennen en veroordelen van de veranderingen, gepaard aan het manhaftig overeind houden van bedreigde instituties, tot aan de poging om de desbetreffende instituties aan de nieuwe omstandigheden aan te passen, zonder rekening te houden met elementen die ook voor de toekomst nog waardevol zijn. De eerste reactie loopt in zijn uiterste consequentie het gevaar de vormen en instituties van het samenleven te verwarren met de diepere waarden die aan het samenleven ten grondslag liggen; de tweede reactie loopt het gevaar van opperste 'rekkelijkheid' in de interpretatie van de wezenlijke doeleinden van het samenleven. Bovendien is er in het laatste geval nog de extra moeilijkheid om de veranderingen goed te taxeren.

De socioloog Emile Durkheim heeft de veranderingen in de aard en vormgeving van sociale cohesie op klassieke wijze verwoord in zijn studie $D e$ la Division du Travail Social uit 1893. Hij betoogde dat de opkomende industriële samenleving niet alleen de oude vormen en instituties van sociale cohesie onder druk zette maar ook het startpunt vormde voor een ontwikkeling naar een nieuwe uitdrukkingsvorm voor sociale cohesie. Het 'cement' van die nieuwe samenleving - door hem de solidariteit genoemd - zou voortaan vooral 'organisch' van aard zijn. Hij wilde daarmee zeggen dat de ontwikkeling in de richting van differentiatie en verschil zoals die in de arbeidsverdeling tot gelding kwam, niet noodzakelijk tot verlies van sociale cohesie hoefde te leiden. Hij verzette zich tegen het sombere geluid dat (ook al) op het einde van de negentiende eeuw gehoord kon worden. Juist in de arbeidsverdeling tussen de verschillende onderdelen, individuen of 'organen' èn in de wederzijdse afhankelijkheid die daarvan het gevolg was, zouden voortaan de instituties groeien die voor samenhang in de samenleving zouden zorgen. Dit was anders dan in de pre-moderne samenleving, waarin niet de differentiatie van taken en individuen maar eerder hun groepsgewijze segmentatie voor de sociale samenhang zorgde. De verschillende segmenten van zo'n voor-moderne samenleving waren in wezenlijke aspecten aan elkaar gelijk. De sociale samenhang was juist geënt op de afwezigheid van differentiatie en specialisatie. In de moderne samenleving werd de autarkie van die segmenten afgebroken onder invloed van een grensoverschrijdend proces van differentiatie en specialisatie. Daarmee kwam de oude conscience collective in een centrifugale beweging terecht, waardoor zowel de relatieve autonomie van het individu werd beklemtoond als tegelijk ook dat individu in veel grotere - wellicht abstractere samenhangen werd opgenomen ${ }^{51}$. Deze paradox van individualisering en globalisering werd voor Durkheim het hart van de moderne 'solidariteit'.

51] Zie ook Johan Huizinga, Mensch en meenigte in Ameriko; op.cit. blz. 329: 'Het oude beeld van de maatschappij als een menselijk organisme, uitgedrukt in tal van mythische concepties, de grondslag van antieke en middeleeuwsche staatsbespiegeling, en nog verscholen onder de modernste sociologische gedachte, heeft een steeds treffender gelijkenis gekregen, sedert productie en verkeer de maatschappelijke functies aan die van een zenuw-en voedingssysteem gelijksoortig maakten. Maar naarmate de samenleving menschvormiger werd, werd daarin de functie van de mensch zelf gedegradeerd tot werktuigelijkheid. En toch voelt hij zich vrijer, meer meester van de stof, dan ooit tevoren'. 
Durkheim realiseerde zich heel goed dat deze omslag met de nodige problemen gepaard ging. Aberraties en onevenwichtigheden vormden dan ook de belangrijkste thematiek van zijn andere studies. In Le Suicide (1897) bijvoorbeeld, ging hij in op de condities waaronder het evenwicht van die nieuwe orde verstoord zou worden. Maar voorop bleef staan de erkenning dat de nieuwe industriële vorm van economische productie en de arbeidsverdeling die daarmee gepaard ging ook een nieuw soort maatschappelijke samenhang of solidariteit betekende en dat de gedachte dat automatisch alle samenhang door die nieuwe ontwikkelingen zou verdwijnen niet correct was.

Voor de huidige discussie over sociale uitsluiting en individualisering valt nog altijd veel van Durkheim te leren. Natuurlijk is er in de eeuw die ons van het werk van Durkheim scheidt, veel veranderd. Toch klinkt in de zich sterk doorzettende (arbeids)participatiefilosofie van dit moment de essentie door van Durkheims betoog: arbeid als instrument tot maatschappelijke integratie. Ook de paradox van toenemende individuele autonomie en de opname van datzelfde individu in steeds grotere en onpersoonlijkere systemen heeft in de discussie over maatschappelijke samenhang een hoge graad van actualiteit. De ontwikkelingen die sinds het einde van de Tweede Wereldoorlog de emancipatie van de arbeid hebben versneld, maken dat Durkheims vooruitziende blik nu door velen kan worden gedeeld. De emancipatie van de arbeid heeft ervoor gezorgd dat de participatiefilosofie zich via een sterk stijgend arbeidsaanbod steeds duidelijker ging manifesteren. De verwachting is, dat de nesteling van dit denken in de samenleving vooralsnog zal voortgaan. De ooit zo automatische koppeling van arbeid aan de wereld van hardship en labeur begint op haar einde te lopen. Daardoor zal maatschappelijke uitsluiting steeds nadrukkelijker in termen van arbeidsparticipatie kunnen worden geduid (d.w.z. zonder reminiscenties aan een 19e eeuws industrieel verleden) en zal de toenemende vraag naar een arbeidsmarktverruimend beleid de traditionele incongruenties tussen economie en sociaal stelsel verder doen verdwijnen. De voorgaande bijdragen over de emancipatie van de arbeid, de inclusieve sociale zekerheid en de emancipatie van talent en laaggeschooldheid onderstreepten deze toekomstverwachting. Eén aspect verdient hierbij echter nog aparte aandacht, namelijk de vraag of en in hoeverre een individualiserende samenleving een serieus niveau van solidariteit, van sociale cohesie kan bereiken.

\subsubsection{Individualisering en solidariteit}

Dat de politieke steun voor een herijking van de fundamenten van de verzorgingsstaat vooralsnog slechts aarzelend tot stand komt, is niet verrassend. Vrijwel alle partijen en 'partners' die op het nationaal-politieke en sociaal-economische vlak een rol spelen, zijn als vertegenwoordigers van relevante collectiva en categorieën ook zelf in de ooit zo succesvolle opbouw van de verzorgingsstaat geworteld. In eerste instantie lijkt men bij een herijking alleen maar te verliezen. De winst op lange termijn wordt niet of onvoldoende onderkend. Een nuchtere analyse van het proces van individualisering komt in zo'n context niet gemakkelijk op gang. Deze op zichzelf neutrale term is in de jaren tachtig dan ook in de politiek-morele profileringsstrijd terecht gekomen. Het gevolg hiervan was dat individualisering als een al dan niet nastrevenswaardige politieke doelstelling werd gezien, in plaats van als een empirisch waarneembaar verschijnsel, dat niet wordt teruggedrongen door het te veroordelen. Het is om deze reden dat eerst een paar misverstanden rond het begrip individualisering moeten worden opgehelderd.

Allereerst is er het misverstand dat het proces van individualisering de tegenpool vormt van solidariteit of sociale cohesie. Vanuit dat vertrekpunt wordt individualisering al vlug verantwoordelijk gesteld voor de 'erosie van het 
maatschappelijk middenveld' 52 . Individualisering wordt geassocieerd met het recht van de sterkste, met hedonisme, met fragmentering, met de onverbiddelijkheid van marktwerking, met de doorbreking van een overlegcultuur, kortom met alles wat aan de bestaande samenhang afbreuk deed. Individualisering wordt zo de bijl aan de wortel van de samenleving. Hierboven is aangegeven dat een dergelijke gedachtengang wel een heel specifieke vorm van individualisering en individualisme veronderstelt en dat achtereenvolgens Tocqueville, Durkheim en Huizinga gewezen hebben op een vorm van associatief individualisme dat zich wel degelijk met een hoge mate van solidariteit en sociale cohesie verdraagt. Recent heeft de Duitse socioloog Ulrich Beck een en ander nog eens in hedendaagse termen herhaald. Onder de veelzeggende titel Ohne Ich kein Wir ${ }^{53}$ verzette ook hij zich tegen de vanzelfsprekendheid waarmee individualisering als het tegendeel van een Sozialmoral wordt beschouwd.

Die Moral des eigenen Lebens bejaht, was öffentlich beklagt wird: ohne Ich kein Wir. Wir nur als selbstbestimmtes Wir, nicht als Vorgabe, nicht als Summe, nur als Zustimmung der Individuen. Die Ethik des eigenen Lebens leistet damit zunächst eine Kritik der herrschenden Wir-definition - Klasse, Stand, Familie, Geschlechtsrollen, Gemeinwohl, Partei, Nation und so weiter.

Om te kunnen begrijpen wat de nieuwe vorm van solidariteit inhoudt, moeten volgens Beck eerst twee misverstanden uit de weg worden geruimd: het marktmisverstand en het traditionalistische misverstand 54 . Beide suggereren een vereenzelviging van individualisering met egoïsme. Het marktmisverstand zet het nieuwe individu neer als een nutsmaximeerder, slechts uit op eigen gewin. Maar op die manier, zegt Beck, wordt autonomie met egoïsme verward:

Das eigene und globale Leben musz sich grenzübergreifend orientieren. Will es als eigenes Leben überleben, musz es sich Fremdes zu eigen machen. In einer Welt der Widersprüche musz der einzelne ein hohes Masz an Autonomie anstreben und herstellen. Autonomie bedeutet aber nicht Egoismus.(..) Es ist daher ein schwerwiegender Denkfehler, die Frage nach neuen Solidaritäten zu verwechseln mit der Frage, wie die Marktegoismen gezügelt, gezähmt, zusammengeschweiszt werden können. Diese Frage lautet vielmehr so: Wie kann man Autonomie, soziale Bindung, eigenes Leben und Verantwortung in einer sich selbst gefährdenden Zivilisation neu aufeinander abstimmen - und zwar in den verschiedenen Sphären des sozialen Lebens, einschlieszlich der Wirtschaft?

Het traditionalistische misverstand suggereert dat de teruggang in het lidmaatschap van allerlei traditionele organisaties eveneens als bewijs van egoïsme valt te duiden:

Man unterstellt ein Kriterium, zum Beispiel Mitgliedschaft in Parteien, Gewerkschaften und Kirchen. Die Flucht aus einer solchen Mitgliedschaft setzt man dann mit Egoismus gleich. Das ist pure Dogmatik, die herrschende Maszstäbe verabsolutiert. Jugendliche, beispielsweise, hassen Vereine. Sie sind aber für alles mögliche zu engagieren: für Umweltfragen sowieso, aber auch gegen Obdachlosigkeit, für Betreuung von Drogenabhängigen, Aids-Kranken und so weiter. Stünde heute Greenpeace zur Wahl, wohl über neunzig Prozent der Jugendlichen würden diese 'Partei' wählen.

52] H.P.M. Adriaansens en A.C. Zijderveld, Vrijwillig initiatief en de verzorgingsstoat, cultuursociologische analyse van een beleidsprobleem; Deventer, Van Loghum Slaterus, 1981.

53] Ulrich Beck, Die Zeit; Nr. 35, 23 August 1996, blz. 10 Politik

54] Zie voor soortgelijke misverstanden ook de 'rationeel calculerende' en 'traditionele gemeenschapsconceptie' in: WRR. Eigentijds Burgerschap; WRR-publicatie vervaardigd o.I.v. H.R. van Gunsteren, 's-Gravenhage, Sdu Uitgeverij, 1992, blz. $13-16$. 
Becks conclusie is duidelijk: individualisering sluit solidariteit en sociale cohesie niet uit, maar brengt juist een nieuwe vorm van solidariteit met zich mee, zolang niet krampachtig pogingen in het werk worden gesteld om de traditionele instituten en instituties als pars pro toto voor solidariteit te houden.

In deze zin verstaan is het individualiseringsproces zo oud als de westerse cultuurgeschiedenis: toen Paulus vaststelde dat je niet per se Jood hoefde te wezen om Christen te kunnen worden, was dat een weinig opgemerkte maar niettemin belangrijke individualiseringsstap: op die manier werden nationale en religieuze identiteit voor het eerst van elkaar losgekoppeld en kon je zowel Christen als Athener zijn. Die dubbele identiteit maakte mensen minder van één en hetzelfde collectief afhankelijk; de banden binnen de christelijke gemeenschap konden er losser door worden, er groeide een nieuwe vorm van solidariteit, abstracter en meer ruimte latend voor het individu. Als dat niet was gebeurd, dan zou het Christendom zich niet in die mate over de westerse wereld hebben kunnen verspreiden als het feitelijk heeft gedaan ${ }^{55}$. De godsdienstgeschiedenis kent overigens vele voorbeelden van individualisering. De Reformatie in de vijftiende en zestiende eeuw was opnieuw een duidelijke individualiseringssprong: hoe nietig ook, het individu kreeg een rechtstreekse lijn met God, zonder 'hemels baldakijn' 56 , zonder tussenkomst van engelen en priesters, zonder mogelijkheid om in een collectief weg te schuilen. Dat leidde tot nieuwe organisatievormen, tot andere vormen van solidariteit, en tot wat Max Weber heeft genoemd, een 'rationele religie' 57.

Het feit dat solidariteit individualiseert, wil dus niet zeggen dat de solidariteit verdwijnt. In de eerste plaats niet omdat deze individualisering alleen maar heeft kunnen plaatsvinden op basis van een steeds algemener kader van solidariteit, dat in de loop van de ontwikkeling van de verzorgingsstaat is ontstaan. Niet mag worden vergeten dat de verantwoordelijkheid van de overheid om de samenleving mogelijk te maken - bijvoorbeeld door de deelname aan arbeid te garanderen - een randvoorwaarde betekent voor solidariteit. In de tweede plaats houdt individualisering van de solidariteit niet in dat die nieuwe vormen van solidariteit zonder problemen tot stand zullen komen. Alleen al het feit dat ze niet meer 'voorgegeven' zijn, maar op basis van individuele verantwoordelijkheid tot stand komen, zorgt voor een geheel eigen problematiek, zoals uit de volgende paragraaf zal blijken.

Ook beleidsmatig zijn er consequenties verbonden aan deze begripsverheldering. Naar de mate dat het automatisme verdwijnt waarmee individualisering en solidariteit als tegengestelden worden opgevat, ontstaat ruimte voor een nieuwe invulling van sociaal cohesieve verbanden en arrangementen. In sociaal-economisch opzicht lijkt dat thans te gebeuren onder noemers zoals flexibilisering, flexecurity (als nieuwe combinatie van flexibilisering en zekerheid) en employability.

\subsubsection{Individualisering en de ont-categorisering van de samenleving}

In hoofdstuk 3 is betoogd dat het steeds moeilijker wordt de samenleving in categorieën in te delen. De traditionele zuilen hebben zich vanaf de jaren zeventig een proces van ontzuiling en secularisering moeten laten welgevallen. Ook al houdt nog een groot deel van het maatschappelijk middenveld de herinnering aan die periode in stand (het omroepbestel, de politieke partijen, de vakverenigingen, de organisaties in de zorgsector), dit neemt niet weg dat

55] Cf. A.D. Nock, St Poul; New York, Harper, 1938.

56] Peter Berger, The Socred Conopy; elements of a sociological theory of religion; Garden City, N.J.. Doubleday, 1967; in het Nederlands vertaald als 'Het Hemels Baldakijn'.

57 Max Weber, 'Die protestantische Ethik und der 'Geist' des Kapitalismus'; in: Gesommelte Aufsätze zur Religionssoziologie; Tübingen, Mohr, 1920.1921. 
de ideologische scherpte en de maatschappelijke organisatiekracht uit dit onderscheid is verdwenen. Daarmee verdween een in de wereld unieke vorm van maatschappelijke cohesie waarin de sterke verticale integratie per 'zuil' niet tot onhanteerbare maatschappelijke problemen leidde doordat aan de top van de zuilenconstructie geïstitutionaliseerd overleg plaatsvond 58 . Toen deze vorm van verticale integratie en cohesie onder invloed van ontkerkelijking en secularisering verdween, kwam het gewicht van de maatschappelijke organisatie steeds meer te liggen op vormen van horizontale integratie, dat wil zeggen in sociaal-economische lagen of 'klassen'. Ondanks het voortbestaan van de vele (neo-)corporatische voorzieningen die in de tijd van de verzuiling waren getroffen om uiteenlopende belangen op elkaar te binden (de publiekrechtelijke bedrijfsorganisatie), groeiden de jaren zeventig en tachtig uit tot de jaren van polarisatie. De sociaal-economische dimensie werd maatgevend voor de toewijzing van maatschappelijke solidariteit. Het organisatieleven, het maatschappelijk middenveld, paste zich hier geleidelijk bij aan.

In dit beeld van polarisatie en van boven- en ondergeschikte lagen of strata passen de emancipatiebewegingen van vrouwen, allochtonen en ouderen die in hoofdstuk 3 aan de orde zijn gesteld. Maar ook daar werd al geconstateerd dat een voortgaande benadering van emancipatievragen in termen van categorieën steeds minder perspectief biedt. Met de toetreding van vrouwen tot de arbeidsmarkt zijn weliswaar niet alle achterstandsproblemen van vrouwen verdwenen, maar deze hebben minder te maken met de categorie, dan met specifieke kenmerken die ook in andere bevolkingsgroepen tot achterstanden leiden, zoals laaggeschooldheid en gebrek aan werkervaring. Ditzelfde geldt voor de meeste andere categorieën. Het lijkt erop, dat inmiddels de preponderantie van het denken in (sociaal-economische) lagen, collectiva of categorieën op zijn retour is; dat er na de ontzuiling van de samenleving zich ook zoiets als een ontlaging begint af te tekenen. Vakverenigingen krijgen te maken met een steeds grotere 'onoverzichtelijkheid' van het economische productieproces. Ze hebben te kampen met sterk uiteenlopende en steeds flexibeler belangen. Het onderscheid tussen werknemer en ondernemer begint zijn scherpte uit de hoogtijdagen van de industrialisatie te verliezen. Politieke partijen onderscheiden zich steeds minder door hun overgeleverde politieke ideologie en op sociaal-economisch terrein lopen de tegenstellingen eerder door dan tussen de partijen. In sociaal-cultureel opzicht is de vanzelfsprekendheid van het kostwinners- of alleenverdienersgezin aan het afbrokkelen, waardoor ook dit tot voor kort onbetwistbare aanknopingspunt voor overheidsbeleid is verdwenen. De nieuwe onoverzichtelijkheid van huishoudensvormen en de enorme groei van aantal en soorten huishoudens maakt het voor een overheid steeds minder aantrekkelijk en ook minder mogelijk om op die 'markt' eigen normen te hanteren. In het algemeen zijn de voorspelbaarheid en de maakbaarheid die gepaard gingen met het leven in categorieën, geweken voor de onvoorspelbaarheid van een individu dat weliswaar volkomen is ingebed in tal van kleine en grote netwerken, maar zich in elk van die netwerken toenemend onafhankelijk is gaan opstellen.

Wat heeft dit alles te betekenen voor de onmiddellijke toekomst? Individualisering in de bovenbedoelde zin, dat wil zeggen: het op basis van toenemende individuele verantwoordelijkheid doorbreken van voorgevormde, verzuilde of gelaagde, organisaties en instituties, veronderstelt een ruimte waarin de oude instituties aan nieuwe omstandigheden kunnen worden aangepast, nieuwe verbindingen en associaties kunnen ontstaan. Nogmaals in de woorden van Ulrich Beck: 'Wir nur als selbstbestimmtes Wir, nicht als Vorgabe, nicht als Summe, nur als Zustimmung der Individuen.' Dit betekent dus dat in de toekomst opnieuw met nieuwe vormen van vrijwillig en 
particulier initiatief gerekend moet worden, zowel binnen als buiten het arbeidsbestel. In feite is die ontwikkeling reeds aan de gang.

Om een voorbeeld te geven uit het welzijnswerk: dit werk waarvoor met name in de negentiende eeuw de grondslagen zijn gelegd door enkele filantropisch ingestelde ondernemers en predikanten, toont zich de laatste jaren vaak inventiever dan traditioneel bureaucratische instellingen bij het vinden van passende methoden van arbeidsbemiddeling en bij samenwerking met het particuliere bedrijfsleven. Dat is echter niet altijd zo geweest. In zijn relatief korte bestaan heeft het welzijnswerk veel organisatiefasen doorgemaakt, waarbij het ook telkens een andere naam kreeg ('maatschappelijk hulpbetoon', 'maatschappelijk werk', 'sociale actie', 'welzijnswerk', 'sociale sectorwerk', enz. genoemd). In de eerste organisatiefase, vanaf het einde van de negentiende eeuw tot aan de jaren dertig, kreeg het bedoelde werk meer vaste vorm in kerkelijke diaconieën en in katholieke, protestantse en neutrale stichtingen en verenigingen. In de volgende fase, van de jaren dertig tot de jaren zeventig, verloor het vervolgens een deel van zijn louter lokale bindingen en kreeg het een meer landelijk karakter; dit kwam met name doordat het deel ging uitmaken van zuilen en bij de regering vertegenwoordigd werd met een eigen 'parlement', de Nationale Raad voor Maatschappelijk Werk. De derde fase is verbonden met de uitbouw van de verzorgingsstaat in de jaren zeventig; het werk werd toen voor 100 procent door het rijk gesubsidieerd 59 . De vierde fase, vanaf het begin van de jaren tachtig, wordt getekend door het regeringsbesluit - na de mislukking tot invoering van de Kaderwet Welzijnsbeleid - om het welzijnsbeleid af te stoten naar gemeenten en om het meer bloot te stellen aan marktkrachten en -ontwikkelingen. Op dit gebied lijkt het nu enig succes te hebben zodat men voorzichtig kan spreken van een herontdekking van welzijnswerk als particulier initiatief. Daarmee lijkt het werk, na de verenigings-, verzuilings-, en bureaucratische fase, weer terug bij waar het begon, namelijk bij het particuliere initiatief. Het verschil is wel dat de kring van potentiële initiatiefnemers nu ruimer is dan in de negentiende eeuw, dat het werk verder is geprofessionaliseerd en een betaalde functie is, en dat nu niet meer geestelijken maar eerder vertegenwoordigers van 'de cliënten' in de besturen van welzijnsinstellingen participeren.

De conclusie van herwaardering van particulier initiatief mag een vreemde conclusie lijken, haaks op de ervaringen in en rond de verzorgingsstaat. Sommigen zullen er zelfs nostalgie naar vervlogen tijden in vermoeden. Toch is dat niet correct. Het vrijwillige en particuliere initiatief van de toekomst zal minder voorgevormd zijn, minder van bovenaf geregisseerd dan in het naoorlogse tijdperk van verzuiling en polarisatie het geval was.

Maar ook al mag een dergelijke ontwikkeling voor de Nederlandse situatie betrekkelijk nieuw zijn, ook hier kent de cultuurgeschiedenis van het Westen een spraakmakend voorbeeld. Want toen de Engelse dissenters via Leiden naar Amerika trokken, namen ze een organisatiemodel met zich mee dat kenmerkend was voor de Anglicaanse Low Church, namelijk sterk congregationalistisch van aard. Het overwegend episcopaalse organisatiemodel, dat de Anglicaanse High Church gemeen had met de katholieke en Lutherse kerk, bleef kenmerkend voor vele organisatiepatronen op het vasteland van Europa. De enorme uitwaaiering van het Amerikaanse voluntarisme laat zien hoezeer dit congregationalistische model paste bij de individuele verantwoordelijkheid tot samenwerking. De autobiografie van Benjamin Franklin staat dan ook model voor de do-gooders die zich om tal van uiteenlopende redenen met elkaar verbonden 60 .

59] Met als onbedoeld gevolg dat het werk zijn eigen vraag ging creëren. Zie ook: $H$. Achterhuis, De markt van welzijn en geluk; een kritiek van de andragogie; Baarn, Ambo, 1980.

60] Benjamin Franklin, The Autobiography and other writings; New York, N.Y., 1961. 
Kortom: de geschiedenis van het Westen is in sociaal-cultureel opzicht een geschiedenis van individualisering van de solidariteit en van de globaliseringsmogelijkheden die daarmee gepaard gaan. Dat de huidige processen van individualisering opnieuw tot versterking van zowel afhankelijkheid als verantwoordelijkheid zullen leiden, lijdt geen twijfel. In het Amerika van eertijds hebben interpersoonlijke afhankelijkheid en verantwoordelijkheid zich vooral om godsdienst en kerk georganiseerd. Als de emancipatie van arbeid zich zal blijven voortzetten en arbeid daardoor meer dan ooit uitgroeit tot solidariteitsmechanisme, zou de arbeid zelf in de toekomst wel eens de as kunnen worden waaromheen individualisme en solidariteit vorm gaan krijgen. Wat dat te betekenen heeft voor allerlei andere levensterreinen, bijvoorbeeld die van de persoonlijke relaties, valt natuurlijk niet te voorzien. Bovendien zullen de effecten voor de komende twee decennia - de termijn waarover deze toekomstverkenning zich uitstrekt - in dit opzicht ongetwijfeld beperkt blijven.

\subsubsection{Individualisering, de rol van de overheid en de maatschappelijke organisaties}

Als de categorisering of collectivisering van solidariteit het moet afleggen tegen steeds individueler vormen van solidariteit en sociale cohesie, heeft dit - als gezegd - ook gevolgen voor de rol van de overheid. Het is niet overdreven in dit verband de roep om een 'terugtred van de overheid' of een beperking tot 'kerntaken' te memoreren. In het algemeen past zo'n patroon van groeiende individuele verantwoordelijkheid bij een overheid die de ruimte voor het invullen van die verantwoordelijkheid zo groot mogelijk maakt. Dit betekent dat het sterk interventionistische of presterende karakter van de overheid meer naar de achtergrond verdwijnt. Hiermee wordt de rol van de overheid overigen niet minder belangrijk. Het ordenende of randvoorwaardelijke optreden van de overheid zal er sterker door worden beklemtoond. Dat is dus ook iets anders dan de veelgehoorde opvatting dat een sterke overheid leidt tot een zwakke markt en een sterke markt tot een zwakke overheid; alsof het om een nulsom zou gaan, een vaste machtsruimte die tussen markt en overheid moet worden verdeeld 61 . Zo'n gedachte gaat voorbij aan het feit dat de machtsruimte voor markt en overheid gelijkelijk kan toenemen. Zo lopen de groei van de markt en de uitbreiding van de randvoorwaardelijkheid gelijk op. Anders gezegd: om het 'vrije spel der maatschappelijke krachten' de ruimte te geven, is juist een sterke ordenende overheid nodig. Markten, verenigingen en activiteiten van verantwoordelijke individuen (ondernemerschap) veronderstellen immers een kader van randvoorwaarden zonder welke ze niet zouden kunnen functioneren ${ }^{62}$.

Behalve op het thema van kerntaken kan ook worden gewezen op wat wel wordt genoemd de ontvlechting van de relaties tussen overheid en maatschappelijke belangenorganisaties. In de hoogtijdagen van verzuiling en corporatisme vervulde de overheid immers bij wijze van spreken de rol van 'Kroonlid' in het georganiseerd overleg. Zij verwierf daarbij prestatieve taken die afzonderlijke partijen elkaar niet toevertrouwden. Ook werd zij benaderd als het toporgaan dat 'de verdeelde nationale gemeenschap' bijeen kon houden. Vooral de verbreding van het kiesrecht in 1917 heeft, tezamen met de uitbreiding van socialezekerheidsarrangementen (en dus ook van de lasten voor het bedrijfsleven) in de ons omringende landen, met name GrootBrittannië, België en Duitsland, bijgedragen aan een soortgelijke uitbreiding

${ }^{61}$ ] The Economist sprak in 1995 in dit verband van de mythe van de machteloze staat. 'The myth of the powerless state'; The Economist, 7-10-1995, blz. 13-14.

62] Karl Polanyi, The great tronsformation; met inleiding door R.M. Mclver, Boston, Beacon Press, 1944. In dit boek laat Polanyi de samenhang zien tussen marktontwikkeling en ontwikkeling van randvoorwaarden. Hij doet dat aan de hand van de transformatie van de samenleving in de negentiende eeuw. 
van de overheidsrol in ons eigen land. De daarbij behorende toename van nationale wetgeving vergemakkelijkte vervolgens de nevenfunctie van de nationale overheid als platform en ontmoetingsplaats van de toppen van de zuilen; maatschappelijke belangen waren alom vertegenwoordigd in politieke partijen en parlement, in departementen (bijv. Landbouw) en in grote adviesraden; de grote voormannen van de zuilen waren tevens de partijleiders. Het corporatisme vanaf het eind van de jaren dertig (CAO-wetgeving, $\mathrm{PBO}$-wet, Organisatiewet Sociale Verzekeringen van 1952, Ziekenfondswet, uitbreiding Volkshuisvestingssector) institutionaliseerde het collectieve overleg vanaf het centrale niveau als top van de piramide tot aan het decentrale niveau als basis.

In tegenstelling tot wat sommigen in de jaren zeventig verwachtten, luidde de overgang van verzuiling naar polarisatie niet het einde in van veel corporatieve arrangementen ${ }^{63}$. Zo werd rondom 1980 de term neo-corporatisme gemunt om aan te geven dat er sprake was van een herleving van gezamenlijke besluitvorming door overheid, werkgevers en werknemers; nu opgevat als 'sociale partners' om hun onderlinge gelijkwaardigheid aan te geven 64 . Het 'Akkoord van Wassenaar' van 1982 geldt als voorbeeld van deze ontwikkeling. De werkelijke uitdaging van de traditionele corporatieve structuren kwam daarentegen pas aan het eind van de jaren tachtig met de individualisering en het verlangen om de belangen van staat en georganiseerd bedrijfsleven te ontvlechten. Dan ziet men ook een verandering in de functie van het centraal overleg - tot kader voor decentrale onderhandeling -; dan ook verandert de positie van de SER van een representatief orgaan naar een deskundigencollege; en bovendien verdwijnt dan - betrekkelijk onopgemerkt - het Landbouwschap, ooit het boegbeeld van het Nederlands corporatisme.

De genoemde ontvlechting speelt vooral op sociaal-economisch terrein en wordt daar verder bevorderd door de opkomst van de participatiefilosofie. Een uitvloeisel van die filosofie is dat sociale zekerheid meer wordt ingezet om de deelname aan arbeid te vergemakkelijken en zo nodig te bestendigen. Dit vereist een andere opstelling van de uitvoeringsorganen van de sociale zekerheid, zoals ook duidelijk werd door de parlementaire enquête daarnaar (commissieBuurmeijer, september 1993). Tegen deze achtergrond streeft de regering er thans naar monopolies in dienstverlening te doorbreken, wil zij meer werken met een concessiestelsel voor de aanbesteding van de uitvoeringsactiviteiten, en tracht zij zodanige randvoorwaarden te bewerkstelligen dat markten voor dienstverlening ontstaan. Bekende voorbeelden zijn de nieuwe markt voor arbeidsbemiddeling, waar uitzendbureaus en openbare arbeidsbemiddeling beide opereren, alsmede de recente voorstellen om iets soortgelijks mogelijk te maken voor de uitvoering van socialezekerheidsregelingen.

De vervlechting uit vervlogen tijden werd mogelijk gemaakt door het bestaan van een betrekkelijk hecht georganiseerd maatschappelijk draagvlak. Zoals aangegeven, zijn juist op dit punt grote veranderingen opgetreden door de individualisering. De gevolgen hiervan blijken ook op het politieke speelveld, waar coalities tot stand zijn gekomen die lange tijd voor onmogelijk werden gehouden. Het draagvlak van de overheid met zijn vaste scheidslijnen tussen de grote partijen en vaste coalitiepatronen lijkt vervangen door een veel minder overzichtelijk geheel van 'individuelle Zustimmung'. Welke partij met welke andere een coalitie kan aangaan, hangt af van die individuele toestemming achteraf; achteraf kan dan blijken of een partij de combinatie heeft geko-

63] WRR, De komende vijfentwintig joor; een toekomstverkenning, Rapporten aan de Regering nr. I5, 's-Gravenhage, Staatsuitgeverij, 1977, in het bijzonder hfdst. 3.

64] Cf. W.Albeda en M.D. Ten Hove. Neo-corporatisme, evolutie van een gedachte, verandering van een patroon; Kampen, Kok, 1986; en Anton Hemerijck, The historical contingencies of Dutch corporatism; Oxford, 1992 (hfdst. 8 e.v.). 
zen die de kiezers kunnen billijken. Er vindt aldus een overgang plaats van een voorgestructureerd draagvlak voor overheidshandelen naar een draagvlak dat veel meer afhankelijk is van individuele toestemming. Uitgedrukt in zijn uiterste gevolgen: autonome burgers 'voteren' de ruimte aan de overheid, terwijl die overheid randvoorwaarden stelt aan de vele deelmarkten waarop die burgers opereren ${ }^{65}$.

Nog een stap verdergaand, kan men ook veronderstellen dat dit gedrag niet los staat van de ontwikkelingen in de sfeer van arbeid zoals de reeds genoemde kennis- en zorgintensivering. Arbeid bestaat behalve uit directe werkzaamheden ook steeds meer uit kennis- en zorgactiviteiten. Die activiteiten strekken zich uit tot kennis van en zorg voor de randvoorwaarden van arbeid, zoals bij dreigende bedrijfssluiting duidelijk naar voren komt; alle 'partijen' trachten zo goed mogelijk op de hoogte te zijn van de politiekbestuurlijke en juridische randvoorwaarden en zij besteden tijd aan 'toezicht' op het proces van vaststelling en handhaving van de randvoorwaarden ${ }^{66}$.

Dit leidt ook tot de paradoxale vaststelling dat op het moment dat de corporatieve structuren aan kracht inboeten, de betrokkenheid van de economie bij de politiek niet behoeft te versmallen, maar eerder groter wordt. Dat dit niet altijd zo wordt gezien, komt doordat de participatie in politieke partijen soms wordt aangezien voor politieke participatie in het algemeen; het dalend ledental van politieke partijen heeft echter te maken met specifieke omstandigheden, zoals afnemende verschillen tussen de partijen, meer verschillen binnen partijen en met een meer staatsinterne gerichtheid van de partijen ${ }^{67}$.

Om misverstanden te voorkomen: het feit dat traditionele corporatieve structuren uiteenvallen, luidt niet automatisch het einde in van belangenorganisaties en van hun relaties met de overheid. Integendeel, in een veranderende omgeving, waar de overheid als geadresseerde onoverzichtelijker wordt door de veelheid van gedeconcentreerde, verzelfstandigde, en geprivatiseerde organen, waar overlegorganen worden opgeheven, en waar adviesorganen louter uit deskundigen worden samengesteld, verandert de functie van nationale maatschappelijke instellingen. Enerzijds krijgen zij meer tot functie om kaders van besluitvorming aan te geven en in stand te houden; bij wijze van tegenwicht tegen de voortdurende dreiging van versnippering van de besluitvorming en tegen de nadelige gevolgen die dit weer heeft voor de effectiviteit en het aanzien van Nederland in internationaal verband. Anderzijds verschuift hun werkzaamheid van overleg naar lobby. Maatschappelijke organisaties bundelen hun krachten (bijv. door fusies) en trachten hun beïnvloedingsactiviteiten op een efficiëntere en professionelere manier vorm te geven. Over het geheel genomen begint het nationale systeem van beleidsbeïnvloeding dan ook meer trekken te vertonen van het stelsel dat bekend is van de Europese Unie en - in een verder verwijderd verband - van de Verenigde Staten ${ }^{68}$. Beziet men ten slotte het geheel van besluitvorming vanuit een internationaal perspectief, dan treden nationale maatschappelijke organisaties vaak tezamen op met nationale overheden, bijvoorbeeld als zij de nationale overheid 'bijstaan' en adviseren in de onderhandelingen in Brussel.

65] Zie over de nieuwe complexiteit in de verhouding overheid-burgers en een relativering van 'het kloofdenken': Herman van Gunsteren en Rudi Andeweg, Het grote ongenoegen, over de kloof tussen burgers en politiek; Haarlem, Aramith, 1994.

${ }^{66}$ ] Over de combineerbaarheid van arbeid met bestuurlijke activiteiten, zie minister Melkert, op. cit..

$\left.{ }^{6}\right]$. Cf. Peter Mair, 'Politieke partijen en hun privileges'; S\&D, nr. 9 , 1995, blz. 395-40l; Voorts F. Becke e.a., 'Over de toekomst van politieke partijen'; Themanummer van Beleid en Mootschoppij, 1995, jrg. 22, nr. 3.

68] In Nederland lijkt de politieke aandacht voor lobbies pas recent op gang te komen, na aanvankelijk geconcentreerd te zijn geweest op adviesorganen; vgl. H. van der Sluijs, en P. den Hoed, 'Adviesstelsel herzien; politiek primaat hersteld?'; Openbaar bestuur, november 1996, blz. 2-9; P.C.M van Schendelen heeft veel over lobbies geschreven, zie van zijn hand o.m. 'De fictie van de formele staat'; Intermediair, 26 juli 1996. 
Deze toekomstverkenning naar 'tweedeling', ofwel naar kansen en gevaren voor maatschappelijke cohesie, heeft een aantal inzichten opgeleverd die zowel voor de beoordeling van actueel beleid als voor de beleidsdiscussie van de toekomst van belang kunnen zijn. Hierbij is verder gegaan dan doorgaans gebeurt op basis van trendmatige cijferreeksen. Gepoogd is op wezenlijke onderdelen iets te zeggen over de toekomst. Dit geschiedde via een combinatie van empirisch waarneembare ontwikkelingen met meer functionalistische beschouwingen over de gevolgen die zulke ontwikkelingen zouden kunnen hebben voor opvattingenstelsels. Het spreekt vanzelf dat deze methode geen grotere waarheidspretentie kan hebben dan andere gebruikelijke manieren om de sociaal-culturele toekomst te verkennen.

\subsubsection{Het dieptepunt van de jaren zeventig en tachtig}

Op basis van empirische gegevens is aannemelijk gemaakt, dat de Nederlandse samenleving vanuit het perspectief van maatschappelijke participatie in de jaren zeventig en tachtig door een diep dal is gegaan. Dat waren de decennia van de grote sociaal-culturele omwenteling, waarin de toestroom van vrouwen naar de arbeidsmarkt serieuze vormen begon aan te nemen op het moment dat de elkaar opvolgende economische crises van 1973 en 1979 het speelveld voor nieuwe ontwikkelingen aanmerkelijk verkleinden. De sociaal-culturele ontwikkeling van grotere verzelfstandiging, onderwijsexpansie en vrouwenemancipatie raakte in een stroomversnelling op het moment, dat de sociaal-economische ontwikkeling van arbeidsmarkt en inkomen dramatisch stagneerde. De gevolgen hiervan waren pijnlijk, ook al drongen ze aanvankelijk niet zo tot de bevolking door. Het stelsel van sociale zekerheid fungeerde voorlopig als adequaat opvangmechanisme en menigeen kon blijven denken dat het daar nu ook precies voor was bedoeld. Per saldo betekende dit een voortgaande verlaging van het arbeidsparticipatiecijfer, een cijfer dat vanwege de sociaal-culturele vanzelfsprekendheid van niet-werkende vrouwen in Nederland toch altijd al laag was geweest. Voorzover vrouwen in die omstandigheden tot de arbeidsmarkt konden toetreden, liep dit gelijk op met een forse uitstroom van mannelijke werknemers, een categorie die, anders dan de instromende vrouwen, wèl op de sociale zekerheid was aangewezen. Kortom: toenemende verzelfstandiging van met name vrouwen en jongeren creëerde een nieuw arbeidsaanbod, dat in een stagnerende economie alleen via uitstoot van andere categorieën - en dat dan nog in beperkte mate - kon worden geaccommodeerd. De sociale druk die hiervan het gevolg was, versterkte de polarisering, die op haar beurt weinig bijdroeg aan een oplossing van deze sociaal-culturele en sociaal-economische problematiek. De nettoparticipatiegraad bereikte in het midden van de jaren tachtig het dieptepunt van 51 procent, nòg lager dan in de periode waarin de non-participatie van het vrouwelijk deel van de bevolking sociaal en cultureel geaccepteerd was. De druk op de sociale zekerheid werd steeds groter. Uitkeringen op basis van de sociale zekerheid groeiden in de dagelijkse praktijk uit tot een 'normale' manier van inkomensverwerving. Desondanks bleef het beleid lange tijd georiënteerd op (herstel van) een situatie die feitelijk al voorbij was. Zeker terugblikkend kan worden vastgesteld dat het sociaal-economische kader de sociaal-culturele ontwikkeling toen zo heeft bekneld dat het zoeken naar schuldigen en zondebokken niet kon uitblijven.

\subsubsection{Het sociaal-economische dieptepunt voorbij}

De ontwikkeling sindsdien toont weliswaar op de belangrijkste sociaal-economische verdelingsdimensies enige (en soms zelfs aanmerkelijke) verbetering, maar intussen is toch de publieke discussie over tweedeling, maatschappelijke ontwrichting en armoede nu goed losgebarsten. 'Armoede' staat weer op 
de politieke agenda 69. Deze paradoxale situatie heeft er vermoedelijk mee te maken dat ter beheersing van de hoge socialezekerheidslasten een beleid is ingezet dat ook de hoogte van de uitkeringen voor diegenen die daar volledig afhankelijk van zijn, naar beneden heeft bijgesteld. Zeker de huishoudens die vele jaren achtereen van een dergelijk minimaal inkomen moeten rondkomen en die tegelijkertijd met toenemende woonlasten worden geconfronteerd, kunnen hierdoor in een situatie van armoede zijn terechtgekomen. Dit wordt onderstreept door recente studies, zoals Arm in Nederland en Het onderste $k$ wart ${ }^{70}$. Dat de verscherping van de armoedeproblematiek een slinkend deel van de bevolking treft ${ }^{71}$, blijkt zowel positief als negatief te duiden. De positieve kant hiervan is dat de economische verbetering blijkbaar ook effect gaat hebben op de onderkant van de arbeidsmarkt. Negatief is dat de achterblijvers in deze ontwikkeling verder op achterstand worden gezet. De suggestie van tweedeling betreft eerder de afstand tussen voorlopers en achterblijvers dan de relatieve omvang van de groep achterblijvers.

De weg vooruit ligt derhalve vooral in een moeilijk maar samenhangend beleid van verruiming van de arbeidsmarkt, gepaard aan beperking van de toegankelijkheid van de sociale zekerheid en versterkte controle op misbruik daarvan. Bij succes hiermee zal het ook niet meer nodig zijn burgers die vanwege zorgverplichtingen, handicaps of onvrijwillige werkloosheid niet in hun eigen onderhoud kunnen voorzien, toch op hun middelen van bestaan te korten. Dit betekent wel dat de overheid het waarborgen van werk hoog in het vaandel moet voeren. Immers, zonder een dergelijke 'waarborg' heeft het weinig zin te onderscheiden tussen diegenen die wel en die niet tot werken in staat zijn.

\subsubsection{Het sociaal-economisch perspectief voor de toekomst: kansen en gevaren voor cohesie}

Naar uit het voorgaande is gebleken, kan het sociaal-economische kader voor maatschappelijke ontwikkeling zich de komende twee decennia relatief gunstig ontwikkelen, waarbij zich de paradox voordoet dat juist zo'n gunstige ontwikkeling tot verscherping van de sociaal-culturele problematiek kan leiden. Dit zou met name kunnen gebeuren als de ingewikkelde interactie van feiten en opvattingen uit het oog wordt verloren. In dat geval kan immers ook geen beleid worden ingezet dat voornoemde dreiging vermag op te heffen.

Over de aard van het probleem hoeft na het voorgaande geen misverstand meer te bestaan. Als het arbeidsparticipatiemotief als grondslag voor maatschappelijke integratie in kracht blijft toenemen, kan het niet anders of degenen die om andere dan legitieme verlofregelingen niet aan het arbeidsproces kunnen deelnemen, zullen dit nog nadrukkelijker dan thans als een vorm van uitsluiting ervaren. Omdat deze gedwongen inactiviteit, exclusiever dan thans reeds het geval is, zal neerslaan bij diegenen die laaggeschoold zijn, zal de frustratie van uitsluiting worden verergerd door het stigma van gebrekkige intellectuele competentie. In de retoriek van de kennisintensivering van de samenleving zou zo een groep kunnen ontstaan die in de visie van de grote meerderheid van de samenleving 'nu eenmaal niet meer kan meekomen'. Daarmee zouden dan belangrijke ingrediënten geleverd zijn voor een situatie die bij het doorzien van deze interactie van feitelijke ontwikkelingen enerzijds en opvattingen anderzijds te voorkomen zou zijn geweest.

69] Vgl. Minister Melkert op de Sociale Conferentie, Zwolle, 31-10-1996. Staatscourant, 31-10-1996, blz. 6.

70] Engbersen e.a., op. cit.; en De Beer, 1996, op. cit.

ㄱ] Ibid. 
Naar de mate dat de emancipatie van arbeid zich in de toekomst zal voortzetten (en dus ook op de onderkant van de arbeidsmarkt effect gaat krijgen, bijvoorbeeld via een grotere vraag naar zorgintensief werk), zal het steeds aantrekkelijker worden een plaats op de arbeidsmarkt te verwerven. De vooruitberekeningen van de werkgelegenheid voor de komende decennia maken het niet onwaarschijnlijk dat het arbeidsaanbod beter kan worden geaccommodeerd dan in de afgelopen twee decennia. Dit geldt in ieder geval voor de hogere en middenregionen van de arbeidsmarkt. Dit betekent echter ook dat onvrijwillige werkloosheid straks nog sterker een probleem van de lagere regionen van de arbeidsmarkt alleen zal worden en dat het weer dezelfde frustratie wordt als in de jaren zeventig, toen de eerste huisvaders uit het arbeidsproces werden gestoten. De sociale isolatie die het gedwongen aan de kant staan met zich meebrengt (en die niet meer zo gemakkelijk als in de jaren vijftig en zestig door de combinatie van gezinstaken en vrijwilligerswerk kan worden opgeheven), zou hierdoor versterkt kunnen worden.

Voor het beleid betekent dit, als gezegd, dat de nieuwe sociaal-economische ontwikkelingen vooral dienen te worden benut voor een versterkte beweging in de richting van de waarborging van werk. Als werk de belangrijkste weg wordt waarlangs de voorwaarden voor sociale integratie kunnen worden gerealiseerd, ligt daar een kerntaak van de overheid. Gaat men ervan uit dat de taak van de overheid als geheel kan worden getypeerd als het mogelijk maken van de samenleving ${ }^{72}$, dan betekende dit voorheen het bieden van een financieel bestaansminimum aan alle burgers; tegenwoordig wordt steeds duidelijker dat alleen de beschikking over financiële middelen van bestaan niet toereikt voor werkelijke maatschappelijke participatie, waardoor waarborging van werk een steeds belangrijker functie van de sociale zekerheid zal worden. Het is zelfs niet onmogelijk dat een dergelijke waarborg de primaire functie van het zekerheidsstelsel van de eenentwintigste eeuw zal worden. Alleen in die gevallen waar de waarborg van werk geen maatschappelijk doel dient (bijv. bij arbeidsongeschiktheid, bij ziekte, bij het verrichten van zorg- en opvoedingstaken, bij studie), zal, bijvoorbeeld via een Algemene Verlofwet, de financiële waarborg voorop moeten blijven staan ${ }^{73}$. In alle andere gevallen is de financiële waarborg - in de letterlijke betekenis van het woord - secundair aan de waarborg van werk. Naar het oordeel van de Raad ligt hier een belangrijk toetsingscriterium voor toekomstig sociaal beleid.

Een tweede gevaar dat ondanks de gunstige toekomstkansen de sociale cohesie van de toekomst kan bedreigen, ligt in de voortgezette implementatie van een verkrampt idee van sociale gelijkheid en menselijke waardigheid. Minder markant aanwezig dan de beweging die hierboven als emancipatie van de arbeid werd gekenschetst, zijn er ook tekenen die wijzen op een voorzichtige emancipatie van talent. Die beweging kreeg haar eerste - categorale - uitdrukkingsvorm toen de aanval op de ongelijke verdeling van onderwijskansen werd ingezet. Ook toen werd echter al onderkend dat er een tijd zou komen, waarin het succes van die aanval zou leiden tot 'gelijke kansen op ongelijkheid', waardoor een meritocratisch accent aan gewicht zou gaan winnen. Met dat laatste probleem heeft men in het recente verleden weinig raad geweten. Veel van de discussies die thans over het onderwijsbestel worden gevoerd, maken duidelijk hoe moeilijk het is compromissen te sluiten tussen de gedachte van onderwijs-op-maat en de gebruikelijke manier om sociale gelijkheid af te meten aan een zo beperkt mogelijke variatiebreedte van onderwijsresultaten.

72] Vgl. WRR-project over kerntaken, hiervoor genoemd.

73] Zie ook de adviesaanvrage (d.d 21 mei 1996) over Arbeid en Zorg (haalbaarheid loopbaanonderbreking) aan de Stichting van de Arbeid en de Raad voor het Overheidspersoneelsbeleid, Tweede Kamer, 24 332, nr. 10 (aanvrage ter inzage bij de afdeling parlementaire documentatie). 
Om alle talent de kans te geven zich maatschappelijk nuttig te maken en op die manier de fundamentele sociale gelijkwaardigheid van mensen te onderstrepen, is het nodig dat al die regelingen worden herzien en afgeschaft, die suggereren dat aan de onderkant van de scholingsmarkt (en dat geldt zeker voor de niveaus 'elementair' en 'basis') geen maatschappelijk relevant of nuttig werk kan worden verricht. De arbeidsintensiteit die bovendien met het creëren van een adequate zorg- of vormingscontext gepaard gaat, zou het mes wat dat betreft aan twee kanten doen snijden.

Beleid zou zich dan ook op deze twee zaken moeten richten. In de eerste plaats moet gehoor worden gegeven aan de ontwikkeling die arbeid en arbeidsdeelname tot hoofdinstrument van maatschappelijke integratie hebben gemaakt ${ }^{74}$. Dit betekent dat de waarborg van werk niet alleen tot kerntaak van de overheid zal uitgroeien, maar tevens de grondslag zal gaan vormen van het stelsel van sociale zekerheid. De consequentie daarvan is weer dat gezocht moet worden naar methoden om het sociale stelsel congruent te maken aan de arbeidsmarkt en aan het stelsel van economische productie. Dat kan vervolgens alleen maar succes hebben als een grote herwaardering van de maatschappelijke functie van talent - en dus ook van laaggeschooldheid - wordt ingezet. Beide 'emancipatiebewegingen' zijn processen van lange adem en zullen vermoedelijk niet meteen in goede aarde vallen. Niettemin zouden zij ook voor de onmiddellijke toekomst de meetlat moeten vormen waarlangs voorgenomen beleid op zijn sociaal-cohesieve potentie kan worden gemeten.

Wat betreft de vraag naar kansen op en gevaren van tweedeling in onze maatschappij, kan ten slotte het volgende worden gezegd: als er in de naoorlogse periode sprake is geweest van tweedeling en grote maatschappelijke druk, dan was dit vooral de jaren zeventig en tachtig het geval. Voor de onmiddellijke toekomst zijn de vooruitzichten betrekkelijk gunstig, vooropgesteld dat het sociaal-economisch en het sociaal-cultureel beleid zich rekenschap geeft van de noodzaak tot de verdere emancipatie van arbeid en de emancipatie van talent. Inzicht in de contextgebondenheid van begripsvorming en morele oordeelsvorming is hierbij van essentieel belang. Dit biedt bovendien de ruimte om in een tijdperk van individualisering de mogelijkheden voor sociale cohesie op waarde te schatten. Onder die voorwaarde biedt de toekomst de maatschappelijke samenhang een gunstig perspectief. 


\section{Rapporten aan de Regering}

\section{Eerste raadsperiode:}

1 Europese Unie*

2 Structuur van de Nederlandse economie*

3 Energiebeleid

Gebundeld in één publikatie (1974)*

Milieubeleid (1974)*

Bevolkingsgroei (1974)*

De organisatie van het openbaar bestuur (1975)*

Buitenlandse invloeden op Nederland: Internationale migratie (1976)*

Buitenlandse invloeden op Nederland:Beschikbaarheid van wetenschappelijke en technische kennis $(1976)^{*}$

Commentaar op de Discussienota Sectorraden (1976)*

Commentaar op de nota Contouren van een toekomstig onderwijsbestel (1976)*

Overzicht externe adviesorganen van de centrale overheid $(1976)^{*}$

Externe adviesorganen van de centrale overheid (1976)*

Maken wij er werk van?Verkenningen omtrent de verhouding tussen actieven en niet-actieven (1977)*

Interne adviesorganen van de centrale overheid (1977)*

De komende vijfentwintig jaar - Een toekomstverkenning voor Nederland (1977)*

16 Over sociale ongelijkheid - Een beleidsgerichte probleemverkenning (1977)*

\section{Tweede raadsperiode:}

17 Etnische minderheden (1979)*

A. Rapport aan de Regering

B. Naar een algemeen etnisch minderhedenbeleid!

Plaats en toekomst van de Nederlandse industrie (1980)*

19 Beleidsgerichte toekomstverkenning

Deell: Een poging tot uitlokking (1980)*

20 Democratie en geweld

Probleemanalyse naar aanleiding van de gebeurtenissen in Amsterdam op 30 april 1980*

Vernieuwingen in het arbeidsbestel (1981)*

Herwaardering van welzijnsbeleid (1982)*

Onder invloed van Duitsland

Een onderzoek naar gevoeligheid en kwetsbaarheid in de betrekkingen tussen Nederland en de Bondsrepubliek $(1982)^{*}$

Samenhangend mediabeleid $(1982)^{*}$

\section{Derde raadsperiode:}

\section{Beleidsgerichte toekomstverkenning}

Deel 2: Een verruiming van perspectief (1983)*

26

Waarborgen voor zekerheid; een nieuw stelsel van sociale zekerheid in hoofdlijnen (1985)

27 Basisvorming in het onderwijs (1986)

28 De onvoltooide Europese integratie (1986)

29 Ruimte voor groei; kansen en bedreigingen voor de Nederlandse economie in de komende tien jaar (1987)

30 Op maat van het midden- en kleinbedrijf (1987)

Deel I: Rapport aan de Regering;

Deel 2: Pre-adviezen

31 Cultuur zonder grenzen (1987)*

32 De financiering van de Europese Gemeenschap; een interimrapport (1987)

33 Activerend arbeidsmarktbeleid (1987)

34 Overheid en toekomstonderzoek; een inventarisatie (1988) 
Een werkend perspectief; arbeidsparticipatie in de jaren '90 (1990)

Technologie en overheid (1990)

De onderwijsverzorging in de toekomst (1991)

Milieubeleid; Strategie, instrumenten en handhaafbaarheid (1992)

Grond voor keuzen; Vier perspectieven voor de landelijke gebieden in de Europese Gemeenschap (1992)

Ouderen voor ouderen; Demografische ontwikkelingen en beleid (1993)

\section{Vijfde raadsperiode:}

Duurzame risico's; Een blijvend gegeven (1994)

Belang en beleid; Naar een verantwoorde uitvoering van de werknemersverzekeringen (1994)

Besluiten over grote projecten (1994)

47 Hoger onderwijs in fasen (1995)

48 Stabiliteit en veiligheid in Europa; het veranderende krachtenveld voor het buitenlands beleid (1995)

49 Orde in het binnenlands bestuur (1995)

50 Tweedeling in perspectief (1996) 


\section{Voorstudies en achtergronden}

\section{Eerste raadsperiode:}

VI W.A.W. van Walstijn e.a.: Kansen op onderwijs; een literatuurstudie over ongelijkheid in het Nederlandse onderwijs $(1975)^{*}$

V2

\section{Nederland}

Studie bij het rapport Plaats en toekomst van de Nederlandse industrie (1980**

\section{* Uitverkocht}



J.C.van Ours: Raming van de finale bestedingen en enkele andere grootheden in Nederland in 1985 Technische nota's bij het rapport Plaats en toekomst van de Nederlandse industrie (1980)*

J.A.H. Bron: Arbeidsaanbod-projecties 1980-2000 (1980)*

P. Thoenes, R.J. In 't Veld, I.Th.M. Snellen, A. Faludi: Benaderingen van planning Vier pre-adviezen over beleidsvorming in het openbaar bestuur (1980**

Beleid en toekomstVerslag van een symposium over het rapport Beleidsgerichte toekomstverkenning deel I $(1981)^{*}$

L.J. van den Bosch, G. van Enckevort, Ria Jaarsma, D.B.P. Kallen, P.N. Karstanje, K.B. Koster: Educatie en welzijn $(|98|)^{*}$

J.C. van Ours, D. Hamersma, G. Hupkes, P.H. Admiraal: Consumptiebeleid voor de werkgelegenheid Pre-adviezen bij het rapport Vernieuwingen in het arbeidsbestel (1982)*

J.C. van Ours, C. Molenaar, J.A.M. Heijke: De wisselwerking tussen schaarsteverhoudingen en beloningsstructuurPre-adviezen bij het rapport Vernieuwingen in het arbeidsbestel (1982)*

A.A. van Duijn, W.H.C. Kerkhoff, L.U. de Sitter, Ch.J. De Wolff, F. Sturmans:Kwaliteit van de arbeid Pre-adviezen bij het rapport Vernieuwingen in het arbeidsbestel $(1982)^{*}$

J.G. Lambooy, P.C.M. Huigsloot en R.E. van de Lustgraaf. Greep op de stad? Een institutionele visie op stedelijke ontwikkeling en de beïnvloedbaarheid daarvan (1982)*

J.C. Hess, F. Wielenga: Duitsland in de Nederlandse pers - altijd een probleem? Drie dagbladen over de Bondsrepubliek 1969-1980 (1982)*

C.W.A.M. van Paridon, E.K. Greup, A. Kerting. De handelsbetrekkingen tussen Nederland en de Bondsrepubliek Duitsland (1982)*

W.A. Smit, G.W.M. Tiemessen, R. Geerts: Ahaus, Lingen en Kalkar; Duitse nucleaire installaties en de gevolgen voor Nederland (1983)*

J.H. von Eije: Geldstromen en inkomensverdeling in de verzorgingsstaat (1982)*

Verslag van de tweede Raadsperiode 1978-1982*

P. den Hoed, W.G.M. Salet en H. van der Sluijs: Planning als onderneming (1983)*

H.F. Munneke e.a.: Organen en rechtspersonen rondom de centrale overheid (1983); 2 delen*

M.C. Brands, H.J.G. Beunders, H.H. Selier: Denkend aan Duitsland; Een essay over moderne Duitse geschiedenis en enige hoofdstukken over de Nederlands-Duitse betrekkingen in de jaren zeventig (1983)*

L.G. Gerrichhauzen: Woningcorporaties; Een beleidsanalyse (1983)*

J. Kassies: Notities over een heroriëntatie van het kunstbeleid (1983)*

Leo Jansen: Sociocratische tendenties in West-Europa $(1983)^{*}$ 
M3 LJ. Heinsman/NOS: De kulturele betekenis van de instroom van buitenlandse televisieprogramma's in Nederland Een literatuurstudie (1982)*

M4 L.P.H. Schoonderwoerd, W.P. Knulst/Sociaal en Cultureel Planbureau: Mediagebruik bij verruiming van het aanbod (1982)*

M5 N. Boerma, J.J. van Cuilenburg, E. Diemer, J.J. Oostenbrink, J. van Putten: De omroep: wet en beleid; een juridischpoliticologische evaluatie van de omroepwet (1982)*

M6 Intomart b.v.: Etherpiraten in Nederland (1982)*

M7 P.J. Kalff/nstituut voor Grafische Techniek TNO: Nieuwe technieken voor produktie en distributie van dagbladen en tijdschriften (1982)*

M8 J.J. van Cuilenburg, D. McQuail: Media en pluriformiteic; Een beoordeling van de stand van zaken (1982)*

M9 K.J. Alsem, M.A. Boorsma, G.J. van Helden, J.C. Hoekstra, P.S.H. Leeflang, H.H.M. Visser: De aanbodstructuur van de periodiek verschijnende pers in Nederland $(1982)^{*}$

M10 W.P. Knulst/Sociaal en Cultureel Planbureau: Mediabeleid en cultuurbeleid; Een studie over de samenhang tussen de twee beleidsvelden $(1982)^{*}$

MII A.P. Bolle: Het gebruik van glasvezelkabel in lokale telecommunicatienetten (1982)*

MI2 P. te Nuyl: Structuur en ontwikkeling van vraag en aanbod op de markt voor televisieprodukties (1982)*

MI3 P.J.M. Wilms/Instituut voor Onderzoek van Overheidsuitgaven: Horen, zien en betalen; Een inventariserende studie naar de toekomstige kosten en bekostiging van de omroep (1982)*

MI4 W.M. de Jong: Informatietechniek in beweging; consequenties en mogelijkheden voor Nederland (1982)*

MI5 J.C. van Ours: Mediaconsumptie; Een analyse van het verleden, een verkenning van de toekomst (1982)*

MI6 J.G. Stappers, A.D. Reijnders, W.A.J. Möller: De werking van massa-media; Een overzicht van inzichten (1983)*

F.J. Schrijver: De invoering van kabeltelevisie in Nederland $(1983)^{*}$ 


\section{Derde raadsperiode:}

G.J. van Driel, C. van Ravenzwaaij, J. Spronk en F.R. Veeneklaas: Grenzen en mogelijkheden van het economisch stelsel in Nederland (1983)*

Adviesorganen in de politieke besluitvorming. Symposiumverslag onder redactie van A.Th. van Delden en J. Kooiman (1983)*

E.W. van Luijk, R.J. de Bruijn: Vrijwilligerswerk tussen betaald en huishoudelijk werk; een verkennende studie op basis van een enquête (1984)

Planning en beleid; verslag van een symposium over de studie Planning als onderneming (1984)

W.J. van der Weijden, H. van der Wal, H.J. de Graaf, N.A. van Brussel, W.J. ter Keurs: Bouwstenen voor een geïntegreerde landbouw $(1984)^{*}$

J.F. Vos, P. de Koning. S. Blom: Onderwijs op de tweesprong; over de inrichting van basisvorming in de eerste fase van het voortgezet onderwijs (1985)*

G. Meester, D. Strijker: Het Europese landbouwbeleid voorbij de scheidslijn van zelfvoorziening (1985)

J. Pelkmans: De interne EG-markt voor industriële produkten (1985)

J.J. Feenstra, K.J.M. Mortelmans: Gedifferentieerde integratie en Gemeenschapsrecht: institutioneel- en materieelrechtelijke aspecten (1985)

T.H.A. van der Voort, M. Beishuizen: Massamedia en basisvorming (1986)

C.A. Adriaansens, H. Priemus: Marges van volkshuisvestingsbeleid (1986)

E.F.L. Smeets. Th.J.N.N. Buis: Leraren over de eerste fase van het voortgezet onderwijs (I986)

J. Moonen: Toepassing van computersystemen in het onderwijs (1986)

A.L. Heinink (red.), H. Riddersma, J. Braaksma: Basisvorming in het buitenland (1986)*

Zelfstandige bestuursorganen; verslag van de studiedag op 12 november 1985 (1986)

Europese integratie in beweging; verslag van een conferentie, gehouden op 16 mei 1986 (1986)

C. de Klein, J. Collaris: Sociale ziektekostenverzekeringen in Europees perspectief (I987)

R.M.A. Jansweijer: Private leefvormen, publieke gevolgen; naar een overheidsbeleid met betrekking tot individualjsering (1987)

De ongelijke verdeling van gezondheid; verslag van een conferentie gehouden op 16-17 maart 1987 (1987)

W.G.M. Salet: Ordening en sturing in het volkshuisvestingsbeleid (1987)

H.G. Eijgenhuijsen, J. Koelewijn, H. Visser: Investeringen en de financiële infrastructuur (1987)

H. van der Sluijs: Ordening en sturing in de ouderenzorg (1988)

Verslag en evaluatie van de derde raadsperiode 1983-1987* 
Vierde raadsperiode:

De maatschappelijke gevolgen van erfelijkheidsonderzoek; Verslag van een conferentie op 16-17 juni 1988 (1988)

H.F.L. Garretsen, H. Raac: Gezondheid in de vier grote steden (1989)

P. de Grauwe e.a.: De Europese Monetaire Integratie: vier visies (1989)

Th. Roelandt, J. Veenman: Allochtonen van school naar werk (1990)

W.H. Leeuwenburgh, P. van den Eeden: Onderwijs in de vier grote steden (1990)

M.W. de Jong, P.A. de Ruijter (red.): Logistiek, infrastructuur en de grote stad (1990)

C.A. Bartels, E.J.J. Roos: Sociaal-economische vernieuwing in grootstedelijke gebieden (1990)

W.J. Dercksen (ed.): The Future of Industrial Relations in Europe; Proceedings of a conference in honour of prof. W. Albeda (1990)

Sociaal-economische gezondheidsverschillen en beleid; preadviezen (1991)

F.J.P.M. Hoefnagel: Cultuurpolitiek: het mogen en moeten (1992)

K.W.H. van Beek, B.M.S. van Praag: Kiezen uit sollicitanten; Concurrentie tussen werkzoekenden zonder baan (1992)

Jeugd in ontwikkeling: Wetenschappelijke inzichten en overheidsbeleid (1992)

A.M.J. Kreukels, W.G.M. Salet (ed.): Debating institutions and Cities; Proceedings of the Anglo Dutch Conference on Urban Regeneration (1992)

H.R. van Gunsteren en P. den Hoed. Burgerschap in praktijken (1992)

F. Bletz, W. Dercksen and K. van Paridon (ed.): Shaping Factors for the Business Environment in the Netherlands after 1992 (1993)

N.T. Bischoff, R.H.G. Jongman: Development of Rural Areas in Europe: The Claim for Nature (1993)

Verslag en evaluatie van de vierde raadsperiode (1993)

F.J.P.M. Hoefnagel m.m.v. H.G.M. Hendriks en M.D. Verdaasdonk: Het Duitse Cultuurbeleid in Europa (1993)

Voorstudies en achtergronden technologiebeleid:

W.M. de Jong: Perspectief in innovatie: de chemische industrie nader beschouwd (199I)

C.L.J. van der Meer, H. Rutten, N.A. Dijkveld Stol/ Nationale Raad voor Landbouwkundig Onderzoek/ Landbouw Economisch Instituut: Technologie in de landbouw: effecten in het verleden en beleidsoverwegingen voor de toekomst (1991)

F.H. Mischgofsky/ Grondmechanica Delft: Overheid en innovatiebevordering in de grond-, water- en wegenbouwsector: een verkenning (1991)

F.M. Roschar (red.), H.L. Jonkers, P. Nijkamp: Meer dan transport alleen: 'veredeling' als overlevingsstrategie (199I)

B. Dankbaar, Th. van Dijk, L. Soete, B. Verspagen/ Maastricht Economic Research Institute on Innovation and Technology: Technologie en wetenschapsbeleid in veranderende economische theorievorming (1991) 
J.M. Roobeek, E. Broesterhuizen: Verschuivingen in het technologiebeleid: een internationale vergelijking vanuit de praktijk (I99I)

T7

H.L. Jonkers, F.M. Roschar: Samenhang in doen en laten; de ontwikkeling van wetenschaps- en technologiebeleid (1991)

\section{Vijfde raadsperiode:}

V82

W.J. Dercksen e.a.: Beroepswijs onderwijs; Ontwikkelingen en dilemma's in de aanstuiting van onderwijs en arbeid (1993)

V83

W.G.M. Salet: Om recht en staat; Een sociologische verkenning van sociale, politieke en rechtsbetrekkingen (1994)

V84

J.M. Bekkering: Private verzekering van sociale risico's (1994)

V85

C. Lambers, D.A. Lubach, M. Scheltema: Versnelling juridische procedures grote projecten (1994)

V86

CSHOB: Aspecten van hoger onderwijs; een internationale inventarisatie (1995)

V87 T. van der Meij e.a.: Ontwikkelingen in de natuur; visies op de levende natuur in de wereld en scenario's voor het behoud daarvan (1995)

L Hagendoorn e.a.: Etnische verhoudingen in Midden- en Oost-Europa (1995)

H.C. Posthumus Meyjes, A. Szász, Christoph Bertram, W.F. van Eekelen: Een gedifferentieerd Europa (1995)

J. Rupnik e.a.: Challenges in the East (1995)

J.P.H. Donner (rapporteur): Europa (1995)

R.M.A. Jansweijer; Gouden bergen, diepe dalen: de inkomensgevolgen van een betaalbare oudedagsvoorziening (1996)

W. Derksen, W.G.M. Salet (red.); Bouwen aan het binnenlands bestuur (1996)

SEO/Intomart: Start-, slaag- en faalkansen van hoger opgeleide startende ondernemers (1996)

L.J. Cunning-Schepers, G.J. Kronjee, R.A. Spasoff (red.); Fundamental questions about the future of health care (1996)

\section{Overige publicaties:}

Voor de eenheid van beleid; Beschouwingen ter gelegenheid van vijftig jaar Ministerie van Algemene Zaken (1987)

Eigentijds burgerschap; WRR-publikatie vervaardigd onder leiding van H.R. van Gunsteren (1992) 